\title{
Development of Retail Payment Systems since 1949
}

By

Michael Wilkinson

A thesis

submitted to the Victoria University of Wellington in fulfilment of the requirements for the degree of Master of Arts

in Economics 


\begin{abstract}
Starting with the introduction of the Diner's Club payment card in 1949, the means of exchange have progressed well beyond traditional instruments such as notes, coins and cheques. I use institutional economics to analyse historical data on the evolution of recently-developed retail payment systems in Australia, Canada, Germany, New Zealand, Norway, the United Kingdom and the United States. The framework I create yields insights into the incentives faced by the users of payment instruments and the payment networks that provide them. It also provides a means to assess the role of government in the evolution of retail payment systems.
\end{abstract}

Ceteris paribus, consumers and merchants will prefer low transaction cost payment instruments. In order to complete a transaction, a consumer will proffer an instrument that may or may not be accepted by the merchant. Together, merchants and consumers will choose the payment instrument that generally reduces demand-side - i.e. consumer and merchant - transaction costs, relative to other available instruments. Consumer irreversible costs of adoption enhance the importance of network effects. To help overcome these, I argue payment networks need to make acceptance of their instrument attractive to merchants, which I find to be supported by analysis of the pricing of payment instruments. It distinguishes recently-developed payment instruments from other new technologies - the most technologically advanced instrument will not likely be adopted unless it is first acceptable to merchants.

In workably competitive conditions, profit-seeking payment networks will attempt to provide an instrument that gets used while it at least recoups its costs of supply from fees paid by users. I argue this suggests a process of institutional adaption for profitseeking payment networks. Network effects mean the use of an instrument grows disproportionately faster, the greater the number of people using it. For instrument 
supply, this means profit-seeking payment networks have an incentive to increase participation. In the presence of potential inter-network competition, a payment network will likely experience greater participation if, ceteris paribus, it offers an instrument that generally reduces demand-side transaction costs to a greater degree than competing networks' instruments and provides it with lower costs of supply.

Governments play two key roles in retail payment system development. First, they can affect the development of systems by how well they protect property rights and enforce contracts. Although this role is performed relatively well in my sample countries, my analysis suggests that the use of recently-developed retail payment systems would fall, substantially, were it not so. Second and more importantly in my sample countries, governments impose restrictions on the freedom of contract for payment networks. If restrictions on this freedom are such that they prevent the trading of property rights, they risk reducing either the demand or the supply of payment instruments. Such restrictions might reduce demand if the instrument that would have been used no longer generally reduces demand-side transaction costs. They might reduce supply in two ways: by impeding payment networks' attempts to offer instruments that reduce these transaction costs or by reducing inter-network competition. In summary, I find that it is government restrictions on the freedom of contract that cause the substantial differences in the use of newly-developed retail payment systems between my sample countries. By risking reducing the supply and demand of retail payment systems, these restrictions may diminish innovation in payments, thereby harming dynamic efficiency. 


\section{Acknowledgements}

I am indebted to a great many people for advice, information, and encouragement throughout the development of this thesis. My supervisors, Prof. Lewis Evans and Dr. John Singleton, have been kind and patient, yet firm and insightful, in the way they have helped me carry out my research. Dr. Bryce Wilkinson, Rob Walker, Prof. Ian Harper, Prof. Neil Quigley and Tim Ng have each reviewed the analysis in significant sections of my thesis and provided great encouragement to me in my research. In spite of this valuable assistance, all errors in this thesis are mine alone. Other special efforts to help me were made by Peter McLeod, Tony Coulston, Dr. David Tripe, Christian Bartsch and Lee Wilkinson. As a small token of my appreciation for all the support I have received, I pledge to do my best to assist other researchers with their work. 


\section{Table of Contents}

Abstract

Acknowledgements

Table of Contents iv

Glossary vi vi vis

1. Introduction 1

$\begin{array}{ll}1.1 \text { Money as a Means of Exchange } & 1\end{array}$

1.2 Focus of my Research 2

1.3 Defining a Retail Payment System 2

1.4 Economics of Retail Payment Systems 4

1.5 Countries Compared 6

1.6 Evidence of Payment Instrument Use 8

1.7 My Research Approach and the Layout of My Thesis 10

2. Literature Review 11

$\begin{array}{lll}2.1 & \text { Recently Developed Retail Payment Systems } & 11\end{array}$

$\begin{array}{lll}2.2 & \text { Substitution between Payment Instruments } & 16\end{array}$

$\begin{array}{lll}2.3 & \text { An Institutional Approach to Retail Payment Systems } & 18\end{array}$

2.4 Institutions of Retail Payment Systems 26

2.5 Focus of my Research 52

3. Important Features of Payment Instruments 53

3.1 Australia 55

3.2 Canada 57

$\begin{array}{lll}3.3 & \text { Germany } & 59\end{array}$

$\begin{array}{lll}3.4 & \text { New Zealand } & 61\end{array}$

3.5 Norway 63

$\begin{array}{lll}3.6 & 65\end{array}$

$\begin{array}{lll}3.7 & \text { United States } & 67\end{array}$

$\begin{array}{lll}3.8 & \text { Observations from my Tables } & 69\end{array}$

4. Historical Reviews of Retail Payment System Development 71

$\begin{array}{lll}4.1 & \text { Australia } & 72\end{array}$

4.1.6 Bibliography for Summaries of Australia 93

4.2 Canada 99

4.2.6 Bibliography for Summaries of Canada 111

$\begin{array}{lll}4.3 & \text { European Union } & 115\end{array}$

4.3.3 Bibliography for Summary of the European Union 118

$\begin{array}{lll}4.4 & \text { Germany } & 119\end{array}$ 
4.4.6 Bibliography for Summaries of Germany 131

$\begin{array}{lll}4.5 & \text { New Zealand } & 135\end{array}$

4.5.6 Bibliography for Summaries of New Zealand 144

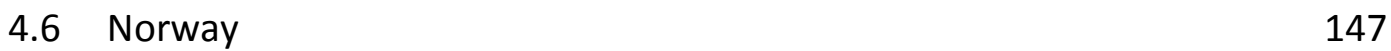

4.6.6 Bibliography for Summaries of Norway 156

$\begin{array}{ll}4.7 & 159\end{array}$

4.7.6 Bibliography for Summaries of the United Kingdom 176

$\begin{array}{lll}4.8 & \text { United States } & 181\end{array}$

4.8.6 Bibliography for Summaries of the United States 200

4.9 Lessons from my Historical Summaries 205

5. Analysis of Retail Payment System Development 217

$\begin{array}{ll}5.1 & \text { Nature of Retail Payment Systems } \\ 5.217\end{array}$

$\begin{array}{lll}5.2 & \text { Demand for Payments Instruments } & 218\end{array}$

5.3 Supply of Instruments by Payment Networks 247

5.4 Retail Payment Systems and Government 257

$\begin{array}{ll}\text { 6. Conclusion } & 281\end{array}$

$\begin{array}{ll}\text { Bibliography for Main Body of Work } & 283\end{array}$ 


\section{Glossary}

$\mathrm{ACH}$

Acquirer

ATM

Card-based

instrument

Consumer-based instrument

Costs of supply

CPSS

CPA

Direct entry

payments

EFTPOS

Automated clearing house

A retail payment system providing instruments for direct entry payments first developed in the US in late 1960s and early 1970s

The financial intermediary of a merchant that acquires transaction information and funds relating to the merchant's use of a particular payment instrument

Automatic teller machine

A payment instrument that is based on a payment card

A payment instrument that does not make formal provisions for acceptance by merchants

The sum of production costs incurred offering an instrument to users and the transaction costs incurred between members of a payment network in the course of producing that instrument.

Committee on Payment and Settlement Systems

Part of the Bank of International Settlements

Canadian Payments Association

Payments initiated between accounts held at financial intermediaries

Electronic Funds Transfer at Point of Sale

The name in some of my sample countries of a debit card system that allows consumers to debit their account by the amount of their purchase using a terminal at the point of sale

ELV

Elektronisches Lastschrift Verfahren

Debit card payment instrument introduced by a merchant in

Germany in 1990 that operates by using a card to generate a direct debit from a customer's to a merchant's account.

ETSL Electronic Transaction Services Limited

A company jointly- owned by New Zealand's banks created in 1989 to operate a debit card payment network

FSA

Financial Services Authority

The UK Government Authority that acquired responsibilities for prudential supervision of the UK's financial industry from the Bank of England in 1997

Giro

A retail payment system providing instruments for direct entry payments significantly developed in Europe in the 1800s 
GZS

Institution

ISL

Issuer

Interchange fee

Mechant-based instrument

MSF

NBFI

Network effect

Network

externality

Payment

instrument

Payment network

Payment scheme

Payments system
Gesellschaft fur Zahlungssysteme

The organisation jointly-owned by Germany's banks created in 1982 to undertake all of Germany's Eurocard issuing and acquiring activities

A system of rules, beliefs, norms and organisations that together generate a regularity of (social) behaviour

Interchange and Settlement Limited

a New Zealand interbank transfer clearing company

The financial intermediary of a consumer that issued that consumer with the particular payment instrument

A wholesale fee internal to a network that is paid between acquirers and issuers, redistributing revenues a network receives from merchants and cardholders

A positive interchange fee is one an acquirer pays to an issuer and a negative interchange fee is one an issuer pays to an acquirer

A payment instrument that that makes formal provisions for acceptance by merchants, c.f. consumer-based instrument

Merchant service fee

A per-transaction fee paid by a merchant upon completion of a transaction made using a particular payment instrument.

Non-bank financial intermediary

The circumstances in which the effect on the net value of an action of the number of agents taking equivalent actions

A specific kind of network effect in which the equilibrium exhibits unexploited gains from trade regarding network participation

Any instrument enabling the holder/user to transfer funds

The group of organisations, as measured by their participation or ownership of assets, that is used to transfer funds for an instrument

An organisation that provides payment networks with a common structure, including rules and wholesale pricing, which networks can use as they provide instruments to users. The two most common payment schemes are Visa and MasterCard

The set of instruments, banking procedures and interbank funds transfer systems which facilitate the circulation of money in a country or in a currency area 
Property right The formal and informal rules that govern access to and use of property (something that can be owned) with key categories including rights to exclude, to determine the use of, to appropriate the income from and to dispose of property

POS Point of sale

RBA Reserve Bank of Australia

Australia's central bank and regulator of the country's retail payment systems

Retail payment system

Self-enforcing institution

SEPA

Store card

Switch fee

TfL

Transaction cost

Two-sided market

Value maximisation principle
A system of payment networks providing the same type of payment instrument, one suitable for retail payments

An individual, taking the institutional structure as a given, finds it best to follow the institutionalised behaviour that, in turn, reproduces the institution in the sense that the implied behaviour confirms the associated beliefs and regenerates the associated norms

Single Euro Payments Area

A self-regulatory initiative set up in 2008 by the European

Payments Council to eliminate differences in national standards for payments

A merchant-specific card which a customer can use for payment at a particular chain of stores or group of stores in the same industry

A fee paid to a payment network operator by one or both of the acquirer and issuer

Transport for London

UK Government entity responsible for London's transport system including the stored-value instrument, the Oyster Card

Costs of exchange between two or more parties that fall into one of three groups: search and information costs, bargaining and decision costs, and policing and enforcement costs

A market will be two-sided if a platform within the market can affect the volume of transactions by charging more to one side of the market and reducing the price paid by the other side

The principle that total transaction value should be maximised and divided among the transaction's participants

Zentraler Kreditausschuss

The central association for Germany's banking system 


\section{Chapter 1 \\ Introduction}

\subsection{Money as a Means of Exchange}

Until the emergence of money, bartering represented the basis for human exchange. As civilisation evolved, money provided three functions: a unit of account, a means of exchange and a store of value. ${ }^{1}$ My thesis focuses on recent developments relating to just one of these functions, the use of money as a means of exchange. Gradually, new payment instruments evolved as substitutes for traditional instruments, such as notes and coins, increasing the convenience and usability of money as a means of exchange.

Money first appeared as objects of value, but, because of coins' convenience as a means of exchange, the kingdom of Lydia developed stamped coins of fixed weights of precious metals in about $600 \mathrm{BC}$ (Evans and Schmalensee, 2005a, p. 26). Eventually, paper money and bills of exchange (commonly known as cheques) also became means of exchange (ibid). Recently, however, there has been a massive increase in the number of ways money can be used as a means of exchange. Much of this change has followed other technological developments, particularly in computing and telecommunications. Cards were already being used for customer identification at some merchants, when, in 1949, Diner's Club introduced a card that could be used for payment by consumers at many different merchants (Stearns, 2007). This change heralded significant new developments of payment instruments or objects used by people to conduct transactions. In their 2003 glossary of payment system terms, the Committee on Payment and Settlement Systems (“CPSS”) define payment instrument as, ”any instrument enabling the holder/user to transfer funds“. A key issue for a payment instrument is, what sort of transactions is it used for? Is it used for smaller value transactions between individuals

1 Evans and Schmalensee (2005a) devote a chapter (Chapter 2) to describe initial developments in the use of money. 
and small businesses completed every day at speed and in high volume or is it used for secure, large value transactions between financial intermediaries? To better understand recent developments of money as a means of exchange, I focus on retail transactions, being of lower unit value and higher aggregate volume than financial wholesale transactions. $^{2}$

\subsection{Focus of my Research}

This thesis assesses the economic factors behind the recent development of retail payment systems. In particular, I seek to answer the question, how have institutional arrangements affected the development of the retail payment systems that have emerged since the creation of the Diner's Club card in 1949? To answer this question, I focus on the emergence and use of new systems in the developed countries, Australia, Canada, Germany, New Zealand, Norway, the United Kingdom (the UK) and the United States (the US).

\subsection{Defining a Retail Payment System}

The European Central Bank (2008) defines the term payment system in two ways; I make use of the first, which refers to a funds transfer system. ${ }^{3}$ This term is defined as, "a formal arrangement based on private contract or law, with multiple membership, common rules and standardised arrangements, for the transmission, clearing, netting and/or settlement of monetary obligations arising between the members." 4 This definition implies the involvement of multiple firms with a retail payment system,

2 While I define a retail payment system (in section 1.3), for the sake of simplicity I chose not to specify that I consider only instruments used for retail payments in my terminology.

3 The second of the paper's two definitions of payment system refers to "the set of instruments, banking procedures and interbank funds transfer systems which facilitate the circulation of money in a country or in a currency area." This definition is commonly used to refer to the banking industry, as a whole, a concept for which I use the term, payments system.

4 Clearing refers to the calculation of organisations' obligations (i.e. the amount banks owe each other) and settling refers to the process of those obligations' settlement. 
which I find to be an important element of those systems. I further restrict the definition by distinguishing between a retail payment system and the payment network $(s)$ that make it up. In subsection 2.4.2, I discuss support for a definition of payment network that refers to the set of participants and ownership of a portfolio of assets. In this way, a retail payment system may be made up of one or more different networks, which may or may not be interoperable, but which provide the same type of payment instrument. For example, Visa and MasterCard (and their issuers and acquirers) are payment networks that are part of the retail payment system that provides credit card instruments.

Payment networks will often consist of financial intermediaries, including both banks and non-bank financial intermediaries (“NBFIs"), but might also consist of other organisations for whom payments systems are important, such as those involved in public transport.

Retail payment systems are distinguished from wholesale payment systems. In their handbook for examinations relating to retail payment systems, the Federal Financial Institutions Examination Council (2004) comments, however, that there is no clear division between the two. Mayes (2006) argues that competition will take place at the margin with wholesale systems, which often use accounts at the central bank, trying to attract larger retail payments and vice versa; however, he admits, "there is no real prospect of very small transactions migrating to the central bank system." Khianarong (2003) takes a different approach, comparing costs arising in the operation of retail and wholesale systems. Because they are used for transactions of higher value, the latter often involve substantial expenditures to improve security and reduce the risk of crime. My focus is on retail payment systems suitable for transactions of lower values. Accordingly, transactions costs are relatively more important and risk mitigation relatively less so. 


\subsection{Economics of Retail Payment Systems}

Kemppainen (2003) discusses reasons why retail payment systems have much in common with network industries, when he investigates the approaches of regulators to systems. The key one, I believe, is that network effects are often present for both. Consistent with Kemppainen's discussion, I use the definition of network effect given by Liebowitz and Margolis (1994), "the circumstances in which the net value of an action ... is affected by the number of agents taking equivalent actions..." Network effects will arise when having another customer changes the value to the existing users of that network. A further complication for understanding the economics of retail payment systems is that systems provide instruments that are part of what Rochet and Tirole described as two-sided markets in their seminal 2003 paper. That is, retail payment systems involve economic activity that links two distinct sets of users that obtain value by interacting over a common platform (in this case, a payment instrument). ${ }^{5}$ Rochet and Tirole (2006a) propose a formal definition:

A market is two-sided if the platform can affect the volume of transactions by charging more to one side of the market and reducing the price paid by the other side by an equal amount; in other words, the price structure matters, and platforms must design it so as to bring both sides on board.

According to Rochet and Tirole's definition, even payment instruments that do not necessarily involve consumers and merchants will still be a two-sided platform if the price structures between the two sides of the market influence the volume of transactions. However, developing countries have experienced the creation of instruments based on mobile phones, which I describe in section 2.1, that allow the transfer of value by text message, but that do not make formal provision for acceptance by merchants. Although instruments such as these have yet to develop in my sample

5 While the term, platform, is in common usage in the literature for two-sided markets, I only use it in connection with this literature and otherwise refer to payment instruments. 
countries, I investigate the extension of my analysis to these and I define payment instruments that make formal provisions for acceptance by merchants as merchantbased instruments. Other payment instruments I refer to as consumer-based instruments.

In order to fully analyse the economics of retail payment systems, I need information on both prices charged for instruments and their amount of usage. I find, however, that data showing both pricing and usage is generally available only for card-based, merchant-based instruments. ${ }^{6}$ While some data on the use of cash exist (such as the amount of cash in circulation), they will also capture its use as a store of value, as well as a medium of exchange. ${ }^{7}$ This makes them inappropriate for comparing cash usage in different countries. Also, I have not found consistent data on the usage of card-based instruments that are not also merchant-based, a key such instrument being a card for use in an automatic teller machine (“ATM"). ${ }^{8}$ However, historical information is generally available on the development of all types of instruments and the payment networks that offer them. For this reason, I focus just on card-based, merchant-based instruments when I use information on the pricing and usage of instruments to analyse payment instrument demand. However, my reliance on historical information allows me to analyse all instruments when I consider their supply by payment networks and of the role of government in the following sections of my thesis.

$6 \quad$ I define a card-based instrument as a payment instrument based on payment card

7 The work of Amromin and Chakravorti (2009), which I discuss in section 2.2, confirms the significance of this issue.

8 A key issue for finding data from official sources for ATM usage is the definitional question of whether the number of ATM transactions should include balance inquiries and deposits, as well as cash withdrawals. 


\subsection{Countries Compared}

In this thesis, I analyse systems in New Zealand, as well as its neighbour, Australia. I also investigate systems in the Canada, the US and the UK. To this sample, I add two other countries, Norway, because it has a particularly well used debit card system, BankAxept, and Germany, because it is a major European country for which reports on retail payment systems are relatively accessible. Table 1.1 provides some key facts for these countries. Payment instruments rely on contracts for the purpose of transferring funds, which makes the enforceability of contracts relevant to the performance of retail payment systems. ${ }^{9}$ For this reason, I have included as background, information about the general, country-wide protection of property rights, during the period for which information is available from the Heritage Foundation's Index of Economic Freedom. ${ }^{10}$

9 The major contracts that newly-developed retail payment systems rely upon are summarised in section 2.1 .

10 In subsection 2.3.1, I describe the definition of property right given by Wilkinson (2008). 
Table 1.1 Key Facts for My Sample Countries

\begin{tabular}{|c|c|c|c|c|c|}
\hline \multirow[t]{2}{*}{ Country } & \multirow{2}{*}{$\begin{array}{c}\begin{array}{c}\text { Population } \\
\text { (million) }\end{array} \\
2008\end{array}$} & \multirow{2}{*}{$\begin{array}{c}\text { GDP Per } \\
\text { Capita } \\
\text { (US\$, PPP) } \\
2008\end{array}$} & \multicolumn{2}{|c|}{$\begin{array}{c}\text { Index Rating for } \\
\text { Property Rights (out } \\
\text { of 100) }\end{array}$} & \multirow{2}{*}{$\begin{array}{c}\text { Currency } \\
2010\end{array}$} \\
\hline & & & 2010 & 1995 & \\
\hline Australia & 21 & $\$ 35,677$ & 90 & 90 & $\begin{array}{l}\text { Australian dollar } \\
\qquad(\mathrm{A} \$)\end{array}$ \\
\hline Canada & 33.3 & $\$ 36,444$ & 90 & 90 & $\begin{array}{l}\text { Canadian dollar } \\
\text { (C\$) }\end{array}$ \\
\hline Germany & 82.1 & $\$ 35,613$ & 90 & 90 & Euro (EUR) \\
\hline New Zealand & 4.3 & $\$ 27,029$ & 95 & $90^{(1)}$ & $\begin{array}{c}\text { New Zealand } \\
\text { dollar (NZ\$) }\end{array}$ \\
\hline Norway & 4.8 & $\$ 58,138$ & 90 & $90^{(1)}$ & $\begin{array}{l}\text { Norsk krone } \\
\text { (NOK) }\end{array}$ \\
\hline $\begin{array}{l}\text { United } \\
\text { Kingdom }\end{array}$ & 61.4 & $\$ 35,445$ & 85 & 90 & Pound sterling $(£)$ \\
\hline United States & 304.1 & $\$ 46,716$ & 85 & 90 & $\begin{array}{l}\text { United States } \\
\text { dollar (US\$) }\end{array}$ \\
\hline
\end{tabular}

Sources: Heritage Foundation (2010) Index of Economic Freedom; Author

(1) Figures for 1996, data for 1995 being unavailable for these countries

To give readers a better understanding of my sample countries relative to other countries, I compare the data in the above table to data for the 183 countries surveyed in the 2010 Index of Economic Freedom. The countries in my sample are sizeable (the least populous of my sample countries, New Zealand, is the $62^{\text {nd }}$ smallest of the surveyed countries), wealthy (relative to an average GDP per capita (US\$ PPP) of US $\$ 14,091$ for the surveyed countries) and have had a strong general level of protection of property rights (relative to an average Property Rights rating for the surveyed countries of 44 in 2010) for the time period for which information from my source is 
available. ${ }^{11}$ All countries operated their own currencies throughout my sample time period with the exception of Germany, which replaced the Deutsche Mark as its legal tender with the official currency of the eurozone, the euro, in 2002.

\subsection{Evidence of Payment Instrument Use}

Figure 1.1 shows data on the use, measured by transaction volume per capita per annum, of two common types of card-based payment instrument, debit cards and credit cards, in each of my sample countries. I have combined transactions made with these instruments because credit cards represent a key source of short term credit in all of my sample's countries, but in two, Norway and Germany, bank account overdrafts also represent a common source and these may be accessed with a debit card. I analyse instrument use for the period of time for which I've found consistent, reliable data for most of my sample countries, being the decade beginning the year 2000 .

11 I relate this general measure to the expectations of a country's citizens that their contracts will be enforced, rather than to specific instances when governments fail to protect property rights. 
Figure 1.1 Average Transaction Volume for Debit and Credit Card Goods

\section{Purchases $^{12}$}

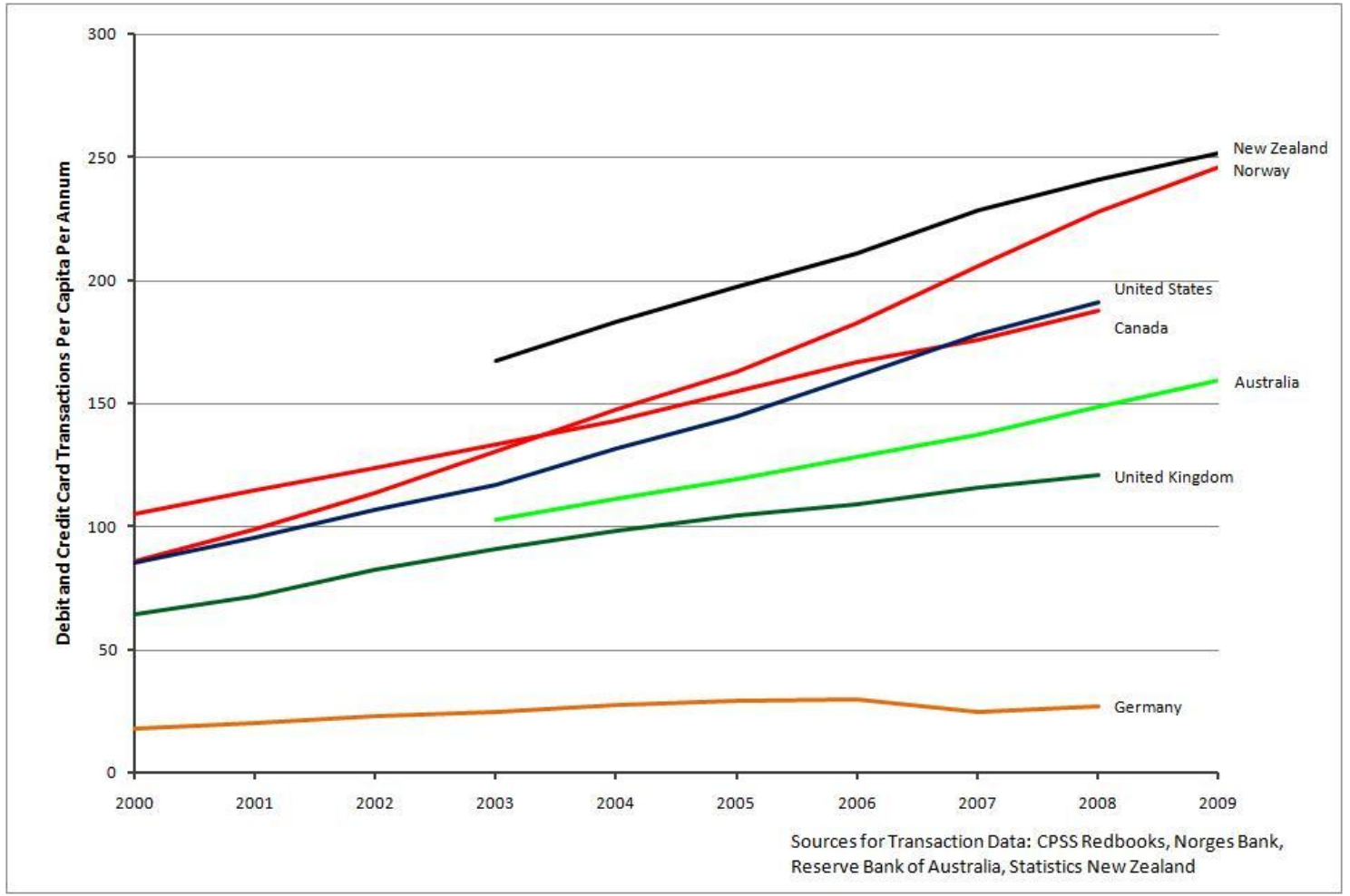

The graph shows a large mix in the amount of adoption of debit and credit cards, as measured by the average volume of transactions per capita, per annum. Among the observations that can be made from it:

- New Zealand and Norway lead the countries in my sample in terms of adoption, but the latter rapidly gaining on the former

- $\quad$ significant differences exist in the growth rates of adoption and

- Germany has a very low adoption of debit and credit cards, relative to the other countries in my sample.

12 My graph does not show any sort of ranking of major users of debit and credit cards around the world. Although I have not completed an exhaustive search, I am aware of one country with particularly well-used cards, Iceland, which, using data from Iceland's central bank, I calculate to have 330 debit and credit card transactions per capita during 2008 (source for transaction data: Sedlabanki Islands [central bank of Iceland], 2010, acquired transactions). However, because of a lack of historical information on the development of its systems, I have not been able to include Iceland in my thesis. 


\subsection{My Research Approach and the Layout of My Thesis}

In this thesis, I consider literature on the development of retail payment systems in Chapter 2, using it to indicate what features of instruments are important to that development. In Chapter 3, I consider the features, particularly the pricing and usage, of major card-based, merchant-based instruments in my sample countries, features that my literature review indicates are important. I turn to a historical analysis of the development of systems, consisting of networks offering all types of instruments in Chapter 4. In Chapter 5, I analyse this development before concluding my thesis in Chapter 6. 


\section{Chapter 2}

\section{Literature Review}

In spite of significant developments in the second half of the twentieth century, retail payment systems have only received significant academic attention recently. This Chapter describes the work I seek to build on in my thesis. In their survey of the literature, Scholnick, Massoud, Saunders, Carbo-Valverde and Rodriguez-Fernandez (2008, p. 1486) say that literature relating just to credit cards, debit cards and ATMs is "not only large and growing, it is also remarkably diffuse." For this reason, I introduce a framework to help me investigate the literature. Firstly, in section 2.1, I describe the payment instruments that have been developed since 1949 before discussing substitutability between those instruments, as well as others developed earlier, in section 2.2. Given this variety of instruments and systems, I use section 2.3 to explain the method of analysis, particularly the framework of institutional change, that I use to investigate retail payment system development. In section 2.4 , I describe the diverse literature providing analysis of retail payment systems useful to my institutional perspective. Finally, I describe the focus of my research on retail payment systems in section 2.5.

\subsection{Recently Developed Retail Payment Systems}

As I mentioned in section 1.1, the development of retail payment systems has followed developments in other technologies, particularly in computing and telecommunications. The ideas behind some recently-developed payment systems can be traced further back in time. Using a card for payment was suggested late in the $19^{\text {th }}$ century and a number of retail chains experimented with what I call a store card, a merchant-specific card which a customer can use for payment at a particular chain of stores or group of stores in the same industry (Evans and Schmalensee, 2005a, p. 53). The telegraph company, 
Western Union, issued what is believed to be the first consumer charge card, a small rectangular piece of paper, in 1914 (Stearns, 2007, p. 32). Indeed, Stearns has sufficient data to plot (pp. 32-35) the development of store cards in the department store, oil and airline industries in the US through the first half of the $20^{\text {th }}$ century. In 1949, Diner's Club introduced the first payment card that could be used by consumers at many different retailers (Stearns, 2007, p. 36). This system operated in a similar way to retail chain store cards, but with merchants choosing whether or not to accept the card. The operator of the payment network maintained contractual relationships with both the consumer and the merchant, with such networks coming to be labelled three-party networks. ${ }^{1}$ Similar networks to the Diner's Club card followed, a particularly important one being American Express.

Given the payment card often involved the provision of funds, it seems natural that banks would have a strong interest in their development. Baxter (1983) describes how a Californian bank, Bank of America, created a four-party credit card networks in 1966 when it started licensing its BankAmericard credit card program to other banks. In this new approach to card payments, transactions would be completed even if the purchaser and the merchant used different banks. With such networks, the four parties are the consumer, the consumer's financial intermediary that issued that consumer with the particular payment instrument ("the issuer"), the merchant and the merchant's financial intermediary that acquires transaction information and funds relating to the merchant's use of a particular payment instrument ("the acquirer"). ${ }^{2}$ As their name suggests, credit cards provide their holders with a line of credit with balances being repaid periodically and any outstanding amounts incurring interest. Some payment cards need to have their

\footnotetext{
Such networks stand distinct from four-party card networks, which I describe in the next paragraph. Contractual relationships exist between the consumer and the issuer, the merchant and the acquirer and between the issuer and the acquirer. The ownership and control of the network is not generally obvious for four-party networks.
} 
balances fully re-paid on a regular basis, an approach commonly used by three-party networks such as American Express and Diners Club. These cards are known as charge cards or deferred or delayed debit cards. However, three-party networks also provided cards to consumers that offered credit, as well, such as American Express's Optima card (Evans and Schmalensee, 2005a, p. 13). ${ }^{3}$ Furthermore, American Express announced it was seeking banking partners to issue its cards in 1997 demonstrating that a three-party network could still have the activity of card issuing performed by other financial organisations (ibid, p. 184).

Other payment instruments were created to provide more direct links with purchasers' accounts. In 1967, arguably the world's first modern ATM was installed in the UK, allowing bank customers to access their accounts and withdraw banknotes using a card with a magnetic strip (Bátiz-Lazo, 2009, p. 6). Hayashi, Sullivan and Weiner (2003, p. 13) note that stores experimented by installing ATMs on their premises before one chain introduced a debit card system in 1976 that allowed cardholders to directly debit their account by the amount of their purchase using a terminal at the point of sale (“POS"). In my sample countries, such systems are sometimes called, Electronic Funds Transfer at Point of Sale ("EFTPOS”). This saved consumers having to withdraw a suitable amount of cash before using it to complete a transaction.

Van Hove (2004) discusses another card-based retail payment system similar to a debit card that I refer to as, a stored value card. ${ }^{4}$ This type of system involves rechargeable cards, which can be used relatively easily for lower value transactions because transactions can occur without contact between a consumer's card and a merchant's

3 I note that there is nothing to prevent four-party schemes offering charge cards, either, although I have not found evidence showing a significant amount of this has occurred.

4 In its glossary of payments system terms, the Committee on Payment and Settlement Systems (2003) defines a stored-value card as, "a prepaid card in which the record of funds can be increased as well as decreased." Because of its greater lucidity, I rely on this term, but note that others, such as Van Hove, use the terms, electronic purse and e-money, to describe the similar instruments. 
terminal; this means that stored-value transactions are often called, "contactless." Van Hove provides data for 16 European networks with the earliest roll-out (of Denmark's Danmønt system) occurring in March 1993. Ives and Earl (1997) describe the development by UK banks of the Mondex stored-value network, which began its first trial in Swindon, UK, in 1995 and was subsequently licensed to banks around the world. Van Hove (2006) points to stored-value cards being used as ticketing system for public transport in an increasing number of countries including Hong Kong, Singapore, Japan,

In many countries, direct links with consumers' bank accounts have grown from the automation of existing paper-based payment instruments. ${ }^{5}$ Evans and Schmalensee (2005a, p. 43) give the example of the giro, a consolidated account-to-account payment instrument significantly developed in Europe in the $1800 \mathrm{~s} .{ }^{6}$ A giro credit differs from a cheque in that payers pay an amount directly into a recipient's account rather than writing a cheque for that amount for the recipient to cash; however, a giro debit is more similar to a cheque, in that it involves the payer authorising the payee to deduct a certain amount from the payer's account. In Europe, giros made the shift from paper to electronic form in the late 1960s and early 1970s, at around the same time that American banks responded to a rapid increase in cheque volumes by forming Automated Clearing Houses (“ACH”) to process account-to-account retail payments electronically (Electronic Payments Network, 2004, p. 1). Giro and ACH credits and debits fall into a category of payments known in Australasia as, direct entry payments,

5 There is little clarity about when the automation of existing instruments results in the introduction of a new instrument. For this thesis, I focus on developments that involve the experiences of the users of an instrument being materially different to before the automation. By this standard, I do not consider developments such as the US Federal Government's Check Clearing for the 21st Century Act enacted in 2003. The Act merely provided for the electronification by merchants of chequest that had already been received from consumers.

6 Although the giro has became significantly more popular as a payment instrument at that time, Davies and Davies (1999) say that a giro system functioned using state granaries as banks in the empire of the Ptolemies in Egypt as early as the $4{ }^{\text {th }}$ Century BC. This suggests giros developed substantially earlier than did cheques, which Evans and Schmalensee (2005a, p. 28) say was developed in northern Italy around the $12^{\text {th }}$ Century. 
being payments initiated between accounts held at financial intermediaries (Australian Payments Clearing Association, 2009, p. 3; Reserve Bank of New Zealand, 2003, p. 7), the term I use to classify all such payments. I also use the term, direct entry payment, to classify those made using networks like Paypal. Evans and Schmalensee (2005a, pp. 307-308) describe the development of direct entry payments made using Paypal, which was acquired and significantly promoted by online auction company eBay in 2002. Shy (2010, p. 24) reports that Paypal is the one successful development of direct entry electronic payments in the US "over the years".

Consumer-based instruments look likely to become more important to retail payment system development in my sample of developed countries. Starting with M-PESA in Kenya in 2007, a number of developing countries have seen the creations of networks offering instruments that transfer value from one mobile phone to another through a text message (Jack and Suri, 2010). Jack and Suri link M-PESA's success to a significant proportion of Kenya's population being without easy access to a bank account. They give some details of the system, reporting (p. 7) that payers are charged flat fees of approximately US $\$ 0.40$ while payees do not incur fees, except when withdrawing money from their M-PESA account. Nyaoma (2009) reports that some small businesses use M-PESA for payment, in spite of the system having no formal provision for merchants. Additionally, Bradford and Hayashi (2007) describe developments of mobile phone-based payment instruments that allow contactless POS payments in Japan and Korea, although importantly they describe such developments as yet to occur in the US. That mobile phone-based instruments have yet to develop in the countries in my sample makes them beyond the scope of my thesis. Nevertheless, I hope the insights from my thesis will be useful as these instruments develop in my sample countries. 


\subsection{Substitution between Payment Instruments}

By analysing the change in transactional demand for cash resulting from greater usage of debit cards in 13 countries from 1988 to 2003, Amromin and Chakravorti (2009) show that debit card use reduces demand for low denomination notes and coins. ${ }^{7}$ They suggest that this is because these denominations are most useful for completing transactions at the POS, while high denomination notes are used for non-transactional purposes such as being a store of value. Furthermore, they discuss how significant amounts of some currencies, principally the US dollar and the Euro, are held outside their country of origin. These two ideas indicate difficulties of using currency stocks to assess the use of a country's non-cash retail payment systems. While Figure 1.1 might provide a comparison of the use of debit and credit cards in my sample countries, the use of cash as a store of value suggests a comparison with the use of cash would be inappropriate for comparing countries' use of newly-developed retail payment systems, in spite of Amromin and Chakravorti (2009) suggesting that there would be substitution between these payment instruments. Humphrey, Pulley and Vesala (1996) analyse the adoption of noncash payment methods in 14 developed countries for the period 1987 to 1993. Consistent with Amromin and Chakravorti, they find a negative relationship between per capita cash holdings and the number of non-cash transactions per capita in only 8 of those countries. Although they say that trends in the use of non-cash payment instruments are complex, Humphrey et al describe the trend from cash to non-cash instruments as "unmistakeable". In their analysis of consumer payment instrument decisions, Scholnick et al (2008) provide evidence on the substitutability of cash and debit cards by looking at the relationship between debit card and ATM transactions. They consider bank level data from Spain for the period, 1997-2003, and find that debit

7 They segment low denomination from high denomination bank notes by referring to what is generally available from ATMs. 
card transactions at POS and ATM transactions are substitutes by showing that ATM surcharges increase debit card POS volume significantly.

While these papers show substitutability between cash and non-cash payment instruments, they provide little evidence of substitution between non-cash instruments. Two key instruments, the usage of which I compare in Figure 1.1 for the countries in my sample, are debit and credit cards. Zinman (2009) arguing there is strong substitution between these two when he models payment card use in 4,000 US households between 1995 and 2004. He finds $38 \%$ of debit card use occurs as consumers choose debit to minimise the cost of transactions because choosing credit would raise such costs for consumers who already revolve debt, face a binding credit limit constraint or lack a credit card. For those consumers not facing credit charges, Zinman suggests (p. 365) paying by debit card offers greater time savings because of no requirement to regularly repay balances. ${ }^{8}$ I refer to this point again in my analysis in subsection 5.2.1. Zinman also cites evidence suggesting credit and debit cards are becoming stronger substitutes over time. Supporting Zinman's conclusions, Klee (2006) finds debit cards are strong substitutes for credit cards when she analyses family level data for 1995 - 2001 from the US Survey of Consumer Finances. She finds a significant rise in multihoming (whereby families hold both debit and credit cards), but describes how debit cards are more likely to be used by families with outstanding balances on their credit cards. Lee and Kwon (2002) use data from the 1998 US Survey of Consumer Finances and assess substitutability between store cards and credit cards. ${ }^{9}$ As well as finding a negative relationship between consumers' credit card usage and their use of store cards for transaction purposes, they find credit availability through

$8 \quad$ While this cost might be thought of as being independent of the size of a credit card bill, I do not believe they will completely be so since repaying a larger regular bill may be more difficult for a consumer than a smaller bill.

9 Lee and Kwon do not appear to compare the relative use of debit cards with store cards. 
bankcards is negatively correlated with consumers' use of store cards as a financing medium, suggesting the role of store cards as a supplementary credit line.

Van Hove (2004) considers the advantages of European stored-value retail payment systems. He argues that stored-value networks may offer instruments that operate with significantly lower costs for merchants than debit cards because stored-value instruments do not require real-time connection with a central computer. However, he refers (pp. 31-32) to a lack of success for these systems in countries where debit cards are suitable for low value transactions and points out (p. 32) that a 2001 Internet survey conducted in Europe found that a "resounding" $84 \%$ of respondents answered the question, "Would you rather see that the credit/debit card were easier to use on small values?", affirmatively.

The substitution between the giro (in paper and electronic form) and the cheque and $\mathrm{ACH}$ also seems unmistakeable. When they investigate cashless payment instrument infrastructure in European countries, Kemppainen and Salo (2006, p. 9) divide countries into two groups, giro countries and cheque countries, in order to assess path dependence in infrastructure. I interpret this to imply that cheques and giros are substitutable as payment instruments, although they will not be perfectly substitutable. It seems obvious to conclude that their electronic, direct entry equivalents, $\mathrm{ACH}$ and electronic giros, are also substitutable.

\subsection{An Institutional Approach to Retail Payment Systems}

In section 1.3, I referred to a definition of retail payment system that implied the involvement of multiple firms. Two questions follow naturally from it, what firms are these and how do they arrange themselves? Moreover, because of my focus on retail payment system development, I also ask, how do these arrangements change over time? 
In his study of medieval trade, Greif (2006) introduces a framework I use for analysing these questions; one based on the analysis of institutions. With Greif's framework in mind, I discuss literature relating to specific influences on institutional design in subsection 2.3.1.

Greif defines (p. 30) an institution as, "a system of rules, beliefs, norms and organisations that together generate a regularity of (social) behavior" and his framework focuses on a transaction as the base unit of analysis and promotes analysing the motivations or incentives of the actors that are party to it. While other researchers have approached institutions as being exogenous, Greif employs game theory analysis to show that the medieval institutions he studies are in fact endogenous: individuals respond to the behaviour and expected behaviour of others and, in doing so, form regularities of behaviour, which leads to the formation of institutions. In this way, institutions can become self-enforcing, which Greif defines as, “... each individual, taking the structure as a given, finds it best to follow the institutionalized behavior that, in turn, reproduces the institution in the sense that the implied behavior confirms the associated beliefs and regenerates the associated norms." While it is tempting to study self-enforcing institutions as equilibria, Greif argues that studying them in this way goes against the concept of endogenous institutional change: it implies that all institutional change must have an exogenous origin, which he finds to be unsatisfactory.

Furthermore, Greif argues many tools of economics suitable for the study of equilibria, such as the game theory he uses, commonly predict multiple institutions will be selfenforcing.

Greif (2006) attempts to resolve these problems by describing at length what he calls the "fundamental asymmetry" or preference for institutions that have been used, previously, to help people predict the actions of those around them when they are 
confronted with unfamiliar situations. ${ }^{10}$ This suggests the worth of using an historical, context-specific analysis of institutions as a framework to study institutional change, which should include analysis of the parameters influencing behaviour. Greif argues (p. 16) that such an approach has advantages not available from alternative methods of studying equilibria:

Studying institutions as equilibrium phenomena, while making explicit, as is done here, the forces rendering them self-enforcing, exposes the exogenous shocks that will lead to institutional failure - specifically, the shocks that cause an institution to be no longer self-enforcing. But the perspective advanced here achieves more than that. It enables us to study institutional dynamics as a historical process. Institutions can remain stable in a changing environment and can change in the absence of environmental change, while past institutions - even those that are no longer self-enforcing - can influence the details of subsequent ones.

This is not to rule out other analytical methods being important: Greif argues (p. 7) that the study of the impact, persistence and change of institutions relies on understanding the parameters faced by actors, for which alternative forms of analysis may be indispensible. Based on this work, I investigate the development of retail payment systems using a historical analysis of institutions that relies on microeconomic theory for understanding the parameters associated with such systems. I seek to identify institutions relevant to retail payment system development by understanding reasons for regularities of behaviour through recent history of my sample countries. As further support for my approach, I cite the work of Hayashi and Weiner (2006) who investigate the practical use of analytical models of payment networks. They compare each model's assumptions and predictions with observations of debit and credit card systems in the US, the UK and Australia, finding that the models are limited in their application and predictive power. They argue this is because of the importance of "country-specific

10 Greif (2006, pp. 164-166) argues that underpinning the fundamental asymmetry are actors' need to economise on knowledge, attention and cognitive resources, as well as obtain value from coordinating their actions with, and therefore predict, the actions of others. 
factors", which I take to indicate a historical, context-specific approach represents a better method of analysis.

While Greif's framework provides a method for analysing how institutions develop, it does not specifically analyse factors in institutional design relevant to retail payment systems. I turn to literature on this subject below.

\subsubsection{Institutional Design}

Milgrom and Roberts (1992) analyse the design of economic organisations and argue a key goal in that task is efficiency: they quote (p. 19) economist Frank Knight, when they say, "\{people\} in general, and within limits, wish to behave economically, to make their activities and their organization "efficient" rather than wasteful." Milgrom and Roberts discuss efficiency with respect to the value maximisation principle, which holds that efficient allocations are those that maximise total transaction value and divide it among the transaction's participants. The principle requires the assumption that there are no wealth effects, an assumption I also make in my thesis. Consistent with that assumption and with the value maximisation principle, I do not analyse how payment networks apportion the profit they make in this thesis. Instead, I consider the question of what is efficiency in relation to institutions before describing literature on two influences on an institution's efficiency.

\section{Institutions and dynamic efficiency}

Evans and Hahn (2010) distinguish the concept of dynamic efficiency from that of static (allocative and productive) efficiency, arguing that the former represents the appropriate standard for the regulation of industries experiencing technological change. They call for regulation to maintain the incentives for dynamic efficiency, indicating the sense of seeing efficiency as a concept that an industry is encouraged to work towards, rather than to be at, at any point in time. In so arguing, they call for the application of antitrust 
regulation to dynamic industries, rather than industry-specific regulation, as a superior method of dynamic efficiency maximisation.

In connection with the dynamic efficiency of the institutions supporting medieval trade, Greif (2006, pp. 397-398) argues that European institutions based on individualism, corporatism and self-governance are more conducive to efficiency than their Muslim counterparts. He uses the concept of adaptive efficiency, implying it is an element of dynamic efficiency, and argues that, by having institutions more adaptive to changing circumstances, citizens of the European world benefited more than their Muslim neighbours because their institutions were more adaptive to a changing world. ${ }^{11}$

\section{Institutions and transaction costs}

Milgrom and Roberts (1992) outline a key motivation for efficient design of organisations, economising on transaction costs. Transaction costs will have an importance both in the decision to use a payment instrument as well as the structuring of the payment network offering it. Because of the importance of transaction costs to both instrument usage and network structuring, I start by describing my basis in the literature for defining such costs. I use the definition provided by Dahlman (1979) that transaction costs are costs of exchange between two or more parties that fall into one of three groups: search and information costs, bargaining and decision costs, and policing and enforcement costs. ${ }^{12}$ Some researchers, such as Kasper and Streit (1998), reserve the term, transaction cost, to describe the costs of transacting across a market and use

11 As one example of the greater adaption to changing circumstances shown by the institutions of Europe, Greif (2006, pp. 205-206) analyses slavery, which was abandoned in the Western World around the mid-nineteenth century because, he argues, slavery proved less efficient than freer labour and enterprise for encouraging production and innovation. In contrast, slavery continued in many Muslim countries until after World War II because, Greif argues, incumbent institutions there were less tolerant of contrary individual behaviour.

12 Although they focus just on market transactions, Kasper and Streit (1991, p. 129) also define transaction costs as the costs of exchanging property rights. I find this approach insufficiently restrictive to be helpful, although I do discuss literature below showing a relationship between property right and transaction costs later in this subsection, 
the term, coordination cost, to describe the costs of exchange for all transactions. I see no reason to distinguish transactions that occur in a market and thus refer to transaction costs simply as the costs of exchange between two or more parties.

In terms of the structuring of payment networks, transaction cost analysis may play a key role in understanding the ways payment networks are structured. Ronald Coase developed a guide for understanding the use of different governance structures to coordinate activities, starting with a 1937 paper investigating the decision to coordinate an activity within a firm or obtain it from another firm. Coase's guide centres on economising on transaction costs. Coase (1988) explains how economising on transaction costs plays a key role in determining whether a good or service is provided within a firm or obtained from another firm (p. 19): "[t]he limit to the size of the firm would be set when the scope of its operations had expanded to the point at which the costs of organizing additional transactions within the firm exceeded the costs of carrying out the same transactions through the market or in another firm." Cheung (1969) extends Coase's transaction cost framework to contracts by building on an analysis of property rights and sharecropping in an earlier paper (Cheung, 1968) to show that economising on transaction costs is important to landowners' and tenants' choices of contractual arrangements.

Williamson (1979) responds to criticisms that almost anything can be rationalised with reference to suitably specified transaction costs by outlining three dimensions that characterise a transaction, as the unit of analysis, when transaction costs can be thought to influence the governance structure used for the transaction:

- $\quad$ asset specificity, which can create costs associated with hold-up during contract execution 
- $\quad$ uncertainty, which reduce parties' ability to write fully contingent claims contracts and

- $\quad$ irregular transactional activity, which reduces the ability of firms to rely on reputation to constraint behaviour.

Each of these dimensions mean transaction cost minimisation makes it more likely an activity is performed within a single firm rather than obtained by one firm from another using a contract. However, in a 1985 book, Williamson spends a chapter (Chapter 6) describing the limits to a firm and why every activity in an economy is not coordinated within a single firm. He summarises the issue (p. 161):

... the transfer of a transaction out of the market into the firm is regularly attended by an impairment of incentives. It is especially severe in circumstances where innovation (and rewards for innovation) are important.

In spite of their relevance to organisational design of payment networks, transaction costs are unlikely to play a supreme role. Milgrom and Roberts (1992, pp. 33-34) highlight that transaction costs are sometimes, but not always, logically distinct from production costs, being the costs of the inputs involved in a production process. Additionally, they argue that it is not obvious efficient organisations will minimise transaction costs. While Milgrom and Roberts admit a "standard answer" to this question is that competition forces transaction cost minimisation, they suggest that making assumptions about competition reduces the applicability of transaction cost theory. However, the apparent relevance of the work on transaction cost economics I described above, particularly Williamson $(1979 ; 1985)$, means I find it difficult to dismiss transaction costs out of hand. Instead, I pay careful attention to the roles of distinctions between production costs and transaction costs in retail payment system prices and of competition in transaction cost minimisation in payment network 
operations. Additionally, I consider other factors, besides transaction costs, that the literature indicates are important to institutional design.

\section{Institutions, transaction costs and property rights}

Coase (1960) analyses arguments of English judges about the costs and benefits of different assignments of rights to help them decide on cases of negligence. He argues that these occurrences show a consciousness of the incidence of property rights influencing the level of transaction costs and of the need to solve the economic problem, which he describes as maximising the value of production. Stigler (1972) builds on this work to describe the Coase Theorem, which he outlines as holding that, in a world of zero transaction costs, the assignment of property rights would not affect the value of production. Given transaction costs do in fact matter and they will be affected by the assignment of property rights, it follows that the incidence of property rights may play an important role in retail payment system development.

Since I pay attention to property rights, I investigate literature regarding their nature and determination. In his analysis of property rights and government takings, Wilkinson (2008) reports that property is generally thought of as something that is owned or possessed to the exclusion of others. Property rights are the formal and informal rules that govern access to and use of property with key categories including rights to exclude, to determine the use of, to appropriate the income from and to dispose of property. I distinguish property rights from the freedom to contract over the transfer of property rights (Trebilcock, 1993, pp. 9-10).

\section{Institutions and other factors - network effects}

In addition to transaction costs, the literature indicates that other factors will play a role in institutional design. For example, the work of Cheung (1969), which I introduced 
above, shows that the allocation of risk plays a part in landowners' and tenants' choices of contractual arrangements, in addition to transaction costs. While risk and numerous other factors may play a role in institutional analysis, but I limit consideration to factors I feel are most relevant to retail payment systems.

Liebowitz and Margolis (1994) outline the importance of network effects relating to the adoption of new technologies: users are more likely to adopt the network those around them are adopting. I use their definition of network effect in preference to their definition of the term, network externality: "a specific kind of network effect in which the equilibrium exhibits unexploited gains from trade regarding network participation." Liebowitz and Margolis find "scant" evidence of the existence of network externalities and caution about their rapid adoption as a basis for (interventionist) public policy towards industries. Accordingly, I avoid the term, network externality, in order not to confuse its use with the term, network effect. Economics literature indicates that network effects raise the importance of a network's decisions about how to behave towards other networks. For example, Katz and Shapiro (1994) point to the role of user expectations of other users' actions in shaping network adoption decisions, thereby indicating that network effects raise the importance of coordination and compatibility in network decisions.

\subsection{Institutions of Retail Payment Systems}

Although I placed some limits on the way I analyse retail payment systems in the previous section, a large amount of literature remains relevant to my thesis and I survey it in this section. I start by surveying the literature analysing the choices of payment instruments made by consumers and merchants in subsection 2.4.1, including literature indicating the importance of network effects to payment instruments. In subsection 2.4.2, I turn to literature covering institutions and payment networks and analyse 
literature on the role of government in retail payment systems in subsection 2.4.3. Finally, I review the literature on how to measure the amount of card-based payment instrument adoption by merchants and consumers in subsection 2.4.4.

\subsubsection{Institutions and Payment Instrument Adoption}

\section{Adoption and instrument attributes}

Rochet and Tirole (2003) describe the fundamental role of platforms in two-sided markets as reducing transaction costs by helping users on each side of a platform interact. Competition between platforms will occur over methods of lowering transactions costs that also help to make participation in the platform attractive to both of the two groups of users or, as Rochet and Tirole put it, to bring both sides onboard. I turn to Rochet and Tirole's conclusions about the prices chosen by two-sided platforms in subsection 2.4.2, but focus here on user adoption decisions. In regard to these decisions, there appear to be a variety of causes of transaction costs. Bolt, Humphrey and Uittenbogaarda (2008) compare the adoption of new payment instruments between 1990 and 2004 in Norway, which has a system of explicitly charging consumers for the costs of different transactions, and the Netherlands, which has no similar pricing system. They find that both countries have rapidly adopted electronic instruments in spite of their different approaches to consumer pricing. They attribute this to lower (although non-priced) transactions costs associated with electronic payment systems. However, they do find that Norway's system of explicit pricing has accelerated the shift to electronic payment systems by approximately 20 percent, relative to that shift in the Netherlands. ${ }^{13}$ Because explicit pricing only accelerated the rate of this shift by approximately one fifth, I interpret this to show that other factors are also important. This indicates that payment instruments are differentiated products. To analyse choices,

13 They measure adoption in terms of average, annual number of transactions per person. 
I find helpful the decision framework proposed by Rosen (1974). According to it, a differentiated product has a vector of implicit or "hedonic" prices that reflects the specific amounts of characteristics associated with it. Users will choose the best product in accordance with their assessment of these prices and their valuation of the attributes as a whole.

Two papers analyse the causes of transaction costs for users of payment instruments. Borzekowski, Kiser and Ahmed (2008) analyse a 2004 survey of debit card use by Michigan consumers and note the importance of six factors to the decision of whether to use cash, a cheque, a debit or credit card to complete a transaction:

- $\quad$ time (a preference for fast transaction processing at, for example, the checkout counter)

- convenience

- $\quad$ money (a pecuniary motive such as avoiding interest payments or fees, using the float, or seeking airline miles or cash rewards points)

- $\quad$ restraint (a desire to limit overspending)

- $\quad$ tracking (ability to track and record purchases)

- $\quad$ acceptance (acceptance of the payment method by retailers).

In her summary of research on consumers' payment instrument choice, Schreft (2006) mentions another attribute likely to be important to consumers is their ability to use one instrument, credit cards, to smooth their consumption over time. Because of this important point, I add to the attributes, the liquidity constraint a particular instrument imposes on consumers. 
Arango and Taylor (2008) consider payment instrument decisions from a merchant's perspective using a 2006 survey of Canadian merchants. They find that merchants' preferences are shaped by both costs and the relative intensity of payment instrument use by their customers. However, they use an analysis of payment instrument market shares relative to merchant perceptions of cost, reliability and risk of crime to show that merchants have little control over their customers' payment instrument decisions beyond their decision to accept an instrument. They also discuss merchants' concerns about reliability of an instrument and the risk of loss from crime.

\section{Consumer costs of adoption, habit and learning}

Schreft (2006) warns of an additional concern for payment instrument choice, consumer decisions are complex. Consistent with this, literature points to the barrier posed by significant irreversible costs to the adoption of new payment instruments by consumers. Yang and Ching (2009) use a structured consumer lifecycle model to estimate the cost of Italian consumers adopting ATM cards. They show the cost of adoption is nontrivial and arises because of factors such as non-pecuniary learning costs incurred at the time of adoption and uncertainty about the acceptance of new technology. They also argue the benefits of adoption are variable because younger people can expect to benefit by using a new technology for a longer period, explaining the link between a consumer's age and their adoption decisions. Similarly, Ackerberg and Gowrisankaran (2006) find consumer irreversible costs of adoption are a substantial impediment to the adoption of $\mathrm{ACH}$ direct entry payments by banks and consumers in the US when they analyse data on ACH adoption decisions between 1995 and 1997. In contrast to consumers' costs, they find the costs of adoption for banks are low and do not explain much of why ACH has not been more widely adopted. 
The irreversible costs of adopting new instruments faced by consumers are consistent with one common observation in the literature, the importance of consumer habit. For example, Guariglia and Loke (2004) show the importance of consumer habit (which they measure by the lagged use of instruments) to the adoption of non-cash payment instruments when they study instrument use, by volume and value, in 15 developed, EU and G10 countries between 1990 and 1998. (I discuss the results of this paper further in subsection 2.4.4 when I investigate literature on whether to measure payment instrument adoption by the value or volume of transactions made using an instrument.)

Consumer irreversible costs of adoption are likely to influence the way dispersion of new payment instruments occurs. For example, Ching (2010) investigates the diffusion of generic drugs that copy a name brand drug after the expiry of its patent, noting that customers are heterogeneous and some are more price sensitive than others. Rather than fixed costs of adoption, he shows that consumer uncertainty that includes pessimistic priors about the quality of generic drugs creates a process whereby patients learn from others about generic drugs, the more price sensitive a patient the more quickly he or she tries the generic drug. While product uncertainty and price sensitivity are different to the fixed costs of adoption, it seems likely that user heterogeneity contributes to a similar learning process for consumer adoption of payment instruments. The literature does support the existence of such a learning process with payment instruments. Van Hove (2006) highlights the role of public transport in stored-value card applications by showing it can underpin usage of stored-value instruments. He quotes (p. 392) Eric Tai, Chief Executive Officer of the Hong Kong stored-value system, Oyster, who said in 2005: “[w] have a killer application - transportation, which customers have to use on a regular basis." I link this to consumer learning because, if a consumer already holds an instrument for a specific purpose, they are more likely to subsequently try to use it as a general payment instrument, particularly if they see those around them using it. Such a 
learning process will contribute to a gradual dispersion of new payment instruments among consumers, raising the importance of network effects, which I turn to, below.

\section{Network effects}

The importance of network effects to retail payment systems is well established in the literature. In subsection 2.3.1, I discussed the work of Liebowitz and Margolis (1994). Given the potential existence of a dynamic process of learning similar to that described by Ching (2008), Liebowitz and Margolis' definition of network effects that I gave in section 1.4 seems very relevant. A particular network effect relevant to retail payment systems is the chicken and egg problem. This simultaneity problem was described in the context of retail payment systems by Evans and Schmalensee (2005a): who came first, merchants willing to accept an instrument or consumers wishing to use it? There is little doubt that the idea has some importance: although Bolt et al (2008) suggest prices have a limited influence on debit card adoption in Norway and the Netherlands, one factor they show to be more important is terminal availability. They find that a $10 \%$ rise in the availability of terminals in Norway relative to the Netherlands increases the relative usage by $5.3 \%$ while a $10 \%$ rise in the relative price of debit card transactions decreases relative usage by just $2.2 \%$.

Guibourg (2001) considers network effects from a different perspective, that of interconnectivity of networks. She argues that network effects increase the benefit of interconnecting payment networks. Guiborg's approach to networks is different to the one I use, which I discuss in subsection 2.4.2: she defines (p. 13) a network in terms of interconnection. Her analysis of data from 1988-1999 for the G-10 countries as well as Australia, Denmark, Finland and Norway show that countries with a lower number of separate networks (i.e. greater inter-connectivity) experience greater transaction 
growth. ${ }^{14}$ Guibourg's conclusion that governments should encourage network interconnection seems superficial, however, as her paper does not explain why networks would not choose themselves to interconnect. For example, do regulatory impediments explain the lack of interconnection? In addition to this question, I find Guibourg's paper is not altogether helpful because of problems defining what interconnection is when networks do not require merchants to have a terminal in order to use its instruments. For these reasons, I consider the role of interconnection, but only in my historical analyses of countries, rather than in my earlier tabular summaries of the systems in my sample countries.

Finally, while network effects might be important, I believe care should be taken to proper analyse factors contributing to their importance. For example, Kemppainen (2003, p. 36) attributes the lack of success of stored-value payment instruments in many countries to the importance of network effects without providing any further analysis of factors. In contrast, Chakravorti (2000) uses analysis of US trials of stored-value instruments to support the statement that the failure of such trials resulted from a failure to convince consumers and merchants that they should use and accept such instruments. While Chakravorti's statement could be interpreted in terms of network effects, I find the greater depth of his analysis more helpful and adopt his approach to network effects in my thesis. For example, I observe payment networks structure themselves in order to increase demand for their instruments by overcoming network effects.

\section{Culture and adoption}

In his analysis of medieval trade, Greif (2006) pays close attention to the role of people's culture (including their religion) in the institutions that get used for medieval

\footnotetext{
14 Data problems, including multicollinearity, prevent Guibourg from distinguishing between the effects of the number of inter-connected networks and the number of proprietary networks in each country.
} 
trade. This raises the question, to what extent is culture a motivation in adoption of payment instruments. Two papers refute it playing any significant role. Deungoue (2008) assesses changes in banks' offerings of five payment instruments, cash, card, ${ }^{15}$ cheque, credit transfer and direct debit in the context of legislative attempts to create a Single Payment Area in the European Monetary Union between 1990 and 2001. She argues that consumer behaviour in countries is converging because of more consistent regulation of payment instruments and of retail banking (which, she argues, influences payment instruments by causing a greater standardisation of retail banks' products). This, she believes, indicates that institutions associated with regulation are important to instrument choices in the EMU. Similarly, Mann (2002) analyses the use of credit and debit cards in the US and Japan. He argues that the difference in the use of credit cards in the two countries is driven by regulations that, until recently, prevented banks from lending revolving credit, an important basis for the issuance of credit cards. He argues that bank-issued credit cards not being able to offer revolving credit meant they were used more like a debit card, which, in turn, meant debit cards were not developed in Japan as they were in the US. Mann supports his arguments with initial evidence showing the removal of these regulations has resulted in early signs of convergence in card usage in the two countries. I note both of these papers, Deungoue (2008) and Mann (2002), draw a distinction between a country's culture and its government's restrictions of freedom, outlining that the second plays a greater role in retail payment system development. I return to this point in subsection 2.4.3 when I analyse literature on the role of government in retail payment systems. 


\subsubsection{Institutions and Payment Networks}

In this subsection, I describe literature relating to the structure of the institutions of payment networks. I start by analysing literature supporting my approach to defining payment networks before investigating literature that shows how those networks interact as they compete with each other. I follow this by discussing literature on each of network structuring, pricing and network rules with a focus on how networks overcome network effects of the sort described above.

\section{Definitions}

As I discussed in section 1.3, I define payment instruments as being provided by payment networks, with one or more networks that offer similar instruments making up a retail payment system. Bakos and Nault (1997) employ an analysis of ownership of, and investment in, electronic networks (such as the Internet and information systems) in a world of incomplete contracts. They show that networks are best defined economically with reference to their ownership and participation. This approach stands in contrast to the definition of network provided by Katz and Shapiro (1985), who, in their analysis of network effects, competition and compatibility, define a network in terms of interconnection. Guibourg (2001) used this approach in her analysis of the important of inter-connectivity for retail payment systems, which I described in subsection 2.4.1. I find this latter definition unhelpful for assessing retail payment systems because, according to it, if payment instruments are interconnected, they are part of the same network. Although I chose not to use their approach in my work, I highlight the subjectivity involved with defining a payment network by mentioning Anderson and Rivard (1999). They assess the definition of ATM/POS debit card payment networks when they consider the approach of Canadian authorities to the Interac debit card payment network. They argue that such networks can be described 
with reference to "(a) the network switch; (b) network ownership and governance; (c) network participants; (d) network fees and (e) operating rules and regulations", an approach they use to assess the authorities' regulation of Interac. Their paper gives readers an idea of the variety of factors relevant to network definition. While defining a network in this way may be the most defendable way to assess government and judicial legal actions, I stick with Bakos and Nault's approach because it is based on a framework of incomplete contracts, which will be a key issue during the development of new retail payment systems that my thesis studies. In summary, my approach holds that a retail payment system may be made up of one or more different networks, defined with reference to their participation or ownership of assets, but which provide a similar type of payment instrument. ${ }^{16}$

Separately from a payment network, I define a payment scheme as being an organisation that provides payment networks with a common structure, including rules and wholesale pricing, which networks can use as they provide instruments to users. The two most common payment schemes are Visa and MasterCard. Differences in the operations of payment networks in different jurisdictions, however, mean payment schemes are distinct from payment networks. The literature indicates a strong reason for differences in the operations of particular networks, the amount of competition they face.

\section{Role of competition}

Several important papers have described the role of competition in the development of retail payment systems. It can occur on a number of different levels: between retail

\footnotetext{
16 I note that my approach when defining a payment network is roughly equivalent to that employed by Board of Governors of the Federal Reserve System (2010, p. 53) when defining a "payment card network" in a recently released notice of proposed rulemaking in relation to debit card interchange fees and routing.
} 
payment systems, between payment networks and within a payment network. While some authors question that competition provided by newly-developed systems raises welfare ${ }^{17}$ Garcia-Swartz, Hahn and Layne-Farrar (2006) support the role of competition between retail payment systems when they empirically estimate costs and benefits of electronic payment systems. ${ }^{18}$ They show that society has benefited, overall, from competition between payment systems and the shift towards electronic payment instruments. Garcia-Swartz et al criticise many studies that preceded theirs as analysing only the costs of using different retail payment instruments (such as the fees paid by merchants) and disregarding the wider transaction cost benefits (such as the convenience). They attempt to remedy this deficit by using their own social and private cost-benefit analysis for all parties for the same transactions made using different instruments. While such valuations are difficult to make, they argue that, when all key parties are considered and all benefits are added, the shift toward a cashless society appears to have improved economic welfare. This highlights the role of payment system competition and the importance of considering payment system choices made by consumers and merchants.

Chakravorti and Roson (2004) go beyond competition between retail payment systems to consider competition between payment networks. ${ }^{19}$ They use a mathematical model to show that inter-network competition within a payment system unambiguously increases transaction volume and therefore consumer and merchant welfare. I consider the extent of inter-network competition in my research and subsequent analysis.

17 For example, Frankel and Shampine (2006) believe that it increases costs and distorts market outcomes by encouraging the use of less efficient payment systems.

18 Garcia-Swartz et al's calculations are not without controversy. In particularly, the paper's results are further discussed in Shampine (2007) with a reply in Garcia-Swartz, Hahn and Layne-Farrar (2007).

19 Chakravorti and Roson do not clarify how they define a payment network and a payment system, instead appearing to assume that Visa and MasterCard are payment networks. I argue this approach is consistent with the one I have taken. 
Chakravorti and Roson focus their analysis on consumers and merchants and do not consider the choices of banks between networks. Evans and Schmalensee (2005a, pp. 275-284) consider these choices when they discuss the interest of anti-trust authorities in the rules of credit card networks around what is known as "duality" or banks issuing the cards of more than one network. The nature of competition for participants in payment networks does seem relevant to this thesis and I return to it in my analysis.

It is also possible to look beyond inter-network competition to investigate that occurring at the intra-network level. I find, however, the concept difficult to consider, conceptually, and several papers warn about the risk of ignoring one side of two-sided platforms: for example, Wright (2004) and Evans (2008) warn that doing this means applying ill-suited economic logic to two-sided platforms. Wright examines eight qualitative ideas he labels as fallacies involving the misapplication of conventional economic theory when considering the structure of prices observed in two-sided markets. These include considering the nature of prices relative to costs and only those prices faced by one side of the market. Evans (2008) investigates the concept of market definition used during anti-trust analysis and agrees with the approach of Wright when he argues that a two-sided platform requires a market definition that includes both sides. $^{20}$ Given its focus on the institutional structure of different systems, I adopt an approach consistent with Wright and Evans and consider conduct from the perspective of both sides of the market.

This is not to say that competition occurring on one side of a two sided platform is not important for payment instruments; the literature strongly suggests that it is. For example, Evans and Schmalensee (2005a, p. 156) say that, while it is difficult to

20 This pragmatic approach is not without a number of theoretical complications. Evans and Schmalensee (2005b), Emch and Thompson (2006) and White (2006) provide some discussion of the pros and cons of the doing this. 
document, intense competition between issuers for customers will cause a greater proportion of the revenue received by issuers from interchange fees to be passed on to customers. However, my approach is to consider both sides of two-sided platforms, thereby considering inter-network competition rather than solely intra-network competition. In the case of Evans and Schmalensee's observation, my approach leads me to ask, does more competition for consumers lead to more use of an instrument rather than other instruments - what happens to the merchant side of the two-sided platform?

\section{Network structuring}

The literature I discussed above suggests that networks structure themselves in order to compete for the issuers and acquirers of a payment instrument, as well as for the users of a payment instrument. Much of the recent literature on retail payment systems deals with the economic rationale for the structuring of payment networks, particularly a network's choices in the setting of a particular wholesale fee internal to a network, the interchange fee. This fee is paid between acquirers and issuers, redistributing revenues payment networks receive from merchants and consumers. I adopt the approach of the Reserve Bank of Australia (2004, October 14, notes to Graph 2) and define positive interchange fees as being paid by acquirers to issuers with negative fees paid in the opposite direction. Positive fees effectively raise the cost of accepting payment instruments for merchants and, for this reason, have generated much scholarly interest. ${ }^{21}$ I also analyse the nature of a fee paid to a payment network operator by one or both of the acquirer and issuer, which is known as a switch fee. While this fee is less important

21 For example, Frankel and Shampine (2006) argue that positive interchange fees distort market outcomes by encouraging the use of more costly payment instruments. As discussed earlier in this subsection, however, Garcia-Swartz et al (2006) disagree with this point. They argue that, while difficult to determine social costs of different payment instruments conclusively, a shift from paperbased to electronic payment systems does appear to be efficient, implying the market remains competitive. 
to the funding of a two-sided platform within a payment system, Katz (2005, p. 123) argues that it may attenuate or strengthen the flows associated with the system's interchange fees and therefore cannot be ignored.

Evans and Schmalensee (2005b) consider the historical context of, as well as alternatives to, interchange fees used by credit card payment systems. When Diner's Club introduced its payment card in 1949, it collected the majority of its revenue from the merchant side of the business. Early four-party credit card networks followed this approach by setting a multilaterally-determined interchange fee paid by acquirers to issuers. A multilateral fee reduced the transactions costs internal to payment networks by removing the need for bilateral negotiations between pairs of network participants. The networks agreed a common interchange fee that left banks with an incentive to compete for merchants' business. Small and Wright (2002) focus further on the feasibility of decentralised negotiations of interchange fees. In a decentralised network, interchange fees are negotiated bilaterally. Small and Wright show this would expose acquiring firms to hold-up by small issuers and lead to an increase in such fees, decreasing the use of credit card payment systems. Accordingly, they indicate that multilaterally set interchange fees are preferable for the smooth operation of payment networks. I consider the prevalence of multilateral interchange fees by specifying in my tables in Chapter 3 whether or not I judge the operations of payment networks to be centralised. I argue that evidence such as Small and Wright (2002) suggests operations will commonly be centralised and I judge this operations to be centralised if evidence indicates that an organisation needs agreements with the majority of issuers and acquirers within a network before it can participate.

Decisions on how to structure networks obviously pertain to institutional design and, in subsection 2.3.1, I discussed literature showing that transaction costs are important to 
this. I described four factors important to the structuring of retail payment systems: asset specificity, irregular transactional activity, ${ }^{22}$ uncertainty and innovation. Economising associated transaction costs will have a fundamental importance to the supply of instruments. For this reason, I will describe how payment networks economise transaction costs as they provide payment instruments to merchants and consumers.

The relevance of transaction costs mean I turn to the possibility of differences between the levels of transaction costs that exist in my sample countries. As shown in my summary of key statistics for my sample country in Table 1.1, a major difference between my countries is their population size, which may have an important influence on transaction costs if having a lower population reduces the number of organisations needed by a payment network. However, when she investigates the structure of the banking markets, Dick (2007) investigates the role of market size in banking market concentration. She finds that banking industries are similarly concentrated, regardless of size, indicating that I should not expect major differences in the transaction costs associated with payment network structuring because of the different populations of my sample's countries. Claessens and Laeven (2004) do, however, identify one important reason for differences between my countries when they estimate the degree of competition in 5 countries' bank industries using bank panel data from 1994 to 2001. They find no negative relationship between competitiveness and bank concentration, but do find greater foreign bank entry to an industry with fewer entry and activity restrictions to be more competitive.

\section{Pricing}

22 While transactions made using a payment network's instrument will occur very regularly, the transactions that create that network occur much less regularly. 
Having surveyed the literature on the role of competition in retail payment systems, I turn to its effects, firstly by investigating literature on the decisions of networks. As discussed in subsection 2.4.2, Rochet and Tirole (2003) show that a platform will compete with other platforms by choosing a pricing structure that ensures the participation of both sides in a two-sided platform. They describe three important factors for pricing decisions:

- The presence of marquee buyers (consumers generating a high surplus for merchants) makes it more beneficial for merchants to offer payment systems preferred by them, raising the price merchants will be willing to pay

- Installed bases or captive buyers on one side of the two-sided platform tilt the price structure in favour of the other side

- If one side multi-homes, or can access a platform in a number of different ways, the price structure will be (counter-intuitively) tilted in favour of the other side (because the other side can steer the first side to use its preferred platform).

These three observations highlight important aspects to the price structures chosen by payment networks to get both sides onboard. An idea central to these aspects is that, if one side of the two-sided platform is more likely to participate, the price structure will favour the other side. Rochet and Tirole (2006b) support applying this idea to payment cards when they say that merchants will often internalise a card's benefit to cardholders, making them willing to pay significant per-transaction fees known as merchant service fees ("MSFs"). I now discuss literature that confirms the role of each of these three factors.

As he investigates pricing structures used by platforms with two or more sides in industries such as payment cards, software and real estate, Evans (2003) observes 
pricing consistent with Rochet and Tirole's predictions. In relation to marquee buyers, Evans provides the example of American Express, a three-party credit/charge card network. It can charge a relatively high MSF compared to other card brands because merchants view the American Express business clientele as particularly attractive. This means merchants will still want to participate in the network despite higher costs. In relation to captive buyers/installed bases of users, Evans (2003) discusses how ATM networks had an installed base of consumers who used their cards to access cash using ATMs. When debit card services were added to ATM cards, networks needed to encourage merchants to install terminals that could process transactions using ATM cards. Accordingly, networks' pricing structure favoured merchants relative to other payment cards. While Evans shows multihoming is common to many two-sided platforms, he does not present clear evidence from the payment card industry regarding its effect on pricing. Rysman (2006), however, provides more insight when he shows the subtleness of the multihoming effect as he investigates credit and debit card usage in the US between 1998 and 2001. He finds that consumers concentrate their spending on a single payment network (single-home), although many hold unused cards that allow the ability to use multiple networks (multi-home). Although he does not offer a conclusive answer as to why this happens, Rysman does investigate factors behind consumers' choices of favoured network. He finds that customers' favoured network is likely to be the network most widely accepted. My framework provides analysis of why this might happen, which I describe in subsection 5.2.2.

The discussion above shows that pricing decisions are not self-evident; rather they are context-specific influenced by behaviour on both sides of the market. Nevertheless, there is little doubt that pricing does play some role in system development. I investigate the nature of per-transaction, retail prices faced by both consumers and merchants when accessing different payment systems. Shy and Wang (2008) observe 
that many networks making up the American credit card payment system charge fees that are proportional to transaction value. For fees with this nature, I use the label, "proportional fees" (although these are also known as ad valorem fees). I define pertransaction fees that do not change with transaction value as "flat fees". As well as marginal fees, I acknowledge the role of fixed fees as being important to instrument adoption decisions. In their analysis of payment instrument pricing in the Netherlands and Norway, which I described above, Bolt et al (2008) focused on marginal, pertransaction fees, which they said would play a "key" role in adoption of instruments by consumers, although they did acknowledge (p. 91) that fixed fees may also play a small role in adoption. I take a similar approach to them as I focus on consumers' and merchants' decisions to use a payment system. Although I focus on marginal, pertransaction fees in my Chapter 3 tables that show features of the card-based, merchantbased instruments of major payment networks within retail payment systems, fixed fees will remain important to my subsequent analysis.

\section{Network rules}

At the end of my analysis on the literature on network structuring, I mentioned there were two important choices available to networks. Here, I turn to the second of them, investigating what the literature indicates regarding payment network rules. Weiner and Wright (2005) discusses the use, internationally, of a variety network rules that often form part of four-party credit and debit card networks. I focus on two rules that have attracted particular regulatory and judicial attention: ${ }^{23}$

23 Among commentators noting the interest in these rules are Heikkinen (2007), Wright (2003) and Negrin (2005). 
- the No-Surcharge Rule, which prevent merchants from charging customers for the use of a particular payment mechanism, in this case, a credit card (also known as the no-discrimination rule)

- the Honour-All-Cards Rule, which, in the US or Australia, require merchants that accept a network's credit card to also accept that network's signature-based debit card, if the latter exists in that country (also known as the handle-all-cards rule). ${ }^{24}$

Wright (2003) argues that removal of the No-Surcharge Rule allows monopolistic merchants to charge differential prices for credit card users. This reduces the benefits the cardholder obtains from surcharged transactions resulting in the "undersubscription" of the card network, especially when cardholders face a fixed cost when joining a network. Monnet and Roberds (2007) consider a mathematical model of a payment network and highlight the importance of a No-Surcharge Rule to participation in the network and therefore to entry of new retail payment systems.. By reducing agents' incentive to deal in cash, the rule increases participation and the viability of a payment network. Bolt, Jonker and van Renselaar (2009) take a different approach and empirically analyse the number of Danish merchants who react to acquirers charging them flat fees for processing debit card transactions by surcharging. They find that $22 \%$ of Dutch merchants surcharge and those who do surcharge do not do so for transactions greater than, on average, 10 EUR. Furthermore, Bolt et al calculate that merchants who surcharged debit card transactions charged 23 euro cents on average, compared with an average MSF of 4-5 euro cents. This suggests that some merchants respond to elasticities of demand for their customers that are different for small purchases. Evans and Schmalensee (2005b, p. 93) propose two reasons why, when able to do so, more

24 An alternative definition, which I do not use, but which is more common for credit cards in Europe, is that the Honour-All-Cards Rule requires merchants who accept a scheme's card to always accept that card no matter who the issuer. 
merchants choose not to surcharge: there are transaction costs of imposing different prices based on payment methods; and that consumers may patronize other stores that do not surcharge.

Rochet and Tirole (2008) turn to the Honour-All-Cards Rule and show how the rule performs a socially beneficial rebalancing effect between the interchange fees charged by two platforms (such as debit and credit cards) facing different levels of competition. They point to support for their model coming from the observation that Visa and MasterCard reduced their debit interchange fees and increased their credit interchange fees following the removal of the Honour-All-Cards Rule in the US in 2003.

In order to understand the effect on payment system development of network rules, I investigate whether these two network rules, the No-Surcharge Rule and the HonourAll-Cards Rule, are explicitly part of the payment systems surveyed. I focus on the explicit use of such rules because some researchers, such as Epstein (2005, p. 582), argues that such rules will not be enforced, absolutely, but will be "porous" in nature. At the beginning of my discussion of network rules, I mentioned regulator and government interest in these particular rules. I further analyse literature on the role of government in the next subsection.

\subsubsection{Government Involvement in Retail Payment Systems}

I begin this subsection by admitting the existence of a substantial and important opportunity for analysis: understanding the institutions of government. My focus on the institutions of retail payment system development means I define these government institutions as exogenous: while I analyse their role in system development, I do not attempt to understand the reasons for their existence. I do not, however, mean my approach to diminish the importance of these institutions, instead arguing that the literature indicates they can in fact play an important role. In relation to the adoption of 
payment instruments by users in subsection 2.4.1, I described two papers that indicated governments play a key role in the adoption of payment instruments. Firstly, Deungoue (2008) finds convergence in instrument adoption in EMU countries following the standardisation of regulations of payment instruments and retail banking. Similarly, Mann (2002) finds convergence in instrument adoption between the US and Japan following the latter's removal of rules that prevented banks from lending revolving credit.

A variety of motivations have been advanced for government involvement in retail payment systems and in economic activity, more generally. Viscusi, Vernon and Harrington (1995) consider a general framework for why governments regulate markets - they consider (in Chapter 10) the application of what they call, normative analysis as a positive theory, which holds that regulation is supplied in response to the public's demand for a correction of a market failure or for the correction of highly inequitable practices. However, they report (p. 326) that a key reason why this theory has lacked supporters in recent times is the large amount of evidence that refutes it. They critically examine the economic theory of regulation, which is advanced in place of normative analysis as a positive theory. This newer theory holds that regulation is supplied in response to demands of interest groups acting to maximise their income. Accepting that intervention might not always be in the interest of the general public, I summarise the literature on two major objectives for government intervention that appear to at least start with a public interest motivation.

The first public interest objective I consider is a desire for governments to ensure the stability of their country's financial system. Because retail payment systems are often provided by members of a country's financial system, financial regulation is likely to affect retail payment system development. In two papers forming part of a compendium 
of work analysing financial regulation, Goodhart (2007) and Capie (2007) analyse the history of the creation and maintenance of financial regulation in different countries for approximately the previous 150 years. They both show an historical process exists that started with comparatively little financial regulation, but with such regulation increasing in extent in response to crises, as part of reactive efforts to ensure the stability of financial systems. As I explained at the beginning of this subsection, I treat the institutions of government (including of financial regulation) as beyond the scope of this thesis. However, I find it useful in my analysis to observe that governments introduce an amount of financial regulation to attain a level of stability in financial systems. I make no further assumptions around the extent of this regulation - indeed, both Goodhart and Capie report a range of approaches to such regulation exist in different countries. Instead, I observe the effects of financial regulation in my sample countries on retail payment system development.

A second public interest objective is a government's desire to prevent restrictions on competition that are detrimental to society and it has led to the development in many countries of what is termed, competition policy. ${ }^{25}$ While the relevance of competition policy to retail payment system development may not be immediately obvious, Kemppainen (2003) points to the operation of retail payment systems, which often requires cooperation amongst firms that are otherwise competitors, as bringing "competition policy considerations into the picture". Motta (2004) defines competition policy (also known as, anti-trust policy) as the set of policies and laws made which ensure competition in a marketplace is not restricted in a way that is detrimental to society. He uses the well-known Sherman Act, which was created as US federal law in

25 Carletti and Hartmann (2002) use a survey of theoretical and empirical evidence to analyse the relationship between competition policies and policies to preserve stability in the banking sector. They find little relationship between the two and, given my treatment of these policies as exogenous, I provide no further analysis of that relationship here. 
1890, as an early example. Motta argues that the over-riding objective of competition policy should be to maximise total welfare and, although he does not go as far to recommend it as an objective, he acknowledges the role of dynamic efficiency in this standard. However, he makes it plain in his discussion that it is not the only public interest objective of what gets labelled, competition policy. As with financial regulation, I limit my analysis of competition authorities to analysis their effects of financial regulation on retail payment system development.

These two public interest objectives are not the only reasons advanced for government intervention in retail payment systems. Other reasons appear more consistent with the economic theory of regulation proposed by Verscusi et al (1995). Heikkinen (2007) discusses the "substantial" regulatory pressure on card-based payment systems. She argues that complaints from merchants, which especially focus on MSFs, explain why most past and current propositions for regulation have focused on the relationship between the payment card industry and participating merchants. In relation to MSFs and merchants' pricing, Guerin-Calvert and Ordover (2005) analyse merchant complaints in the context of remedies available to merchants and government regulators in regard to an obvious payment system price for credit card networks, the interchange fee. They argue that merchant complaints have, in large part, precipitated regulator concerns that interchange fees are "too high". They discuss the complex problem of analysing merchant benefits from processing transactions using payment cards and, thus, the complexities involved with defining an interchange fee that is "too high". Nevertheless, it appears that merchant pressure leads governments to attempt to regulate prices of payment cards. ${ }^{26}$ However, I also believe care needs to be taken not to 
exaggerate the importance of merchants to the regulation of retail payment systems. In Australia, merchant complaints about positive interchange fees charged in credit card networks arguably led to the eventual regulation of negative interchange fees for EFTPOS transactions. In spite of merchants taking several unsuccessful court cases attempting to stop it, the regulation of EFTPOS interchange fees resulted in transactions made using this instrument becoming more costly for merchants.

In regard to governments' influence on network rules, I described my focus on two in the preceding subsection, the No-Surcharge Rule and the Honour-All-Cards Rule, which governments and authorities have often intervened to remove. I suggest that analysis of payment networks' adoption of these two Rules will to an extent measure government involvement with their operations.

\subsubsection{Measuring Adoption: Volume vs. Value and Other Data Issues}

There are two key ways of measuring adoption of recently developed payment instruments: the volume of transactions completed using instruments or their total value. For several reasons, I focus solely on the volume of transactions. Guariglia and Loke (2004) provide evidence showing the relative merits of each measure using data from 14 developed, EU and G10 countries between 1990 and 1998. They find both transaction volume and value are affected by past payment habits and the extent of payment instrument infrastructure (measured by the number of EFTPOS terminals), but that they find subtle distinctions in the influences on the two variables. One subtlety is that Guariglia and Loke find a negative relationship between cash holdings and the volume of card transactions, but a positive relationship between cash holdings and their value. They argue this is consistent with a common feature of debit card systems, minimum 
transaction values, which reduce the volume of debit card transactions, but have less effect on their value. Secondly, they find that the interest rate is positively related to the value, but not the volume, of non-cash transactions, which they suggest happens because an increase in the interest rate raises the opportunity cost of holding a larger amount of cash. This is a further reason for focusing on volume. Although Guaiglia and Loke (2004) are silent on the effect of income on the two variables, there are reasons for thinking that income will have a greater effect on value of a country's noncash transactions, rather than their volume. Kravis and Lipsey (1982) are among researchers observing a link between price levels and a country's wealth. More costly goods will mean greater exchanges of value in each transaction. Consistent with this idea, Snellman, Vesala and Humphrey (2001) analyse substitution of non-cash payment instruments for cash in 10 European countries and estimate that income (GDP per capita) has a positive effect on the value of cash holdings. This makes it likely that the value of transactions completed by non-cash payment instruments is also positively correlated with income. Turning to the volume of transactions, Humphrey et al (1996, p. 931) use data for 1987-1993 in 14 developed countries and show no clear relationship between income and the volume of transactions made using non-cash payment instruments (they do not analyse the value of transactions). I also note that the two countries with the largest amount of retail payment system use measured by volume shown in Figure 1.1, Norway and New Zealand, are also my sample's richest and poorest, respectively, as measured by the GDP Per Capita figures shown in Table 1.1.

\section{Other Data Issues}

In my introduction to this thesis, I showed the usage of debit and credit cards in each of my sample countries in Figure 1.1. As clarified on the Figure, it is based on transactional data from official sources for each country, being the Committee on 
Payment and Settlement Systems (the "CPSS"), which regularly updates statistical information for a document known as the Redbook, the Reserve Bank of Australia, Norges Bank and Statistics New Zealand. ${ }^{27}$ The lack of data on cash-only transactions from some official sources (in particular, Statistics New Zealand) means I focus only on transactions for the purchase of goods and services (that is, I exclude data for transactions that only have a cash-out component). For data from the CPSS Redbooks, I use the report for the years 2004 to 2008. To get the volume of transactions per capita, I use population data also available from the sources above with the exception of Australia for which I use data from the Australian Bureau of Statistics. When I find a discrepancy between figures for the same year provided in separate documents, I use those provided in the most recent publication. I further clarify my data sources in my analysis of country-by-country retail payment system development in Chapter 4.

Another data issue for payment instruments is that there are two ways of measuring transaction volume in a country: the volume of issued transactions, being the number of transactions on cards issued in a country, and the volume of acquired transactions, being the number of transactions on merchant terminals in a country. The two will be separated by the card use of that country's residents as they travel in other countries compared to the card use of international tourists as they travel within that country. In my country-by-country summaries in Chapter 4 , I state whether the transaction volume data I use is for issued transactions or acquired transactions. Given my preference for using consistent data from official sources, I am almost always constrained by the nature of the data available, which, with the exception of acquired transactions for New Zealand and the US, is for the volume of issued transactions.

\footnotetext{
27 Official sources commonly do not separate credit card transactions into those made using three-party card instruments from those made using four-party card instruments. For this reason, my tables in Chapter 3 showing the attributes of payment networks show only aggregated transaction data.
} 
I investigate the appropriateness of comparing data for issued transaction volumes with data for acquired transaction volumes, which my reliance on official sources forces me to adopt, by analysing differences between acquired transactions and issued transactions for the two countries for which both are available; these are Norway and the UK. Figures from Norway's central bank, Norges Bank, allow a comparison of issued transactions to acquired transactions for the combined amounts of debit and credit card transaction volumes. ${ }^{28}$ Between 2000 and 2009, issued transactions are at most 5.1\% greater than acquired transactions, averaging 3.6\%. Data from the UK Cards Association show acquired transactions, in contrast to CPSS Redbook data for the UK, which show issued transactions. The issued transaction data from the CPSS for credit and debit cards are at most 5.6\% more than the acquired transaction data from the UK Cards Association and average $2.5 \%$ more.

\subsection{Focus of my Research}

The discussion above shows the complexity involved with retail payment systems. I will attempt to add to the literature on retail payment systems by adopting a historybased institutional analysis. Such an approach will provide an alternative analytical method to mathematical equilibrium analysis; one that I feel may be better suited to understanding retail payment systems' complexities.

28 That is, the figures do not allow issued and acquired transactions on debit cards to be separated from those on credit cards. 


\section{Chapter 3}

\section{Important Features of Payment Instruments}

In this Chapter, I provide tables showing the important features, particularly the pricing and usage, of instruments provided by major payment networks in retail payment systems in each of my sample countries. My tables focus on the features of networks offering card-based, merchant-based instruments that I define as being major because I have readily found evidence allowing me to summarise their features. There will of course be networks that I have not summarised because I have not found sufficient information showing their features. I describe what the columns in each of my tables refer to:

- The row headers in the first column of my tables show which the retail payment system of that row or collection of rows. When I have found distinct payment networks are in the same retail payment system (by virtue of providing the same type of payment instrument), I place each network in a separate row, but wth the same row header (first column)

- The second and third columns list major network names and whether or not I judge their operations to be centralised, according to the definitions of networks and centralised operations that I discussed in subsection 2.4.2

- The fourth column shows the usage of the retail payment system, as measured by the average number of transactions per capita in 2008. As I discussed in subsection 2.4.4, my official data sources generally provide data aggregated for debit and credit cards, preventing me from showing data separated for different payment networks

- The fifth and sixth columns show current per-transaction retail fees for POS transactions charged to merchants and consumers. None means no per-transaction 
fees are charged. Fixed refers to per-transaction fees that do not change in size with the size of the transaction. Some fixed refers to fees that, depending on a consumer's account, are generally either zero or fixed. Proportional refers to fees that are proportional to the transaction's value

- The seventh and eight columns show the two wholesale per-transaction fees, the interchange fee and the switch fee. I clarify the nature of interchange fees (whether they are flat or proportional) and if the paid from acquirer to issuer (positive fees) or in the other direction (negative fees). I also clarify the nature of switch fees, which are paid to the payment network operator, and whether they are paid by the acquirer or issuer

- Finally, the ninth and tenth columns show whether or not I have found information showing whether or not payment networks explicitly make use of the Honour-All-Cards and No-Surcharge Rules, which I described in subsection 2.4.2.

I follow each of my tables with tables showing my sources for each cell. I have left cells blank when I have not found convincing evidence for me to summarise the particular feature of that network. For some blank cells, I include a reference for readers to follow, should they be interested. 


\subsection{Australia}

\begin{tabular}{|c|c|c|c|c|c|c|c|c|c|}
\hline \multirow{2}{*}{$\begin{array}{l}\text { Retail Payment } \\
\text { System }\end{array}$} & \multirow{2}{*}{$\begin{array}{l}\text { Network } \\
\text { Names }\end{array}$} & \multirow{2}{*}{$\begin{array}{cc}\text { Central } \\
\text { Ops. }\end{array}$} & \multirow{2}{*}{$\begin{array}{c}\text { Transactions } \\
\text { per Capita, } \\
2008\end{array}$} & \multicolumn{2}{|c|}{$\begin{array}{l}\text { Per-Transaction } \\
\text { Retail Fees }\end{array}$} & \multicolumn{2}{|c|}{$\begin{array}{c}\text { Per-Transaction } \\
\text { Wholesale Fees }\end{array}$} & \multicolumn{2}{|c|}{ Network Rules } \\
\hline & & & & To Merchant & To Consumer & $\begin{array}{c}\text { Interchange } \\
\text { Fee }\end{array}$ & Switch Fee & $\begin{array}{c}\text { Honour-All- } \\
\text { Cards }\end{array}$ & $\begin{array}{c}\text { No- } \\
\text { Surcharge }\end{array}$ \\
\hline $\begin{array}{l}\text { Three-Party } \\
\text { Credit/Charge } \\
\text { Card }\end{array}$ & $\begin{array}{l}\text { AMEX, } \\
\text { Diners Club, } \\
\text { JCB }\end{array}$ & $\begin{array}{c}-7-7 \\
1 \\
1 \\
1 \\
-7\end{array}$ & 68 & $\begin{array}{l}\text { Proportional } \\
\text { fee }\end{array}$ & None & na & & na & $\mathrm{N}$ \\
\hline $\begin{array}{l}\text { Four-Party } \\
\text { Credit Card }\end{array}$ & $\begin{array}{l}\text { Visa, } \\
\text { Mastercard }\end{array}$ & $\begin{array}{c}1 \\
1 \\
1 \\
1\end{array}$ & & $\begin{array}{l}\text { Proportional } \\
\text { fee }\end{array}$ & None & $\begin{array}{l}\text { Positive } \\
\text { proportional } \\
\text { fee }\end{array}$ & & $\mathrm{N}$ & $\mathrm{N}$ \\
\hline Debit Card & $\begin{array}{l}\text { EFTPOS } \\
\text { Visa Debit, } \\
\text { Debit } \\
\text { Mastercard }\end{array}$ & $\begin{array}{c}1 \\
1 \\
1 \\
1 \\
1 \\
1 \\
1\end{array}$ & 81 & $\begin{array}{l}\text { Some flat fees } \\
\text { Flat fee }\end{array}$ & Some flat fees & $\begin{array}{l}\text { Negative flat } \\
\text { fee } \\
\text { Positive flat } \\
\text { fee }\end{array}$ & None & $-\bar{N}$ & $\overline{\mathrm{N}}$ \\
\hline
\end{tabular}

NB: For a description of this table, please see the text at the beginning of this Chapter. 
References for Australia

\begin{tabular}{|c|c|c|c|c|c|c|c|c|c|}
\hline \multirow{2}{*}{$\begin{array}{l}\text { Retail Payment } \\
\text { System }\end{array}$} & \multirow{2}{*}{$\begin{array}{l}\text { Network } \\
\text { Names }\end{array}$} & \multirow{2}{*}{$\begin{array}{l}\text { Central } \\
\text { Ops. }\end{array}$} & \multirow{2}{*}{$\begin{array}{c}\text { Transactions } \\
\text { per Capita, } \\
2008\end{array}$} & \multicolumn{2}{|c|}{$\begin{array}{c}\text { Per-Transaction } \\
\text { Retail Fees }\end{array}$} & \multicolumn{2}{|c|}{$\begin{array}{c}\text { Per-Transaction Wholesale } \\
\text { Fees }\end{array}$} & \multicolumn{2}{|c|}{ Network Rules } \\
\hline & & & & To Merchant & To Consumer & $\begin{array}{l}\text { Interchange } \\
\text { Fee }\end{array}$ & Switch Fee & $\begin{array}{l}\text { Honour-All- } \\
\text { Cards }\end{array}$ & $\begin{array}{l}\text { No- } \\
\text { Surcharge }\end{array}$ \\
\hline $\begin{array}{l}\text { Three-Party } \\
\text { Credit/Charge } \\
\text { Card }\end{array}$ & $\begin{array}{l}\text { Weiner \& } \\
\text { Wright (2005, p. } \\
297)\end{array}$ & & $\begin{array}{c}\text { See subsection } \\
4.1 .5 \text { of this } \\
\text { thesis }\end{array}$ & $\begin{array}{l}\text { Reserve Bank } \\
\text { of Australia } \\
(2007, \text { p. } 22)\end{array}$ & & & & $\begin{array}{r}\text { Reserve Bank } \\
(2007\end{array}$ & $\begin{array}{l}\text {, of Australia } \\
\text { p. } 6)\end{array}$ \\
\hline $\begin{array}{l}\text { Four-Party } \\
\text { Credit Card }\end{array}$ & $\begin{array}{l}\text { Weiner \& } \\
\text { Wright }(2005, \text { p. } \\
\text { 297); Author }\end{array}$ & & & $\begin{array}{l}\text { Reserve Bank } \\
\text { of Australia } \\
(2007, \text { p. } 22)\end{array}$ & & $\begin{array}{l}\text { Reserve Bank } \\
\text { of Australia } \\
(2007, \text { p. 6) }\end{array}$ & & $\begin{array}{r}\text { Reserve Bank } \\
(2007\end{array}$ & $\begin{array}{l}\text { of Australia } \\
\text { p. } 6)\end{array}$ \\
\hline Debit Card & $\begin{array}{l}\text { Weiner \& } \\
\text { Wright (2005, p. } \\
304) \\
\\
\text { Weiner \& } \\
\text { Wright }(2005, \mathrm{p} . \\
304) \\
\ldots\end{array}$ & 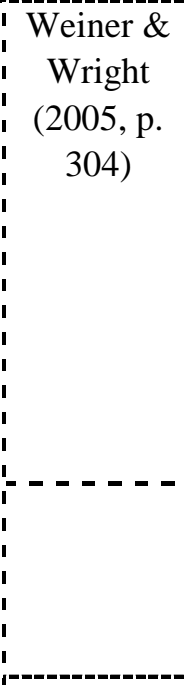 & $\begin{array}{l}\text { See subsection } \\
4.1 .5 \text { of this } \\
\text { thesis }\end{array}$ & $\begin{array}{l}\text { Reserve Bank } \\
\text { of Australia } \\
\text { (2007, p. 22) }\end{array}$ & $\begin{array}{l}\text { Reserve Bank } \\
\text { of Australia } \\
(2007, \text { p. 23) } \\
\\
\text { td (2010, April } \\
010, \text { April 17) }\end{array}$ & $\begin{array}{l}\text { Reserve Bank } \\
\text { of Australia } \\
\text { (2007, p. 6) } \\
\\
\text { Reserve Bank } \\
\text { of Australia } \\
\text { (2007, p. 6) }\end{array}$ & $\begin{array}{c}\text { Arun } \\
\text { Campbell, } \\
\text { Australian } \\
\text { Payments } \\
\text { Clearing } \\
\text { Association, } \\
\text { personal } \\
\text { communicatio } \\
\text { n, June 17, } \\
2010\end{array}$ & $\begin{array}{r}\text { Reserve Bank } \\
(2007\end{array}$ & of Australia \\
\hline
\end{tabular}




\subsection{Canada}

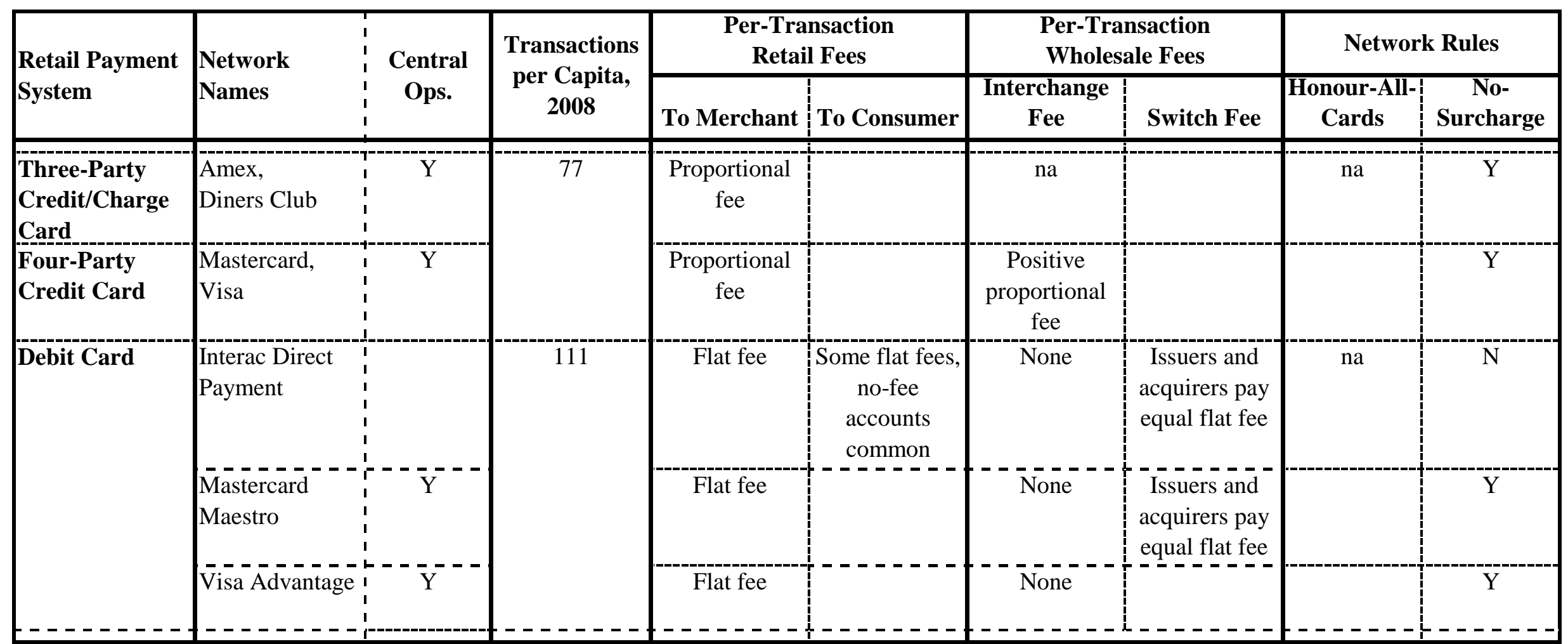

NB: For a description of this table, please see the text at the beginning of this Chapter. 
References for Canada

\begin{tabular}{|c|c|c|c|c|c|c|c|c|c|}
\hline \multirow{2}{*}{$\begin{array}{l}\text { Retail Payment } \\
\text { System }\end{array}$} & \multirow{2}{*}{$\begin{array}{l}\text { Network } \\
\text { Names }\end{array}$} & \multirow{2}{*}{$\begin{array}{c}\text { Central } \\
\text { Ops. }\end{array}$} & \multirow{2}{*}{$\begin{array}{c}\text { Transactions } \\
\text { per Capita, } \\
2008\end{array}$} & \multicolumn{2}{|c|}{$\begin{array}{c}\text { Per-Transaction } \\
\text { Retail Fees }\end{array}$} & \multicolumn{2}{|c|}{$\begin{array}{c}\text { Per-Transaction Wholesale } \\
\text { Fees }\end{array}$} & \multicolumn{2}{|c|}{ Network Rules } \\
\hline & & & & To Merchant & To Consumer & $\begin{array}{l}\text { Interchange } \\
\text { Fee }\end{array}$ & Switch Fee & $\begin{array}{l}\text { Honour-All- } \\
\text { Cards }\end{array}$ & $\begin{array}{c}\text { No- } \\
\text { Surcharge }\end{array}$ \\
\hline $\begin{array}{l}\text { Three-Party } \\
\text { Credit/Charge } \\
\text { Card }\end{array}$ & $\begin{array}{l}\text { Weiner and \& } \\
\text { Wright (2005, p. } \\
\text { 297) }\end{array}$ & & $\begin{array}{c}\text { See subsection } \\
4.2 .5 \text { of this } \\
\text { thesis }\end{array}$ & $\begin{array}{l}\text { Arango \& } \\
\text { Taylor }(2008, \\
\text { p. } 10)\end{array}$ & & & & & $\begin{array}{l}\text { Standing } \\
\text { Senate } \\
\text { Committee } \\
(2009, \text { p. 21) }\end{array}$ \\
\hline $\begin{array}{l}\text { Four-Party } \\
\text { Credit Card }\end{array}$ & $\begin{array}{l}\text { Weiner and \& } \\
\text { Wright (2005, p.: } \\
\text { 297) }\end{array}$ & & & $\begin{array}{l}\text { Arango \& } \\
\text { Taylor }(2008, \\
\text { p. } 10)\end{array}$ & & $\begin{array}{l}\text { Standing } \\
\text { Senate } \\
\text { Committee } \\
(2009, \text { p. } 2)\end{array}$ & & $\begin{array}{c}\text { Standing } \\
\text { Senate } \\
\text { Committee } \\
(2009, \text { p. 22) }\end{array}$ & $\begin{array}{l}\text { Arnfield } \\
(2009 \text {, } \\
\text { Septermber } \\
\text { 23) }\end{array}$ \\
\hline \multirow[t]{3}{*}{ Debit Card } & \multirow{3}{*}{\begin{tabular}{|l} 
\\
\hdashline
\end{tabular}} & & \multirow[t]{3}{*}{$\begin{array}{l}\text { See subsection } \\
4.2 .5 \text { of this } \\
\text { thesis }\end{array}$} & $\begin{array}{l}\text { Arango \& } \\
\text { Taylor }(2008, \\
\text { p. } 10)\end{array}$ & \multirow[t]{3}{*}{$\begin{array}{l}\text { Canadians } \\
\text { love... (1997, } \\
\text { November 3) }\end{array}$} & $\begin{array}{c}\text { Arnfield } \\
(2009, \\
\text { September 23) }\end{array}$ & $\begin{array}{c}\text { Arnfield } \\
(2009, \\
\text { September 23) }\end{array}$ & & $\begin{array}{l}\text { Arnfield } \\
\text { (2009, } \\
\text { September } \\
\text { 23) }\end{array}$ \\
\hline & & & & $\begin{array}{l}\text { Arnfield } \\
(2009, \\
\text { Septermber } \\
23)\end{array}$ & & $\begin{array}{l}\text { Arnfield } \\
(2009, \\
\text { September 23) }\end{array}$ & $\begin{array}{l}\text { Arnfield } \\
(2009, \\
\text { September 23) }\end{array}$ & $\begin{array}{l}\text { Standing } \\
\text { Senate } \\
\text { Committee } \\
(2009, \text { p. 22) }\end{array}$ & $\begin{array}{l}\text { Arnfield } \\
(2009, \\
\text { September } \\
23)\end{array}$ \\
\hline & & & & $\begin{array}{l}\text { Visa-branded } \\
\text { debit cards... } \\
\text { (2010, October } \\
19)\end{array}$ & & \multicolumn{2}{|c|}{$\begin{array}{c}\text { Visa-branded debit cards } \\
\text { swiping into Canada (2010, } \\
\text { October 19) }\end{array}$} & $\begin{array}{c}\text { Standing } \\
\text { Senate } \\
\text { Committee } \\
(2009, \text { p. } 22)\end{array}$ & $\begin{array}{c}\text { Arnfield } \\
(2009, \\
\text { Septermber } \\
23)\end{array}$ \\
\hline
\end{tabular}




\subsection{Germany}

\begin{tabular}{|c|c|c|c|c|c|c|c|c|c|}
\hline \multirow{2}{*}{$\begin{array}{l}\text { Retail Payment } \\
\text { System }\end{array}$} & \multirow{2}{*}{$\begin{array}{l}\text { Network } \\
\text { Names }\end{array}$} & \multirow{2}{*}{$\begin{array}{l}\text { Central } \\
\text { Ops. }\end{array}$} & \multirow{2}{*}{$\begin{array}{c}\text { Transactions } \\
\text { per Capita, } \\
2008\end{array}$} & \multicolumn{2}{|c|}{$\begin{array}{c}\text { Per-Transaction } \\
\text { Retail Fees }\end{array}$} & \multicolumn{2}{|c|}{$\begin{array}{c}\text { Per-Transaction } \\
\text { Wholesale Fees }\end{array}$} & \multicolumn{2}{|c|}{ Network Rules } \\
\hline & & & & To Merchant & To Consumer & $\begin{array}{c}\text { Interchange } \\
\text { Fee }\end{array}$ & Switch Fee & $\begin{array}{l}\text { Honour-All-1 } \\
\text { Cards }\end{array}$ & $\begin{array}{c}\text { No- } \\
\text { Surcharge }\end{array}$ \\
\hline $\begin{array}{l}\text { Three-Party } \\
\text { Credit/Charge } \\
\text { Card }\end{array}$ & $\begin{array}{l}\text { American } \\
\text { Express, Diners } \\
\text { Club }\end{array}$ & $\begin{array}{c}7 \\
\vdots \\
\vdots \\
1\end{array}$ & 5 & $\begin{array}{l}\text { Proportional } \\
\text { fee }\end{array}$ & None & na & & na & \\
\hline $\begin{array}{l}\text { Four-Party } \\
\text { Credit Card }\end{array}$ & $\begin{array}{l}\text { MasterCard, } \\
\text { Visa }\end{array}$ & ' & & $\begin{array}{c}\text { Proportional } \\
\text { fee }\end{array}$ & None & $\begin{array}{l}\text { Positive } \\
\text { proportional } \\
\text { fee }\end{array}$ & & $\mathrm{Y}$ & \\
\hline Debit Card & $\begin{array}{l}\text { Electronic } \\
\text { Cash/Girocash } \\
\text { ELV/ec direct } \\
\text { debit } \\
\text { MasterCard } \\
\text { Maestro/ } \\
\text { Visa V PAY }\end{array}$ & 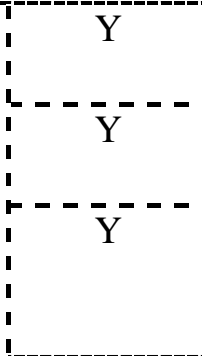 & $23^{(1)}$ & $\begin{array}{l}\text { Proportional } \\
\text { fee } \\
\text { None } \\
\begin{array}{c}\text { Proportional } \\
\text { fee }\end{array}\end{array}$ & $\begin{array}{l}\text { None } \\
\text { None } \\
\text { None }\end{array}$ & $\begin{array}{c}\text { na }^{(2)} \\
\text { None } \\
\begin{array}{c}\text { Positive } \\
\text { proportional } \\
\text { fee }\end{array}\end{array}$ & & na & \\
\hline $\begin{array}{l}\text { Stored-Value } \\
\text { Card }\end{array}$ & Geldkarte & $\mathrm{Y}$ & 1 & $\begin{array}{l}\text { Proportional } \\
\text { fee }\end{array}$ & None & & & na & \\
\hline
\end{tabular}

NB: For a description of this table, please see the text at the beginning of this Chapter.

(1) EHI Retail Institute (2009, p. 16) provides data to obtain a breakdown of debit card transactions in Germany measured by sales value in $2008: 59 \%$ are completed by Girocash, $40 \%$ by ELV/ec direct debit and $1 \%$ by Maestro/V Pay.

(2) In a structure unique to Germany (European Commission, 2006, p. 19), network operators (Netzbetreiber) collect fees from merchants and pass them to the appropriate issuing bank. The fee does not pass through an acquiring bank and therefore isn't an interchange fee. 


\begin{tabular}{|c|c|c|c|c|c|c|c|c|c|}
\hline \multirow{2}{*}{$\begin{array}{l}\text { Retail Payment } \\
\text { System }\end{array}$} & \multirow{2}{*}{$\begin{array}{l}\text { Network } \\
\text { Names }\end{array}$} & \multirow{2}{*}{$\begin{array}{cc}\text { Central } \\
: \text { Ops. } \\
\end{array}$} & \multirow{2}{*}{$\begin{array}{c}\text { Transactions } \\
\text { per Capita, } \\
2008\end{array}$} & \multicolumn{2}{|c|}{$\begin{array}{c}\text { Per-Transaction } \\
\text { Retail Fees }\end{array}$} & \multicolumn{2}{|c|}{$\begin{array}{c}\text { Per-Transaction Wholesale } \\
\text { Fees }\end{array}$} & \multicolumn{2}{|c|}{ Network Rules } \\
\hline & & & & To Merchant & To Consumer & $\begin{array}{c}\text { Interchange } \\
\text { Fee }\end{array}$ & Switch Fee & $\begin{array}{l}\text { Honour-AII- } \\
\text { Cards }\end{array}$ & $\begin{array}{c}\text { No- } \\
\text { Surcharge }\end{array}$ \\
\hline $\begin{array}{l}\text { Three-Party } \\
\text { Credit/Charge } \\
\text { Card }\end{array}$ & & & $\begin{array}{c}\text { See subsection } \\
4.4 .5 \text { of this } \\
\text { thesis }\end{array}$ & \multirow{3}{*}{\multicolumn{2}{|c|}{$\begin{array}{l}\text { Retail Banking Research Ltd } \\
\qquad(2005 a, \text { p. 27-28) }\end{array}$}} & & & & \\
\hline $\begin{array}{l}\text { Four-Party } \\
\text { Credit Card }\end{array}$ & & & & & & $\begin{array}{l}\text { UPDATE 1- } \\
\text { German retail } \\
\text { group files } \\
\text { credit card fees } \\
\text { complaint } \\
\text { (2006, Jan 19) }\end{array}$ & & $\begin{array}{c}\text { Retail } \\
\text { Banking } \\
\text { Research Ltd } \\
(2005 \mathrm{~b}, \mathrm{p} . \\
17)\end{array}$ & $\begin{array}{l}\text { Retail } \\
\text { Banking } \\
\text { Research Ltd } \\
(2005 \mathrm{~b}, \mathrm{p} . \\
46)\end{array}$ \\
\hline Debit Card & $\begin{array}{l}\text { EHI Retail } \\
\text { Institute (2009, } \\
\text { pp. 11, 27) }\end{array}$ & : & $\begin{array}{c}\text { See subsection } \\
4.4 .5 \text { of this } \\
\text { thesis }\end{array}$ & & & $\begin{array}{c}\text { European } \\
\text { Commission } \\
(2006, \text { p. 19) } \\
\text { Germany } \\
\text { passes } \\
\text { important } \\
\text { milestone } \\
(2000, \text { March } \\
17) \\
\text { Visa }(201 \overline{1}, \\
\text { February); } \\
\text { MasterCard } \\
\text { (2011, } \\
\text { February) }\end{array}$ & -- & $\begin{array}{c} \\
\text { Retail } \\
\text { Banking } \\
\text { Rearch Ltd } \\
\text { (2005b, p. } \\
17)\end{array}$ & -- \\
\hline $\begin{array}{l}\text { Stored-Value } \\
\text { Card }\end{array}$ & $\begin{array}{l}\overline{\mathrm{CPSS}}(2000, \overline{\mathrm{pp}} \\
33-34)\end{array}$ & & & $\begin{array}{l}\text { CPSS (2000, } \\
\text { pp. 33-34) }\end{array}$ & $\begin{array}{l}\text { CPSS (2000, } \\
\text { pp. 33-34) }\end{array}$ & & & & \\
\hline
\end{tabular}




\subsection{New Zealand}

\begin{tabular}{|c|c|c|c|c|c|c|c|c|c|}
\hline \multirow{2}{*}{$\begin{array}{l}\text { Retail Payment } \\
\text { System }\end{array}$} & \multirow{2}{*}{$\begin{array}{l}\text { Network } \\
\text { Names }\end{array}$} & \multirow{2}{*}{$\begin{array}{cc}\text { Central } \\
\text { Ops. }\end{array}$} & \multirow{2}{*}{$\begin{array}{c}\text { Transactions } \\
\text { per Capita, } \\
2008\end{array}$} & \multicolumn{2}{|c|}{$\begin{array}{c}\text { Per-Transaction } \\
\text { Retail Fees }\end{array}$} & \multicolumn{2}{|c|}{$\begin{array}{c}\text { Per-Transaction } \\
\text { Wholesale Fees }\end{array}$} & \multicolumn{2}{|c|}{ Network Rules } \\
\hline & & & & To Merchant & To Consumer & $\begin{array}{c}\text { Interchange } \\
\text { Fee }\end{array}$ & Switch Fee & $\begin{array}{l}\text { Honour-All- } \\
\text { Cards }\end{array}$ & $\begin{array}{c}\text { No- } \\
\text { Surcharge }\end{array}$ \\
\hline $\begin{array}{l}\text { Three-Party } \\
\text { Credit/Charge } \\
\text { Card }\end{array}$ & $\begin{array}{l}\text { Amex, } \\
\text { Diners Club }\end{array}$ & $\begin{array}{c}7 \\
1 \\
1 \\
1 \\
1 \\
7\end{array}$ & 60 & $\begin{array}{l}\text { Proportional } \\
\text { fee }\end{array}$ & None & na & & na & $\mathrm{Y}$ \\
\hline $\begin{array}{l}\text { Four-Party } \\
\text { Credit Card }\end{array}$ & $\begin{array}{l}\text { Visa, } \\
\text { Mastercard }\end{array}$ & $\begin{array}{c}-1 \\
1 \\
1\end{array}$ & & $\begin{array}{l}\text { Proportional } \\
\text { fee }\end{array}$ & None & $\begin{array}{l}\text { Proportional } \\
\text { fee }\end{array}$ & & $\mathrm{Y}$ & $\mathrm{N}$ \\
\hline Debit Card & $\begin{array}{l}\text { EFTPOS NZ, } \\
\text { Paymark } \\
\text { EFTPOS } \\
\text { Visa Debit }\end{array}$ & $\begin{array}{l}Y_{1} Y \\
1 \\
1 \\
1\end{array}$ & 181 & None & None & None & $\begin{array}{l}\text { Flat fee paid } \\
\text { by issuer } \\
\text { Flat fee paid } \\
\text { by issuer }\end{array}$ & na & \\
\hline $\begin{array}{l}\text { Stored-Value } \\
\text { Card }\end{array}$ & Snapper & $\begin{array}{l}7 \\
1 \\
1 \\
1\end{array}$ & & $\begin{array}{c}\text { Proportional } \\
\text { fee }\end{array}$ & None & & & na & $\mathrm{Y}$ \\
\hline
\end{tabular}

NB: For a description of this table, please see the text at the beginning of this Chapter. 


\begin{tabular}{|c|c|c|c|c|c|c|c|c|c|}
\hline \multirow{2}{*}{$\begin{array}{l}\text { Retail Payment } \\
\text { System }\end{array}$} & \multirow{2}{*}{$\begin{array}{l}\text { Network } \\
\text { Names }\end{array}$} & \multirow{2}{*}{$\begin{array}{cc}\text { Central } \\
\text { Ops. }\end{array}$} & \multirow{2}{*}{$\begin{array}{c}\text { Transactions } \\
\text { per Capita, } \\
2008\end{array}$} & \multicolumn{2}{|c|}{$\begin{array}{l}\text { Per-Transaction } \\
\text { Retail Fees }\end{array}$} & \multicolumn{2}{|c|}{$\begin{array}{c}\text { Per-Transaction Wholesale } \\
\text { Fees }\end{array}$} & \multicolumn{2}{|c|}{ Network Rules } \\
\hline & & & & To Merchant & To Consumer & $\begin{array}{c}\text { Interchange } \\
\text { Fee }\end{array}$ & Switch Fee & $\begin{array}{l}\text { Honour-All-| } \\
\text { Cards }\end{array}$ & $\begin{array}{c}\text { No- } \\
\text { Surcharge }\end{array}$ \\
\hline $\begin{array}{l}\text { Three-Party } \\
\text { Credit/Charge } \\
\text { Card }\end{array}$ & $\begin{array}{l}\text { Reserve Bank o } \\
\text { New Zealand } \\
(2003, \text { p. } 8)\end{array}$ & $\begin{array}{c}7-1 \\
1 \\
1 \\
1 \\
1 \\
1 \\
1\end{array}$ & $\begin{array}{l}\text { See subsection } \\
4.5 .5 \text { of this } \\
\text { thesis }\end{array}$ & & $\begin{array}{c}\text { Liu et al } \\
(2004, \text { p. } 3)\end{array}$ & & & & \\
\hline $\begin{array}{l}\text { Four-Party } \\
\text { Credit Card }\end{array}$ & $\begin{array}{l}\text { Reserve Bank o } \\
\text { New Zealand } \\
(2003, \text { p. } 8)\end{array}$ & $\begin{array}{c}7 \\
1 \\
1 \\
1 \\
1 \\
1 \\
1\end{array}$ & & & $\begin{array}{c}\text { Liu et al } \\
(2004, \text { p. } 3)\end{array}$ & & & Taylor $(20$ & 10, p. 14) \\
\hline Debit Card & & $\begin{array}{c}1 \\
1 \\
1 \\
1 \\
1\end{array}$ & $\begin{array}{l}\text { See subsection } \\
4.5 .5 \text { of this } \\
\text { thesis }\end{array}$ & $\begin{array}{l}\text { Liu et al } \\
(2004, \text { p. } 5)\end{array}$ & $\begin{array}{l}\text { Matthews \& } \\
\text { Hu }(2006, \mathrm{p} . \\
\text { 11) }\end{array}$ & \multicolumn{2}{|c|}{$\begin{array}{l}\text { Peter McLeod (EFTPOS New } \\
\text { Zealand, 2009, October 22, } \\
\text { personal communication) }\end{array}$} & & \\
\hline $\begin{array}{l}\text { Stored-Value } \\
\text { Card }\end{array}$ & & $\begin{array}{c}1 \\
1 \\
1 \\
1 \\
1 \\
1\end{array}$ & & \multicolumn{2}{|c|}{$\begin{array}{l}\text { Gabor Szikszai (Snapper, } \\
\text { 2010, February } 15, \text { personal } \\
\text { communication) }\end{array}$} & & & \multicolumn{2}{|c|}{$\begin{array}{l}\text { Gabor Szikszai (Snapper, } \\
2010 \text {, February } 15, \\
\text { personal communication) }\end{array}$} \\
\hline
\end{tabular}


3.5 Norway

\begin{tabular}{|c|c|c|c|c|c|c|c|c|c|}
\hline \multirow{2}{*}{$\begin{array}{l}\text { Retail Payment } \\
\text { System }\end{array}$} & \multirow{2}{*}{$\begin{array}{l}\text { Network } \\
\text { Names }\end{array}$} & \multirow{2}{*}{$\begin{array}{c}\text { Central } \\
\text { Ops. }\end{array}$} & \multirow{2}{*}{$\begin{array}{c}\text { Transactions } \\
\text { per Capita, } \\
2008\end{array}$} & \multicolumn{2}{|c|}{$\begin{array}{c}\text { Per-Transaction } \\
\text { Retail Fees }\end{array}$} & \multicolumn{2}{|c|}{$\begin{array}{c}\text { Per-Transaction } \\
\text { Wholesale Fees }\end{array}$} & \multicolumn{2}{|c|}{ Network Rules } \\
\hline & & & & To Merchant & To Consumer & $\begin{array}{c}\text { Interchange } \\
\text { Fee }\end{array}$ & Switch Fee & $\begin{array}{l}\text { Honour-AII- } \\
\text { Cards }\end{array}$ & $\begin{array}{c}\text { No- } \\
\text { Surcharge }\end{array}$ \\
\hline $\begin{array}{l}\text { Three-Party } \\
\text { Credit/Charge } \\
\text { Card }\end{array}$ & $\begin{array}{l}\text { Diners Club, } \\
\text { American } \\
\text { Express, } \\
\text { Domestic credit } \\
\text { cards }\end{array}$ & $\mathrm{Y}$ & $24^{(1)}$ & $\begin{array}{l}\text { Proportional } \\
\text { fee }\end{array}$ & & na & & na & \\
\hline $\begin{array}{l}\text { Four-Party } \\
\text { Credit Card }\end{array}$ & $\begin{array}{l}\text { Visa, } \\
\text { Mastercard }\end{array}$ & Y & & $\begin{array}{l}\text { Proportional } \\
\text { fee }\end{array}$ & & $\begin{array}{l}\text { Positive } \\
\text { proportional } \\
\text { fee }\end{array}$ & & $\mathrm{Y}$ & $Y$ \\
\hline Debit Card & $\begin{array}{l}\text { BankAxept } \\
\text { Visa, } \\
\text { Mastercard }\end{array}$ & $\begin{array}{c}Y \\
Y \\
Y\end{array}$ & $191^{(1)}$ & $\begin{array}{l}\text { None, or very } \\
\text { low, flat fee } \\
\text { None, or very } \\
\text { low, flat fee }\end{array}$ & $\begin{array}{c}\text { Flat fee } \\
\text { Flat fee }\end{array}$ & $\begin{array}{l}\text { None } \\
\text { None }\end{array}$ & & na & 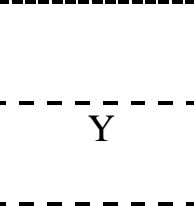 \\
\hline
\end{tabular}

NB: For a description of this table, please see the text at the beginning of this Chapter.

(1) Figures do not include use of Norwegian cards abroad and assume that category of "Cards issued by international card companies" are all credit/charges cards rather than debit cards 


\subsubsection{Norwegian References}

\begin{tabular}{|c|c|c|c|c|c|c|c|c|c|}
\hline \multirow{2}{*}{$\begin{array}{l}\text { Retail Payment } \\
\text { System }\end{array}$} & \multirow{2}{*}{$\begin{array}{l}\text { Network } \\
\text { Names }\end{array}$} & \multirow{2}{*}{$\begin{array}{c}\text { Central } \\
\text { Ops. }\end{array}$} & \multirow{2}{*}{$\begin{array}{c}\text { Transactions } \\
\text { per Capita, } \\
2008\end{array}$} & \multicolumn{2}{|c|}{$\begin{array}{l}\text { Per-Transaction } \\
\text { Retail Fees }\end{array}$} & \multicolumn{2}{|c|}{$\begin{array}{c}\text { Per-Transaction Wholesale } \\
\text { Fees }\end{array}$} & \multicolumn{2}{|c|}{ Network Rules } \\
\hline & & & & To Merchant & To Consumer & $\begin{array}{c}\text { Interchange } \\
\text { Fee }\end{array}$ & Switch Fee & $\begin{array}{c}\text { Honour-All-1 } \\
\text { Cards }\end{array}$ & $\begin{array}{c}\text { No- } \\
\text { Surcharge }\end{array}$ \\
\hline $\begin{array}{l}\text { Three-Party } \\
\text { Credit/Charge } \\
\text { Card }\end{array}$ & $\begin{array}{l}\text { Norges Bank } \\
(2007, \text { pp. } 58 \text {, } \\
60)\end{array}$ & & $\begin{array}{c}\text { See subsection } \\
4.6 .5 \text { of this } \\
\text { thesis }\end{array}$ & $\begin{array}{l}\text { Norges Bank } \\
(2007, \text { p. 14) }\end{array}$ & & & & & \\
\hline $\begin{array}{l}\text { Four-Party } \\
\text { Credit Card }\end{array}$ & $\begin{array}{l}\text { Norges Bank } \\
(2007, \text { p. 60) }\end{array}$ & & & $\begin{array}{l}\text { Norges Bank } \\
(2007, \text { p. 14) }\end{array}$ & & $\begin{array}{l}\text { Norges Bank } \\
\text { (2007, p. 14) }\end{array}$ & & $\begin{array}{c}\text { Kredittilsyne } \\
\mathrm{t}(2004 \mathrm{p} . \\
41)\end{array}$ & $\begin{array}{l}\text { Kredittilsyne } \\
\mathrm{t}(2004 \mathrm{p} . \\
43)\end{array}$ \\
\hline Debit Card & $\begin{array}{l}\text { Norges Bank } \\
(2007, \text { p. } 7)\end{array}$ & & $\begin{array}{c}\text { See subsection } \\
4.6 .5 \text { of this } \\
\text { thesis }\end{array}$ & $\begin{array}{c}\text { Gresvik \& } \\
\text { Haare }(2009 b, \\
\text { p. } 24)\end{array}$ & $\begin{array}{c}\text { Norges Bank } \\
\text { (2006b, p. 24) }\end{array}$ & $\begin{array}{l}\text { Norges Bank } \\
(2007, \text { p. 14) }\end{array}$ & & & \\
\hline & $\begin{array}{l}\text { Norges Bank } \\
(2007, \text { p. } 7)\end{array}$ & & & $\begin{array}{l}\text { Kredittilsynet } \\
(2004, \text { p. } 17) \\
\text { Gresvik \& } \\
\text { Haare }(2009 b, \\
\text { p. } 24)\end{array}$ & $\begin{array}{l}\text { Norges Bank } \\
\text { (2006b, p. 24) }\end{array}$ & $\begin{array}{l}\text { Kredittilsynet } \\
\text { (2004, p. 17); } \\
\text { Norges Bank } \\
(2007, \text { p. 14) }\end{array}$ & & $\begin{array}{c}\text { Kredittilsyne } \\
\mathrm{t}(2004 \mathrm{p} \\
41)\end{array}$ & $\begin{array}{l}\text { Kredittilsyne } \\
\mathrm{t}(2004 \mathrm{p} . \\
43)\end{array}$ \\
\hline
\end{tabular}




\subsection{United Kingdom}

\begin{tabular}{|c|c|c|c|c|c|c|c|c|c|}
\hline \multirow{2}{*}{$\begin{array}{l}\text { Retail Payment } \\
\text { System }\end{array}$} & \multirow{2}{*}{$\begin{array}{l}\text { Network } \\
\text { Names }\end{array}$} & \multirow{2}{*}{$\begin{array}{c}\text { Central } \\
\text { Ops. }\end{array}$} & \multirow{2}{*}{$\begin{array}{c}\text { Transactions } \\
\text { per Capita, } \\
2008\end{array}$} & \multicolumn{2}{|c|}{$\begin{array}{c}\text { Per-Transaction } \\
\text { Retail Fees }\end{array}$} & \multicolumn{2}{|c|}{$\begin{array}{c}\text { Per-Transaction } \\
\text { Wholesale Fees }\end{array}$} & \multicolumn{2}{|c|}{ Network Rules } \\
\hline & & & & To Merchant & To Consumer & $\begin{array}{c}\text { Interchange } \\
\text { Fee }\end{array}$ & Switch Fee & $\begin{array}{c}\text { Honour-All- } \\
\text { Cards }\end{array}$ & $\begin{array}{c}\text { No- } \\
\text { Surcharge }\end{array}$ \\
\hline $\begin{array}{l}\text { Three-Party } \\
\text { Credit/Charge } \\
\text { Card }\end{array}$ & $\begin{array}{l}\text { Amex, } \\
\text { Diners Club }\end{array}$ & $\mathrm{Y}$ & 32 & $\begin{array}{l}\text { Proportional } \\
\text { fee }\end{array}$ & None & na & & na & \\
\hline $\begin{array}{l}\text { Four-Party } \\
\text { Credit Card }\end{array}$ & $\begin{array}{l}\text { Visa, } \\
\text { MasterCard }\end{array}$ & $\mathrm{Y}$ & & $\begin{array}{l}\text { Proportional } \\
\text { fee }\end{array}$ & None & $\begin{array}{c}\text { Positive } \\
\text { proportional } \\
\text { fee }\end{array}$ & & $\mathrm{Y}$ & $\mathrm{N}$ \\
\hline Debit Card & $\begin{array}{l}\text { Solo, Maestro, } \\
\text { Visa Debit, Visa } \\
\text { Electron }\end{array}$ & $\mathrm{Y}$ & 89 & Flat fee & None & $\begin{array}{c}\text { Positive flat } \\
\text { fee }\end{array}$ & & $\mathrm{Y}$ & $\mathrm{N}$ \\
\hline
\end{tabular}

NB: For a description of this table, please see the text at the beginning of this Chapter. 


\begin{tabular}{|c|c|c|c|c|c|c|c|c|c|}
\hline \multirow{2}{*}{$\begin{array}{l}\text { Retail Payment } \\
\text { System }\end{array}$} & \multirow{2}{*}{$\begin{array}{l}\text { Network } \\
\text { Names }\end{array}$} & \multirow{2}{*}{$\begin{array}{l}\text { Central } \\
\text { Ops. }\end{array}$} & \multirow{2}{*}{$\begin{array}{c}\text { Transactions } \\
\text { per Capita, } \\
2008\end{array}$} & \multicolumn{2}{|c|}{$\begin{array}{l}\text { Per-Transaction } \\
\text { Retail Fees }\end{array}$} & \multicolumn{2}{|c|}{$\begin{array}{c}\text { Per-Transaction Wholesale } \\
\text { Fees }\end{array}$} & \multicolumn{2}{|c|}{ Network Rules } \\
\hline & & & & To Merchant & To Consumer & $\begin{array}{c}\text { Interchange } \\
\text { Fee }\end{array}$ & Switch Fee & $\begin{array}{l}\text { Honour-All- } \\
\text { Cards }\end{array}$ & $\begin{array}{l}\text { No- } \\
\text { Surcharge }\end{array}$ \\
\hline $\begin{array}{l}\text { Three-Party } \\
\text { Credit/Charge } \\
\text { Card }\end{array}$ & $\begin{array}{l}\mathrm{OECD}(2006, \mathrm{p} \\
243)\end{array}$ & & $\begin{array}{l}\text { See subsection } \\
4.7 .5 \text { of this } \\
\text { thesis }\end{array}$ & $\begin{array}{l}\text { Office of Fair } \\
\text { Trading (2003, } \\
\text { p. 110) }\end{array}$ & $\begin{array}{l}\text { Office of Fair } \\
\text { Trading } \\
(2005 a, p .12)\end{array}$ & & & & \\
\hline $\begin{array}{l}\text { Four-Party } \\
\text { Credit Card }\end{array}$ & $\begin{array}{l}\mathrm{OECD}(2006, \mathrm{p} . \\
243)\end{array}$ & & & $\begin{array}{l}\text { Office of Fair } \\
\text { Trading (2003, } \\
\text { p. } 110)\end{array}$ & $\begin{array}{l}\text { Office of Fair } \\
\text { Trading } \\
(2005 b, \text { p. } 120)\end{array}$ & $\begin{array}{l}\text { Office of Fair } \\
\text { Trading } \\
(2005 \mathrm{a}, \mathrm{p} .12)\end{array}$ & & $\begin{array}{c}\text { Retail } \\
\text { Banking } \\
\text { Research } \\
(2005, \text { p. } 17)\end{array}$ & $\begin{array}{l}\text { Office of } \\
\text { Fair Trading } \\
(2005 \mathrm{a}, \mathrm{p} \text {. } \\
14)\end{array}$ \\
\hline Debit Card & $\begin{array}{l}\text { OECD }(2006, p . \\
243)\end{array}$ & & $\begin{array}{c}\text { See subsection } \\
4.7 .5 \text { of this } \\
\text { thesis }\end{array}$ & $\begin{array}{l}\text { Van Hove } \\
(2007, \text { p. } 8)\end{array}$ & $\begin{array}{l}\text { Office of Fair } \\
\text { Trading } \\
(2005 b, p .121)\end{array}$ & $\begin{array}{l}\text { Office of Fair } \\
\text { Trading } \\
(2005 \mathrm{a}, \mathrm{p.} .12)\end{array}$ & & $\begin{array}{c}\text { Retail } \\
\text { Banking } \\
\text { Research } \\
(2005, \text { p. } 17)\end{array}$ & $\begin{array}{l}\text { Office of } \\
\text { Fair Trading } \\
(2005 b, p . \\
121)\end{array}$ \\
\hline
\end{tabular}




\subsection{United States}

\begin{tabular}{|c|c|c|c|c|c|c|c|c|c|}
\hline \multirow{2}{*}{$\begin{array}{l}\text { Retail Payment } \\
\text { System }\end{array}$} & \multirow{2}{*}{$\begin{array}{l}\text { Network } \\
\text { Names }\end{array}$} & \multirow{2}{*}{$\begin{array}{l}\text { Central } \\
\text { Ops. }\end{array}$} & \multirow{2}{*}{$\begin{array}{c}\text { Transactions } \\
\text { per Capita, } \\
2008\end{array}$} & \multicolumn{2}{|c|}{$\begin{array}{c}\text { Per-Transaction } \\
\text { Retail Fees }\end{array}$} & \multicolumn{2}{|c|}{$\begin{array}{l}\text { Per-Transaction } \\
\text { Wholesale Fees }\end{array}$} & \multicolumn{2}{|c|}{ Network Rules } \\
\hline & & & & To Merchant & To Consumer & $\begin{array}{c}\text { Interchange } \\
\text { Fee }\end{array}$ & Switch Fee & $\begin{array}{c}\text { Honour-All- } \\
\text { Cards }\end{array}$ & $\begin{array}{c}\text { No- } \\
\text { Surcharge }\end{array}$ \\
\hline $\begin{array}{l}\text { Three-Party } \\
\text { Credit/Charge } \\
\text { Card }\end{array}$ & $\begin{array}{l}\text { American } \\
\text { Express, } \\
\text { Discover, } \\
\text { JCB }\end{array}$ & 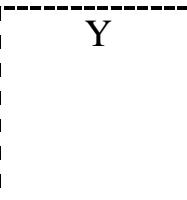 & $79^{(1)}$ & $\begin{array}{l}\text { Proportional } \\
\text { fee }\end{array}$ & None & na & & na & \\
\hline $\begin{array}{l}\text { Four-Party } \\
\text { Credit Card }\end{array}$ & $\begin{array}{l}\text { Mastercard, } \\
\text { Visa }\end{array}$ & 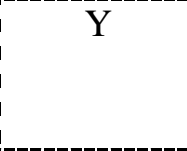 & & $\begin{array}{l}\text { Proportional } \\
\text { fee }\end{array}$ & None & $\begin{array}{c}\text { Positive } \\
\text { proportional } \\
\text { fee }\end{array}$ & & $\mathrm{N}$ & $\mathrm{Y}$ \\
\hline Debit Card & $\begin{array}{l}\text { 14 'PIN' online } \\
\text { networks } \\
\text { Mastercard, } \\
\text { Oisa 'signature' } \\
\text { offline networks }\end{array}$ & 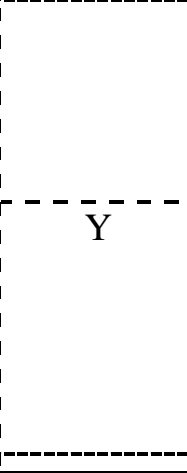 & $113^{(2)}$ & $\begin{array}{l}\text { "Largely" flat } \\
\text { fees } \\
\text { proportional } \\
\text { fees }\end{array}$ & $\begin{array}{l}\text { Some flat fees } \\
\text { None }\end{array}$ & $\begin{array}{c}\text { Positive fixed } \\
\text { fees, } \\
\text { proportional } \\
\text { fees } \\
\text { Positive } \\
\text { proportional } \\
\text { fee }\end{array}$ & $\begin{array}{l}\text { Flat fee paid } \\
\text { by issuer and } \\
\text { acquirer }\end{array}$ & $\bar{N}$ & $\bar{Y}$ \\
\hline
\end{tabular}

NB: For a description of this table, please see the text at the beginning of this Chapter.

(1) Figure includes private label cards, which I have not summarised on this table.

(2) According to the 2007 Federal Reserve Payments Study, PIN debit made up 37\% of these transactions and signature debit, $63 \%$, in 2006. 


\begin{tabular}{|c|c|c|c|c|c|c|c|c|}
\hline \multirow{2}{*}{$\begin{array}{l}\text { Retail Payment } \\
\text { System }\end{array}$} & \multirow{2}{*}{$\begin{array}{l}\text { Network } \\
\text { Names }\end{array}$} & \multirow{2}{*}{$\begin{array}{l}\text { Central } \\
\text { Ops. }\end{array}$} & \multirow{2}{*}{$\begin{array}{c}\text { Transactions } \\
\text { per Capita, } \\
2008\end{array}$} & \multicolumn{2}{|c|}{$\begin{array}{l}\text { Per-Transaction } \\
\text { Retail Fees }\end{array}$} & \multicolumn{2}{|c|}{$\begin{array}{c}\text { Per-Transaction Wholesale } \\
\text { Fees }\end{array}$} & Network Rules \\
\hline & & & & To Merchant & To Consumer & $\begin{array}{l}\text { Interchange } \\
\text { Fee }\end{array}$ & Switch Fee & \begin{tabular}{c|c} 
Honour-All-- & No- \\
Cards & Surcharge
\end{tabular} \\
\hline $\begin{array}{l}\text { Three-Party } \\
\text { Credit/Charge } \\
\text { Card }\end{array}$ & $\begin{array}{l}\text { Weiner \& } \\
\text { Wright }(2005 \text {, p. } \\
\text { 297) }\end{array}$ & & $\begin{array}{c}\text { See subsection } \\
4.8 .5 \text { of this } \\
\text { thesis }\end{array}$ & $\begin{array}{c}\text { Mann }(2002, \mathrm{p} . \\
1094)\end{array}$ & $\begin{array}{l}\text { Zinman }(2009 \\
\text { p. } 360)\end{array}$ & & & \\
\hline $\begin{array}{l}\text { Four-Party } \\
\text { Credit Card }\end{array}$ & $\begin{array}{l}\text { Weiner \& } \\
\text { Wright }(2005 \text {, p. } \\
297)\end{array}$ & & & $\begin{array}{c}\text { Mann }(2002, \mathrm{p} \\
1094)\end{array}$ & $\begin{array}{l}\text { Zinman }(2009 \\
\text { p. } 360)\end{array}$ & $\begin{array}{l}\text { Weiner \& } \\
\text { Wright }(2005 \text {, } \\
\text { p. 293) }\end{array}$ & & $\begin{array}{l}\text { Weiner \& Wright }(2005, \mathrm{p} . \\
\text { 298) }\end{array}$ \\
\hline Debit Card & $\begin{array}{l}\text { Weiner \& } \\
\text { Wright }(2005, \text { p. } \\
304)\end{array}$ & & $\begin{array}{c}\text { See subsection } \\
4.8 .5 \text { of this } \\
\text { thesis }\end{array}$ & $\begin{array}{l}\text { United States } \\
\text { Department of } \\
\text { Justice (2003, } \\
\text { p. } 7 \text { ) }\end{array}$ & $\begin{array}{c}\text { Hayashi, } \\
\text { Sullivan \& } \\
\text { Weiner (2006, } \\
\text { p. 13) }\end{array}$ & $\begin{array}{l}\text { Hayashi, } \\
\text { Sullivan \& } \\
\text { Weiner (2003, } \\
\text { p. 78) }\end{array}$ & $\begin{array}{c}\text { Hayashi, } \\
\text { Sullivan \& } \\
\text { Weiner (2006, } \\
\text { pp. 37-38) }\end{array}$ & \\
\hline & $\begin{array}{l}\text { United States } \\
\text { Department of } \\
\text { Justice }(2003, \text { p. } \\
7 \text { ) }\end{array}$ & & & $\begin{array}{l}\text { United States } \\
\text { Department of } \\
\text { Justice (2003, } \\
\text { p. } 7 \text { ) }\end{array}$ & $\begin{array}{l}\text { Hayashi, } \\
\text { Sullivan \& } \\
\text { Weiner (2003, } \\
\text { p. 52) }\end{array}$ & $\begin{array}{c}\text { Hayashi, } \\
\text { Sullivan \& } \\
\text { Weiner (2003, } \\
\text { p. } 78)\end{array}$ & & $\begin{array}{l}\text { Weiner \& Wright }(2005, \mathrm{p} \text {. } \\
302)\end{array}$ \\
\hline
\end{tabular}




\subsection{Observations from my Tables}

I make a number of observations from analysis of my tables:

- Only Australia and the US have major networks (both offering debit cards) that I do not judge to be centralised. ${ }^{1}$

- I found only New Zealand and Germany to have major networks offering storedvalue instruments.

- $\quad$ As I observed in my discussion of Figure 1.1, Germany has relatively very low usage of debit and credit cards. Its usage of stored-value cards also appears very low, although I have not found other observations to compare this with.

- Merchants face proportional fees for POS transactions made using three-party credit/charge cards and four-party credit cards in all of my sample countries while consumers do not face transaction fees for such instruments, at least in the majority of countries, . For four-party credit cards, this retail pricing was underpinned by positive proportional interchange fees in all of my sample countries.

- In the two countries with the highest usage of debit cards, New Zealand and Norway, merchants are not charged (significant) per-transaction fees for POS transactions. Of the other countries, merchants in Germany and the US are charged proportional fees (in the case of the US, on the majority of transactions) and merchants in Australia, Canada and the UK are (generally) charged flat fees. Such fees are underpinned by positive interchange fees, except in the cases of Australia, New Zealand and Norway. Australia has negative flat fees for its

Although I have not deemed US online debit card networks to be decentralized, evidence indicates that 14 networks exist, far higher than the number of networks in any of the other retail payment systems in my sample countries. 
EFTPOS transactions, but no switch fees. While New Zealand has no interchange fees for debit card transactions, it has flat switch fees paid solely by the issuer. There are no debit card interchange fees in Norway, although I have not found evidence on the nature of Norwegian switch fees.

- $\quad$ Finally, I observe little relationship between the usage of payment cards in my sample countries and the prevalence of two network rules I analyse. Significant numbers of networks operate without using one or both rules, however. When considered alongside the literature I discussed in subsection 2.4.3, this suggests significant government involvement with retail payment systems in all of my sample countries, with the possible exception of Norway.

While these observations go some way to indicating possible reasons for the adoption of card-based, merchant payment instruments, they do not answer the research question that I posed in section 1.7. In particular, the tables provide no indication of why the systems developed in the way that they did. In Chapter 4, I turn to an historical analysis of retail payment system development to investigate how and why such development occurred. 


\section{Chapter 4}

\section{Historical Reviews of Retail Payment System Development}

Consistencies in the political environments between my sample countries mean that I set out my historical summaries by dividing the chronology of each country's retail payment system development into four subsections. Chronological divisions will not be exact and, on several occasions, events I associate with one subsection happen before events in a preceding subsection. My four subsections are:

- development of retail payment systems during a time of significant government intervention in the banking industry

- $\quad$ significant changes to the ways in which the financial system was regulated

- developments following these changes and

- developments during a period of government or government authorities intervening in the operations of payment networks within retail payment systems.

I add two subsections for each country. The first discusses my sources for statistics that show the adoption of credit and debit card, the data that underpins Figure 1.1 and my tables in Chapter 3. The second includes a bibliography for each specific country in my sample with each bibliography including references for information in my tables in Chapter 3.

In addition to sections on each of my sample countries, I include one (section 4.3) that investigates the importance of the European Union to the three European countries in my sample, Germany, Norway and the United Kingdom. I summarise lessons from my summaries in section 4.9. 


\subsection{Australia}

\subsubsection{Retail Payment Systems and Government Controls on Banking}

Grenville (1991) provides a summary of the extent and effects of banking sector regulation in the decades following World War 2. At this time, banks operated with "a complex set of overlapping controls which represented a 'belts and braces' approach to constrain the banks' balance sheets without relying on higher interest rates."2

Furthermore, new entry into banking in Australia was not thought possible until the 1980s (Davis, 2003, p. 12). Harper (1991) argues the controls facilitated a profitable cartel amongst the banks and hampered product innovation.

\section{Bankcard and other Australian joint-ventures}

Besides cash and cheque, innovations involving retail payment systems initially centred on the three party credit card networks, American Express and Diners Club, and a number of store cards, which, according to one media report, were mainly used by wealthy individuals (Weekes, 2006, February 3). Following agreement with the Reserve Bank of Australia ("RBA") and the Australian Federal Government, a group of nine Australian banks launched Bankcard, a four party credit card network, in October 1974 by mailing cards to bank customers (Innis, 2006, February 15). A desire to share electronic data processing and communications costs led the banks to establish a shared facility, Charge Card Services Limited, for the operations of Bankcard (Bankcard Association of Australia, 2009).

2 Constraints on charges on borrowing included rules controlling credit card operations, particularly the near uniform State Credit Acts enacted in five Australian States following the 1972 Molomby Report (Prices Surveillance Authority, 1992, p. 135). These Acts prohibited the charging of fees and interest beyond a credit charge on outstanding balances based on a fixed annual interest rate. They were only amended following a 1992 Prices Surveillance Authority report that identified problems with the profitability of credit card operations for banks. 
The early operations of Bankcard raised some concerns about collusion; as I explain below, banks would not give NBFIs access to Bankcard and an agreement existed between banks about the final prices charged for Bankcard to merchants and cardholders. In 1976, credit unions in Australia sought access to the Bankcard network, however, negotiations for them to obtain this broke down in 1978. Building societies and credit unions responded by introducing the Visa Debit card in 1982 (St George Bank, Bendigo Bank, Australian Association of Permanent Building Societies and Credit Unions Services Corporation, 2001, p. 8; Australian Retailers Association, 2002, p. 13). In 1980, the Trade Practices Commission issued a determination regarding an application for the authorisation of aspects of interbank agreements for the Bankcard network (Australian Financial System Review [the Campbell Report], 1981, para. 32.20 and footnote 5). The agreements were authorised subject to amendments to: (i) allow member banks to participate in any other card network; (ii) allow member banks to make their own decisions on prices and terms faced by merchants and cardholders and (iii) remove any agreement between banks in relation to a No-Surcharge Rule for merchants.

In spite of the concerns created by Charge Card Services Ltd, a number of other jointventures were set up in Australia to develop retail payment systems. In the mid-1970s, the Australian banks set up Central Magnetic Tape Exchange ("CEMTEX") to process their direct entry payments centrally (Reserve Bank of Australia, 1997, para. 64). In 1977, following the first ATM network in Australia being introduced by a major bank, Westpac, credit unions began development of a shared ATM network in Queensland (Sager, 1989, p. 251; Australian Science and Technology Council, 1986, p. 26). In 1983, the permanent building societies created a central facility for processing direct entry, ATM and EFTPOS transactions when they created Cashcard Australia Limited (Reserve Bank of Australia, 1997, para. 64; First Data Corp., 2003, December 22). In 
1984, the credit unions established AUSTNET, a switch offering ATM and EFTPOS services for holders of the credit unions' Redicard (Australian Science and Technology Council, 1986, p. 26). Bankcard, itself, entered into joint-venture arrangements in Visa and MasterCard, but these were discontinued in 1981, leading to Visa and MasterCard launching credit cards into Australia in 1984 (Weekes, 2006, February 3). (After that failed attempt, BankCard always lacked the international acceptance of Visa and MasterCard payment instruments, leading to banks withdrawing it as a product in 2006 (Brammall. 2006, February 3).

\section{Reviews of Australia's financial industry}

In 1979, the Australian Federal Government established the Australian Financial System Inquiry to prepare what became known as the Campbell Report (named after the Committee's chairman, Keith Campbell). Up until that time, Davis (1984, p. 135) says "the structure of financial regulation in Australia had remained virtually unchanged for several decades." The Report was an endorsement of a massive process of deregulation, involving an end to most direct controls of banks, the floating of the exchange rate and the entry of foreign banks (Davis, 2003, p. 2). In regard to retail payment systems, the Report recommended (paras. 23.53-23.54) that, to ensure "the features of security and reliability of the core segment of the payments system, and the community's general confidence in it," cheques continue to only be issued by banks. Davis (1984) describes this recommendation, and others involving distinctions between banks and NBFIs, as being based on the past regulatory environment and unsupported by analysis of potential arguments in the distinction's favour. The Campbell Report did not, however, recommend that there be any other restrictions on participation in payment systems (including not on cheque issuance by way of an agency relationship). 
In May 1983, the Federal Government appointed what became known as the Martin Review Group, named after Chairman, V.E. Martin, to review the Campbell Report in light of the then Labour Government's economic and social policies and the need to improve the efficiency of the financial system (Australian Financial System Review Group [the Martin Review Group Report], 1984, para. 1.1). The Group reported late in 1983, endorsing the broad views of the Campbell Report and making further recommendations regarding the regulation of banks, banking participation and payment system access. Following those recommendations, the Government removed virtually all restrictions on bank lending (Tyree, 2001, p. 41; Martin Review Group Report, Chapter 5) and invited applications from foreign banks for four to six new bank licences (House of Representatives Standing Committee on Finance and Public Administration, 1991, para. 2.81). However, 16 applications were accepted in 1985, "much to the dismay of some applicants who had been confident they would have been included in a smaller number" (ibid). At para. 2.31, the Martin Review Group Report effectively endorses the approach of the Campbell Report in regard to cheque clearing. It states that the Group did not "advocate permission for payment orders or cheques drawn on NBFIs to be cleared through the clearing system, either by themselves of by banks, because of the importance that it attaches to maintenance of full confidence in the clearing system." In 1986, the Australian Government passed the Cheques and Payment Orders Act, which required that cheques continued to be drawn on a bank. It did introduce the concept of a payment order, a cheque in all respects save that it was drawn on a building society or credit union, although these never gained widespread usage (Tyree, 2001, p. 42).

The Martin Review Group Report made two other important recommendations about the development of new retail payment systems. The first was that NBFIs be encouraged to participate in CEMTEX, the organisation created by banks to centrally 
process interbank transfers (the Martin Review Group Report, paras, 4.12-4.14, p. 197). Although I have not found sources arguing why it happened, the banks reacted by disbanding CEMTEX in 1984 and exchanging transaction information bilaterally (Financial System Inquiry [the Wallis Report], pp. 631-632). Building societies and credit unions established their own direct clearing networks through their industry organisations (Australian Payments Clearing Association, 1996, p. 43). The Martin Review Group Report recommended (paras. 6.1-6.5) the creation of the Australian Payments System Council to facilitate a joint, participatory approach to retail payment system development. In June 1984, the Federal Government followed this recommendation and established the Australian Payments System Council to advise the Treasurer on the development of payment systems and act as a forum for discussing payment system problems (Dean, 1988, 15 July; the Wallis Report, p. 385; Tyree, 2001, p. 42). It was chaired by the RBA and had broad industry and consumer representation. Tyree says that " $[\mathrm{r}]$ ecords of its early years show that discussion centred almost exclusively on access to networks".

Development with threatened property rights: EFTPOS and the Australian Payment Clearing Association

In 1984, the banks also took over their own data capture and processing for Bankcard transactions from their joint venture, Charge Card Services Ltd (Prices Surveillance Authority, 1992, p. 10). The Bankcard website attributes this development to improvements in technology, although the Prices Surveillance Authority report was not convinced (pp. 36-39) by this rationale, pointing to trends in the UK towards third party, rather than in-house, processing of credit card transactions. In 1987, Charge Card Services was renamed Cardlink Services Limited and used to reduce the cost of credit 
card transaction processing by Australian banks (Cardlink Services Limited, 2009; Credit card imaging, 1996, November 21).

The first EFTPOS trial I have found records of was run by Whyalla Credit Union and G J Coles (which became the major department store chain, Coles Myers) and began in South Australia in June 1982 (Australia Science and Technology Council, 1986, para. 6.2.2). This was followed by a number of other bank and NBFI trials. The pilots continued, although there was initially no interchange of transactions between them. One pilot's terminals could not accept transactions made using another's cards. This started to change from 1985, when bilateral agreements began to be negotiated, allowing network interconnection (Australian Competition Tribunal, 2004 [ACompT 7], para. 37). A closed or 'gateway' approach was developed with banks providing merchant terminals, switching transactions from terminals and receiving and settling funds from the issuer. This type of system was "strongly advocated" by the four major Australia banks (Australia Science and Technology Council, 1986, paras. 4.4.3-4.4.4; Gyoery and Seberry, 1987, p. 11). In spite of the Australia Science and Technology Council arguing it gave the gateway bank "a good deal of control over the total process" and NBFI and retailer preferences for an open system, a closed system became the norm for the Australian debit card payment system.

As part of the bilateral agreements for interconnection, the payment of negative interchange fees was instituted to provide acquirers with "some return on the considerable investment required to implement and maintain a secure, on-line, real time acquiring infrastructure" (ACompT 7, para. 38, quoting the evidence of Mr Charles Gove). In 2000, 39 interchange agreements were counted, all involving the payment of negative interchange fees with the majority of fees between $\mathrm{A} \$ 0.18$ and $\mathrm{A} \$ 0.25$ (Reserve Bank of Australia and Australian Competition and Consumer Commission 
[the Joint Study], 2000, p. 61). Those organisations without bilateral agreements for EFTPOS, but wishing to offer their customers EFTPOS services, were able to do so by making use of a 'gateway service', which provides links to other EFTPOS service providers for a fee of A $\$ 0.10-0.15$ per transaction (the Joint Study, 2000, p. 62). The need for merchants to invest in EFTPOS terminals eventually led larger merchants to negotiate the payment of fees from acquirers, with the first such agreement reached in 1991 (ACompT 7, para. 42). ${ }^{3}$ The Prices Surveillance Authority (1995, p. 271) describes the MSF for EFTPOS transactions as ranging from slightly more than a nil charge to A $\$ 0.95$ for one small retailer. The Authority reported that the average charge was between $\mathrm{A} \$ 0.01$ and $\mathrm{A} \$ 0.15$, but that most small retailers paid between $\mathrm{A} \$ 0.20$ and A $\$ 0.30$ per transaction. The Payments System Board (2007, pp. 26 - 27) says however that the average MSF for EFTPOS transactions in 2006 was $-\mathrm{A} \$ 0.02$, reflecting the part payment of negative interchange fees by acquirers to larger merchants. It is not clear that the Prices Surveillance Authority included such interchange fee payments in its calculations. The Authority does provide (p. 62) evidence of the fees paid by cardholders in 1995, with half the banks charging cardholders no fee and the others charging a transaction fee of $\mathrm{A} \$ 0.20-0.50$, typically after a limited number of free transactions. Finally, the Authority's report also states (p. 277) that a No-Surcharge Rule exists in agreements between merchants and banks governing the provision of EFTPOS transaction services, although I have found no evidence of its continued use.

During the late-1980s and early-1990s, concerns about the banking industry led the Australian Parliament to create a committee to examine industry issues and the House of Representatives Standing Committee on Finance and Public Administration

3 By 2004, half of all EFTPOS transactions were completed using terminals and PIN pads owned by merchants (ACompT 7, para 45). 
published its report, the Martin Parliamentary Committee Report, in $1991{ }^{4}$ Specifically, the concerns related to perceptions of the excessive profitability of banks and of whether banking customers were seeing the benefits of an increase in competition (Martin Parliamentary Committee Report, paras. 1.1-1.4). The Report recommended the completion of a feasibility study of direct payments system access for NBFIs and a formal Prices Surveillance Authority brief to examine the profitability of the credit card business (Wallis Report, p. 573). In 1992, the Authority released its report, Inquiry into Credit Card Interest Rates. The report made a number of recommendations modifying controls on credit cards. Specifically, it recommended that the State Credit Acts, which had been introduced from 1972 to regulate credit cards in the Australian states (Wallis Report, p. 570), be amended to allow networks to charge cardholders fees beyond just a credit charge, allow merchants to surcharge credit card transactions. The report also recommended that the RBA take over the "long term monitoring" of banks' credit card products. Following this report, State Credit Acts were amended to allow differential pricing structures for credit cards, but were not amended to prevent credit card networks' imposition of the No-Surcharge Rule (the Joint Study, 2000, p. 54).

At approximately the same time, the banking industry responded to similar concerns about fees and access to payment systems and an executive committee of the Australian Bankers' Association recommended that an independent organisation be established to oversee Australia's payment systems (Spencer, 1991, pp. 44-46). This eventually led to the creation of the Australian Payment Clearing Association, which was incorporated as a public company in 1992. At that stage, the banks accounted for $72 \%$ of the assets of financial intermediaries in Australia with just four banks making up three quarters of the

4 I distinguish this report, the Martin Parliamentary Committee Report, from the Martin Review Group Report, which was published in 1983. 
banking industry (Martin Parliamentary Committee Report, p. 25 and para. 2.86). The dominance of this small group of banks suggests it was difficult for other financial intermediaries to take a different approach. Indeed, in 1994, the Australian Payment Clearing Association absorbed the operations of the direct entry systems of building societies and credit unions, as well as the banks' bilateral direct entry system that was introduced followed the disbandment of CEMTEX (Australian Payment Clearing Association, 2009, p. 10; Wallis Report, pp. 631-632). In particular, the Association became responsible for the Bulk Electronic Clearing System, which is used for the processing of direct entry transactions, and the Consumer Electronic Clearing System, which is used for ATM and EFTPOS transactions. While involved in the setting of standards, however, members of the Association are not immediately able to exchange transactions with other members as they still required bilateral interchange agreements with other members before this could occur.

Continued consumer dissatisfaction with bank fees, particularly those charged for account services, led to the publication of another report by the Prices Surveillance Authority in 1995. As well as surveying bank account fees, the Prices Surveillance Authority was asked to consider EFTPOS interchange fees and the pricing principles of Visa and MasterCard in relation to debit cards in Australia. In addition to completing these surveys, the Authority recommended that State and Territory Governments enact legislative changes to remove legal barriers to NBFIs being able to provide a full range of banking services.

However, in spite of the creation of Australian Payment Clearing Association, problems persisted with access to retail payment systems. For example, the final report of the Financial System Inquiry, published in 1997, (which became known as the Wallis Report) expressed concerns about access for acquirers to the EFTPOS system (p. 398): 
... confidential information provided to the Inquiry demonstrates that the relative negotiating strength of major merchant acquirers and card issuers over interchange fees is uneven and that regional banks have been frustrated in their efforts to gain access to the EFTPOS network as acquirers.

\section{Other developments: stored-value payment systems}

In 1995/96, four trials of stored value cards were run in Australia: two (Quicklink and Transcard) had transport applications and were run by local companies; while the others represented the world's first stored value card trials by Visa and MasterCard (Clarke, 1997, p. 48). While being technically feasible, however, the trials were met with mixed success; they failed to realise sufficiently high adoption rates to be economically feasible (Clarke, 1997, p. 50).

\subsubsection{A New Approach to the Regulation of Banks}

\section{The Wallis Report}

In 1996, the Government established another Financial System Inquiry, which produced the Wallis Report, named after the Inquiry Chairman, Stan Wallis, in March 1997. The inquiry conducted further investigations of the state of Australia's financial industry regulation and its final report recommended regulations on the basis of function rather than of status - it called for the creation of a new financial entity, the Authorised Deposit-taking Institution, in place of the legal concept of a bank (Tyree, 2001, pp. 4244). ${ }^{5}$ The Wallis Report also recommended changes to authorities regulating banks and retail payment systems: the creation of the Australian Prudential Regulatory Authority with responsibilities for prudential supervision, previously exercised by the RBA, and the disbandment of the Australian Payments System Council with its functions being taken on by the Payments System Board, to be created within the RBA. The latter

5 In spite of the creation of the legal entity, Authorised Deposit-taking Institution, Beatty, Aubrey and Bollen (1998, pp. 504-512) outline the significant controls that continued to exist around organisations' use of the words bank, building society and credit union. 
recommendation was made following concerns expressed in the Wallis Report about the efficiencies of, and, as discussed above, access to, Australian payment systems (p. 398). In regard to efficiency, the Wallis Report noted concerns about retail payment system prices that had been expressed by the Australian Payments System Council and in the 1992 Prices Surveillance Authority report. Finally, the Wallis Report recommended that all forms of payment instrument storing value be subject to regulation (the Wallis Report, 1997, p. 406).

As its first response to the report, the Australian Government passed a series of 12 bills into law during 1998 (Australian Treasury, 1998, p. 19). ${ }^{6}$ The package included new legislation and amendments that opened access to retail payment systems (by, for example, allowing NBFIs to issue cheques), but requiring that issuers of payment instruments, including stored-value instruments, ${ }^{7}$ be an Authorised Deposit-taking Institution regulated by the Australian Prudential Regulatory Authority or otherwise be authorised by the RBA “(in which case further regulation may be required)" (Australian Treasury, 1998, p. 23). Furthermore, the Australian Government passed the Payment Systems (Regulation) Act 1998, which created the Payments System Board within the RBA to control risk in the financial system while promoting efficiency and competition. $^{8}$ Assistant Governor of the RBA, Dr. Philip Lowe, has said (Lowe, 2005, May, p. 269) that the RBA's new role came as a surprise: “[w] had not been arguing for an extension of our powers, and we had not been seeking responsibility for payments system efficiency." Some commentators initially expected the RBA not to take an interventionist stance towards retail payment systems, given its "long history of

6 The Government's second response was to transfer to federal authorities regulatory responsibilities for financial entities previously held by Australia's States and Territories.

7 Issuers of such instruments are treated as a special type of ADI, known as a Purchased Payment Facilities Provider, subject to specific prudential requirements (Australian Prudential Regulatory Authority, 2008).

8 To avoid confusion, this thesis will refer to the views and actions of the RBA, rather than to those of the PSB, specifically. 
pursuing a soft approach to regulation" (Tyree, 2001, p. 48). However, Davis (2003, pp. 8-9) was less surprised, saying that the RBA's direct involvement with the banking sector had reduced in recent years, particularly with the devolvement of prudential supervision to the Australian Prudential Regulatory Authority; he also describes the RBA's increasing independence from the Australian Federal Government, suggesting that the RBA was more willing to act in a controversial manner.

\subsubsection{Payment System Development Following the Reforms}

The Wallis Report recommended legislative changes that gave both a new approach to the regulation of banks and gave the RBA an ability to intervene in the operations of retail payment systems, which the RBA strongly indicated it would exercise within 2 years. This leaves only a short time period involving development after the reforms, but before the RBA began intervening in system operations, in which I have identified only one important development event. Since payment networks may well have been anticipating interventions, however, it is difficult to argue that this event occurs strictly before the influence of interventions. Nevertheless, I keep to my chronological approach and describe it as such. In November 1997, a new bill payment service, BPAY, was launched in Australia (BPAY website, 2010). BPAY is owned by Cardlink Services Ltd, the company that, as described above, was originally set up to centrally process Bankcard transactions. At the time of BPAY's introduction it was owned by the four major banks as well as the Bank of Western Australia. BPAY operated under an open access regime and, in 2011, reported on its website that "[n]ow, over 170 Australian financial institutions, ranging from banks to credit unions and covering about 90 per cent of the consumer banking market, belong to the scheme.". 


\subsubsection{Interventions in Retail Payment Systems}

In creating the Payments System Board within the RBA, the Government envisaged it intervening only "when the scope for voluntary reform had effectively been exhausted" (Lowe, 2005, March 2, p. 11). However, the legislation it provided few avenues for appeal against the RBA's decisions. In 2000, the RBA and Australia's competition regulator, the Australian Competition and Consumer Commission, satisfied another recommendation of the Wallis Report by completing the Joint Study, which investigated the efficiency of debit card, credit card and ATM networks. The Joint Study raised a number of concerns related to retail payment systems, including that interchange fees encouraged the use of credit cards, which, according to the Study, were a more expensive payment instrument. The RBA subsequently intervened to reduce or correct those issues the Study had identified. To account for the RBA's actions, Dr. Lowe later detailed five benchmarks against which the RBA judged efficiency and competition (Lowe, 2005, March 2, pp. 9-10):

(i) relative prices reflect the relative resource costs;

(ii) merchants are free to choose the price they charge for accepting payment instruments and are free to choose which instruments they accept;

(iii) prices are transparent;

(iv) restrictions on access are limited to those strictly necessary for the safe operation of the system; and

(v) there is competition within and between individual payment systems.

\section{Regulation of credit cards}

In its first act of intervention, the RBA 'designated' the four-party credit card networks that were in Australia at that time (Visa, MasterCard and Bankcard) as being under its regulation. ${ }^{9,10}$ Visa and MasterCard were unsuccessful in a challenge to the RBA's

9 Designation is required by the Payment Systems (Regulation) Act 1998 before imposition of "standards", rules for the operation of payment systems. 
decision in the Federal Court on procedural and jurisdictional grounds and the RBA introduced interchange fee regulation and removed the No-Surcharge Rule existing for credit cards during 2003, before imposing minimum entry standards during 2004 (Chang, Evans and Garcia Swartz, 2005, pp. 332-333).

The RBA mandated that interchange fees for Bankcard, Visa and MasterCard must fall from approximately $0.95 \%$ to approximately $0.55 \%$ (Reserve Bank of Australia, 2007a, para. 129). This flowed through to average MSFs for Bankcard, Visa and MasterCard falling from approximately $1.4 \%$ in 2003 to approximately $0.8 \%$ in 2007 (Reserve Bank of Australia, 2007a, p. 22). The RBA initially estimated this saved merchants A $\$ 430$ million, annually (Reserve Bank of Australia, 2004, p. 12). However, Chang et al (2005, p. 339) find that issuers regained $30-40 \%$ of the reduction in interchange fee revenue by increasing fees to cardholders in the months that followed the new regulations. Chang et al also find that cardholder fees have mainly been increased through higher fixed fees, making little difference to cardholders' per-transaction fees or benefits, contrary to the RBA's intention of encouraging relative prices to reflect relative resource costs. ${ }^{11}$ They say it's difficult to predict the decrease in use of credit cards that would likely come from an increase in fixed fees. Further difficulties in assessing the effects of the reforms are caused by banks changing the nature of the products they issue. For example, banks started issuing products more likely to cause cardholders to borrow on their cards and revolve positive balances (Simon, 2005, p.

10 Simon (2005, p. 376) describes how, slightly prior to the designation of the four-party payment schemes, the Australian Competition and Consumer Commission was conducting an investigation into the legality of the practice of agreeing an interchange fee represented fixing MSFs.

11 Reserve Bank of Australia (2007a, para. 95) does point to a reduction in cardholder reward schemes, by reporting that, in 2003, consumers were required to spend $A \$ 12,400$ on a standard credit cards of major Australian banks in order to receive an A $\$ 100$ voucher. In 2007, they were required to spend A $\$ 16,200$, which it argued was effectively a $0.2 \%$ increase in the price of a credit card transaction for consumers. Chang et al (2005, pp. 339-340) respond, however, that this change has largely come from a cap on rewards and, for most consumers, will no`t have had much effect on the marginal incentive to use a credit card. 
379). They also started making "serious, and predictable" attempts to shift cardholders, particularly high spending cardholders, from regulated four party credit card networks to the unregulated three-party networks, American Express and Diners Club, the cards of which they had started issuing (Chang et al, 2005, p. 340). ${ }^{12}$ Although MSFs for these cards had also fallen following the RBA's reforms, they had decreased less than, and remained significantly above, the fees for the Visa and MasterCard networks. Furthermore, Chang et al believe that:

[t]he RBA's hope that regulating the associations' interchange fees would exert substantial downward pressure on the American Express and the Diners Club merchant discount rates is particularly unlikely to be realized as high-spend rewards cardholders move to the unregulated systems.

The reforms also caused the No-Surcharge Rule of the Visa and MasterCard networks and the equivalent American Express and Diners Club rules to be abandoned. The Payments System Board Annual Report (Reserve Bank of Australia, 2007b, p. 25) provides a graph that shows an increasing amount of surcharging with $17 \%$ of very large merchants and approximately $5 \%$ of very small merchants imposing a credit card surcharge in June 2007, although the Report does not clarify if the surcharging relates to Visa and MasterCard or to American Express and Diners Club or to both. More critical of the intervention in the setting of the No-Surcharge Rule by the RBA is Visa's Submission to the 2007-2008 Review (Visa, 2008). Referring to the analysis of Stillman, Bishop, Malcolm and Hildebrandt (2008, p. 28), Visa notes that surcharges often exceed the marginal cost of accepting cards for merchants.

\section{Regulation of other retail payment systems}

\footnotetext{
12 Chang et al also comment (pp. 329-330) that American Express reached an agreement with AMP for the latter to issue its cards in 1998. However, it "more prominently" reached issuance agreements with major banks following the RBA's reforms.
} 
In an effort to deal with concerns about interchange fees shown by the RBA, a working group, composed of industry participants, released a discussion paper in 2002 regarding reform of interchange arrangements of, and access to, Australia's EFTPOS system (EFTPOS Industry Working Group, 2002). In the following year, a group of banks voluntarily approached the Australian Competition and Consumer Commission and offered to set the interchange fee for EFTPOS transactions to zero in an effort to forestall the regulation of EFTPOS fees (ACompT 7, paras. 8, 17). The Australian Competition and Consumer Commission eventually authorised the agreement after it became satisfied that its concerns about access would be adequately addressed. However, a group of merchants appealed the Australian Competition and Consumer Commission's decision to the Australian Competition Tribunal, which found in the merchants' favour, setting aside the Australian Competition and Consumer Commission's authorisation. According to the RBA, this effectively ended the prospect of voluntary reform. After "... noting that there was there was little further prospect of industry reform of interchange fees", the RBA "designated" the EFTPOS system for regulation and imposed a standard for interchange fees in 2004 (Reserve Bank of Australia, 2006, April, p. 4). Merchants also challenged the RBA's decision to designate EFTPOS in the Federal Court, although the challenge was ultimately unsuccessful (Reserve Bank of Australia, 2006, April, p. 3).

In an effort to reduce the delay associated with this second challenge, the RBA released draft standards for EFTPOS and Visa Debit interchange fees and the use of the HonourAll-Cards Rule in February 2005 (Reserve Bank of Australia, 2006, April, p. 4). However, the challenge represented a barrier to a final decision on the standards, until the Federal Court found in favour of the RBA in November 2005 and standards were imposed on the systems in November 2006 (Payments System Board, 2007, p.22). The standard imposed required negative interchange fees for EFTPOS transactions without a 
cash-out component to be between A $\$ 0.04-0.05 .{ }^{13}$ MSFs for Visa Debit had historically been the same as those for credit card transactions, prior to the RBA's credit card reform, at approximately $0.95 \%$. The RBA implemented a cost-based positive interchange fee standard of $\mathrm{A} \$ 0.12$. Since Visa debit cards still operated with positive interchange fees and EFTPOS with negative, MSFs for EFTPOS transactions remained lower following the RBA's new standard. In 2010, supermarket chain, Woolworths, announced it would route transactions made using Visa or MasterCard debit cards over the EFTPOS network, thereby incurring lower MSFs, but causing some customers to incur higher per-transaction fees for their transactions and thereby attracting some complaints from customers (Woolworths Limited, 2010, April 1; Mitchell, 2010, April 17).

The average MSF for EFTPOS transactions, which, in the period leading up to the standard's introduction, had been approximately $\mathrm{A} \$ 0.02$, had risen to approximately A $\$ 0.08$ by 2007 (Payments System Board, 2007, p. 26). However, the change in pricing appears to have had limited effect on pricing to cardholders. Payments System Board (2007, p. 28) says that "all-you-can-eat" accounts (which have no transaction fees) were becoming more popular following the reforms, in spite of evidence that half of surveyed banks offered such accounts in 1995 (Prices Surveillance Authority, 1995, p. 62).

As well as the draft standards for EFTPOS and Visa Debit, the RBA's 2005 report also analysed the use in Australia of the Honour-All-Cards Rule. It saw benefits for consumers of the honour-all-issuers aspect of the rule (which holds that merchants

13 Because it had yet to regulate interchange fees for ATM transactions, the RBA decided not to impose a standard for EFTPOS transactions involving cash-outs (Reserve Bank of Australia, 2008, p. 22). However, the RBA found that some interchange fees for cash-out transactions had fallen, while others remained at previous levels (Reserve Bank of Australia, 2007, p. 22). 
accepting a scheme's cards are required to accept all cards issued by members of that scheme). The RBA was concerned, however, that the honour-all-products aspect (which holds that merchants accepting one sort of a scheme's cards are required to accept all cards issued no matter the type of card) was detrimental to competition between Visa Debit and EFTPOS. It says that (p. 41) Visa Debit "has a competitive advantage over EFTPOS because merchants are forced to accept the card when they make the decision to accept Visa credit cards and must pay a higher price to do so than with EFTPOS." The RBA threatened to remove the rule by direct regulation unless Visa voluntarily abandoned the rule and, when Visa failed to do so, directly removed it with effect from 1 January 2007 (Reserve Bank of Australia, 2006, July 7).

In 2005, the RBA announced that there was not a strong case to regulate BPAY's interchange fee, called a Capture Reimbursement Fee (Reserve Bank of Australia, 2007a, paras. 56-57). It noted that this fee was reviewed regularly, had fallen steadily and was expected to fall further. The RBA also found that a regulated reduction in the Capture Reimbursement Fee would likely lead to higher costs for consumers, encouraging greater use of more costly bill payment systems.

\section{A continued interest in regulating retail payment systems}

In 2006, the RBA announced it would review the effects of its reforms in what became known as, the 2007/08 Review. In order to provide a basis for the review, the RBA published an Issues Paper in May 2007. In its paper discussing the conclusions to its review (Reserve Bank of Australia, 2008), the RBA said it had considered three broad options in its approach to interchange fee regulation, to retain regulations leaving the fee standards unchanged, to retain regulations reducing fee standards or to step back from regulation. Although it said that competitive conditions had improved and its 
preference was to deregulate interchange fees, the RBA was concerned about the risk that interchange fees would rise, possibly substantially, if it did so.

In a submission for American Express to the 2007/08 Review, ACIL Tasman discusses provisions of in-store finance products (such as those offered by GE Money) that contain rules that effectively amount to a No-Surcharge Rule, thereby questioning the consistency of the RBA's approach. Furthermore, ACIL Tasman argued that the removal of the No-Surcharge Rule amounted to increasing the barriers to entry and expansion for new and existing retail payment systems. Added to this factor, ACIL Tasman quotes a February 2007 article in the magazine, Cards International, that said:

There is ... evidence that major offshore card issuers have bypassed the Australia market because of the protracted nature of the RBA reforms, preferring to enter markets where conditions appear more stable.

In spite of these concerns, new products have been introduced to the Australian market, including contactless Visa and MasterCard cards and a MasterCard-branded debit card. In February 2006, American Express and major Australian airline, Qantas, launched a range of Qantas American Express credit cards (Country survey - Australia: Reforms lead to new revenue hunt, 2006, July 15). Australia's banks continued to trial StoredValue Card products during the late 2000s, including one trial that involved Visa, a major bank and a major mobile phone company cooperating to introduce Australia's first mobile phone-based payment system (Telstra, NAB and Visa to develop an Australian first, 2007, August 30). The trials included significant deployments of readers to merchants. However, their outcomes have yet to be reported.

In its conclusions to the 2007/08 Review, the RBA said developments that might allay its concerns about payment systems and allow it to step back from regulation, included banks making enhancements to Australia's EFTPOS system and credit card networks making voluntary undertakings that, if deregulated, interchange fees would not rise 
above their current levels (Reserve Bank of Australia, 2008, p. 19-20). During 2009, Australian Payment Clearing Association established EFTPOS Payments Australia Limited with commercial responsibilities for managing and promoting EFTPOS. Also in 2009, the banking industry announced that it was reinitiating an inter-bank, personto-person retail payment system called MAMBO, which, as I describe below, had been abandoned in 2008. In August 2009, however, the RBA announced that the industry had not made sufficient progress towards its suggestions and regulation would be retained (Reserve Bank of Australia, 2009, August 26).

In 2009, the RBA announced a regulatory framework for the county's ATM system, saying that it saw an approach of charging foreign fees for ATM use as, "unjustified and against the spirit of the [RBA's] reforms" (Reserve Bank of Australia, 2009, February 24). It proposed an access regime that focussed on the price of access (including interchange fees) and bought greater transparency to cardholders. Specifically, the regime, which was to be implemented in March 2009, provided for direct charging by prohibiting the payment of interchange fees between ATM owners and consumer account providers and requiring that ATM owners be compensated only by a fee being paid by consumers accessing foreign ATMs, a fee to be clearly shown to consumers as they completed a transaction. Tthe RBA also commented about regulating Paypal in its media release announcing a new regime for ATMs. The RBA said it felt that Paypal's use of the No-Surcharge Rule was detrimental to the efficiency of Australia's payments system. However, it added that Paypal was still a "relatively small player in the online market" and it considered that "it was not convinced that the benefits of imposing regulation to remove the rule would outweigh the costs." Still, the RBA said it might change that assessment if Paypal grew significantly and merchants grew less able to refuse to accept it. 
In 2008, the inter-bank bill payment network, BPAY confirmed it was developing an online banking project, MAMBO (Me And My Bank Online) (Palmer, 2008, May 5). MAMBO allowed BPAY customers to use their individual BPAY codes to establish other payments, such as direct debits, allowing them to change banks more easily by keeping the same BPAY code. Later that year, however, the major Australian banks, who were owners of BPAY, asked the company to end its development of the project (Cane, 2008, November 13). In response to RBA suggestions of what would help it step back from interchange fee regulation, however, the project was reinitiated in 2009. However, in spite of the development of MAMBO continuing even after the RBA's announcement that regulation would be retained, issues with its development also remained. One bank vetoed a MAMBO innovation that would have seen email addresses and mobile phone numbers being used to identify customers receiving payments (Cane, 2010, April 22). However, development in the "long-running" project has not this time been shelved and significant investment appears to continue (Palmer, 2010, October 21).

The RBA indicated it was willing to review aspects to its regulation of Australian retail payment systems when it announced it would review innovation in the industry in thie middle of 2010 (Reserve Bank of Australia, 2010, July 22). The RBA’s media release on the review indicated it would look at whether "innovation in the Australian payments system may be improved through more effective co-operation between stakeholders and regulators." The release also said the goal is "ultimately to identify projects that the Bank [the RBA] and other stakeholders could work on co-operatively to enhance the payments system in Australia." These statements indicate the RBA's willingness to reconsider its approach to regulation. However, the extent to which it does so remains to be seen. 


\subsubsection{Data Showing Payment Instrument Adoption in Australia}

For my analysis of retail payment system adoption in Australia, I obtain data on the volume of transactions from the Reserve Bank of Australia (2010a). The data covers issued transactions for cards issued by reporting institutions, which are "Australian banks, foreign banks operating in Australia, and most building societies and credit unions." I supplement it with data on Australia's estimated residential population from the Australian Bureau of Statistics (2010). In a discussion of series breaks in its statistics, Reserve Bank of Australia (2010b, p. 9) says a break was caused in January 2002 by changes in definitions, particularly with the inclusion of statistics on the usage charge cards. Furthermore, debit card statistics from Reserve Bank of Australia (2010) distinguish cash-only transactions from other transactions only from July 2002 onwards, all types of transactions being included in a total before this date. Given my focus on transactions completed for purchases, I do not include data for Australia prior to 2003 in Figure 1.1.

\subsubsection{Bibliography for Summaries of Australia}

Australian Bureau of Statistics. (2010). Table 4. Estimated resident population: States and territories (number). 3101.0 Australian demographic statistics, Retrieved from http://www.abs.gov.au/AUSSTATS/abs@.nsf/DetailsPage/3101.0Jun\%202010?OpenD ocument

Australian Competition Tribunal [ACompT 7]. (2004). Re EFTPOS Interchange Fees Agreement

Australian Financial System Review [the Campbell Report], (1981). Final report of the Committee of Inquiry, September 1981, Canberra: Australian Government Publishing Service

Australian Financial System Review Group [the Martin Review Group Report]. (1984). Report of the Review Group, Presented 21 December 1983, Canberra: Australian Government Publishing Service

Australian Payments Clearing Association. (1996). Submission to Financial System Inquiry, September 5, Retrieved from http://fsi.treasury.gov.au/content/downloads/PubSubs/000033.pdf 
Australian Payments Clearing Association. (2009). 2009 annual review, Sydney: Australian Payment Clearing Association, Retrieved from http://www.apca.com.au/AR2009/pdf/apca_2009_annual_review.pdf

Australian Prudential Regulatory Authority. (2008). Prudential Standard APS 610: Prudential requirements for providers of Purchased Payment Facilities, Retrieved from http://www.apra.gov.au/ADI/upload/Final-APS-610-November-2007.pdf

Australian Retailers Association. (2002). Submission to Reserve Bank of Australia: Response to EFTPOS industry working group, September 13, Retrieved from http://www.rba.gov.au/payments-system/reforms/debit-card-systems/responses-discpaper/ara-130902.pdf

Australian Science and Technology Council. (1986). Towards a cashless society? A report to the Prime Minister, Canberra: Australian Government Publishing Service

Australian Treasury. (1998). Reform of the Australian financial system. Economic roundup, Winter 1998, 19-23. Retrieved from http://www.treasury.gov.au/contentitem.asp?ContentID=199\&NavID=016

Bankcard Association of Australia. (2009). History. Retrieved on 2009, November 7 from http://www.bankcard.com.au

Beatty, A., Aubrey, M. \& Bollen, R. (1998). E-payments and Australian regulation. University of New South Wales law journal, 21(2), 489-513

BPAY. (2011). BPAY company website: The BPAY story. Retrieved on 2011, April 13 from http://www.bpay.com.au/about/company_history.aspx

Brammall, B. (2006, February 3). Bankcard bites the dust - outmoded icon to be phased out. Hobart Mercury

Cardlink Services Limited. (2009). Our history. Retrieved on November 30, 2009 from http://www.cardlink.com.au/cardlink_history.htm

Cane, E. (2008, November 13). Payments innovation stalls, starting with project MAMBO. Online banking review, Retrieved on May 19, 2010 from http://www.bankingreview.com.au/2008/11/payments-innovation-stalls-starting-withproject-mambo.html

Cane, E. (2010, April 22). Facebook sets sights on payments, while banks debate M@MBO. Online banking review, Retrieved on May 19, 2010 from http://www.bankingreview.com.au/2010/04/facebook-sets-sights-on-payments-while$\underline{\text { banks-debate-mmbo.html }}$

Chang, H.; Evans, D. and Garcia-Swartz, D. (2005). The effect of regulatory intervention in two-sided markets: An assessment of interchange-fee capping in Australia. Review of network economics, 4(4), December,328-358

Clarke, R. (1997, April). Smart cards. Australian banker, 111(2), 48-51, Retrieved from http://www.rogerclarke.com/EC/SCBF.html

Credit Card Imaging. (1996, November 21). Australian Banking \& Finance 
Davis, K. (1984). Financial regulation in Australia. The Australian economic review, 17(3), 135-148

Davis, K. (2003). Financial reform in Australia. In Hall, M. (Ed.), The international handbook on financial reform, Cheltenham: Edward Elgar Publishing Limited, pp. 1-30

Dean, W. (1988, 15 July). A change is on the cards. Sydney morning herald

EFTPOS Industry Working Group. (2002). Discussion paper: Options for EFTPOS interchange fee reform, Retrieved from http://www.rba.gov.au/paymentssystem/reforms/debit-card-systems/eftpos-fee-reform.pdf

Financial System Inquiry [the Wallis Report]. (1997, March). Final Report, Presented 18 March 1997, Canberra: Australian Government Publishing Service

First Data Corp. (2003, December 22). First Data Corp. to acquire Cashcard Australia Limited, Press Release

House of Representatives Standing Committee on Finance and Public Administration, Parliament of the Commonwealth of Australia, [Martin Parliamentary Committee Report]. (1991). A Pocket Full of Change: Banking and Deregulation, November Canberra: Australian Government Publishing Service

Grenville, S. (1991) The evolution of financial deregulation. In Macfarlane, I. (ed.) The deregulation of financial intermediaries, Proceedings of a Conference, pp. 3-35

Gyoery, R and Seberry, J (1987) Electronic Funds Transfer Point of Sale in Australia, Crypto 86, Springer Verlag, Lecture Notes in computer science, 263, Retrieved on August 9, 2009, from http://www.uow.edu.au/ jennie/WEB/WEB6993/max/113_1987.pdf

Harper, I. (1991) Bank deregulation in Australia: choice and diversity, gainers and losers. In Macfarlane, I. (ed.) The deregulation of financial intermediaries, Proceedings of a Conference, pp. 63-86

Innis, M. (2006, February 15). Credit to the nation. The age, retrieved from http://www.theage.com.au/news/money/credit-to-thenation/2006/02/14/1139890721578.html

Lowe, P. (2005, March 2). Reform of the payments system. Reserve Bank of Australia bulletin, Address to Visa International Australia and New Zealand Member Forum, Werribee, pp. 9-18, Retrieved from http://www.rba.gov.au/publications/bulletin/2005/mar/pdf/bu-0305-3.pdf

Lowe, P. (2005, May). Payments system reform: The Australian experience, Paper presented at conference, Interchange fees in credit and debit card markets: what role for public authorities?, Federal Reserve Bank of Kansas City, Retrieved from http://www.kansascityfed.org/home/subwebnav.cfm?level=3\&theID=11322\&SubWeb= $\underline{10683}$

Mitchell, S. (2010, April 17). Woolies ploughs on despite hostile reaction to changes for debit cards. Australian Financial Review (Abstracts) 
Palmer, C. (2008, May 5). BPAY's top-secret MAMBO project. Online banking review, Retrieved on May 19, 2010 from http://www.bankingreview.com.au/2008/05/bpaystop-secret-mambo-project.html

Palmer, C. (2010, October 21). Bankers dance to Mambo. Online banking review, Retrieved on February 21, 2011 from http://www.bankingreview.com.au/2010/10/bankers-dance-to-mambo.html

Prices Surveillance Authority. (1992). Inquiry into credit card interest rates, Melbourne: Prices Surveillance Authority, Matter No. PI/92/5, Report No. 45

Prices Surveillance Authority. (1995). Inquiry into fees and charges imposed on retail accounts by banks and other financial institutions and by retailers on EFTPOS transactions, Melbourne: Prices Surveillance Authority, Matter No. PI/95/2, Report No. 65

Reserve Bank of Australia. (1997). Supplementary submission to the financial system inquiry, 13 January, published as Occasional Paper No. 15

Reserve Bank of Australia. (2004, July). Merchant service fees for credit cards. Reserve Bank of Australia bulletin, Retrieved from http://www.rba.gov.au/publications/bulletin/2004/jul/pdf/bu-0704-2.pdf

Reserve Bank of Australia. (2005, February 24). Reform of the EFTPOS and Visa Debit systems in Australia: A consultation document, Retrieved from http://www.rba.gov.au/payments-system/reforms/debit-card-systems/consult-docfeb05/consult-doc-feb05.pdf

Reserve Bank of Australia. (2006, April). Reform of the EFTPOS and Visa Debit systems in Australia: Final reforms and regulation impact statement, Retrieved from http://www.rba.gov.au/payments-system/reforms/debit-card-systems/impact-stmtapr06/impact-stmt-apr06.pdf

Reserve Bank of Australia. (2006, July 7). Reform of debit card systems in Australia: MasterCard Debit and Visa Debit, press release, Retrieved from http://www.rba.gov.au/media-releases/2006/mr-06-04.html

Reserve Bank of Australia. (2007a). Reform of Australia's payments system: Issues for the 2007/08 Review, Retrieved from http://www.rba.gov.au/paymentssystem/reforms/review-card-reforms/pdf/review-0708-issues.pdf

Reserve Bank of Australia. (2007b). Payments System Board annual report 2007, Sydney: Reserve Bank of Australia

Reserve Bank of Australia. (2008). Preliminary conclusions of the 2007/08 review, April, Retrieved from http://www.rba.gov.au/payments-system/reforms/review-cardreforms/pdf/review-0708-pre-conclusions.pdf

Reserve Bank of Australia. (2009, February 24). Payments system issues, media release number 2009-03, Retrieved from http://www.rba.gov.au/media-releases/2009/mr-0903.html 
Reserve Bank of Australia. (2009, August 26). Payment System Reform, media release 2009-18, Retrieved from http://www.rba.gov.au/media-releases/2009/mr-09-18.html

Reserve Bank of Australia. (2010a). Payment system statistics: Tables C1 and C5, Retrieved from http://www.rba.gov.au/statistics/tables/index.html\#payments_system

Reserve Bank of Australia. (2010b). Historical series breaks to statistical tables. Retrieved from http://www.rba.gov.au/statistics/tables/pdf/hist-series-breaks.pdf

Reserve Bank of Australia. (2010, July 22). Strategic review of innovation in Australia's payments system, media release, number 2010-14, Retrieved from http://www.rba.gov.au/media-releases/2010/mr-10-14.html

Reserve Bank of Australia and Australian Competition and Consumer Commission [the Joint Study]. (2000, October). Debit and credit card schemes in Australia: A study of interchange fees and access, Sydney: Reserve Bank of Australia, Retrieved from http://www.rba.gov.au/payments-system/resources/publications/payments-au/interchgfees-study.pdf

Sager, M. (1989). Competitive alliances with information technology - the Australian retail banking experience. Information technology and people, 5(4), 245-255

Simon, J. (2005). Payment systems are different: Shouldn't their regulation be too? Review of network economics, 4(4), 364-383

Spencer, H. (1991). Pacific perspective on competition and cooperation - Australia. Payment systems worldwide, 1(4), 41-46

St George Bank, Bendigo Bank, Australian Association of Permanent Building Societies and Credit Unions Services Corporation. (2001). Visa Debit Australia discussion paper, Submission to the Reserve Bank of Australia, September 2001

Stillman, R.; Bishop, W.; Malcolm, K. and Hildebrandt, N. (2008). Regulatory intervention in the payment card industry by the Reserve Bank of Australia: Analysis of the evidence. CRA International, Retrieved from http://www.crai.com/ecp/assets/Regulatory_Intervention.pdf

Telstra, NAB and Visa to Develop an Australian First. (2007, August 30). National Australia Bank media release

Tyree, A. (2001). The Australian payments system. Banking and finance law review, 17(1), October, 39-65

Visa. (2008). Submission by Visa Inc regarding the Payment System Board of the Reserve Bank of Australia's assessment in the Preliminary Conclusions of the 2007/08 Review. Retrieved from http://www.visaasia.com/ap/au/mediacenter/hottopics/includes/uploads/Visa_Inc_Submission.pdf

Weekes, P. (2006, February 3). Bankcard checks out - downfall on the cards. The age Weiner, S. and Wright, J. (2005). Interchange fees in various countries: Developments and determinants. Review of network economics, 4(4) 
Woolworths Ltd. (2010, April 1). Woolworths to move all debit transactions to the australian EFTPOS network, media release 


\subsection{Canada}

\subsubsection{Retail Payment Systems and Government Controls on Banking}

The development of new payment systems in Canada followed reasonably closely behind that of its neighbour, the US. The Diners Club card was introduced to Canada in 1951 and was followed by American Express and Carte Blanche in 1958 (Campbell, 1989, March 25). It was not until 1968 that the first bank-issued credit card became available when four banks cooperated to introduce the forerunner of Visa, BankAmericard, under the name, Chargex (Roseman, 2006, August 17). The forerunner of MasterCard, Mastercharge, was introduced by a single bank in 1973 (Roseman, ibid). While admitting that records are incomplete, Croft (1999, p. 8) says that the first 'full-fledged' adoption of ATM technology occurred in 1977. ${ }^{14}$ She indicates that other major banks followed suit in the next three to six years.

\section{Creation of the Canadian Payments Association}

The availability of new payment instruments, in particular inter-bank direct debits and credit transfers, as well as the growing competitive pressure exerted by NBFIs, led the Canadian Federal Government to broaden access to the payments system (Staff at the Bank of Canada and Department of Finance, 1997, p. 3). In 1980, it passed the Canadian Payments Association Act, which created the Canadian Payments Association ("CPA") and gave it responsibilities for clearing and settlement that had been held by the Canadian Bankers Association since 1900 (Quigley, 1996, pp. 43-45). Specifically, the Act gave the CPA two objectives: "The Association shall establish and operate a national clearings and settlements system, and shall plan the evolution of the national payments system." The CPA initially had a board of directors with 11 members; a chairman appointed by the central bank, the Bank of Canada, five directors are

\footnotetext{
14 ATMs are commonly known as automated banking machines (ABMs) in Canada,
} 
appointed by the chartered banks; two by trust and loan companies, two by credit union centrals and one by other members. Quigley argues that the CPA Act simply transferred the statutory that been held by the Canadian Bankers Association to the CPA, extended it to encompass a larger number of institutions and explicitly rejected the idea that competition should shape the evolution of the Canadian payments system.

In 1983, the Canadian Bankers Association transferred responsibility for the national settlement system to the CPA (Benson, 2003, p. 6). The following year, the CPA introduced the inter-bank funds transfer system, Automated Clearing Settlement System ("ACSS"), to facilitate clearing and settlement of many retail transactions (Staff at the Bank of Canada and Department of Finance, 1997, p. 4). ${ }^{15}$ This clearing system was composed of institutions that were either direct or indirect clearers: direct clearers had an account at the Bank of Canada that could be debited or credited for settlement; indirect clearers maintained an account with a direct clearer to be used for settlement (Dingle, 2003, pp. 14-15). As Dingle says, becoming a direct clearer meant being of a sufficient size:

Any direct clearer had to be a relatively significant institution; pursuant to the Clearing By-law, it had to account for at least one-half per cent of the national payments volume - the number of cheques and other items passing through the clearings.

\section{Interac debit cards}

In 1984, five institutions that issued Visa credit cards announced their intention to interconnect their ATM networks utilising the Visa Credit Card Authorisation Network (Competition Tribunal, 1996a, para. 19). The joint venture was named Interac and had the express purpose of sharing certain payment system services between members. In

\footnotetext{
15 Visa and MasterCard transactions are settled using Canada's wholesale interbank payment system, Large Value Transfer System (O’Connor, 2003, p. 26)
} 
1985, Bank of Montreal, a MasterCard issuer, responded to this announcement by saying that it, along with a number of other financial institutions, was developing an alternative shared ATM network, Circuit, (ibid, para. 21). However, development of Circuit stagnated soon after, when the five original Visa-issuing members of Interac invited the four largest MasterCard-issuing organisations, including Bank of Montreal, to participate in Interac (Anderson and Rivard, 1999, p. 402). Shared ATM services were established by Interac in 1986 and Interac's members decided to adopt the CPA's clearing and settlement system, ACSS, to complete transactions made using Interac (ibid, p. 405).

Interac adopted an organisational structure similar to that used by the CPA. The nine original organisations discussed above became Charter Members of Interac, establishing direct connections with each other to make use of the shared services (Interac Association, 2007, pp. 3). A tenth bank, the Laurentian Bank, was admitted as a charter member in May 1988 (Anderson and Rivard, 1999, p. 402). Other institutions were able to gain indirect access to Interac's network by using an account with a Charter Member and becoming a Sponsored Member.

Interac offered less than complete ATM services as its by-laws precluded the sharing of services such as balance inquiries, transfers and deposits (Competition Tribunal, 1996a, para. 26). Although new entrants might have exploited opportunities such as these to improve services, Interac faced only limited competition from new networks. In 1984/85, NBFIs introduced two ATM networks, Express and Access ATM in major Canadian cities with both networks obtaining commitments from retailers, network service suppliers and smaller financial institutions (ibid, para. 22; Anderson and Rivard, 1999, p. 402). However, Express failed in 1986 and Access ATM the following year 
partly because, according to the Competition Tribunal, neither was able to interconnect with Interac.

In 1989, Interac announced plans to develop a new shared service, the debit card POS payment system called Interac Direct Payment. An initial pilot of the service was run in 1990 followed by its nationwide introduction in 1994 (Competition Tribunal, 1996a, para. 31). All Charter Members of Interac were required to contribute equally to the costs of new shared services (ibid, para. 30). One Member, the Laurentian Bank of Canada, was unwilling to do so for the new shared service, resulting in the loss of its Charter Member status, although it retained direct connections with Interac's other Charter Members, meaning it did not have to become an indirect connector.

In 1988, American Express attempted to become a Sponsored Member of Interac, in order to provide its cardholders with access to Interac ATMs (Anderson and Rivard, 1999, p. 418). Anderson and Rivard comment that, “[a]t about the same time," Interac's Charter Members undertook a review of membership rules and, as a result, amended its by-laws in 1989, significantly increasing the cost of becoming a Sponsored Member and preventing the admission of new Chartered Members. In 1991, a number of Sponsored Members of Interac attempted to establish Sunrise, a network offering ATM and EFTPOS services (Competition Tribunal, 1996a, para. 32). However, the attempt was abandoned when, according to the Competition Tribunal, it became clear that Sunrise was ineligible for direct connection to Interac. Late in 1995, the credit union, Capital City Savings and Credit Union of Edmonton, introduced the MasterCard Maestro debit card (Johnston, 1995, December). However, the membership of Interac was shortly after expanded to include credit unions.

The expansion in membership was the result of a government inquiry that started in 1992, following a complaint from American Express regarding the structure of Interac 
(Anderson and Rivard, 1999, pp. 410, 418). Based on evidence from the inquiry, the responsible government official, the Director of Investigation and Research, concluded that "the Interac arrangement had inhibited the evolution towards a competitive shared ATM/POS markets in Canada and, if left unattended, it would continue to inhibit this process." Accordingly, an application was made to the federal, quasi-judicial Competition Tribunal for an appropriate order, known as a Consent Order. The Consent Order, approved by the Tribunal in June 1996, amended Interac's by-laws to increase its membership, ${ }^{16}$ implemented a new governance structure, required Interac to set prices only to recover costs- (that is, Interac would operate on a not-for-profit basis) and allowed merchants to impose a surcharge for Interac transactions (Bergevin, 2010, p. 5). Anderson and Rivard (1999, pp. 444-446) discuss the difficulty of finding an appropriate remedy based on competition, when relevant legislation placed many payment system decisions in the hands of the CPA. In particular, the Director elected not to challenge the use of the CPA ACSS system for clearing and settling Interac transactions, or to call for an end to Interac's prohibition on direct card issuance by nonfinancial institutions, as these were matters that the Canadian Government had required the CPA to decide.

In order to recover its costs, Interac was able to set switch and interchange fees, although it chose not to set an interchange fee, maintaining a small fixed switch fee paid by both the issuer and the acquirer for each transaction, with banks able to set fees for cardholders and merchants (Competition Tribunal, 1996a, p. 42). A Canadian newspaper report from 1997 shows that cardholders are generally charged small fixed fees of less than $\mathrm{C} \$ 0.50$ per transaction, although no transaction fees were charged for some accounts (Canadians love their debit cards, 1997, November 3). Based on data

\footnotetext{
16 The membership of Interac expanded from 27 companies in 1996 to 62 in 2010 (Bergevin, 2010, p.
} $5)$. 
from a 2006 national survey of Canadian merchants, Arango and Taylor (2008, p. 10) calculate the median MSF for Interac debit card transactions varying from $\mathrm{C} \$ 0.07$ for the lower quartile to $\mathrm{C} \$ 0.25$ for the upper quartile. ${ }^{17}$ Arango and Taylor also report (p. 8) that merchants are required to install terminals, although these may be rented as well as purchased. What little information I have found suggests the surcharging of debit card transactions that does occur is higher than these MSFs. Carrick (2003, May 29) cites a merchant debit card payment service provider controlling one third of debit card services in Canada as reporting that fewer than $1 \%$ of its clients surcharged Interac transactions. Carrick reports, however, that the surcharging that does occur ranges from approximately $\mathrm{C} \$ 0.25-0.45$, which appears excessive when compared to data on the size MSFs for Interac transactions provided by Arango and Taylor (C $\$ 0.07$ for the lower quartile to $\mathrm{C} \$ 0.25$ for the upper quartile).

\section{Other payment instruments}

Another new system created around this time, but one that involved less onerous government- or CPA-imposed regulations, was one created for a stored-value payment instrument, although it did not progress beyond the pilot stage. In 1997, 10 major Canadian financial institutions created Mondex Canada to develop the Mondex storedvalue card system (Craig and Blackwell, 1998, October 31). Mondex Canada launched an initial pilot in Guelph, Ontario before several of its backers pulled out of the project. It tried more pilots, but the system had been shelved by 2001 (Partridge, 2001, 10 May).

\subsubsection{A New Approach to the Regulation of Banks}

\section{The Canadian Payments Act 2001}

\footnotetext{
17 For credit cards, Arango and Taylor say merchants are charged a median MSF of 2 percent of transaction value for credit card transactions, which varied from a lower quartile of $1.75 \%$ to an upper quartile of $2.5 \%$.
} 
In 1992, a process of regularly reviewing financial legislation was made more formal when the Government incorporated sunset clauses into specific pieces of legislation requiring a review every five years (Daniel, 2003, pp. 5-6). The 1992 review resulted in legislation that continued to remove regulations that separated the activities of financial institutions. For example, it removed constraints on the operations of financial institutions and phased out the non-interest-bearing reserve requirements imposed on banks that did not affect other deposit-taking institutions. The 1997 review investigated the effects of changes made following the 1992 review and made only minor modifications (Daniel, 2003, p. 6). Separate from this review process, however, Canada introduced legislation modifying its prudential regulation and supervision in 1996, allowing life insurance companies to demutualise and allowing foreign banks to enter Canada as branches rather than as subsidiaries in 1999 (Daniel, 2003, pp. 6-7). However, in spite of the changes, the intrusive nature of ownership rules, including authorities' rejection of bank merger plans, has contributed to concerns about the industry. In his review of financial reform in Canada, Siklos (2003, p. 60) comments that "... the view that Canadian banks are not sufficiently competitive partly stems from the rigid ownership rules that prevent the flexibility necessary to react rapidly to changing market opportunities."

Relating to payment systems, the Federal Government announced another review in June 1996 to be conducted by the Ministry of Finance with assistance from a Payments System Advisory Committee (Department of Finance, 1998, p. 2). Following the review, the Canadian Government passed the Canadian Payments Act 2001 (Dingle, 2003, pp. 49-52). The Act modified the Canadian Payments Association Act 1980, adding to the CPA's objectives the goal of promoting "the efficiency, safety and soundness of its clearing and settlement systems and take into account the interests of users", expanding its membership to include life insurance companies, securities dealers 
and money market mutual funds and introducing the ability for the Minister of Finance to review the CPA's by-laws.

\subsubsection{Payment System Development Following the Reforms}

\section{Issues with new payments instruments}

At the end of 2003, Interac adopted an email-based payment system (Banks adopt INTERAC branding for Email Money Transfer service, 2003, 19 December). This service allowed the customers of banks to use bank websites to simply send payments to email addresses to be deposited in another Canadian bank account. Interac Online, a system allowing debit card payments over the internet, was launched in mid-2005 (Bank groups back new Canadian online debit choice, 2005, June 14). However, in spite of the legislative changes and the new instruments, problems of access still existed for CPA payment systems. While deliberating over the Interac Consent Order in 1996, the Competition Tribunal considered a concern raised by Telpay, a company providing bill payment services over the telephone, that the Consent Order assumed "any new Interac service would be based on plastic card and terminal-based technology" (Competition Tribunal, 1996b, pp. 44-45). Telpay, however, wanted to use the Interac network to allow its customers to complete transactions over the telephone. The Competition Tribunal held that Telpay's complaint was beyond the scope of the issues it was considering (1996b, pp. 44-45). In the middle of 2003, the CPA decided to implement a ban of certain telephone-based payments called tele-cheques, which prevented CPA members from processing such items during clearing (Canadian Payments Association, 2003).

In early 2007, a number of retail payment system issues were discussed by the House of Commons Standing Committee on Finance. The Standing Committee heard evidence regarding the length of time it took to complete electronic bill payments in Canada 
(Standing Committee on Finance, 2007, March 22). The CPA gathered information from member financial institutions and other stake holders and, in February 2008, established Bill Payment Task Force to recommend ways in which bill payments in Canada might be improved "in areas consistent with the CPA's mandate." (Canadian Payments Association, 2008, p. 7; Canadian Payments Association, 2009, p. 23). The CPA also prepared an Issues Paper (Canadian Payments Association, 2008) reviewing interbank operations for bill payments in Canada and other countries. The Paper considers in detail the CPA's existing framework for bill payments, highlighting (p. 6) anecdotal evidence that indicated up to $80 \%$ of billers had elected to operate outside that framework. Reasons for this include difficulties applying the framework to a biller's billing process. The paper indicates (p. 8) that some larger billers went as far as establishing accounts at numerous banks to increase the number of customers paying bills with an "on-us" transaction rather than with an interbank transfer. During 2009, the Bill Payment Task Force developed a draft Policy Framework for all bill payments to be cleared and settled using CPA's ACSS interbank payment system (Canadian Payments Association, 2009, p. 23).

Further evidence on bill payments was given to the Standing Committee by representatives of Usemybank, a third party provider (not a financial institution) of bill payment services (Standing Committee on Finance, 2007, April 19). Usemybank complained that, in 2003, two of Canada's banks had closed the biller accounts used for settlement with those two institutions by Usemybank's own financial institution. ${ }^{18}$ Another Canadian bank did the same in 2005, shortly before it launched Interac Online. Also in 2005, the CPA implemented a rule that required all bill payments to be initiated

18 Vexler (2004, October 31) provides a description of the nature of Usemybank's service and biller accounts. 
using the CPA member's own website, precluding the use of a third party's website (Canadian Payments Association, 2005, February 3).

\subsubsection{Interventions in Retail Payment Systems}

\section{Interac, Visa and MasterCard}

Another five-yearly review of Canada's financial legislation began with consultation in 2005, followed by a Discussion Paper released during 2006 and the Government tabling new legislation in November of that year (Department of Finance, 2006, p. 5;

Department of Finance, 2006, November 27). The review was notable for the development of new retail payment systems because it contained no proposals for the direct regulation of payment cards, despite expectations that it would. ${ }^{19}$ In fact, a major control on payment cards was removed during 2008, when Canada's Competition Commissioner formally announced that the Competition Bureau would no longer oppose duality of membership in credit card networks that operated in Canada, following changes in the ownership structure of Visa and MasterCard (Redican, 2008, November 24). However, regulation of credit cards re-appeared on the political agenda late in 2010 when the Competition Bureau announced it had made an application to the Competition Tribunal for the Tribunal "to strike down restrictive and anti-competitive rules that Visa and MasterCard impose on merchants who accept their credit cards", referring to both the networks' use of the No-Surcharge Rule and the Honour-All-Cards Rule (Competition Bureau, 2010, December 15).

Development of Interac continued with the network preparing to face increasing competition. ${ }^{20}$ In 2007, Interac began discussions with Canada's Competition Bureau in

\footnotetext{
19 For discussion of such expectations, see Canada rewrites its financial services regulations (2005, August 30).

20 As an example of the development, Interac supported the roll-out of EMV technology to Canada, leaving individual roll-out decisions to each bank, but notifying customers that it would no longer
} 
an attempt to modify the 1996 Consent Order described above, to allow it to become a for-profit company in order to cope with an increasingly competitive and innovative environment (Standing Senate Committee on Banking, Trade and Commerce, 2009, p. 25). In February 2010, however, the Competition Bureau turned Interac's request down (Lowe, 2010, February 26). During 2008, MasterCard and Visa made changes to interchange fee schedules for credit card transactions and MasterCard re-launched its Maestro debit card in December of that year. ${ }^{21}$ MasterCard publishing details showing Maestro operated with no interchange fee and a fixed switch fee paid by both the issuer and acquirer of C\$0.005 per transaction (Arnfield, 2009, September 23). However, Perkins (2010, January 18) reports that at least one major bank had delayed introducing the Visa Debit card because of ongoing uncertainty regarding regulation of the debit and credit card industry in Canada.

Those concerns about uncertainty followed the release in June 2009 of Senate Committee report covering the credit and debit card systems in Canada. The report recommended that a code of conduct for debit and credit cards be established, merchants be permitted to bargain collectively regarding terms and fees, merchants be allowed to surcharge for credit card use, debit card fees be charged on a flat fee, rather than proportional, basis and that the interchange fee for all debit card transactions be set at zero for three years. In 2009, Canada's Minster of Finance released a draft code of conduct, which included proposals that merchants be allowed to discount for cheaper payment methods (although not be allowed surcharge for more expensive ones), that cards not give access to debit and credit card functions and that, when a card gives

accept magnetic strip transactions in ATMs from the end of 2012 and in POS transactions from the end of 2015 (Interac Association, 2010).

21 While the report comments that this was MasterCard's "first" transaction using its Maestro brand in Canada, that claim appears to ignore the launch, discussed earlier, of a MasterCard Maestro debit card by a credit union in December 1995. 
access to multiple networks, ${ }^{22}$ merchants be given control over which network is used for payment (Department of Finance, 2009, November 19). In 2010, the code was "voluntarily" adopted, although accompanying press release made it clear that the credit and debit card industry must adopt it or face a legally enforceable code under the Payment Card Networks Act (Archer, 2010, June 11). Later in 2010, the Canadian Imperial Bank of Commerce introduced a Visa-debit card, called the Advantage Card (Visa-branded debit cards swiping into Canada, 2010, October 19). However, the article says that the card would operate by processing POS transactions over the Interac debit card network, meaning merchants would not incur higher MSFs using the Visa Debit for POS transactions.

Development of stored-value card systems continues in Canada with Interac announcing that it would roll-out contactless terminals in early 2011 as part of its expansion for EMV (Hernandez, 2010, June 17). Hernandez reports that the move came as several Canadian banks started issuing Visa payWave technology, which would eventually be compatible with the Interac contactless terminals.

\subsubsection{Data Showing Payment Instrument Adoption in Canada}

My key data source showing the adoption of debit and credit cards in Canada is transaction and population data available from the Redbook publication, CPSS (2009), which provides estimates of issued transactions for the years 2004 to 2008 . For the years 2000 to 2003, I use data from an earlier Redbook, CPSS (2006). Both documents clarify that all figures are estimates. While I did not find any corroborating data for Canada, I did find a reference to this source of transaction data made by an employee of

22 This might occur when, for example, a card gives access to both the Interac network and the Visa or MasterCard debit card network. 
the Bank of Canada (Taylor, 2006, p. 27), giving me greater confidence in the accuracy of the figures, at least relative to other data sources for Canada.

\subsubsection{Bibliography for Summaries of Canada}

Anderson, R. and Rivard, B. (1999). Antitrust policy towards EFT networks: The Canadian experience in the Interac case, Antitrust law journal, 67(2), 389-452

Arango, C. and Taylor, V. (2008). Merchant acceptance, costs, and perceptions of retail payments: a Canadian survey. Bank of Canada discussion paper, 2008-12

Archer, J. (2010, June 11). Voluntary code of conduct for the credit and debit card industry in Canada. Mondaq Business Briefing

Arnfield, R. (2009, September 23). A debit shakeup In Canada. Cards \& Payments, Retrieved on July 2, 2010 from http://www.paymentssource.com/news/debit-shakeupcanada-2700661-1.html?zkPrintable=1\&nopagination=1

Bank groups back new Canadian online debit choice. (2005, June 14). Electronic Payments Week, 2(23)

Banks adopt INTERAC branding for Email Money Transfer service. (2003, 19 December). Canada NewsWire

Benson, J. (2003, November 25). Evolution of the Canadian payments system and the issue of systemic risk, Econ*4760, University of Guelph, Department of Economics

Bergevin, P. (2010, February). Change is in the cards: competition in the Canadian debit card market, C.D. Howe Institute backgrounder No. 125, Retrieved from http://www.cdhowe.org/pdf/backgrounder_125.pdf

Campbell, M. (1989, March 25). The credit card comes of age, The globe and mail

Canada rewrites its financial services regulations. (2005, August 30). Electronic payments week, 2(34)

Canadian Payments Association. (2003, June 1). Prohibition of Tele-cheques in the clearing \& settlement system: Policy statement, Issued by the CPA Board of Directors, Retrieved from http://www.cdnpay.ca/news/tele.asp

Canadian Payments Association. (2005, February 3). Rule E2 - Exchange for the purpose of clearing and settlement of electronic on-line payment items, Retrieved from http://www.cdnpay.ca/rules/pdfs_rules/rule_e2.pdf

Canadian Payments Association. (2008, February). Issues paper: Review of bill payments in Canada, CPA policy and research division, Retrieved from http://www.cdnpay.ca/publications/pdfs_publications/bill_payments_issues_paper_200 $\underline{8 . p d f}$ 
Canadian Payments Association. (2008). Annual review, Ontario: Canadian Payments Association, Retrieved from http://www.cdnpay.ca/publications/pdfs_publications/annual_review_2008.pdf

Canadian Payments Association. (2009). Annual review, Ontario: Canadian Payments Association, Retrieved from http://www.cdnpay.ca/publications/pdfs_publications/annual_review_2009.pdf

Canadian Payments Association. (2010). CPA member list, Retrieved on February 24, 2010 from http://www.cdnpay.ca/membership/member.asp

Canadians love their debit cards. (1997, November 3). Winnipeg free press, Finance and Business

Carrick, R. (2003, May 29). Costly surcharges looming for debit payments. The globe and mail

Committee on Payment and Settlement Systems [CPSS]. (2006). Statistics on Payment and Settlement Systems in Selected Countries. Prepared by the Committee on Payment and Settlement Systems of the Group of Ten Countries, Publications No. 74, retrieved from http://www.bis.org/publ/cpss74.htm

Committee on Payment and Settlement Systems [CPSS]. (2009). Statistics on Payment and Settlement Systems in Selected Countries. Prepared by the Committee on Payment and Settlement Systems of the Group of Ten Countries, Publications No. 88, retrieved from http://www.bis.org/publ/cpss88.htm

Competition Bureau. (2010, December 15). Competition Bureau challenges Visa and MasterCard's anti-competitive rules, Retrieved from http://www.competitionbureau.gc.ca/eic/site/cb-bc.nsf/eng/03325.htmlCompetition Tribunal. (1996a). Statement of Grounds and Material Facts

Competition Tribunal. (1996a). Statement of Grounds and Material Facts

Competition Tribunal. (1996b). Reasons for Consent Order

Craig, S. and Blackwell, R. (1998, October 31). Mondex pulls plug on Guelph pilot project. The Globe \& Mail

Croft, E. W. (1999). Transaction fees in banking machine networks: A spatial and empirical analysis. Doctoral dissertation, University of British Columbia, Retrieved from http://circle.ubc.ca/handle/2429/9850

Daniel, F. (2003). Recent Changes to Canada's Financial Sector Legislation, Bank of Canada review, Winter 2002-2003, 3-16

Department of Finance. (1998). Payments system review discussion paper, retrieved on February 23, 2010 from http://www.fin.gc.ca

Department of Finance. (2006). 2006 financial institutions legislation review: Proposals for an effective and efficient financial services framework. Ottawa: Department of Finance, Retrieved from http://www.fin.gc.ca/activty/pubs/White06e.pdf 
Department of Finance. (2006, November 27). Canada's new government tables legislation to strengthen Canada's financial system, News Release 2006-074, Retrieved from http://www.fin.gc.ca/n06/06-074-eng.asp

Department of Finance. (2009, November 19). Government of Canada introduces proposed code of conduct for Canadian credit and debit card industry, News Release 2009-109, Retrieved from http://www.fin.gc.ca/n08/09-109-eng.asp

Dingle, J. (2003) Planning an evolution: the story of the Canadian Payments Association, 1980-2002, a joint publication of the Bank of Canada and the Canadian Payments Association, May

Hernandez, W. (2010, June 17). Canada's Interac adding contactless feature to EMV cards. ATM \& debit news

Interac Association. (2007, September). Interac Association: A backgrounder, Retrieved from http://www.interac.ca/pdf/backgrounder_en.pdf

Interac Association. (2010). Chip, Retrieved on 2010, May 25 from http://www.interac.ca/merchants/chip.php

Johnston, B. (1995, December). Regina company unveils worldwide debit card. Regina Leader Post, Retrieved from http://www.cuets.ca/news/1995/releas6.htm

Lowe, F. (2010, February 26). Canadian Bureau rejects Interac's request for for-profit status, but leaves door open. Cardline, 10(9)

O'Connor, S. (2003). Developments, issues, and initiatives in retail payments, Bank of Canada review, pp. 23-37

Partridge, J. (2001, 10 May). Oasis enters 'smart' card alliance: multifunction payment system years away. The globe and mail

Perkins, T. (2010, January 18). Card payment players clash over code; Ottawa assessing industry submissions over plan to adopt rules for the credit, debit sector. The globe and mail

Quigley, N. (1996). Public policy in the Canadian payments system: risk, regulation, and competition. In Mintz, J. and Pesando, J. (eds.) Putting Consumers First: Reforming the Canadian Financial Services Industry, Toronto: C D Howe Institute, pp. 41-72

Roseman, E. (2008, August 17). The power and peril of credit cards. The Toronto star

Redican, S. (2008, November 24). Smooth sailing ahead for credit card duality in Canada. Mondaq business briefing

Siklos, P. L. (2003). Financial reform in Canada: past, present and future. In Hall, M. J.B. (Ed.), The international handbook on financial reform, pp. 51-72, Cheltenham: Edward Elgar Publishing Limited. 
Staff at the Bank of Canada and Department of Finance. (1997). The payments system in Canada: An overview of concepts and structures, discussion paper 1 for the Payments System Advisory Committee, Retrieved from http://boclab.com/pdf/psac1.pdf

Standing Committee on Finance. (2007, March 22). Edited Evidence, House of Commons, Retrieved from

http://www2.parl.gc.ca/HousePublications/Publication.aspx? DocId=2793160\&Languag $\underline{\mathrm{e}=\mathrm{E} \& \text { Mode }=1 \& \operatorname{Parl}=39 \& \mathrm{Ses}=1}$

Standing Committee on Finance. (2007, April 19). Edited Evidence, House of Commons, Retrieved from

http://www2.parl.gc.ca/HousePublications/Publication.aspx?DocId=2852655\&Languag $\underline{\mathrm{e}=\mathrm{E} \& \text { Mode }=1 \& \operatorname{Parl}=39 \& \mathrm{Ses}=1}$

Standing Senate Committee on Banking, Trade and Commerce. (2009, June).

Transparency, Balance and Choice: Canada's Credit Card and Debit Card Systems, House of Commons , Retrieved from

http://www.parl.gc.ca/40/2/parlbus/commbus/senate/com-e/bank-e/rep-e/rep04Jun09e.pdf

Taylor, V. (2006). Trends in retail payments and insights from public survey results. Bank of Canada review, Spring, Retrieved from http://www.bankofcanada.ca/en/review/spring06/taylor.pdf

Vexler, A. (2004, October 31). UseMyBank: Finally, an internet debit payment solution. The frontier times: Canada's payments journal, Retrieved on March 3, 2011 from http://canadianpayments.blogspot.com/2009/04/usemybank-finally-internet-debit.html

Visa-branded debit cards swiping into Canada. (2010, October 19). The Hamilton Spectator

Weiner, S. and Wright, J. (2005). Interchange fees in various countries: Developments and determinants. Review of network economics, 4(4) 


\subsection{European Union}

\subsubsection{Affect on Retail Payment System Development in European Countries of My Sample}

Legislation made in three of the countries in my sample is heavily influenced by the actions of the European Union. The Union may issue "Regulations", which immediately become enforceable as law in all member states simultaneously, and "Directives", which give legislative frameworks that must be put in place by member states. Although not a member of the European Union, Norway's membership of the European Economic Area means it is required to adopt the legislative initiatives with respect to forming a single European market and be a 'virtual member' of the Union (Emerson, Vahl and Woolcock, 2002).

In 2002, the European Payments Council was set up by the banking industry as part of a self-regulatory initiative to develop a common infrastructure and standards. In 2008, the Council announced initiatives to create a Single Euro Payments Area ("SEPA") by eliminating differences in national standards for payments. Processes associated with SEPA continue with rulebooks for SEPA payments by credit transfer and direct debit being published in 2007 (Skinner, 2008, p. XXVI).

European directives with an influence on retail payment systems include the Payment Services Directive (2007/64/EC), adopted in 2007, and the Consumer Credit Directive (2008/48/EC), adopted in 2008. The Payment Services Directive mentioned an Electronic Money Institution, but created another category of financial institution, a Payment Institution, also giving it a European Passport or access to markets across the European Union. Such directives are commonly prescriptive; for example, the Consumer Credit Directive places significant restrictions on the use of information used for credit approvals for individuals. In addition to these directives, the European 
Commission has conducted a number of investigations of interchange fees and network rules applying largely to cross-border transactions made with Visa and MasterCard debit and credit cards. ${ }^{23}$ These investigations directly influence only the fraction of debit and credit card transactions that are cross-border - most transactions are completed domestically and do not require issuing or acquiring services from another country. ${ }^{24}$ That said, the investigations may have affects beyond just cross-border transactions. For example, Retail Banking Research Ltd (2005, p. 46) reports that MasterCard Europe has removed its No-Surcharge Rule, allowing merchants to surcharge credit transactions made with its debit and credit cards in Europe. I have not, however, found sufficient evidence to allow me to explore the role of the European Commission in such decisions.

Because they directly affect only a small proportion of transactions and, even then, affect debit and credit cards, which are payment instruments that have already experienced a significant amount of development, I argue that much of the European Commission's operations are beyond the scope of this thesis. One group of the decisions appear, however, to have had a significant influence on development, the Commission;'s directives relating to electronic money.

\subsubsection{The European Union and the Development of Electronic Money}

Athanassiou and Mas-Guix (2008) describe in detail the development of two European Directives in relation to the issuance of electronic money. Although the Directives were issued by the European Commission, they describe (pp. 13-16) the European Central

\footnotetext{
23 European Commission Memos from 2007 and 2009 dealing with MasterCard and Visa interchange fees say that relevant fees applied not only to cross-border transactions, but to domestic transactions in a number of European Union members, none of which I study in this thesis (European Commission, 2007, December 19; European Commission, 2009, April 6),

24 For example, MasterCard calculated that a cross-border multilateral interchange fee applied in just $5 \%$ question of total MasterCard transactions in the European Economic Area (Repa, Malczewska, Teixeira and Martinez Rivero, 2008).
} 
Bank's high level of interest in e-money development, particularly its concerns that consumers and merchants were adequately protected. Of the two Directives, the first, Directive 2000/28/EC, amended an earlier banking Directive to include electronic money issuers within the definition of credit institution, thereby giving issuers of electronic money access to a "European passport" to operate across the European Union, and the second, Directive 2000/46/EC, which became known as the Electronic Money Directive, defined an e-money issuer as a special type of credit institution, subject to similar prudential supervision rules to those that applied to banks.

Athanassiou and Mas-Guix outline the significant uncertainty caused by the Directives' shortcomings. In particular, they argue the Directives did not appropriately address the definition of electronic money ${ }^{25}$, failed to consider mechanisms for clearing and settling electronic money transactions and placed potentially inappropriate restrictions on the operations of electronic money issuers ${ }^{26}$.

In spite of the significance of these issues, however, Athanassiou and Mas-Guix (2008, pp. 16-17) appear to regard it reasonable to find a solution to them by making small adjustments to the regulatory framework for electronic money. Indeed, the European Commission adopted an updated Directive applying to electronic money (2009/110/EC), which, while it was intended to liberalise the market by lowering barriers to entry (Financial Services Authority, 2010), maintained a prescriptive approach to the operations of issuers of electronic money.

25 As I've discussed, I also find the phrase electronic money unclear and prefer to use, stored value card, to refer to the card-based prepaid retail payment instrument. The term, electronic money might also refer to computer-based retail payment systems that use the internet. However, I focus on stored-value instruments because the Commission's affect of the development of such instruments is more obvious.

26 For example, in order for a company to be licensed as an electronic money institution, the Electronic Money Directive required that it meet initial capital and ongoing own funds thresholds and that there be restrictions on their investment in other businesses and the scope of their operations. 


\subsubsection{Bibliography for Summary of the European Union}

Athanassiou, P. and Mas-Guix, N. (2008). Electronic money institutions: Current trends, regulatory issues and future prospects. European Central Bank legal working paper series, No 7, Retrieved from http://www.ecb.int/pub/pdf/scplps/ecblwp7.pdf

Emerson, M,. Vahl, M. and Woolcock, S. (2002). Navigating the stars: Norway, the European Economic Area and the European Union, Brussels: Centre for European Policy Studies

European Commission. (2007, December 19). Antitrust: Commission prohibits MasterCard's intra-EEA Multilateral Interchange Fees - frequently asked questions, MEMO/07/590, Brussells, Retrieved from http://europa.eu/rapid/pressReleasesAction.do?reference=MEMO/07/590\&format=HT $\underline{\text { ML\&aged }=0 \& \text { language }=\text { EN\&guiLanguage }=\mathrm{fr}}$

European Commission. (2009, April 6). Antitrust: Commission sends Statement of Objections to Visa, Brussells, MEMO/09/151, Retrieved from http://europa.eu/rapid/pressReleasesAction.do?reference=MEMO/09/151

Financial Services Authority. (2010). E-Money Directive. Retrieved from http://www.fsa.gov.uk/pages/About/What/International/pdf/EMD.pdf

Repa, L., Malczewska, A., Teixeira, A. C. and Martinez Rivero, E. (2008). Commission prohibits MasterCard's multilateral interchange fees for cross-border card payments in the EEA. Competition policy newsletter, No 1, Retrieved from http://ec.europa.eu/competition/publications/cpn/2008_1_1.pdf

Skinner, C. (ed.) (2008, May). The future of finance after SEPA, Chichester: John Wiley \& Sons 


\subsection{Germany}

\subsubsection{Retail Payment Systems and Government Controls of Banking}

\section{The German banking system}

Brunner, Decressin, Hardy and Kudela (2004) provide details of Germany's banking system, which consists of three pillars, the public banks, the cooperative banks and the commercial banks. The public banks can be further broken into two tiers, Sparkassen and Landesbanken. The Sparkassen or savings banks, the first of which originated in Hamburg in 1778, are mostly owned by local government. Landesbanken, which date back to the early twentieth century, function as central banks for the Sparkassen and are owned by municipalities and associations of Sparkassen. The cooperative banking pillar (Volksbanken, Raiffeisenbanken and Spar- und Dahrlehenskassen) dates back to the nineteenth century when banks were founded to help craftsmen, workers and farmers. Cooperative banks are owned by their members, who are also their depositors. Finally, there are the commercial banks, which are dominated by the "big four", Deutsche Bank, Hypovereinsbank, Dresdner Bank and Commerzbank, who account for roughly two-thirds of commercial bank business in Germany. Table 4.1 provides details on the size of the three pillars. 
Table 4.1. Summary of German Financial System, 2001

\begin{tabular}{lrr}
\hline Pillar & $\begin{array}{c}\text { Number of } \\
\text { Institutions }\end{array}$ & $\begin{array}{c}\text { Share of } \\
\text { Business Volume } \\
(\boldsymbol{\%})\end{array}$ \\
\hline $\begin{array}{l}\text { Public Sector Banks: } \\
\quad \text { Landesbanken }{ }^{(1)}\end{array}$ & 13 & 20.2 \\
$\quad$ Sparkassen & 534 & 15.7 \\
Cooperative Banks & 1623 & 12.2 \\
Commercial Banks & 304 & 43.1 \\
Other & & \\
Total & 235 & 8.8 \\
\hline
\end{tabular}

Source: Brunner et al (2004, pp. 2-3)

(1) Includes DGZ/DEKA Bank as a Landesbank because it performs similar role as other Landesbanken, but is not associated with a specific Land or region.

(2) Includes public sector mortgage banks

Brunner et al (2004) comment that profit is unlikely to be the key objective for two of the major pillars, the public sector banks and the cooperative banks. Although some of the funding of Landesbanken and Sparkassen comes from retained earnings, therefore giving them some desire to maximise profits, they have a mandate to foster economic development in their regions and are expected to subsidise local public goods. Because of their cooperative structure, the ownership of the cooperative pillar is held widely, reducing incentives to monitor and discipline the organisations' management. ${ }^{27}$ Additionally, the incentive to monitor the operations of banks is reduced by a number of institution and deposit protection schemes, although these are starting to be phased out (Brunner et al, ibid, pp. 3-5, 24-25). Reszat (2003, p. 88) reports that the German financial system "has long been notorious for its financial market backwardness." $\mathrm{He}$ attributes this to outdated structures, high costs and a high degree of bureaucracy that 
have deterred investment. Indeed, Brunner et al (2004) find bank profitability lower in Germany, compared to countries with similar banking systems.

In 1908, the first German Giro Association was established and the system proved popular. Other associations followed with a national giro institution being founded in 1918 as a central point for all the associations (Pohl and Freitag, 1994, p.469; Vittas, 1995, p. 9). Under the German Banking Act of 1961 the "provision of cashless payment and clearing operations (giro business)" is a banking activity, meaning that NBFIs are not allowed to handle cashless transactions (CPSS, 2003, p. 151). To be a bank and provide such services, a licence as a credit institution or a financial services institution is required from the German Federal Financial Supervisory Authority (Bundesanstalt für Finanzdienstleistungsaufsicht). The role of Germany's central bank, the Deutsche Bundesbank, is set out in the Bundesbank Act of 1957 and requires the Bundesbank to "arrange for the execution of domestic and international payments and contribute to the stability of payment and clearing systems" (European Central Bank, 2007, p. 103). A paper by the European Central Bank (2007) discusses the Bundesbank's interpretation of this role in regard to retail payment systems (p. 104):

The Bundesbank is actively involved in shaping developments in cashless payments. By means of a cooperative approach, it attempts to coordinate the interests and decisions of the parties involved in cashless payments and - if necessary - to facilitate decision-making, as well as fostering developments with regard to increased efficiency and security of payments.

However, the same paper goes on to say (p. 105) that "Germany took a conscious decision to avoid going down the route of a sovereign regulation by parliament or the central bank." It describes the Bundesbank's preference for multilateral agreements reached "by common accord by all of the central associations of the banking industry." The Bundesbank did, however, have some involvement with retail payment system development. In the early 1970s, it developed the Retail Payment System, which is 
used for the overnight processing of interbank transfers involving giros, cheques and direct debits complementing the giro networks of the banking system (Deutsche Bundesbank, n.d.; European Central Bank, 2007, p. 124).

In 1953, the Zentraler Kreditausschuss (“ZKA") ${ }^{28}$ was established; it consists of representatives of each of the central associations of the three groups (European Central Bank, 2007, p. 105). The statutes of the central associations are formulated in such a way that the associations can bind their member institutions (ibid, p. 105). As part of its interest in payment systems, the Bundesbank chairs the ZKA's Working Party on Automation, which was established in 1959 to discuss general aspects of payment automation. In 1963, following its creation, the German banking industry introduced the direct debit, which allows the payee, rather than the payer, to initiate payment, although the payer may have preauthorised payment (CPSS, 2003, p. 156).

\section{New payment instruments}

In 1968, one commercial bank, Deutsche Bank, introduced eurocheque, a cheque guarantee card that could be used in many places in Europe (Waiting for the plastic revolution, 1997, November 28). Debit card and ATM functionality were eventually incorporated alongside its cheque guarantee function. ${ }^{29}$ In 1977, Deutsche Bank led a consortium of European banks to acquire the travel and entertainment card, Eurocard, which already had an international alliance with the American credit card scheme, MasterCard. In 1982, the German banks pooled their credit card operations into a jointly-owned organisation, Gesellschaft fur Zahlungssysteme (“GZS”), which undertook all of Germany's Eurocard issuing and acquiring activities (ibid).

28 The ZKA is also known by its English translation, the Central Credit Committee or CCC. I refer to it by its German name in this thesis.

29 These other functions led to a decline in the use of the cheque guarantee function, which was withdrawn in 2001 (Deutsche Bundesbank, 2009, p. 4). 


\subsubsection{A New Approach to the Regulation of Banks}

Germany began a process of deregulation well in advance of what was required by its membership of the European Union (Buch and Golder, 2001). According to Buch and Golder (p. 348), foreign financial institutions had, "at least in principle," the ability to enter the German banking industry from 1976. In 1981, remaining capital controls and interest rate regulations were fully abolished. Significant controls remain, however. For example, an organisation that wishes to acquire bank-controlled debit card transactions has to be authorised and certified by the ZKA, a process that can take 9 to 12 months (Retail Banking Research Ltd, 2005b, September, p. 47). Also, legislation around the pillar of public banks hinders the efforts of members to restructure to improve profitability (Brunner et al, 2004, pp. 26-27). Indeed, concerns about the profitability of German banks have increased. Brunner et al find that profitability dropped significantly in the five years to 2001, which they attribute to non-interest revenue opportunities not being sought to compensate for interest rate margins declining because of increased competition.

Laws developed by the European Union also had a major impact on German financial regulation. Germany had fully implemented the European Union's Second Banking Directive, which harmonised financial regulation across member-states, by 1992. It also adopted the euro as a unit of account in 1999 before converting to using it as the only legal payment medium of exchange in 2002 (CPSS, 2003, p. 155). In 2003, German retail payment systems were connected to a new clearing procedure for EU cross-border credit transfers, called STEP2, allowing qualified credit transfers to the whole European Economic Area (European Central Bank, 2007, p. 101).

\subsubsection{Payment System Development Following the Reforms}

\section{Competition involving credit cards}


GZS's position as the monopoly provider of Eurocard services was tested by foreign banks, including Bank of America, which first issued Visa cards in 1981, although the number of banks issuing Visa cards remained small until the 1990s (Waiting for the plastic revolution, 1997, November 28). In the late 1980s and early 1990s, German merchants demonstrated a willingness to organise their own payment cards; a number of German retailers introduced the credit card, Deutsche Kreditkarte, in 1987 (Plastic explosives, 1987, July 4); and a major retail chain, Metro, introduced the YESS card, a delayed debit/credit store card, in 1992 (Worthington, 1994, pp. 34-35). The dismantling of GZS's monopoly on Eurocard services began in 1989 when some member banks began issuing their own brand of Eurocards, rather than using only the GZS to issue cards (Waiting for the plastic revolution, 1997, November 28). In 1996, GZS became a dual processor of Eurocard and Visa transactions and, the following year, was split into two entities: one to process Eurocard and Visa transactions under the GZS name; the other, EuroKartensysteme, to administer the Eurocard licences. In 1999, EuroKartensysteme gave up its monopoly on the acquiring of Eurocard transactions when it gave the two main Visa acquirers licences to also acquire Eurocard transactions (Welch, 2001, December 28). In 2002, Eurocard was merged with MasterCard in 2002 (Breitkopf, 2002, June 10).

In spite of these developments, however, credit cards have not seen significant use as a payment instrument. Several reasons appear to lie behind this. Firstly, consumer protection legislation on discounts and gifts, described as “draconian" by one media source, discouraged the use of loyalty credit card networks (Overdrafts and debit dominate over credit, 2004, December 20). The laws were repealed late in 2001 and industry sources expected this to cause a sharp increase in card payments (EHI Retail Institute, 2009, p. 31). Aside from a brief flurry of activity, however, this increase failed to materialise. Perhaps more important for explaining the country's low number 
of credit card transactions, however, is the use in Germany of bank account overdrafts as a source of consumer credit. This means that credit cards are used as delayed debit cards with only some banks experiencing success with offering revolving credit through credit cards (Overdrafts and debit dominate over credit, ibid). Bank account overdrafts in Germany are able to be accessed by another type of payment instrument, the debit card.

\section{German development of debit cards}

Beginning in 1983, the ZKA ran a number of tests of a debit card system, Electronic Cash, promoting its credit card company, GZS, to provide acquiring services to merchants (PoS in Germany, 1984; Chemnitz University of Technology, ${ }^{30} 2008$, June 22). ${ }^{31}$ The 1984 magazine article hints, however, that the distribution of costs between banks and retailers was an issue even at that early stage, but that the banking industry was pressing ahead with debit card development to forestall similar development by credit card schemes or by retailers. The article also shows that the industry was keen to avoid inter-network competition even amongst banks, when it quotes a representative of GZS saying that the aim in Germany is to "find a national solution and to allow no separate regional solutions which cannot be integrated into a general system at a later date." Nevertheless, development proceeded slowly and it was not until 1990 that the banks reached an agreement to create the online system, which charged merchants a proportional MSF of 0.3\%. (Howells and Hine, 1993, p. 52; CPSS, 2003, p. 157). The intervention of the Bundeskartellamt, the Federal Cartel Office, meant an open system was adopted that allowed merchants to obtain terminals and use the services of companies other than GZS. This led to the creation of the Netzbetreiber, a payment network operator, from which merchants could obtain terminals and Electronic Cash

\footnotetext{
30 Translation from German to English provided by Sabrina Pick (2010, October 14).

31 As I discuss below, Electronic Cash became known as Girocard in 2007.
} 
network services (A rough ride for European EFTPOS, 1990, April 12). This created a structure to a payment network that the European Commission, 2006, p. 19) report was unique to Germany amongst European countries. It is unique because the Netzbetreiber are the organisations that, effectively, collect MSFs and pass them to the appropriate issuing bank. The fee does not pass through an acquiring bank and therefore is not an interchange fee. In 2006, there were 24 Netzbetreiber, which are broadly independent of the banks (OCED, 2007, p. 156). In spite of the creation of the Netzbetreiber, merchants were not supportive of the new system, given the delays in its implementation and its charges to merchants, which came when they had not been charged for the Eurocheque system (Waiting for the plastic revolution, 1997, November 28).

At the same time Electronic Cash was being introduced, one department store, Peek and Cloppenburg, successfully introduced a debit card payment instrument, called Elektronisches Lastschrift Verfahren (“ELV”), using one major German bank, Deutsche Bank, to provide clearing functions for it (Howells and Hine, 1993, p. 52). ELV used a customer's Electronic Cash card to generate a direct debit, which the customer would authorise with his/her signature. Deutsche Bundesbank (2009, p. 5) argues that the ELV system proved popular because German merchants do not pay additional fees for using it. In fact, the CPSS (2003, p. 158) reports it was the most popular card-based payment instrument in Germany at that time. That was in spite of the ELV card involving higher amounts of risk for merchants, compared to other payment instruments, because it does not operate with a guarantee that a merchant will receive payment. The merchant bears the risk when a card is used fraudulently or the customer has insufficient funds in their account for the purchase, a risk that can be reduced by the retailer taking out insurance against such losses and consulting blacklists of stolen cards 
(Deutsche Bundesbank, 2009, p. 5). ${ }^{32}$ Online Lastschrift-Verfahren, also known as OLV, was an extension of ELV developed by some payment network operators that offered reduced risk by operating electronically (Bartsch, n.d.). During 2009, network operators, terminal suppliers and retail associations cooperated to bring the ELV/OLV networks into a combined, EC direct debit network (EHI Retail Institute, 2009, p. 18).

In 1992, the German banks introduced their own non-guaranteed, no-fee debit card payment system similar to ELV called Point of Sale ohne Zahlungsgarantie, also known as POZ (European Central Bank, 2007, p. 113). However, the POZ system did not experience similar success and falling usage levels and increasing fraud meant it was to be closed down by the ZKA at the end of 2006 (Germany to abandon signature debit, 2004, November 23).

\section{Stored-value cards and Geldkarte}

In order to update its financial law with trends in European law, Germany amended its banking law in 1997 to include issuing electronic money in the business of banks, thereby preventing other organisations from issuing it (Reszat, 2003, pp. 109-110). The ZKA piloted a stored value network, GeldKarte, in 1996, before judging the pilot successful and rolling the instrument out nationally in 1997 (CPSS, 2003, p. 159). Rollout of Geldkarte instruments was rapid and, according to the Bundesbank, there were 67 million Geldkarte cards in circulation by the end of 2001 with Geldkarte functionality being added to debit cards (Van Hove, 2004, pp. 13-14). ${ }^{33}$ The GeldKarte system operates with a proportional fee of $0.3 \%$ charged to merchants. Furche and Wrightson

\footnotetext{
32 As long as they notify of their card's loss promptly, cardholders are not generally exposed to similar amounts of risk. The card holder is generally not liable for any damage incurred as a result of card counterfeiting and can, in principle, contest account debits linked with unauthorised disposals. (Deutsche Bundesbank, 2009, p. 20).

33 In spite of the large roll-out, Van Hove (2004, p. 19) quotes Andreas Koebe, sales manager for SCard Service, the payment card services and marketing unit of Sparkassen-Finanzgruppe, is quoted saying that still "only about $2 \%$ or $3 \%$ of GeldKarte cardholders are active purse users".
} 
(2000, p. 42) report that, although it appeared they were "heavily" subsidising the system, ${ }^{34}$ banks faced an uproar from merchants about such “outrageously high fees.” According to Furche and Wrightson, this came in spite of market research showing the costs of the Geldkarte system faced by merchants were lower than the average cost of handling cash. Van Hove (2005, pp. 379-380) quotes GeldKarte Head of Marketing, Volker Koppe, as saying in 2005 that the payment network had begun focusing only on POS payments not attended by staff (he refers to POS attended by staff as, retail): "[w]e have completely left retail because we see that is very difficult to promote GeldKarte there".

\section{Further debit card developments}

Development of debit cards in Germany continued with networks being formed to provide for debit card instrument use across Europe. In 1993, the credit card companies, Europay International and MasterCard, launched the edc/Maestro network, which provided services for instruments to be used in Europe, through edc (European debit card), and around the world, through Maestro (Universal payment card is in for European boost, 1993, May 13). The edc network was merged with Maestro in 1998 (European Central Bank, 2007, p. 112) and, by 2003, the great majority of debit cards had Maestro and Electronic Cash badges, allowing them to be used with Maestro outside of Germany and with Electronic Cash inside it (Retail Banking Services Ltd, 2005b, p. 22; Country Survey - Germany: Cards test Germany's cash economy, 2007, May 18). In 2006, banks also started offering cards with badges for Visa's European debit card, V PAY, as well as for Electronic Cash (ibid). A number of developments occurred as part of the European development of SEPA (Single Euro Payments Area).

34 Possibly consistent with there being unprofitable subsidies for the system, van Hove (2004, p. 14) reports that Germany's private banks had been significantly less supportive of Geldkarte than the savings banks or the cooperative banks (represented by their associations). The former two groups of banks had issued $90 \%$ of Geldkarte cards with only the remainder issued by private banks. 
With it becoming SEPA-compliant, Germany’s Electronic Cash instrument was renamed Girocard in 2007 (Electronic Cash, n.d.). Around the beginning of 2007, one German banking group, Sparda, began issuing a SEPA-compliant Maestro card for both domestic and international transactions (i.e. not used with Girocard for domestic transactions) (Country Survey - Germany: Cards test Germany's cash economy, 2007, May 18). Also as part of SEPA, Germany introduced the EMV chip card standard, although, in a July 2009 monthly report, Deutsche Bundesbank reports (p. 53) that, in spite of EMV largely being adopted for ATMs and cards in Germany, only a very small percentage of merchant terminals were equipped with it.

\section{Other payment instruments}

In 2006, Germany's savings banks, co-operative banks and the country's postal bank partnered with online payments company, PayPal, to launch an online payment service, Giropay (German banks offer online payments, 2006, March 24). Giropay provides services that allow customers to pay for online purchases directly from their bank accounts, using the country's Giro system.

\subsubsection{Interventions in Retail Payment Systems}

During his summary of international regulatory scrutiny of card-based retail payment systems, Bos (2006, p. 753) describes the most important development, in terms of payment network interventions, as being the ZKA's 2000 application to the Bundeskartellamt, the Federal Cartel Office, for permission to introduce an interchange fee to all debit card payment systems The intention of the proposal was for banks to receive remuneration from merchants for the cost of maintaining consumers' cards and the infrastructure used for ELV transactions (OECD, 2007, pp. 158-159). The Bundeskartellamt let it be known that it was not in favour of the idea, believing that banks should recoup their costs through competition (ibid). Additionally, retailers' 
associations vehemently opposed the proposals, and, in April 2001, the banks withdrew their application (Australian Retailers Association, 2006, p. 42).

Early in 2006, the Hauptverband des Deutschen Einzelhandels or HDE (Central Association of German Retail Trade) made a complaint to the Federal Cartel Office, aiming to force Visa and MasterCard to cut their fees for credit card transactions (UPDATE 1-German retail group files credit card fees complaint, 2006, January 19). I have not found evidence showing the outcome of the complaint, although a website discussing German payment card events suggested the investigation was continuing in early 2010 (Paysys Consultancy GmbH, 2010, March).

\subsubsection{Data Showing Payment Instrument Adoption in Germany}

As with Canada, my key data source showing the adoption of debit and credit cards in Germany is the transaction and population data available from the Redbook publication, CPSS (2009), which provides estimates of issued transactions for the years 2004 to 2008. For the purposes of my calculations, I treat transactions on delayed debit cards and retailer cards with a payment function as credit or charge card transactions. CPSS (2009, p. 67) confirms that the debit card figures include ELV transactions, but also explains the minor decrease in the number of transactions in 2007 and 2008 observed in Figure 1.1 by reporting that figures for 2007 are estimates and that different methodology and data collection methods used since 2007 cause breaks when comparing 2007 and 2008 data with previous years' data. For the years 2000 to 2003, I use with data from an earlier Redbook, CPSS (2006). Although I do not include electronic money transactions in Figure 1.1, I use a figure from CPSS (2009) to calculate the number of Geldkarte transactions per capita for 2008 to use in my table showing features of major German merchant-based, card-based payment instruments.in section 3.3. 
Figure 1.1 shows Germany to have a substantially lower number of debit and credit card transactions per person than the other countries in my sample. For this reason, I have paid special attention to the veracity of the CPSS figures I use for Germany. My research has not confirmed or refuted the CPSS figures, yet it suggests that the CPSS data do underestimate debit and credit card adoption in Germany. The EHI Retail Institute (2009) provides data from a survey of retail payments made by card in Germany based on a sample of 406 companies with 55,000 branches with retail sales of 177.6 billion euros, which, according to the survey, represents $49 \%$ of total German retail turnover. The EHI paper reports (p. 15) that survey respondents reported 1,671 million debit card transactions in 2008, which is $89 \%$ of the CPSS statistic for transactions during 2008 for all of debit cards issued in Germany of 1,862 million. The significant difference between 49 and $89 \%$ does suggest issues with data. In further research, I found Deutsche Bundesbank (2009), which included details of a payments diary completed by 2,204 people for one week during 2008 . The article says (p. 47) that survey participants reported conducting a total of 2,907 transactions by debit card and 333 transactions by credit card during the survey's seven days. This suggests an average of 69 debit card transactions and 8 credit card transactions per person per year, which is well above the figure implied by the CPSS statistics of 23 and 5, respectfully.

\subsubsection{Bibliography for Summaries of Germany}

Australian Retailers Association. (2002, September 13). Submission to the Reserve Bank of Australia: Response to EFTPOS industry working group, Retrieved from http://www.rba.gov.au/payments-system/reforms/debit-card-systems/responses-discpaper/ara-130902.pdf

A rough ride for European EFTPOS. (1990, April 12). Banking Technology.

Bartsch, C. (n.d.). Payments at the POS. Retrieved on March 23, 2011 from http://english.zahlungsverkehrsfragen.com/subscribers/payments_at the pos.htm

Beck, T. (2003). The incentive compatible design of deposit insurance and bank failure resolution - concepts and country studies. World Bank policy research working paper, 3043, Retrieved from http://papers.ssrn.com/sol3/papers.cfm?abstract_id=636405 
Bos, P. (2006). International scrutiny of payment card systems. Antitrust law journal, $73,739-777$

Breitkopf, D. (2002, June 10). MasterCard: Deals won't change board's structure. American Banker, 167(117)

Brunner, A., Decressin, J., Hardy, D. and Kudela, B. (2004). Germany's three pillar banking system: Cross-country perspectives in Europe, Washington D.C.: International Monetary Fund, Occasional Paper 233

Buch, C. and Golder, S. (2001). Foreign versus domestic banks in Germany and the US: a tale of two markets? Journal of multinational financial management, 11, 341-361

Chemnitz University of Technology. (2008, June 22). Course information: SSO2, Electronic Banking, Retrieved from http://www.tuchemnitz.de/informatik/ThIS/downloads/courses/ss02/ebanking/02.htm

Committee on Payment and Settlement Systems [CPSS]. (2000). Survey of electronic money developments. Basel: Bank for International Settlements, CPSS Publications No 38, Retrieved from http://www.bis.org/publ/cpss38.pdf

Committee on Payment and Settlement Systems [CPSS]. (2003). Payment and settlement systems in selected countries. [Red Book], Basel: Bank for International Settlements, CPSS Publications No 53, Retrieved from http://www.bis.org/publ/cpss53.htm

Committee on Payment and Settlement Systems [CPSS]. (2006). Statistics on Payment and Settlement Systems in Selected Countries. Prepared by the Committee on Payment and Settlement Systems of the Group of Ten Countries, Publications No. 74, retrieved from http://www.bis.org/publ/cpss74.htm

Committee on Payment and Settlement Systems [CPSS]. (2009). Statistics on Payment and Settlement Systems in Selected Countries. Prepared by the Committee on Payment and Settlement Systems of the Group of Ten Countries, Publications No. 88, retrieved from http://www.bis.org/publ/cpss88.htm

Country Survey - Germany: Cards test Germany's cash economy. (2007, May 18). Cards international

Deutsche Bundesbank. (2009). Payment behaviour in Germany: An empirical study of the selection and utilisation of payment instruments in the Federal Republic of Germany, Retrieved from http://www.bundesbank.de/download/bargeld/pdf/bargeld_studie.en.pdf

Deutsche Bundesbank. (2009, July). Monthly report, Retrieved from http://www.bundesbank.de/download/volkswirtschaft/monatsberichte/2009/200907mb en.pdf

Deutsche Bundesbank. (n.d.). Retail Payment System (RPS). Retrieved on April 19, 2011 from http://www.bundesbank.de/zahlungsverkehr/zahlungsverkehr_emz.en.php

Electronic Cash. (n.d.). Girocard, Retrieved on April 19, 2011 from http://www.electronic-cash.de/en/girocard.html 
EHI Retail Institute. (2009). Card payment systems in retail 2009. Cologne: EHI Retail Institute e. V.

European Central Bank. (2007). Payment and securities settlement systems in the European Union: euro area countries, [Blue Book], Vol. 1, Retrieved from http://www.ecb.int/paym/market/blue/html/index.en.html

European Commission. (2006). Interim report 1: Payment cards, Sector Inquiry under Article 17 Regulation 1/2003 on retail banking, Retrieved from http://ec.europa.eu/competition/sectors/financial_services/inquiries/interim_report_1.pd $\underline{f}$

Furche, A. and Wrightson, G. (2000). Why do stored value systems fail? Netnomics: economic research and electronic networking, 2(1)

German debit interchange cost placed at DM250mn. (2001, January 29). Electronic payments international

German banks offer online payments. (2006, March 24). Electronic payments international

Germany passes important milestone. (2000, March 17). Cards international

Germany to abandon signature debit. (2004, November 23). Electronic payments international

Howells, J. and Hine, J. (eds) (1993). Innovative banking: Competition and the management of new networks technology, London: Routlege

MasterCard. (2011, February). Maestro intra-country interchange fees - Germany, Retrieved on April 19, 2011 from http://www.mastercard.com/us/wce/PDF/Germany.pdf

Organisation of Economic Cooperation and Development [OECD]. (2007). Competition and efficient usage of payment cards, DAF/COMP(2006) 32,

Overdrafts and debit dominate over credit. (2004, December 20). Cards international, London, p. 16

Paysys Consultancy GbmH. (2010, March). Events, Retrieved on March 16, 2011 from http://paysys.de/index.php?option=com_content\&task=view \&id=28\&Itemid=60

Plastic explosives: West German credit cards. (1987, July 4). The Economist, Iss. 7505, 80-81

Pohl, M. and Freitag, S., (1994). Handbook on the history of European banks, European Association for Banking History, Aldershot: Edward Elgar Publishing Company Ltd

PoS in Germany. (1984, October). Banking technology, London, 1(6), 17

Reszat, B. (2003). Financial reform in Germany. In Hall, M. (Ed.), The international handbook on financial reform, 88-112. Cheltenham: Edward Elgar Publishing Limited. 
Retail Banking Research Ltd. (2005a). Study of the impact of Regulation 2560/2001 on bank charges for national payments. Final report, Project $\mathrm{N}^{\circ}$ Markt/2004/11/F - LOT 2, Retrieved from http://ec.europa.eu/unitedkingdom/pdf/impact_en.pdf

Retail Banking Research Ltd. (2005b). Regulation 2560/2001: Study of competition for cross-border payment services. Final report, Project $N^{\circ}$ Markt/2004/11/F, Retrieved from http://ec.europa.eu/internal_market/payments/docs/reg-20012560/competition_en.pdf

Universal payment card is in for European boost. (1993, May 13). The Wall Street Journal Europe

UPDATE 1-German retail group files credit card fees complaint. (2006, January 19). Reuters news

Van Hove, L. (2004). Electronic purses in Euroland: Why do penetration and usage rates differ SUERF Studies, No. 2004/4, available: http://ssrn.com/abstract=575821

Van Hove, L. (2005). What future for electronic purses? In Lammer, T. Handbuch emoney, e-payment \& m-payment, Heidelberg: Physica-Verlag, 379-405

Visa. (2011, February). Domestic interchange reimbursement fees: Germany, Retrieved from

http://www.visaeurope.com/en/about_us/what_we_do/fees_and_interchange/interchang e_fees.aspx

Vittas, D. (1995). Thrift deposit institutions in Europe and the United States. Policy research working paper, 1540, Retrieved from http://www-

wds.worldbank.org/servlet/WDSContentServer/WDSP/IB/1995/11/01/000009265_3961 019154219/Rendered/PDF/multi_page.pdf

Waiting for the plastic revolution. (1997, November 28). Cards international

Welch, P. (2001, December 28). Big changes in German acquiring. Credit card management

Worthington, S. (1994). Retailer aspirations in plastic cards and payment systems. Journal of retailing and consumer services, 1(1), 30-39 


\subsection{New Zealand}

\subsubsection{Retail Payment Systems and Government Controls of Banking}

Holmes (1972) describes aspects of New Zealand's banking system in the period following World War 2. He reports that, during that time, the system was characterised by heavy regulation and control by the New Zealand Government. Holmes discusses at length (Chapters VI - X) the effects of controls placed upon New Zealand's financial industry, the members of which fell into three categories: trading banks (which Holmes also describes on p. 97 as commercial banks), trustee savings banks (thrift institutions administered by a trust) and other financial organisations (including building societies and finance companies). Holmes summarises the effects of the controls by saying (p. 79):

... the Government has, particularly since the mid-1930s, played an important part in controlling both directly and indirectly the activities of ... financial institutions. Its restrictive policies have had a particularly noticeable influence on the development of the trading banks in the post-war period, but they have also affected other institutions through controls over capital issues and hire purchase credit, restrictions on the interest rates which might be offered or charged, imposition of requirements to invest in government securities, and other measures.

Restrictions relevant to this thesis include limiting cheque issuance to trading banks (Holmes, 1972, p. 121), preventing the entry of new trading banks (Commerce Commission, 1980, para. 142) and preventing trustee savings banks from being heavily involved in corporate banking (Hayward, 1986, July 21).

In an effort to control the cost of the expanding use of cheques, in 1968 the trading banks created a jointly owned company, Databank Systems Limited (known as Databank) to spread the fixed costs of purchasing mainframe computers for processing new forms of cheques suitable for the newly created decimal currency and magnetic ink character recognition technology (Holmes, 1999, p. 110; Holmes, 1972, p. 103). In 1974, the Reserve Bank of New Zealand acted as an arbiter in negotiations that saw 
other financial institutions gain access to Databank on an agency basis (Reserve Bank of New Zealand, 1984, July 4, p. 4; De Lisle, 1985, July 4, p. 1).

A major trading bank, the Bank of New Zealand (BNZ), launched a Visa debit card in 1978 (National Business Review, 1979, February 7). Another trading bank, the National Bank, followed with a Visa credit card (Holmes, 1999, p. 187), while the other three trading banks, which were each Australian owned, introduced Australia's Bankcard to New Zealand (Commerce Commission, 1980, para. 11). In 1982, Databank started developing a new project, the Integrated Banking Information System, known as IBIS, which was designed to computerise the management of banking services for the customers of its owner banks' (Banks halt \$160m computer project, 1990, February 15).

In the second half of the 1970s, the New Zealand Government instituted various measures partly liberalising regulations in New Zealand's banking industry. Monetary policy changes introduced in 1976, including the removal of most interest rate controls, were seen as 'a great leap forward' towards deregulation (Holmes, 1999, p. 164).

Further removals of such controls were seen as having accorded savings banks a 'virtual freedom' by 1980. However, starting in 1981, substantial Government controls were exerted over banks and the New Zealand economy, including freezing wages, prices and interest rates in 1982 (Holmes, 1999, p. 168).

New Zealand's first ATM was deployed in 1979 (Reserve Bank of New Zealand, 2005, p. 40) and ATMs were increasingly used by customers, resulting in pressure for interconnection between banks' ATMs. After "some initial difficulty" with negotiations conducted through the New Zealand Bankers' Association, banks agreed to create a single national network of ATMs in 1985 (Holmes, 1999, p. 188). These agreements are believed to have included the payment of fixed interchange fees between banks, but 
banks did not generally charge their customers additional fees for using other banks' ATMs (Dr. David Tripe, Centre for Banking Studies, Massey University, 2010, May 24, personal communication).

In June 1984, a trustee savings bank, Auckland Savings Bank, began a pilot of an EFTPOS system (Smellie, 1984, June 28), a pilot that became known as Cashline. The trading banks' joint-venture, Databank, began a pilot of the Quicksmart EFTPOS system in late 1984 (Hayward, 1985, February 6). Documents available from the archives of the Reserve Bank of New Zealand show the Reserve Bank's interest in electronic payment instruments (known at that time in the country as electronic funds transfer or EFT). The documents make it clear that the different categories of organisations were very conscious of their relative standing (for an example, see Reserve Bank of New Zealand, 1984, March 29). The trading banks said that they were opposed to the idea of allowing other types of organisations direct access to the payments system and instead envisaged that "access would be available on an 'agency' basis ... under terms and conditions set down by the trading banks" (Electronic Funds Transfer Committee, 1984, December 3, p. 2). However, the trustee savings banks "strongly oppose the concept of an EFT payments system based on the existing Databank network and more generally reject the concept of a trading bank owned and managed EFT network in any form" (ibid, p. 2).

\subsubsection{A New Approach to the Regulation of Banks}

\section{Reforms of the 1984 Labour Government}

In July 1984, a Labour Government was elected in New Zealand, bringing a significant change to the regulation of the banking sector as part of wider reforms to the economy. In relation to financial sector regulations, the new Government reacted to the tight control exercised by the previous Government by floating the New Zealand dollar, 
abolishing controls on interest rates, foreign exchange trading and reserve asset ratio, removing Government guarantees of bank deposits and deregulating the banking industry. The Reserve Bank of New Zealand Amendment Act was passed in 1986 and came in to effect in 1987, opening the opportunity to register new banks subject to a company meeting explicit criteria (O'Shaughnessy, 1997, pp. 31-35; Hayward, 1988, July 20). According to Davis (1999, p. 21), “[u]nderpinning the approach [of the Act] were principles of achieving competitive neutrality, increasing contestability, and development of a prudential supervision policy consistent with economic efficiency."

Existing banks and new entrants became known as "registered banks" with the Government establishing explicit criteria and information requirements for the registration process that came into effect from April 1987. In July of that year, the Government announced that an initial group of eight institutions had been granted registered bank status (O'Shaughnessy, 1997, p. 53). This change, along with the abolition of regulations that hampered competition, led to a "blurring of the demarcation lines" between the different groups of institutions in the financial sector (ibid).

\subsubsection{Payment System Development Following the Reforms}

\section{A new approach to EFTPOS}

O'Shaughnessy (1997, pp. 37-41) argues the October 1987 sharemarket crash caused a significant change to operation of NZ banks by clearly demonstrating the importance of making profitable investment decisions in the newly deregulated environment. In the aftermath of the crash, O'Shaughnessy uses analysis of banks' costs to argue the crash bought on a drive for efficiency, stable profitability, an increased focus on operating 
costs and greater competition for profitable customers. ${ }^{35}$ In 1988, Databank's owners, the four former trading banks, reviewed the IBIS project after becoming concerned about the excessive costs associated with it. As a result of this review and because of continued concerns about costs, first the BNZ decided to withdraw from the Quick Smart network and the Australia \& New Zealand Banking Group Limited (ANZ) followed, causing a crisis shortly before Quicksmart was to merge with the Cashline network (Sir John Anderson, former Chief Executive, National Bank, 2009, November 3, personal communication; Bank of New Zealand is to pull out of the EFTPOS network, 1988, September 15).

The Cashline network was operated by Trustbank, Auckland Savings Bank (ASB Bank) and banks in Taranaki and Westland. Some evidence points to Cashline being cheaper for consumers than Quick Smart, although this idea was disputed at the time by Trustbank (Edmond, 1988, November 25). In February 1988, Trustbank, a member of the Cashline network, started offering merchants a small fixed payment each time a customer paid for a transaction using one of its terminals (Bank of New Zealand is to pull out of the EFTPOS network, 1988, September 15). These payments were based on negative interchange fees being paid for Cashline transactions (Peter McLeod, Chief Executive of EFTPOS New Zealand, 2009, October 22, personal communication).

The Databank owners that had not withdrawn from EFTPOS, namely National Bank and Westpac, purchased the Quicksmart network from Databank and renamed it, Handy-point. To be more competitive with alternative retail payment systems and attract greater merchant account business to their banks, National Bank and Westpac

35 O'Shaughnessy notes that registered banks' operating expenses as a percentage of operating income, which had been steadily increasing, peaked in 1989 and fell in four of the first five years of the 1990s. He attributes a reduction in banks' gross margins and net interest margins to this increased competition for profitable customers following the sharemarket crash. 
decided not to charge merchants per-transaction fees (Sir John Anderson, former Chief Executive of National Bank, 2009, November 3, personal communication). Merchants were already required to buy or rent EFTPOS terminals to accept EFTPOS transactions. All cardholders, however, were initially charged per-transaction fees and these ranged between NZ\$0.25-0.50 in the mid-1990s (Peter McLeod, Chief Executive of EFTPOS New Zealand, 2010, April 12, personal communication; Manual bank fees to rise, 1995, March 14).

In 1989, Handy-point and Cashline agreed to merge into a single network to be operated by a jointly-owned company, Electronic Transaction Services Limited ("ETSL”), using Handy-point's approach to merchant pricing. The merger was approved by New Zealand's competition regulator in September 1989 (Commerce Commission, 1989). One of the banks that had withdrawn from Quicksmart, the BNZ, eventually became an ETSL shareholder while the other, the ANZ, set up its own EFTPOS switch independent of ETSL, but which interconnected with ETSL's switch. ETSL's owners were happy to interconnect with ANZ's switch because they saw ETSL as simply providing a marketplace for banks' interaction (Tony Coulston, Head of Payments Industry Strategy, Westpac New Zealand, personal communication, 2010, May 5). A fixed switch fee paid by the issuer to the acquiring network for each transaction was negotiated to compensate the acquiring network for interconnection (Peter McLeod, Chief Executive of EFTPOS New Zealand, 2010, October 5, personal communication).

As EFTPOS transaction volumes increased, the nature of per-transaction fees changed somewhat. For consumers, bank accounts without fees for EFTPOS transactions became more prevalent. Matthewson and $\mathrm{Hu}$ (2006) analyse a mid-2005 survey of New Zealand bank customers, which investigated the fees paid by account holders to banks when making deposits, obtaining cash, transferring funds and paying third parties in the 
previous month. They report (p. 11) that $52 \%$ of respondents who had made EFTPOS transactions in the preceding month paid no fee. Their analysis of bank fees reported by major New Zealand banks (p. 7) shows EFTPOS transaction fees ranged from zero to NZ\$0.35 (with one outlier at NZ\$0.75). For merchants, ANZ attempted to introduce per-transaction fees for merchants for EFTPOS transactions in 1998. The higher fees were abandoned after ANZ lost a significant amount of merchant account business to banks who had not attempted to raise fees for merchants (Peter McLeod, Chief Executive of EFTPOS New Zealand, 2009, October 22, personal communication).

During 2006, one New Zealand bank, Westpac, introduced Visa Debit, a scheme-based debit card that could be easily used internationally and for distance payments, unlike New Zealand's domestic debit card network, EFTPOS. At the time of its introduction, a board of the company holding the license for Visa's New Zealand products and representing Visa's New Zealand members agreed to operate it without an interchange fee being paid between issuers and acquirers (Tony Coulston, Head of Payments Industry Strategy, Westpac New Zealand, personal communication, 2010, October 14).

\section{Other retail payment systems}

An alternative interbank payment system to Databank was started when ASB Bank helped to create the company, Payments Clearing Limited, in 1989 (Ex-Databank employee sets up rival operation, 1989, October 9). This alternative firm proved successful as "a stalking horse" by encouraging Databank's owners to open up Databank's system to faster processing of cheques (Tony Hood, former Chief Executive of Databank, 2009, October 24, personal communication). In 1990, the four Databank owners decided to abandon the IBIS project and to develop their own, internally developed information systems (Tough times in store for bank industry, 1990, July 24). Databank was sold to a computer technology company in 1993 and its interbank 
clearing activities were shifted to the company, Interchange and Settlement Limited (“ISL”) (Dr. David Tripe, Centre for Banking Studies, Massey University, 2009, 9 October, personal communication). Gradually, other banks joined the four original owners of ISL and ASB Bank did not continue with its development of Payments Clearing Limited (Tony Coulston, former Chairman of ISL, 2010, 7 September, personal communication). In 2010, the New Zealand banks announced the creation of a company owned by all of New Zealand's major banks, Payments NZ Limited, to ensure greater cooperation between banks over governance, including to allow the exchanging of account information when customers change banks and allow NBFIs access to New Zealand's payments system (New governance structure for bank payments system, 2010, December 15; Pullar-Strecker, 2011, March 14).

The relationship between banks following the reforms was not altogether smooth, however. The commonly accepted approach of not charging bank account holders for withdrawing cash from other banks' ATMs broke down in 1999 when one bank, Westpac, started charging its customers for using other banks ATMS (Diaz, 1999, August 25). Because charging customers for foreign ATM use meant the banks paid a smaller amount of interchange fees to its competitors, those competitors also began charging their customers foreign ATM fees in order not to lose money to cover their costs.

In 1996, six New Zealand banks created the New Zealand Mondex consortium when they bought equity in a joint venture to launch Mondex stored-value cards as a payment instrument (Brown, 1998, April 6). However, plans to jointly launch the system fell through and, in the end, only one bank, Westpac, trialled the product, although it did not continue with it (ibid). In 1999, another stored-value card system was proposed when the council-funded tourism organisation, Totally Wellington, looked to introduce a Visa 
system by mailing free cards to Wellington's 160,000 ratepayers, although the plan was not enacted (Newman, 1999, March 23; Burger, 1998, September 21). More success was had with a stored-value system when a private provider of bus services in Wellington, Infratil, introduced a stored value card called Snapper as part of its upgrade of bus ticketing systems in 2008 (Gabor Szikszai, Head of Marketing, Snapper Services, 2010, February 15, personal communication). As well as for bus tickets, the system also allows payments at participating merchants (who are required to fund a different type of terminal), who are charged an MSF of $1 \%$ of a transaction's value. A major New Zealand bank provided Snapper with important advice to extend Snapper's services in this way (Gabor Szikszai, ibid). The system has not experienced complete success, however, failing to be awarded a contract offered by local government for the installation of stored-value system on public transport in Auckland in 2009. After missing the contract, however, Snapper stated that it still planned to introduce the system to Infratil's Auckland buses during 2010. The introduction of the new system on buses was followed by the dismissal of nine bus drivers because the new system revealed they had been stealing cash fares under the buses' previous cash-based ticketing system (Williamson, 2009, July 9).

\subsubsection{Interventions in Retail Payment Systems}

In 2009, New Zealand's competition regulator, the Commerce Commission ("the Commission"), reached a settlement with Visa, MasterCard and their member banks and financial institutions regarding the networks' operations. Specifically, the settlements required that average interchange fees be reduced over a period of years, ${ }^{36}$ retailers be

\footnotetext{
36 Little information was released on the exact nature of the interchange fee decreases, although the associated Commerce Commission media release simply says, "significantly reducing the average interchange fees charged on New Zealand credit card transactions...”
} 
offered unbundled, unblended MSFs ${ }^{37}$ and retailers be allowed to surcharge for credit card transactions. The Commission believed these actions would cause issuers to set interchange fees in competition with each other. The settlements also explicitly defined criteria for access to networks issuing Visa and MasterCard payment cards for financial and non-financial entities. Although only a limited amount of time has progressed since the Commission's settlements, initial evidence indicates that the majority of merchants are not surcharging credit card transactions (New Zealand Herald, 2010, February 1). Indicating its discomfort with the nature of surcharging that was starting to occur, however, the Commission issued a press release (2010, January 12) that said it was "taking a close interest in the surcharges some retailers have introduced" and "watching developments to ensure that the long-term interests of consumers are being served."

\subsubsection{Data Showing Payment Instrument Adoption in New Zealand}

To measure the level of debit and credit card adoption in New Zealand, I have used data from the Electronic Card Transactions series, maintained by Statistics New Zealand (2010a), which provides information for acquired transactions. I combine this data with population data as measured by the Total Estimated Resident Population also from Statistics New Zealand (2010b) to calculate the number of transactions per capita.

\subsubsection{Bibliography for Summaries of New Zealand}

Bank of New Zealand is to pull out of the EFTPOS network. (1988, September 15). New Zealand herald

Banks halt \$160m computer project. (1990, February 15). National business review Brown, R. (1998, April 6). Kiwi banks back off Mondex launch. Computerworld New Zealand

Burger, A. (1998, September 21). Australia's smart card waltz. Card technology news

37 The Commission hopes such fees allow retailers to be charged merchant service fees commensurate with interchange fees that are charged for particular MasterCard and Visa cards. 
Commerce Commission. (1980) An inquiry into bank cards, Report of the Commerce Commission, 14 February

Commerce Commission. (1989, September). Commerce Act 1986, Merger or Takeover Proposal: Electronic Transactions Services Limited

Commerce Commission. (2009, October 5). Credit card settlements lower New Zealand business costs, media release no. 33, Retrieved from

http://www.comcom.govt.nz/media-

releases/detail/2009/creditcardsettlementslowernewzeala

Commerce Commission. (2010, January 12). Commerce Commission watching retailers' credit card surcharges, media release no. 69, Retrieved on from http://www.comcom.govt.nz/media-releases/detail/2010/commerce-commissionwatching-retailers-credit-card-surcharges/

Davis, K. (1999). Reform of Australian and New Zealand financial markets. In de Brouwer, G. and Pupphavesa, W. (eds) Asia Pacific financial deregulation, New York: Routledge, Retrieved from http://kevindavis.com.au/secondpages/AUSTRALIAN\%20FINANCIAL\%20SECTOR. $\underline{\mathrm{htm}}$

De Lisle, P. L. (1985, July 4). Memorandum for the Assistant Governor: Electronic funds transfer system, Banking and Currency Department, Reserve Bank of New Zealand Knowledge Centre

Diaz, D. (1999, August 25). Bank plans fee for rival ATM use. New Zealand herald

Edmond, S. (1988, November 25). Bank of New Zealand withdrawal from system throws a spanner in works; EFTPOS still has a future, partners say. National business review, Weekend review

Electronic Funds Transfer Committee. (1984, December 3). Memorandum for the Economic Advisory Committee, Reserve Bank of New Zealand Knowledge Centre

Ex-Databank employee sets up rival operation. (1989, October 9). National business review

Hayward, D. (1985, February 6). NZ banks set up EFTPOS system. Financial times. International, p. 21.

Hayward, D. (1986, July 21). Survey of New Zealand (9): Merger brings big advantages / Trustee Banks. Financial times, London, p.V.

Hayward, D. (1988, July 20). Survey of New Zealand (8): Full force of competition Banking deregulation. Financial times

Holmes, F. (1972) Money Finance and the Economy: An Introduction to the New Zealand Financial System, Auckland: Heinemann Educational Books (NZ) Limited

Holmes, Sir Frank. (1999) The thoroughbred among banks in New Zealand: 1945-1984, vol. 2, Wellington: The National Bank of New Zealand Limited 
Kiwibank chief mulls account number portability. (2010, October 5). New Zealand herald

Matthews, C. and Hu, M. (2006). The fees people pay. Paper presented at the 19th Australasian Finance and Banking Conference, Sydney, 13-15 December 2006

Manual bank fees to rise. (1995, March 14) New Zealand herald

New governance structure for bank payments system. (2010, December 15). New Zealand press association

Newman, K. (1999, March 23). Capital waits for banks for go-ahead. New Zealand herald

O'Shaughnessy, E. (1997). Financial sector deregulation in New Zealand 1984 - 1990, Thesis for Master of Commerce and Administration degree, Victoria University of Wellington

Pullar-Strecker, T. (2011, March 14). New switch rules bypass need for bank number portability. Manawatu Standard

Reserve Bank of New Zealand. (1984, March 29). E.F.T. systems: Notes on a meeting between the Reserve Bank and the New Zealand Bankers' Association, Reserve Bank Knowledge Centre

Reserve Bank of New Zealand. (1984, July 4). Memorandum for the Directors: Electronic funds transfer systems, Chief Cashier's Department, Reserve Bank of New Zealand Knowledge Centre

Reserve Bank of New Zealand. (2005, May). Financial stability report, retrieved from http://www.rbnz.govt.nz/finstab/fsreport/fsr_may2005.pdf

Shops shun credit charge. (2010, February 1). New Zealand herald

Smellie, P. (1984, June 28). Cashless society makes NZ debut. The dominion.

Statistics New Zealand. (2010a). Electronic card transactions: Nov-02 to Mar-10, retrieved on April 22, 2010 from Statistics New Zealand

Statistics New Zealand. (2010b). Resident population estimates: 1991 to 2009 as at 30 June, retrieved on April 22, 2010 from

http://www.stats.govt.nz/browse_for_stats/population/estimates_and_projections.aspx

Taylor, P. (2010). New Zealand's market-based solution to interchange fees.

Presentation to Cards \& Payments Australasia 2010 Conference, 15 March 2010, Retrieved from http://www.comcom.govt.nz/cards-and-payments-australasia-2010conference-15-march-2010/

Tough times in store for bank industry. (1990, July 24). National business review Williamson, K. (2009, July 9). Police look into bus drivers' fare thefts. Dominion post 


\subsection{Norway}

\subsubsection{Retail Payment Systems and Government Controls of Banking}

For much of the period following World War 2 until the 1970s, the Norwegian

Government placed substantial restrictions on the operation of the economy and on banks (Ecklund and Knutsen, 2001). They argue that formal and informal rules rationed demand for credit by controlling both investment and interest rates. Furthermore, the report that the Government even encouraged a system of price cartels, which benefitted the established firms by drastically reducing competition.

A giro system also developed in Norway with the postal network's Postgiro being

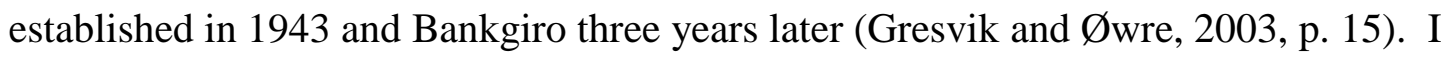
have found little further evidence on the exact nature of Norway's giro networks, prior to the introduction of electronic giros. The bank owned, not-for-profit joint venture, Bankenes BetalingsSentral AS (BBS), was established in 1973 to operate a clearing house for Bankgiro payments (Office of Fair Trading, 2005, p. 237). In the late 1970s, Norwegian banks also established ATM services (Gresvik and Øwre, 2003, p. 15). Enge and $\varnothing_{w r e}(2006$, p. 169) cite Norwegian Government reports that consider national card networks published as early as 1974. However, they report (p. 167) that cards were not introduced for (direct) payment in Norway until the early 1980s:

Oil companies were the first to introduce card payments in Norway (each company had its own card). In 1982 the Banking Association entered into framework agreements with oil companies on the use of banks' cards (ATM cards) in the oil companies' terminals. The first bank-operated card payment project took place in 1983/84 at the OBS department store at Løren, Oslo.

Hirsch (1984, p. 7) describes how the savings banks joined with one oil company, Shell, to create a network using the banks' ATM cards, which became operational in September 1981. Another oil company, Esso, and the commercial banks followed with a network in the autumn, 1983. By late 1984, the two networks had agreed to 
interconnect, allowing the use of one card in both. Hirsch also mentions a small scale EFTPOS pilot in Norwegian supermarkets and initial trials of a card based on a chip rather than on a magnetic strip.

\subsubsection{A New Approach to the Regulation of Banks: Deregulation and Crisis}

Norway experienced a process of deregulation, starting gradually in the late-1970s and gathering pace during the early- to mid-1980s. Ecklund and Knutsen (2001, p.20) comment that:

The highly interventionist old model of selective credit regulation was not scrapped in one formal decision, but rather through a process of several decisions stretching over a period of ten years.

From 1984, Norway allowed foreign banks to enter its banking market (Jacobsen and Tschoegl, 1999, pp. 148-149). Up until the mid- to late-1980s, banking regulators in the Nordic countries had forced banks with international operations to use legally distinct subsidiaries or partnerships with other banks. After that time, the regulators began to permit their banks to use branches abroad, increasing the level of competition in Norway.

However, from 1987-92, the Norwegian banking system experienced a near collapse, resulting in major injections of funding by the Norwegian Government and the nationalisation of three major banks. ${ }^{38}$ As a result of the crisis, the Bank Guarantee Act was passed to shore up confidence in the banking system (Mayer Brown, 2009, September 8, p. 1). Two of the nationalised banks were sold in 1995 and 2000, while the Government retained a 34\% stake in the third (Atle Berg and Eitrheim, 2009, p. 5).

38 For an in-depth summary of the crisis, its causes and consequences, see Ecklund and Knutsen (2001). 


\subsubsection{Payment System Development Following the Reforms}

In the mid-1980s, there were three debit card systems in Norway: commercial banks issued cards with microprocessor chip technology, whereas the two systems operated by the savings banks and Postbanken, the Norwegian Post Bank, issued cards with magnetic strip technology (Enge and $\emptyset_{w r e}, 2006$, p. 167). At this time, the central bank, Norges Bank, worked to increase coordination by, amongst other things, creating the Technical Reporting Committee on Payment Systems. In 1986, the two banking associations reached an agreement with retail organisations to install POS terminals. However, according to Enge and Øwre (2006, p. 167), the organisations found it difficult to reach a coordinated solution:

... partly because of the costs of preparing terminals that could read both chips and magnetic stripes [sic], partly because of different views on the security aspects of the different solutions, and partly for market strategy reasons.

Indeed, the UK Office of Fair Trading (2005, p. 238) comments that "Norges Bank was instrumental in facilitating the merger of the three schemes, as the banks were unable to reach agreement amongst themselves." This quote appears to be contrary to the evidence discussed above that agreements were reached to link the POS payment networks used by the oil companies. Whatever the underlying cause, however, the banks succeeded in creating a new POS debit card payment network, BankAxept, one that relied on explicit pricing for consumers of payment instrument use.

\section{Explicit pricing and BankAxept}

Enge and Øwre (2006) describe the development from the 1970s to the 1990s of the institution of charging consumers, rather than merchants, for the use of payment instruments. To begin with, banks and public authorities gradually promoted charges to consumers for the use of cheques, although the practice was resisted by trade unions. During the Norwegian banking crisis, authorities encouraged charging for payment 


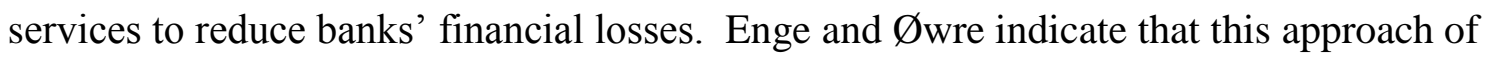
charging consumers for instrument use contributed significantly to the development of Norway's domestic debit card payment system, BankAxept.

BankAxept AS was created following the banking associations reaching an agreement in 1991 for a jointly-owned company responsible for operating the system, choosing its technology and approving the types of terminals to be linked to the network (Enge and Øwre, 2006, p. 168). In 1992, BankAxept commenced operations, with a magnetic strip becoming standard on its cards (Norges Bank, 2007, p. 9). BankAxept was developed with cardholders and merchants paying fees to their banks and merchants paying rental for terminals, but without any (positive or negative) interchange fees (Norges Bank, 2006a, Answer to Question 50). Gresvik and Haare (2009b, p. 24) comment that BankAxept "mainly charges merchants for the rental of the terminal and, in some cases, a flat fee per transaction of a few øre $(1 \mathrm{NOK}=100$ øre $) .{ }^{, 39}$ Based on a survey of fees charged by banks for BankAxept transactions (Norges Bank, 2006b, p. 24), Norwegian consumers generally pay a transaction fee of 2.00 to $2.50 \mathrm{NOK}$, with only four out of 24 banks charging less than $2.00 \mathrm{NOK}^{40}$

In 1996, once it was satisfied that there were appropriate arrangements for inclusion of the system operated by Postbanken, the Ministry of Finance approved the agreement for

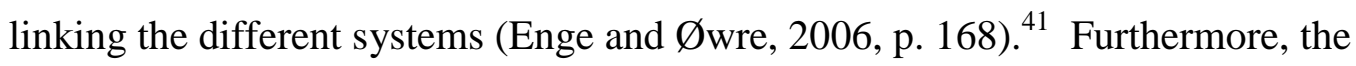
government does not appear to have been involved when the banks arranged to

\footnotetext{
39 Norges Bank (2010, p. 11) indicates BankAxept MSFs are slightly higher when it says the fee normally charged is approximately between NOK 0.12-0.20.

40 Using the average exchange rate for 2006, 1 NOK = US\$0.16 (Source: OANDA, 2011).

41 Although not initially approved by the Ministry of Finance, an agreement was reached in 1992 allowing Postbanken customers to use their cards in BankAxept terminals.
} 
introduce EMV chip technology to Bankaxept terminals and cards, which was expected to happen by 1 April 2009 (Konkurransetilsynet, 2009, p. 93). ${ }^{42}$

Although BankAxept terminals are also able to accept other cards, BankAxept is primarily a domestic debit card network with limited use abroad (Kredittilsynet, 2004, p. 17). However, most BankAxept cards can also function as an international payment card; these cards are referred to as combined cards and allow greater use outside of Norway. I have not found evidence on when international payment cards were introduced in Norway, although Norges Bank (2010, p. 11) does suggest a date by which they had been introduced when it notes that, for such cards, "[f]ees charged to merchants have fallen gradually since the mid-1990s." In regard to merchants' fees, it is important firstly to note that, within Norway, most merchants' terminals are programmed to prefer BankAxept whenever possible (Kredittilsynet, 2004, p. 17). If BankAxept is not available, however, merchants incur MSFs of a proportional nature, with Norges Bank (2008, p. 14) supplying average MSFs and interchange fees. Kaardal, Ryste and Solberg (2007, p. 10) clarify that the merchants are commonly charged the same MSF for Visa and MasterCard transactions, regardless of whether they involve a credit or a debit card, an approach they say is not common in other European Union countries and one that comes in spite of interchange fees in Norway for credit card transactions being approximately twice as high as those for debit card transactions. ${ }^{43}$ Credit card use has been limited as Norwegian banks have traditionally offered credit through overdrafts; though in recent years banks have begun to issue credit cards (Office of Fair Trading, 2005, p. 233). Norges Bank annual reports do,

42 Translation from Norwegian to English provided by Anton Nannestad (2011, March 4).

43 Translation from Norwegian provided by Anton Nannestad (2010, May 11, personal communication). 
however, indicate that a small number of transactions completed using domestic credit card networks, although I have not found any evidence of their development.

\section{Other retail payment systems}

In 1988, following the difficulties of one small bank meeting its obligations, the Norwegian banks decided to establish a new interbank retail payment system to be operated by the bank-owned joint venture, BBS, the Norwegian Interbank Clearing System (NICS). Following that decision, development was slowed by the Norwegian banking crisis, with the system not beginning operations until 1993. It clears over $90 \%$ of Norway's retail transactions, including debit card payments, cheques, giro credits and direct debits (Office of Fair Trading, 2005, p. 236). ${ }^{44}$ In checking the ease of access to payment networks, European Free Trade Association Surveillance Authority (2008, p. 64) reports that no request for membership of NICS has been refused, although it reports that there are a number of other systems operated by individual banks, such as DnB NOR Bank ASA, and smaller banks do not directly need to use NICS (Norges Bank, 2005, p. 37).

In addition to the NICS interbank network, the giro system continued to develop from the perspective of consumers. In 1992, Giromail and the telephone giro were launched and the Postgiro and Bankgiro systems were merged in 1996, creating a common system, and PC/Internet giro services were launched the same year (Gresvik and Øwre, 2003, p. 15). The Norwegian banks launched a domestic bill payment system branded eFaktura in 2000 (Office of Fair Trading, 2005, p. 247). The system functions as a billing information service, assisting users making internet giro payments (Gresvik and Haare, 2009a, p. 22).

44 Visa and MasterCard credit and charge card transactions are cleared and settled using each schemes' own systems. 
In 1995, Norges Bank established the Cash Card Forum, to be chaired by it and to have members from the transport, communications and banking sectors (Norges Bank, 1999, December, p. 29). A number of tests of stored-value systems occurred in the late 1990s, including of the Mondex system, but the Forum did not appear to meet again after 1998 (Norges Bank, 2000, pp. 13, 33). In accordance with the two Directives issued in 2000 by the European Commission on the issue, the Norwegian Parliament passed the Act concerning Electronic Money Institutions in 2002 (Kredittilsynet, 2008, provides an English translation of the Act). Along the lines of prudential regulations for banks, the Act specifies prudential and operational standards that organisations issuing electronic money must meet, with the rules to be administered by the Kredittilsynet, the Financial Supervisory Authority.

\subsubsection{Interventions in Retail Payment Systems}

As discussed above, the Norwegian Government has traditionally adopted an interventionist approach to the country's economy. During the first decade of this century, the Norwegian authorities have taken a number of actions consistent with that. The Financial Contracts Act, passed by the Norwegian Government in 2000, outlawed banks keeping float income ${ }^{45}$ associated with payment system use (Office of Fair Trading, 2005, p. 242). The legislation was supported by, amongst others, consumer groups and the Norges Bank who viewed float income as not encouraging transparency or efficiency. Office of Fair Trading (2005b, p. 242) notes that modifying systems to remove float income did not require any modifications to the NICS payment system; only changes to internal bank systems. In two incidents, authorities voiced concerns about the operation of retail payment systems, possibly indicating a willingness to intervene. In 2004, Kredittilsynet (the Financial Supervisory Authority) published a

45 Float income is defined as the interest income from the time between when the financial intermediary collects the payment from the payor and passes it to the payee (Thompson, 2009, p. vi). 
report considering the regulation of international card companies' fees. While the report did not recommend regulation, it suggests intervention may be warranted in the setting of interchange fees and the use of the No-Surcharge Rule ${ }^{46}$ (p. 43):

If the competitive situation and price level in the acquirer market does not improve after the observation period is over, however, the project group will recommend that the Ministry of Finance evaluates regulating the interchange fee. In addition, it may be in place for the Norwegian Competition Authority to evaluate the legality of some competition-limiting clauses in the contracts between acquirers and merchants. This will apply in particular to the nodiscrimination clause.

The report did not make any recommendations regarding the Honour-All-Cards rule, ${ }^{47}$ instead saying that (p. 41) its abolition "probably has no practical significance in the Norwegian market today."

In a media release in 2008 (May 8), Norges Bank complained that some banks were reducing prices for many payment services or offering them free of charge. The press release says that Norges Bank Governor, Svein Gjedrem, had said that this was "not in bank customers' best interests", before adding:

A reduction in earnings may reduce banks' capacity and willingness to invest in improved infrastructure. Furthermore, without cost coverage, payment services will have to be financed by earnings from other services. This sends the wrong signal to customers and may result in the inefficient use of resources.

In addition to the above actions, authorities have shown an interest in improving the integration of the six Nordic countries (Norway, Sweden, Denmark, Finland, the Faroe Islands and Iceland) (for example, see Nordic Competition Authorities, 2006). Consistent with this interest, Norwegian authorities have questioned access to Norwegian retail payment systems. In 2003, the Norwegian competition authority, Konkurransetilsynet, found that an agreement giving BBS exclusivity for acquiring 
EFTPOS transactions was contrary to competition rules because it prevented banks from unilaterally choosing to use other acquirers (Nordic Competition Authorities, 2006, p. 45). Nevertheless, European Free Trade Association Surveillance Authority (2008, pp. 64-65) reports that, while the governance structure of payment systems and the structure of the fee systems may raise entry barriers for smaller players, "this only seems to apply to a very limited extent..."

In spite of the suggestions of interventions describe above, at least one authority has shown a pragmatic approach to direct payment system regulation. Konkurransetilsynet (2009, p. 96) argues that an increase in the availability of different types of payment cards gives more freedom to cardholders, which it argues leads to an increase in price competition for cardholders between the various card companies. ${ }^{48}$

\subsubsection{Data Showing Payment Instrument Adoption in Norway}

To measure the level of debit and credit card adoption in Norway, I have used data on the volume of issued transactions and population from the 2007 Norges Bank Annual Report on Payment Systems (Norges Bank, 2008), because that data was available in spreadsheet format. To obtain data for 2008 and 2009, I used the 2009 Norges Bank Annual Report on Payment Systems (Norges Bank, 2010). For several observations for the year 2007, I use data from this latter report, in place of data from the 2007 Annual Report because of minor inconsistencies. The information presented for card transactions made in other countries using Norwegian cards does not distinguish between debit and credit cards. Accordingly, I am able to calculate total issued transactions on debit and credit cards for Figure 1.1, but not for my table in section 3.5. For these, I calculate only the number of transactions made on Norwegian cards in Norway. Furthermore, the Norges Bank category of "Cards issued by international card 
companies" does not distinguish between credit cards and debit cards, so I assume all are credit/charge card payments. I confirmed my interpretation of the statistics in personal communication with a Norges Bank employee, Harald Haare, on February 5, 2011.

\subsubsection{Bibliography for Summaries of Norway}

Atle Berg, S. and Eitrheim, Ø.. (2009). Bank regulation and bank crisis: The main developments in the Norwegian regulatory system before, during and after the banking crisis of 1988-92, Working Paper 18, Norges Bank, Bicentenary Project

Ecklund, G. and Knutsen, S. (2001). Protection against crises? A century of financial supervision in Norway, Retrieved on 15 March 2010 from http://www.finanstilsynet.no/Global/English/About_us/History/Protection-againstcrises-summary2001.pdf

Enge, A. and Øwre, G. (2003). A retrospective on the introduction of prices in the Norwegian payment system, Economic Bulletin 4/06, 77, 162-172

European Free Trade Association Surveillance Authority. (2008). Retail banking sector inquiry concluding report, Case No. 58717, Event No. 454106, Retrieved from http://www.eftasurv.int/

Gresvik, O. and Haare, H. (2009a, May 14). Costs in the Norwegian payment system: Questionnaires, Norges Bank Staff Memo No. 5/2009, Retrieved from http://www.norgesbank.no/upload/publikasjoner/staff\%20memo/2009/staff_memo_0509.pdf

Gresvik, O. and Haare, H. (2009b). Costs in the payment system, Norges Bank economic bulletin, 1/2009, Vol. 80, pp. 16-27

Gresvik, O. and Øwre, G. (2003). Costs and income in the Norwegian payment system 2001: An application of the Activity Based Costing framework, Working paper ANO 2003/8, Financial infrastructure and payment systems department, Norges Bank, Retrieved on 15 March 2010 from http://www.norgesbank.no/templates/report_47896.aspx

Hirsch, P. (1984, November/December). EFT-POS: a European overview, The World of Banking, pp. 6-12.

International Monetary Fund. (2005, June). Norway: Financial system stability assessment, IMF country report No. 05/200, Retrieved from http://www.imf.org/external/pubs/ft/scr/2005/cr05200.pdf

Jacobsen, S. and Tschoegl, A. (1999). The Norwegian banks in the Nordic consortia: A case of international strategic alliances in banking, Industrial and corporate change, $8(1)$ 
Kaardal, K., Ryste, K. and Solberg, I. (2007). Ny vurdering av markedet for internasjonale betalingskort $i$ Norge [New assessment of the market for international payment cards in Norway]. Kredittilsynet, Norwegian Competition Authority and Norges Bank, available at http://www.kredittilsynet.no

Kredittilsynet [Financial Supervisory Authority]. (2004). Regulation of the international card companies'fees, Public version, Retrieved from http://www.kredittilsynet.no/archive/f-avd_word/01/04/Regul011.doc

Kredittilsynet [Financial Supervisory Authority]. (2008). Act concerning Electronic Money Institutions. English Translation, ACT 2002-12-13 No. 74, Retrieved from http://www.finanstilsynet.no/Global/English/Laws_and_regulations/Banking_finance/A ct_E-money_Institutions.pdf

Konkurransetilsynet [Norwegian Competition Authority]. (2009). Konkurransen i Norge [Competition in Norway], Retrieved from http://www.konkurransetilsynet.no/no/Publikasjoner/Ovrigepublikasjoner/Konkurransen-i-Norge/

Mayer Brown. (2009). Summary of government interventions in financial markets: Norway, Retrieved from http://www.mayerbrown.com/publications/article.asp?id=7855\&nid=6

Nordic Competition Authorities (Danish, Faroese, Finnish, Icelandic, Norwegian and Swedish Authorities). (2006). Competition in Nordic retail banking, No. 1/2006, Retrieved from http://www.kilpailuvirasto.fi/tiedostot/Nordic_Retail_Banking.pdf

Norges Bank. (1999). Annual report on payment systems 1998, Retrieved from http://www.norges-bank.no

Norges Bank, (2000). Annual report on payment systems 1999, Retrieved from http://www.norges-bank.no

Norges Bank. (2006a). Consultative paper on SEPA incentives, Letter from Norges Bank to the European Commission. Internal market and services DG - Financial institutions, Retrieved on 2011, April 20 from http://www.norgesbank.no/no/om/publisert/brev-og-uttalelser/2006/submission-2006-04-25html/

Norges Bank. (2006b). Annual report on payment systems 2005, Retrieved from http://www.norges-bank.no

Norges Bank. (2007). Annual report on payment systems 2006, Retrieved from http://www.norges-bank.no

Norges Bank. (2008). Annual report on payment systems 2007, Retrieved from http://www.norges-bank.no (including Excel tables for statistics from http://www.norges-bank.no/Upload/69230/Tables_2007.xls)

Norges Bank. (2008, May 8). Payment services free of charge are not in bank customers' best interests, Norges Bank, Press Release, Retrieved from http://www.norges-bank.no/en/om/publisert/pressemeldinger/2008/pressemelding-8mai-2008-nynorsk/ 
Norges Bank. (2010). Annual report on payment systems 2009, Retrieved from http://www.norges-bank.no

Office of Fair Trading (United Kingdom). (2005). BPSL Innovation Working Group report prepared for the Payment Systems Task Force, OFT789b, Retrieved from http:// www.oft.gov.uk/shared_oft/reports/financial.../oft789b.pdf 


\subsection{United Kingdom}

\subsubsection{Retail Payment Systems and Government Controls on Banking}

As Schooner and Taylor (1999) describe, successive British Government allowed the banking industry to exist under an informal approach to banking regulation during much of the second half of the twentieth century. The country's central bank, the Bank of England, preferred dealing in an informal manner with a limited number of banks rather than a more formal, prescriptive approach to banking supervision. ${ }^{49}$ Gowland (2003, p. 254) describes how new entry was difficult and the Bank of England encouraged a club with a closed group of players to develop. The UK started to break away from this system following a 1973-74 banking crisis and a 1977 directive from the European Economic Community caused the British Government to implement a formal system of bank monitoring by passing the Banking Act 1979. The Act created a two-tier system of banking supervision for "recognised banks" and licensed deposit takers, imposing more specific supervision criteria on the latter, while allowing the Bank of England to continue its informal, flexible, case-by-case approach to the former (Schooner and Taylor, 1999, pp. 630-631).

\section{Charge cards and credit cards}

The Diners Club card began operations in the UK in the early 1950s with American Express first issuing cards in the UK in 1963 (Monopolies and Mergers Commission, 1980, paras. 2.10-2.12). In 1955, Barclays Bank formed the view that, with sufficient demand, a credit card could become part of its service offering. However, it was not until 1965 that the company decided demand was enough to begin issuing Barclaycard and became the first international issuer of BankAmericard (later to become Visa

$49 \quad$ As an example, Schooner and Taylor (1999, p. 621) note that the Bank of England has never actually issued a formal directive to the banks it supervised, in spite of having the power to do so in the period following the Second World War. 
International). ${ }^{50}$ The Monopolies and Mergers Commission (paras. 2.10-2.13) reports that other clearing banks were unconvinced that the Barclaycard would prove profitable and introduced cheque guarantee cards, instead. However, by 1970, it had become apparent to three of these banks that the Barclaycard was having a large impact on their business, leading them to eventually create the Joint Credit Card Company Limited (JCCC) and issue the Access card from 1972 (ibid). ${ }^{51}$

\section{ATM and direct entry payment networks}

Barclays Bank installed arguably the world's first ATM in its Enfield retail branch in June 1967 (Bátiz-Lazo, 2009, p. 6). A large amount of technological improvement followed with banks creating a base of installed ATMs and adding to their functionality. From 1982, groups of banks and NBFIs started sharing ATM arrangements to give their depositors access to a larger number of ATMs than just those owned by their organisation (Bátiz-Lazo, 2009; Rob Walker, former Manager, Business Services, EFTPOS UK, 2010, May 20, personal communication). One group, which initially included banks and building societies, the government-owned National Giro bank and American Express, established the jointly-owned firm, LINK, in 1985, which was to subsequently become the dominant ATM service provider in the UK (Bátiz-Lazo, 2009, p. 17).

In 1968, two major developments occurred that aided retail funds transfers between banks. The Inter-bank Computer Bureau was created to process inter-bank direct entry transactions (Rollason, 1989, p. 13) and the National Giro Centre was established to help the UK Post Office copy its European counterparts by offering funds transfers through Post Office branches (Bátiz-Lazo and Wood, 2002, p. 196). From the first

\footnotetext{
50 The Barclaycard was first issued in 1966 (Cruickshank, 2000, para. 3.6).

51 The Access card would become associated with the Interbank Association and eventually become MasterCard.
} 
organisation, Bankers' Automated Clearing Services Limited (BACS), a company jointly owned by members of the Committee of London Clearing Bankers, emerged in 1971. ${ }^{52}$ The giro, meanwhile, "had never been more than a pale copy of its German model" and the organisation that operated it was sold to private interests in 1993 (Gowland, 2003, p. 268).

In spite of the progress on ATMs and interbank transfer systems, less progress was made on a debit card-based payment system. Initial investigations of the development of such a system began in 1974 (Howells and Hine, 1993, pp. 24-25). Work did not start on such a system until 1985 and the intervening years saw a number of working parties and review groups producing reports that failed to convince the banks to implement a national network (Howells and Hine, ibid; Rob Walker, former Manager, Business Services, EFTPOS UK Limited, 2010, May 20, personal communication).

In March 1984, the British banks published the Child Report, named after its author, Denis Child, in response to criticisms that they were refusing to grant new entrants access to payment systems (Duggan and Karpinski, 1988, pp. 35-36). A central recommendation of the Child Report was for "fair and explicit" criteria for the admission of companies to interbank infrastructure for payment systems (Rob Walker, former Manager, Business Services, EFTPOS UK, 2010, May 20, personal communication). The Association for Payment Clearing Services (APACS) was set up in 1985 as a non-statutory association of the major banks and building societies (Ashton and Boyes, 2002, p. 211). APACS became an umbrella organisation for BACS, the Cheque and Credit Clearing Company Limited (C\&CCC) and Clearing House Automated Payment System Limited (CHAPS). C\&CCC was created in 1985 for

52 In 1986, the name of the company was shortened to BACS Limited, to take account of a widening ownership. 
cheque and giro clearing while CHAPS started operations in 1984 for large-value, wholesale payments in sterling (Cheque and Credit Clearing Company Limited, n.d.; UK Payments Administration, n.d.). Yet some access problems appeared to remain: according to Duggan and Karpinski, two consortia of building societies applied to join BACS in 1984, but were refused entry.

\subsubsection{A New Approach to the Regulation of Banks}

\section{Re-regulation rather than deregulation}

The removal of exchange controls in 1979 and quantitative controls on bank lending were the start of some deregulatory change in the UK (Matthews, Murinde and Zhao, 2007, p. 2026). Care should be taken, however, not to describe the process as dramatic; for example, Gowland (2003, p. 272) describes banking legislation passed in 1979 as "neither deregulatory nor increased regulation but the move towards a more formal system [that] was in a sense deregulation." Legislation removed some distinctions that existed between financial organisations: one major example was the Building Societies Act 1986, which allowed building societies to diversify their business portfolios and put them on a similar footing to the clearing banks (Bátiz-Lazo, 2009, p. 17). However, Peeters (1988, p. 404) rejects the description of this legislation as deregulation, instead describing it as "a perfect example of re-regulation." Minor acts of deregulation continued to reduce the nature and scope of the regulation of financial institutions through to the new century (Gowland, 2003, p. 272). However, a significant amount of ongoing uncertainty existed regarding the regulatory environment, particularly with the creation of the Financial Services Authority ("the FSA"), which acquired responsibilities for prudential supervision from the Bank of England in 1997. Gowland (2003, p. 272) states that this uncertainty meant the banking system never reached a "liberal model" of regulation. 
Consistent with uncertainty diminishing the pro-competitive impact of deregulatory reforms, Matthews, Murinde and Zhao (2007) analyse data for 12 banks for the period 1980-2004 and find that "the intensity of competition in the core market for bank lending remained approximately unchanged throughout the 1980s and 1990s". Studying the industry in a report published in 2000, Don Cruickshank found evidence of continued competition problems in the UK's banking industry (para. 1.7):

The Review concluded that the special treatment of banks goes further than the risks of the banking business require, and that the most likely explanation lies in the existence of an informal contract between successive governments and banks, designed to deliver public confidence in the banking system, but in practice straying well beyond the policies required to achieve that vital objective. In return for cooperating in the delivery of this objective, the banking industry has been allowed to escape the rigours of effective competition. Thus in developing policy government tended to negotiate with the larger banks, rather than set up incentives on them and others to deliver particular outcomes.

Cruickshank identifies (paras. 2.16-2.32) a number of significant barriers to entry, efficiency and innovation created by, he suggests, this contract. He argues barriers to entrants come from: ${ }^{53}$

- $\quad$ the FSA informally requiring new entrants to be linked with an established bank

- $\quad$ the FSA informally requiring that banks not be owned by a non-banking parent

- $\quad$ the FSA's criteria for authorisation of new banks not being transparent

- $\quad$ the FSA requiring higher capital asset ratios of new entrants than of established players

- $\quad$ inconsistencies in the application of the UK's Value Added Tax (VAT) that make outsourcing of banking services a less attractive option, creating a barrier for smaller banks

53 The Bank of England Act 1998 had, by that time, formerly transferred supervisory responsibilities from the Bank of England to the FSA. 
- $\quad$ overly prescriptive regulatory rules, including anti-money laundering rules, which favour established banks.

If the publication of the Cruickshank Report represented an opportunity for the nature of the regulatory contract to be changed, it appears to have been missed. Le Fanu (2004) notes that the UK Government remained wedded to holding the banks to its informal contract, by having banks function as an arm of government by helping to deliver government policies - Le Fanu notes (p. 154) the role of banks in providing training for small and medium sized businesses as an example of this.

\subsubsection{Payment System Development Following the Reforms}

\section{Debit cards and EFTPOS UK}

In spring 1985, serious, collective attempts started to develop national EFTPOS technology (Rob Walker, former Manager, Business Services, EFTPOS UK Limited, 2010, May 20, personal communication). Following a 1986 report from the EFTPOS strategy review committee, the banks agreed on a strategy for such a network, creating EFTPOS Administration Ltd in 1987 to be run by APACS (Howells and Hine, 1991, p. 398). The company eventually became EFTPOS UK Limited (EFTPOS UK) and it began work on a national approach to debit cards called the Unified Debit Card Scheme (UDCS).

The review process that preceded the creation of EFTPOS UK appeared overly slow to a number of banks, leading them to create their own EFTPOS trials, independent of the national network. ${ }^{54}$ Howells and Hine (1993, pp. 25-26) argue that one impetus for the banks' trials came from Cresta Communications' 1984 EFTPOS experiment in London. Cresta, whose offline system proved popular with retailers, was owned by British 
Telecom, who also became involved with EFTPOS UK and eventually discontinued development of its separate system. Bank trials included the Pretty Damn Quick (PDQ) terminal launched commercially by Barclays Bank for credit card transactions in 1986. PDQ operated using the DES encryption algorithm, which, at that time, was not thought to be compatible with an alternative algorithm, RSA (Howells and Hine, 1993, p. 404).

In 1986, as the industry moved towards a national network, Barclays threatened to withdraw unless EFTPOS UK adopted a DES encryption algorithm thereby making the UDCD compatible with Barclays' PDQ terminals (Howells and Hine, 1993, p. 404). EFTPOS UK eventually chose to use a RSA algorithm, in spite of the PDQ receiving substantially more use, internationally (ibid, pp. 187-188). Before this happened, however, Barclays announced, in October 1986 it was launching a Visa debit card, Connect, adding debit card functionality to its PDQ terminals, and launching Connect in April 1987 (Monopolies and Mergers Commission, 1989, para. 2.79). ${ }^{55}$ The announcement represented a substantial departure from the national approach, which had been working towards the UDCS and caused other banks to follow suit and introduce their own networks - another major UK bank, Lloyds, announced it was following Barclays by introducing a Visa debit card, while three other EFTPOS UK members announced their agreement to introduce the Switch debit card network in $1988 .^{56}$

Given the development of other debit card networks occurring in parallel with UDCS development, Howells and Hine (1993, p. 124) pose the question, "why did EFTPOS UK Ltd continue as an ongoing project after 1987?" They suggest that the member banks stayed involved to influence outcomes, to avoid providing an opportunity for one

\footnotetext{
55 In spite of launching a competing card, Barclays remained a member of EFTPOS UK.

56 These debit cards functioned using signatures. The development of online debit cards, which functioned using PINs, did not occur until 1997, as I discuss below.
} 
bank's competitors to unite against its interests and to be seen to conform to the interests of the industry. This latter role is important because the British central bank, the Bank of England, held a seat on the board of EFTPOS UK Ltd and Howells and Hine argue (p. 115), it had a strong preference for a co-operative national network to maintain public confidence in the banking system. They quote one bank manager as saying (p. 114):

There's no way somebody like Barclays could stay out of that [EFTPOS UK], even if they wished to stay out of it. I think there would have been a lot of arm-twisting at governmental level, if you like, to persuade a major bank to participate in the new clearing system.

Another is quoted (pp. 114-115):

Now, I don't think it's accidental, and this is a personal view, that someone from the Bank of England was brought in to try and knock heads together and to try and find a way forward.

In January 1990, APACS announced the success of the first EFTPOS UK trial, known as the Business Inaugural Service, but also, in spite of this success, its early wind-up (Howells and Hine, 1993, p. 134). This left competition over the provision of debit card services to the Switch and Visa debit card brands.

\section{Further ATM and debit card developments}

During this time, building societies and banks continued to build on the ATM network, LINK. LINK acquired other shared ATM networks and, during the early 1990s, gradually supplanted the practice of banks signing interbank sharing agreements to allow customers to use another bank's ATMs (Bátiz-Lazo, 2009, p. 18). According to Bátiz-Lazo, such agreements proved cumbersome to manage and gave banks only a limited ability to increase the scale of their ATM networks, making membershipof the LINK payment network an attractive proposition. 
Pricing principles in the UK appear to be more limited than in my other sample countries. I have not found any background to its existence, but Milne (2007, p. 66) says that, "... while there is no legal restriction, the convention of 'free in credit banking' is well established (this is the convention that personal bank customers should not be charged for payments services provided their accounts remain in credit or within agreed overdraft limits)." Being unable to charge customers for debit cards implies a need to charge merchants. Barclays initially encountered difficulty promoting its Connect card to merchants when it proposed charging them proportional fees for acquiring Connect transactions, as happened for Visa credit card transactions (Howells and Hine, 1993, pp. 70-73). However, merchants rebelled, identifying debit cards as a replacement for cheques, which incurred fixed per-transaction fees. A number of retailers went as far as to flagrantly break Visa's Honour-All-Cards Rule by accepting Visa credit cards, but not debit cards. In December 1987, however, Barclays backed down and agreed to charge a fixed fee for most transactions. While Visa set fixed interchange fees to be used between its members for all debit card transactions, Switch negotiated interchange fees bilaterally, which, in the early 1990s, were rumoured to be zero, causing Switch transactions to incur significantly lower MSFs than Visa transactions (Howells and Hine, 1993, p. 80). MSFs remained significant for debit cards in the UK; Van Hove (2007, p. 8) who, citing the magazine, Cards Technology, refers to debit card transactions as having a price of 10 pence or less per transaction for large retailers to 19 pence for small ones. ${ }^{57}$ In addition to paying MSFs, merchants are generally required to buy or rent debit card terminals in the UK (Rob Walker, former Manager, Business Services, EFTPOS UK Limited, 2010, September 14, personal communication).

57 Further evidence comes from Worthington and Harbisher (1997, p. 269); they identify that debit card payments cost large corporate merchants only a few pence, but cost some small independent retailers anything up to $80 \mathrm{p}$. 
The aggressive competition from the Switch debit card brand caused Barclays Bank, a Visa debit card issuer, to take Switch to the Office of Fair Trading in early 1990 because it objected to the Switch rule that any member issue a Switch debit card as its main debit card (Howells and Hine, 1993, pp. 55-56). This rule prevented Barclays Bank from acquiring Switch transactions and, according to Howells and Hine, the Office of Fair Trading threatened to refer Switch to the Restrictive Trade Practices Court, resulting in Switch dropping the rule. Barclays Bank was subsequently allowed to become a member of Switch, as an acquirer and issue Switch cards as well as its Visa Connect card.

A Monopolies and Mergers Commission report (1989) (discussed below) commented (para. 2.87) on a complaint from the food supermarket operator, Sainsbury, that it wanted to accept Visa's debit cards but not its credit cards, but could not do so because of the Honour-All-Cards Rule. Shortly after the report's August publication, Visa and Barclays Bank launched the Visa Electron card, allowing merchants to accept it, but not Visa's credit cards, thereby allowing them to increase Visa Electron's acceptance and compete more effectively with the Switch debit card, which did not suffer from such constraints (Barchard, 1989, November 4).

During the 1990s, both debit card networks introduced online, PIN-based networks; Switch with the 1997 launch of the Solo card and Visa with a second launch in 1997 of the Electron card (Rob Walker, former Manager, Business Services, EFTPOS UK, 2010, May 20, personal communication). ${ }^{58}$ The Switch debit card was eventually merged into the MasterCard brand, while the Solo card remained a distinct brand. At the time the change occurred, the network shifted from bilateral inter-bank agreements to one multilateral, hub-and-spoke agreement (Office of Fair Trading, 2003, p. 119). 


\section{Chip and PIN}

In 1994, concerns about fraud meant APACS members formed the Integrated Chip Card (ICC) project to provide an infrastructure to replace all magnetic strip based debit, credit and ATM cards with chip-based cards (Rob Walker, former Manager, Business Services, EFTPOS UK Limited, 2010, May 20, personal communication; Böhle, Rader and Riehm, 1999, p. 39). In 1993, the card schemes, MasterCard International, Europay International and Visa International, began co--operating in a working group on smart payment cards with their standard, which become known as EMV, first being released in 1994 (Birch, 1999, p. 1). In the UK, initial trials of this technology commenced in 1997 and were seen as successful with a national rollout begun in 1998 (Keycorp Limited, 2006, pp. 2-3). However, the trials and subsequent rollout continued to use signatures for cardholder verification, contributing to delays at the POS that reduced retailer support for the technology. Indeed, Birch $(1999$, p. 3) notes that the British Retail Consortium, which covered approximately $90 \%$ of the retail sector, effectively boycotted the roll-out and its members refused to be involved. During 2002, the banking and retail industries reached an agreement to proceed with technology that used the EMV chip standard with PINs to verify cardholders - technology called Chip and PIN (Keycorp Limited, 2006, p. 3). APACS performed a trial of Chip and PIN, its second of EMV technology, once again in Northampton in 2003. The trial was judged successful and the national roll out of the technology began later that year. ${ }^{59}$

I have not found evidence showing that the roll out of Chip and PIN involved substantial modifications to debit card MSFs in the UK. There was some complaint from merchants that there was no business case for Chip and PIN, which is understood

\footnotetext{
59 From the beginning of 2005, liability for fraudulent Chip and PIN card transactions at merchant not using a Chip and PIN terminal lay with the acquirer or, depending on the its contract with the acquirer, the merchant itself (Office of Fair Trading, 2005, p. 118).
} 
to have led to a "relatively small" plan to provide merchants with incentives to upgrade merchant-owned terminals (Rob Walker, former Manager, Business Services, EFTPOS UK Limited, 2010, September 14, personal communication).

The ATM network, LINK, gradually increased in size with a number of major banks joining during the late 1990s (Bátiz-Lazo, 2009, pp. 19-20). One bank, Barclays, attempted to introduce charges for ATM transactions, but the move attracted such comment from the media and other members of LINK that it was subsequently abandoned, restoring LINK's “free to use", single national ATM network status. By 2007, all banks and building societies were members of LINK (Milne, 2007, p. 71).

\section{Stored-value cards and London's Oyster card}

Ives and Earl (1997) describe the initial development in the UK of the Mondex storedvalue system. The first major trial of the Mondex instrument occurred in Swindon in 1995. Mondex was licensed internationally from around that time with Mondex International Limited, headquartered in London, established in 1996 to act as a franchisor. MasterCard purchased 51\% of Mondex in 1996. However, the Mondex system was not seen as a successful and later offered as a reason why banks would only wish to roll out a new instrument incrementally (MVAConsultancy, 2008, p. 4.5)

Bamodu (2003) summarises the regulatory framework introduced in the UK, consisting principally of the Financial Services and Markets Act 2000, in response to the European Union's Electronic Money Directive (2000/46/EC). The framework introduced a regulatory and supervisory framework for an electronic money institution, an issuer of electronic money, to be administered by the FSA. In 2003, Transport for London ("TfL") developed the Oyster card, a contactless card for use on London's Underground mass transit system. According to The Evaluation Partnership (2006, p. 27), TfL argued 
that the electronic money framework did not apply to it because of its structure, an argument that was accepted by the responsible regulatory authority, the FSA. ${ }^{60}$ By the middle of 2009, more than 6 million Oyster cards were in regular use (Transport for London, 2009, June 29). ${ }^{61}$ TfL had planned to extend Oyster to include an open e-purse usable for payments other than those relating to public transport, but TfL E-money Project Director, Will Judge, is quoted as saying that European Union regulations governing electronic money made it too expensive to go down that route (MVAConsultancy, 2008, April, p. 2.7). Instead, TfL partnered with Barclays Bank, in 2007, to launch a combined Oyster card with contactless credit card functionality (Kauffman, Li and van Heck, 2010, p. 6). In 2008, TfL partnered with a number of other organisations to trial what was dubbed, the "Oyster Phone" with which users could pay transit fares and make retail purchases by tapping their phones on readers (Balaban, 2008, November 1). The trial was judged a success: nearly eight out of 10 trial participants saying, if it was accepted, they would use the devices for payment; some participants reported to have "begged" to keep their phones after the six-month trial. However, in spite of this encouragement, Balaban says that a roll-out was not forecast until 2010 and might even take longer than that. I have been unable to find information suggesting further development of the Oyster phone.

\subsubsection{Interventions in Retail Payment Systems}

\section{UK regulation of network rules and interchange fees}

Government authorities in the UK have shown a long history in the operation of retail payment systems. Allowing merchants to surcharge credit card transactions was

\footnotetext{
60 Specifically, TfL argued that it bought services from the different providers and then resold them to passengers.

61 This is relative to a population of over 7.5 million residents in Greater London in July 2005 (Office for National Statistics, 2007, June 22).
} 
recommended by a 1980 Monopolies and Mergers Commission report (para. 11.106(d)). However, the UK Government decided against following the recommendation, "mainly because customers were likely to be inconvenienced or confused, and the display of information on surcharges would impose undue burdens on traders and be difficult to enforce" (Monopolies and Mergers Commission, 1989, para. 2.5). The Monopolies and Mergers Commission's 1989 report also found (para. 7.96) the rule “operates against the public interest because it restricts the freedom of retailers to set their own prices." It also noted (para. 7.95) that concerns about confusion were exaggerated "because they underestimate the ability of consumers... to look effectively after their own interests." This time, the Government agreed with the recommendation, passing the Credit Card (Price Discrimination) Order 1990 to remove the No-Surcharge Rule from credit cards in early 1991 (The implications of Credit Card Order 1990, 1991, March 9). I have found little evidence of the extent of surcharging for credit cards in the UK, although, in early 2011, a complaint was made to the UK regulator, the Office of Fair Trading, about surcharges that were higher than MSFs by the consumer group, Which? (Credit and debit card surcharges 'are excessive', 2011, February 11).

The Monopolies and Mergers Commission (1989, paras. 2.82-2.95) also considered the Honour-All-Cards rule in relation to the fees charged by Barclays Bank during its 1987 launch of the Visa-badged Connect debit card and a complaint about the Honour-AllCards Rule made by Sainsbury's (both described in the previous sub-section). The Commission saw the conduct as an attempt by Visa issuers to exploit their market power for Visa credit cards when introducing debit cards. However, the report also said (paras. 7.101-7.102) that the Honour-All-Cards Rule was beneficial for cardholders and that it increased the ability for issuers to offer new card products. Accordingly, the report did not recommend the abolition of the Honour-All-Cards Rule, but that the 
Director General of Fair Trading would "no doubt be alert for any further instances of its abuse."

Authorities have also shown an interest in interchange fees: without giving details of the nature of its investigation, Tseng (n.d.) uses information relating to interchange fees from an Office of Fair Trading (the "OFT”) report published in 1994. I have not, however, found any evidence on OFT interchange fee investigations until 2000, when MasterCard applied for its interchange agreements to be granted an exemption to the Competition Act 1998, which came into effect that year (Colomer 2006, February 13). In response to MasterCard's application, the British Retail Consortium filed a complaint with the OFT, causing the authority to also investigate Visa, which had not submitted its agreements, voluntarily (Lee, 2003, February 12; UK interchange ruling is threat to credit cards worldwide, 2003, February 28).In September 2005, the OFT released a decision (2005a) that concluded that the MasterCard Multilateral Interchange Fee infringed the Competition Act 1998 and European Union competition law. However, MasterCard appealed the finding, leading to the decision being set aside by the Competition Appeals Tribunal in June 2006. The OFT started a second investigation, conducting it in parallel with its investigations of interchange fees for Visa; both are ongoing (Barclays Bank, 2010, August 6). In February 2007, the OFT announced that it was expanding its investigation into interchange rates to include debit cards. In September 2007, MasterCard abandoned a plan to introduce proportional charges for debit card transactions (UK retailers breathe sigh of relief, 2007, September 25).

\section{Direct entry payment networks}

Government concerns about the competitiveness of the banking industry led to a review of competition in banking services, named the Cruickshank review, after the inquiry chairman, Don Cruickshank. The review reported in March 2000, identifying concerns 
about price competition and innovation in the provision of payment services that required public policy intervention. It recommended modifications to the governance structure of organisations involved in payments in the UK and proposed the creation of a payments regulator with legal powers to intervene in payments provision. Milne (2007, p. 69) reports this proposal was successfully resisted by the banking industry, but the review did lead to the creation, announced by the Government in 2003, of the Payments System Task Force, to be headed by the competition regulator, the Office of Fair Trading. ${ }^{62}$

The Cruickshank review's concerns about payment network innovation are analysed in a paper by Ganguly and Milne (2002). They agree with the nature of the concerns, but suggest they are caused by poor incentives to invest in payment system innovations. Ganguly and Milne base analysis of these poor incentives on the unsupported assertion (made on p. 155) that, effectively, innovations are non-excludable. The nonexcludability of innovations is implied by other researchers: the Office of Fair Trading (2003, para. 1.42) says “... reflected some of the disincentives arising from the need to cooperate and the interdependency of decisions on investment." Milne (2007, pp. 6465) says that, “... innovation in shared bank-to-bank payments systems is held back because no individual bank can gain any competitive advantage from improvements in these shared payments arrangements." However, I have been unable to document the reasons for the implied non-excludability of direct entry payment innovations in the UK and the issue, as well as the ultimate cause of the lack of direct entry payment innovations, remains an avenue for further research.

62 In 2006, a recommendation of the Taskforce led to the creation of a successor body, the Payments Council, which has a 15 member board of directors comprising 11 representatives of the banking industry and four independents. 
Whatever the cause, though, such innovation remained problematic: in 2002, BACS initiated technological renewal programme known as NewBACS, although significant uncertainty existed around the exact functionality of the new system (Office of Fair Trading, 2003, paras. 8.3, 9.140). Although it required some intervention by the UK Government to achieve it, greater certainty existed around the creation of a network separate from BACS, the Faster Payments Service (Bank of England, 2009). In 2004, the Payments System Task Force commissioned a working group to complete a report considering innovation in direct payments. The working group reported the following year and recommended that modifications be made to increase the speed with which interbank transactions were processed (Office of Fair Trading, 2005b, p. 4). In 2005, APACS awarded a contract to provide such a network called the Faster Payments Service. Senechal (2010) describes how the service went beyond the Task Force's initial expectations to create a system suitable for a broad number of retail payments, including those made using the internet or mobile phones.

During 2004, following an investigation of the supply of store card credit to consumers and of store card services to retailers, the Office of Fair Trading found the industry lacked transparency with the interest rate on credit given to consumers being 10 percentage point higher, on average, than the average charged by credit cards. The Office of Fair Trading referred the industry to the Competition Commission for further investigation. Following its own investigation, the Competition Commission ordered changes to the industry, including that pertinent information, such as applicable interest rates, be displayed on customers' store card statements and that customers be given the easy ability to repay outstanding balances by direct debit. 


\subsubsection{Data Showing Payment Instrument Adoption in the United Kingdom}

To show adoption of debit and credit cards in the UK, I use debit card and credit card transaction data with population data from the Redbook publication, CPSS (2009) supplemented with data for 2000-2003 from the earlier Redbook, CPSS (2006). In the data I user for credit card transactions, I include transactions completed with delayed debit cards. Data discrepancies existing between different CPSS publications mean that I source data from the Redbook, CPSS (2008) for the years 2002 and 2003. As a check on my use of the CPSS data, I use statistics from a UK Cards Association document, UK Payments Administration Limited, 2009, p. 2. It provides a statistical release showing debit and credit card payment volumes from 2003 to 2008. Importantly, the data show acquired transactions, in contrast to the CPSS Redbook data showing issued transactions. In spite of the difference, the data compare well, with the Association's data all being within 5.6\% (averaging $-2.5 \%$ ) of the CPSS figures.

\subsubsection{Bibliography for Summaries of the United Kingdom}

Ashton, J. K. and Boyes, G. (2002, September). Cruickshank's recommendations as to the future of the UK payment system. Journal of financial regulation and compliance, 10(3), 209-218

Bamodu, G. (2003). The regulation of electronic money institutions in the United Kingdom. Journal of information, law and technology, 2, Retrieved from http://www2.warwick.ac.uk/fac/soc/law/elj/jilt/2003_2/bamodu

Bank of England. (2009). Payment systems oversight report 2008, Retrieved from http://www.bankofengland.co.uk/publications/psor/psor2008.pdf

Barclays Bank. (2010, August 6). Barclays Bank PLC half yearly report. Regulatory news service

Balaban, D. (2008, November 1). Mobile revenue trickles in. Cards \& Payments, 21(11)

Barchard, D. (1989, November 4). Visa alters rules for debit card. Financial times, p. 5

Bátiz-Lazo, B. (2009). Emergence and evolution of ATM networks in the UK, 19672000. Business history, 51(1), 1 - 27

Bátiz-Lazo, B. and Wood, D. (2002). An historical appraisal of information technology in commercial banking. Electronic markets, 12(3), 192-205 
Birch, D. (1999, June 26, reprinted). The ABC of EMV. Financial times virtual finance report, Retrieved from www.dgwbirch.com/papers/ftvfr/028emv406.pdf

Böhle, K. Rader, M, and Riehm, U. (1999). Electronic payment systems in European countries - country synthesis report, final report, Brussels: European Commission. Retrieved from http://www.elektronischesgeld.de/organisationen/ESTOCSRfina1991216.pdf

Colomer, N. (2006, February 13). MasterCard facing new investigation in U.K. regarding interchange fees. Asset securitization report

Cheque and Credit Clearing Company Limited. (n.d.). History of the cheque: The emergence of technology, Retrieved on 14 March 2010 from http://www.chequeandcredit.co.uk/information/-/page/history_of_the_cheque/

Committee on Payment and Settlement Systems [CPSS]. (2006). Statistics on payment and settlement systems in selected countries. Prepared by the Committee on Payment and Settlement Systems of the Group of Ten Countries, Publications No. 74, Retrieved from http://www.bis.org/publ/cpss74.htm

Committee on Payment and Settlement Systems [CPSS]. (2008). Statistics on payment and settlement systems in selected countries. Prepared by the Committee on Payment and Settlement Systems of the Group of Ten Countries, Publications No. 82, Retrieved from http://www.bis.org/publ/cpss82.htm

Committee on Payment and Settlement Systems [CPSS]. (2009). Statistics on payment and settlement systems in selected countries. Prepared by the Committee on Payment and Settlement Systems of the Group of Ten Countries, Publications No. 88, Retrieved from http://www.bis.org/publ/cpss88.htm

Credit and debit card surcharges 'are excessive'. (2011, February 11). BBC business news, Retrieved from http://www.bbc.co.uk/news/business-12423004

Cruickshank, D. (2000, March). Competition in UK Banking: A report to the Chancellor of the Exchequer, Norwich: Her Majesty's Stationery Office, Retrieved from http://www.hm-treasury.gov.uk/fin_bank_review.htm

Duggan, S. and Karpinski, J. (1988, April/May). The money transmission system, competition and the banks, Economic affairs, 8(4), 35 - 44

Ganguly, B. and Milne, A. (2002). Retail payment systems in the UK: is there a lack of competition?, published in Pringle, R. \& Robinson, M, (eds) E-money and payment systems review, Central Banking Publications

Gowland, D. (2003). Financial reform in the UK. In Hall, M. J.B. (Ed.), The international handbook on financial reform, 249-275. Cheltenham: Edward Elgar Publishing Limited.

Howells, J. and Hine, J. (1991). Competitive strategy and the implementation of a new network technology: the case of EFTPOS in the UK. Technology analysis \& strategic management, 3(4), 397-425 
Howells, J. and Hine, J. (eds) (1993). Innovative banking: Competition and the management of new networks technology, London: Routlege

Ives, B. and Earl, M. (1997). Mondex International: Reengineering money, London Business School CRIM CS97/2, Retrieved on March 5, 2011 from http://wings.buffalo.edu/academic/department/som/isinterface/is_syllabus/mondex/mon dex.html

Kauffman, R. J., Li, T. and van Heck, E. (2010). A theory of informedness and business network co-production. Proceedings of the 43rd Hawaii International Conference on System Sciences, Retrieved from http://www.computer.org/portal/web/csdl/doi/10.1109/HICSS.2010.39

Keycorp Limited. (2006). MULTOS white paper: Lessons in EMV migration, Retrieved from http://enca.keycorp.net/NR/rdonlyres/D2F98924-9E53-4C6A-AC210EA44A9D762E/0/EMVWhitePaperforCartes.pdf

Klein, G. and Lambert, J. (1987). The business of banking, London: Methuen \& Co. Ltd Le Fanu, J. (2004). The UK banking market: Consolidation, competition and the Cruickshank Report. Die Bank, 3/2004, 150-154

Lee, W. (2003, February 12). Interchange rate battle now spreading to U.K. American Banker

Matthews, K., Murinde, V. and Zhao, T. (2007). Competitive conditions among the major British banks, Journal of banking \& finance, 31, pp. 2025-2042

Milne, A. (2007). Governance and innovation in UK retail payments. Communications \& strategies, 66, 63-77

Monopolies and Mergers Commission. (1980, September). Credit card franchise services: A report on the supply of credit card franchise services in the United Kingdom, Cmnd. 8034, London: Her Majesty's Stationary Office

Monopolies and Mergers Commission. (1989, August). Credit card services: A report on the supply of credit card services in the United Kingdom, London: Her Majesty's Stationary Office, Retrieved from http://www.competitioncommission.org.uk/rep_pub/reports/1989/255creditcard.htm

MVAConsultancy. (2008, April). E-money review: Final report for Department for Transport, In association with Alco and Osborne Clark, London: Her Majesty's Stationery Office, Retrieved from http://www.dft.gov.uk/pgr/scienceresearch/orresearch/emoney.pdf

Office for National Statistics. (2007, June 22). Population and migration of Greater London, Retrieved on 2010, July 25 from http://www.statistics.gov.uk/cci/nugget.asp?id=1812

Office of Fair Trading. (2003). UK payment systems: An OFT market study of clearing systems and review of plastic card networks, OFT658 
Office of Fair Trading. (2005a). Investigation of the multilateral interchange fees provided for in the UK domestic rules of Mastercard UK Members Forum Limited, Decision No. CA98/05/05

Office of Fair Trading. (2005b). First annual progress report of the Payment Systems Task Force, report prepared for the Payment Systems Task Force, OFT789a

Organisation of Economic Cooperation and Development [OECD]. (2007). Competition and efficient usage of payment cards, DAF/COMP(2006) 32

Peeters, J. (1988). U.K. financial services re-regulation. University of Pennsylvania journal of international business law, 10(3), 371-407

Retail Banking Research Ltd. (2005). Regulation 2560/2001: Study of competition for cross-border payment services. Final report, Project $\mathrm{N}^{\circ}$ Markt/2004/11/F, Retrieved from http://ec.europa.eu/internal_market/payments/docs/reg-20012560/competition_en.pdf

Rollason, R. (1989). Managing money transfer, or paying less on paying out, Managerial auditing journal, 4(1), 11-16

Schooner, H. M. and Taylor, M. (1999, Summer). Convergence and competition: the case of bank regulation in Britain and the United States. Michigan journal of international law, 20, 595-655

Senechal, N. (2010). UK Faster Payments: Universal wave of the future or a distinctive UK payments model? Journal of payments strategy and systems, 3(4), 320-332

The Evaluation Partnership. (2006). Evaluation of the E-Money Directive (2000/46/EC), Final Report. Retrieved from:

http://ec.europa.eu/dgs/internal_market/docs/evaluation/e_money_directive.pdf

The implications of Credit Card Order 1990. (1991, March 9). Financial times

Transport for London. (2009, June 29). First train operating company outside London to sell visitor Oyster cards. Retrieved on 2010, July 25 from http://www.tfl.gov.uk/corporate/media/newscentre/archive/12142.aspx

Tseng, J. (n.d.). What's SMART about credit card payments? Erasmus University Rotterdam, Retrieved on March 6, 2011 from http://www.imamu.edu.sa/DContent/IT_Topics/WhatsSMART.doc

UK interchange ruling is threat to credit cards worldwide. (2003, February 28). Retail banker international

UK Cards Association. (2009). Spending in the UK on debit and credit cards: Third quarter statistical release, Retrieved from

http://www.theukcardsassociation.org.uk/files/statistical_release_2009_q3,_30_novemb er.pdf

UK Payments Administration. (n.d.). CHAPS Co, Retrieved on 2010, November 21 from http://www.ukpayments.org.uk/uk_payment_schemes/chaps_clearing_company/ 
UK retailers breathe sigh of relief, (2007, September 25). Electronic Payments International

Van Hove, L. (2007). SEPA \& debit-card interchange fees: One size fits none? E-money \& e-trading development (SPEED), 2(2)

Worthington, S. and Harbisher, A. (1997). Case study: Retailers and their relationships with their financial services suppliers: the case of debit card charges in the United Kingdom. Journal of retailing and consumer services, 4(4), 269-274 


\subsection{United States}

\subsubsection{Retail Payment Systems and Government Controls on Banking}

Schooner and Taylor (1999) give a chronology of the US banking system since the American Civil War, a chronology involving numerous interventions by state and federal governments. They summarise (pp. 609-613) legislative actions that created a dual-banking system in the nineteenth century, involving federally-chartered banks alongside state-chartered ones. Kane (1996, pp. 142-143) says that, beginning late in the nineteenth century, state governments introduced statutory barriers limiting the branching of state-chartered banks. ${ }^{63}$ Quoting the work of Golembe, Kane describes (p. 143) the motivation behind branching restrictions: "[a]lthough sponsors of branchbanking statutes used the rhetoric of protecting customers against exploitation by regional and national money trusts, the lobbying force behind branching restrictions is widely acknowledged to be the preservation of local monopolies or oligopolies for community banks." A large number of interventions were made around the time of the Great Depression. These included the creation of a federal deposit insurance scheme, the regulation of interest rates offered by US banks that and the separation of firms that offered commercial banking services from those offering investment banking. Schooner and Taylor attribute (p. 651) the structure of US banking regulation put in place during the Great Depression to "a powerful current of domestic politics" involving a deep-seated suspicion of money and of large financial institutions. They also say (pp. 651-652) that "difficulties the US has encountered in dismantling this system of constraints on banking is testament to the continued political appeal of this

\footnotetext{
63 Restrictions on federally-chartered banks eventually developed to complement state restrictions with Banking Act of 1933 giving them the right to branch as state-chartered banks did (Kane, 1996, p. 143).
} 
ideology as well as to the strength of the domestic interests that benefit from the limitations on competition it creates."

In addition to regulations covering banking activity, another major influence on retail payment system development was the role of the central bank, the Federal Reserve, in the processing of cheques. ${ }^{64}$ The Federal Reserve Act, passed in 1913, created a regulatory system that was compulsory for federally-chartered banks and optional for state-chartered banks (Berle, 1949 p. 594). ${ }^{65}$ It also required the Federal Reserve establish a cheque-clearing system with its regional banks acting as cheque clearinghouses (Baxter, 1983, p. 567). Baxter argues that the Federal Reserve used a mixture of subsidies and coercion to encourage banks to use its system and redeem cheques "at par" (without transaction fees). It was able to price cheque-clearing services in this way for member and non-member banks alike because it did not pay interest on the substantial reserves required to be deposited by members as part of its regulatory system (Baxter, 1983, p. 567). ${ }^{66}$ This pricing made it more difficult for alternative clearinghouses to compete for Federal Reserve members' and non-members' cheque-clearing business.

\section{The development of credit cards}

A major development for retail payment systems came in 1949 with the large-scale, national introduction of a payment card, the Diners Club card, that could be used by cardholders at many different retailers (Stearns, 2007, p. 36). This type of card became known as a travel and entertainment, or T\&E, card because it was principally used for

\footnotetext{
64 The word, cheque, is spelt, check, in the U.S. I adopt the spelling used in New Zealand in this thesis.

65 Berle notes that banks were given "powerful inducements" to become members, but a substantial number remained non-members.

66 It was not until after legislative reform in 1980 that Federal Reserve Banks were required to recover the costs of providing services to member banks (Cavalluzzo, Ittner and Larcker, 1998, p. 2).
} 
the payment of restaurant, hotel, airline and other business-related expenses. In order to generate profit, Diners Club charged merchants an MSF by only paying them a discounted amount of the invoice, commonly six or seven percent less, much as had occurred for cheques prior to government interventions in the American cheque-clearing industry (Stearns, 2007, p. 36). The card grew quickly, gaining over 100,000 cardholders in just its first year, and expanded into Europe using franchise agreements in the mid-1950s (Stearns, 2007, pp. 38-39).

As it expanded, Diners Club experienced strong resistance to its practice of charging MSFs by discounting the amount of invoices from some groups of merchants, particularly those in the hotel, oil and airline industries (Mandell, 1990, pp. 26-27). Some American and European hotel trade associations threw out members who accepted cards that had charged MSFs by discounting invoices, while British and Swedish hotels established their own card, the BHR card (which eventually became the EuroCard) and the American Hotel Trade Association introduced the Universal Travel Card. Neither proved successful. In fact, the Eurocard, which initially operated with only cardholder charges, was forced to introduce an MSF to improve its profitability (ibid, p. 27).

The Universal Travel Card was one of a number of store cards in the US, accepted at only a single chain of stores or by a group of retail stores in the same industry. Although they have recently become less used by consumers, store cards have been a vibrant part of retail payment systems market in the US. ${ }^{67}$ Stearns (2007, pp. 38-39) summarises retailers' initial resistance to general use cards, in preference to their own store cards. In fact, Stearns reports that the American Hotel Trade Association 
prohibited members from accepting some general use cards. Durkin (2000, p. 624) reports that, in the early 1970s, store cards were much more widely held than generaluse credit cards, but that peaked in approximately 1990 and, by 1995, general-use cards had become more common. Store cards also represent an avenue for entry to the T\&E card (travel and entertainment card) industry, as demonstrated by the US department store chain, Sears Roebuck \& Co. when it launched the Discover Card in 1985, "capitalizing on its tremendously successful store card" (Chang, 2004, p. 36). Diners Club operated in the T\&E card industry with little competition until travellers cheque issuer, American Express, and Carte Blanche, formerly a store card owned by Hilton Hotel Corporation, entered in 1958 (Stearns, 2007, pp. 40-41). The increased competition led to greater use of computers for bookkeeping and billing and the introduction of gold cards for the most credit-worthy cardholders (Stearns, 2007, pp. 4042).

Competition also came from banks. From 1947, slightly before the introduction of the Diners Club card, over 100 banks experimented with introducing credit or charge cards, but most failed to become profitable, partly because banking regulations prevented card networks reaching sufficient size (Stearns, 2007, p. 43). ${ }^{68}$ In 1958, Bank of America introduced the BankAmericard to locations in California. Stearns (2007, pp. 43-44) suggests this bank was ideally suited to creating a payment card because it operated in California, which allowed state-wide bank branching, giving the company a larger market for its card, and because it already offered consumer loans, unlike many other banks at that time. Although banks tried similar systems following Bank of America's lead, many proved unsuccessful (Stearns, 2007, p. 48). However, the second half of the 1960s saw a sudden increase in the number of banks offering credit cards, a 
development that Stearns (2007, pp. 48-49, referring to the work of Frederick Struble), attributes to the sudden increase in computing power experienced at that time and more importantly to the creation of national bankcard associations.

Stearns $(2007$, p.4, 49) argues that associations were developed to create a national network of credit cards while getting around regulations preventing inter-state banking. Bank of America licensed its card to other banks to issue from $1966 .{ }^{69}$ To compete with the BankAmericard and its licensees, other banks formed regional, non-profit cooperative associations with their card programmes and joined them together to form the Interbank Card Association in 1966, which become MasterCard in 1979 (Evans and Schmalensee, 2005a, p. 66). Initially, Bank of America's licence structure for BankAmericard was distinct from the associations and the BankAmericard remained effectively linked to Bank of America; this made other banks uncomfortable about issuing what was their competitor's card (Stearns, pp. 62-63; Evans and Schmalensee, p. 64). This remained an issue until the BankAmericard license structure was turned into a multi-party membership corporation, named National BankAmericard Inc (NBI), in 1970 (Evans and Schmalensee, 2005b, pp. 64-65; Stearns, 2007, pp. 68-80). ${ }^{70}$ The new NBI structure was akin to the Interbank structure and the change marked the end of use of licenses for credit cards in the US. National BankAmericard was renamed Visa in 1976 (Stearns, p. 130).

In order to prevent Interbank hearing of its plans for development, NBI introduced a bylaw preventing full members of its organisation from also issuing Interbank's cards, a practice that became known as "duality" (Stearns, 2007, pp. 123-125). One NBI

\footnotetext{
69 The card was also licensed for the first time internationally in 1966, to Barclay's Bank in the UK (Stearns, 2007, p. 50).

70 This organisation, and its international affiliate, IBANCO, adopted the name, Visa, in 1976 (Stearns, 2007, p. 130).
} 
member challenged the by-law, arguing that it was a horizontal restraint on trade. NBI responded that the by-law ensured greater inter-network competition and its removal would cause little incentive for members to break away to form a new competitor to NBI. The case went to several stages of trial, before NBI and its member settled out of court. NBI unsuccessfully sought clear guidance on the legality of its by-law from the US Department of Justice before eventually abandoning it and allowing duality in 1976 (Stearns, 2007, p. 126). ${ }^{71}$

As the two card systems expanded, Evans and Schmalensee (2005b, p. 83) describe efforts to deal with how to interchange transactions between merchants' and cardholders' banks. The BankAmericard network initially attempted to have the entire MSF passed over from the acquirer to the issuer. However, such an approach failed because, according to Evans and Schmalensee, it invited deception by acquirers and reduced the incentive to sign up merchants. In some cooperative networks, banks attempted to agree interchange fees bilaterally, which was possible when networks had few members, but proved very difficult for larger networks. NBI eventually introduced a standard interchange fee of $1.95 \%$ in 1971 (Stearns, 2007, p. 78) and, although without clarifying timing, Evans and Schmalensee (2005b, pp. 83) report that Interbank introduced a similar fee.

\section{Other developments in the US: Inter-bank funds transfers, ATMs and debit cards}

During the late 1960s, members of the US banking industry started considering the potential for technological solutions to the problem of reducing the number of cheque transactions (Bradford, 2007, p. 1; Electronic Payments Network, 2004, p. 1).

71 I purposefully leave aside the Supreme Court's 1979 decision in the case, Marquette National Bank v. First of Omaha Service Corp, because, while it was key to the operations of credit card networks, it is less relevant to credit cards' use as a payment instrument; the decision allowed credit cards to get around individual States usury laws by making issuers bound solely by the usury laws of the State in which they resided (Rosenburg, 2005). 
Electronic Payments Network (2004, p. 3) says that the first electronic interbank payment system to begin operation was the Clearing House Interbank Payments System, commonly known as CHIPS, which was used for wholesale interbank transactions from 1970. Associations of systems designed for retail payments soon followed, with many using Federal Reserve equipment and staff (Electronic Payments Network, 2004, p. 1). In 1974, five associations formed the National Automated Clearing House Association to coordinate ACH transfers nationwide and develop uniform rules and standard formats (Bradford, 2007, p. 1). By 1978, there were ACH associations covering the US operating under the standards established by the National Automated Clearing House Association (Electronic Payments Network, 2004, p. 1).

An ATM in the US was installed in Long Island, New York in 1969 (Hayashi, Sullivan and Weiner, 2003, p. 12). Networks of ATMs linked to central computers quickly developed, with some being shared between firms that were otherwise competitors. Hayashi et al (ibid, p. 14) report, however, that there was significant legal uncertainty about whether ATMs (at a later, this uncertainty also affected POS debit card terminals) represented bank branches and therefore faced ownership and location restrictions. In spite of this uncertainty, the number ATMs steadily increased from the early 1970s, reaching over 50,000 by 1985 (ibid, p. 18). Hayashi et al also report (pp.13-14) a number of other key developments involving ATMs:

- $\quad \mathrm{n} 1975$, a grocery store chain in Iowa installed ATM machines on its premises

- in 1976, another grocery store chain in Massachusetts installed a POS terminal the following year to allow payments to be made directly to it using cards such as those suitable for ATM transactions and

- $\quad$ in 1977, the first shared ATM network with an online connection to account information was developed. 
The development in the US of debit card transactions at the POS had begun sometime earlier than ATMs, with a series of pilot networks, the first of which was initiated by Bank of Delaware in 1966 (Caskey and Sellon, 1994, p. 82 and endnote 1). Caskey and Sellon report, however, that the pilots were used "almost exclusively in local pilot programs designed to gauge consumer and merchant acceptance" and I have not identified any substantial development of debit card networks occurring until later. Evans and Schmalensee (2008, p. 5) argue that the technology underlying today's debit card networks was not created until Visa introduced a POS terminal in 1979. Since they already connected ATM terminals with centralised computers, ATM networks were able to provide "online" debit card services to POS terminals with the balance debit card being checked automatically and immediately. The large number of ATM networks I described above, however, appeared to impede large scale POS debit card development: Caskey and Sellon (1994, pp. 85-86) report that the large number of ATM cards held by many merchants' customers meant merchants had to install many different terminals to accept debit card payments from them all. Similarly, Hayashi et al (2003, p. 14) report that the growth of debit cards was reduced by the existence of multiple technical standards governing their use. A major alternative debit card development was the "offline" card, which operated using procedures developed for credit card schemes, with customers' accounts being debited in the days following a transaction as occurred for credit card transactions. In 1975, Visa's predecessor organisation, NBI, launched the Entrée card, which was later renamed Visa Debit (Stearns, 2007, pp. 175-176). ${ }^{72}$

Stearns gives the Visa Debit case as one example of what led Visa's members to interpret Visa's actions as overstepping the role for which it had been created. The other example Stearns gives was Visa's 1979 deal with one of America's three largest

72 Visa's main competitor, Interbank, did not launch a debit card until 1980 (Interbank introduces a debit card, 1980, September 16). 
retail chains, JC Penney, to accept Visa cards, an activity which had, up until that time, been resisted by the three chains (Stearns, 2007, pp. 177-181). As part of the deal, JC Penney was to act as its own merchant acquirer and pay fees directly to Visa, rather than to a Visa acquiring bank. Stearns argues that many of Visa's members interpreted this not merely as a way of increasing acceptance of Visa's cards, but as Visa competing directly with its members. Stearns argues (p. 185) that this view led, in 1984, to the head of Visa, Dee Hock, eventually being forced to step down from the company.

\subsubsection{A New Approach to the Regulation of Banks}

During the 1980s, many of America's states moved away from geographical restrictions on banking activity by permitting statewide branching and inter-state banking via bank holding companies (Rhoades, 1997, pp. 997-998). This process culminated in federal legislation, the Riegle-Neal Interstate Banking and Branching Efficiency Act of 1994, which permitted inter-state banking via bank holding companies from 1995 and via branches from 1997. Rhoades (1997, p. 1001) says similar legislation enacted in 1980 and 1982 also reduced the legal barriers separating banking organisations from thrift institutions. The legislation allowed NBFIs to compete more effectively with banks by freeing the interest rates they could pay on deposits and by allowing them to offer new product lines from which they had previously been excluded, most notably commercial and industrial loans and transactions accounts. This process of deregulation is associated with a substantial decrease in the number of banking organisations in the US. From a total of 14,884 organisations in 1984, Jones and Critchfield (2005, p. 32) give evidence showing a 47\% decrease to a total of 7842 organisations in 2003.

Another piece of legislation affecting retail payment system development was the passing of the Monetary Control Act of 1980. It required that, from September 1981, the Federal Reserve Bank explicitly price the payment services they provided to banks, 
including cheque-clearing and $\mathrm{ACH}$ transfers (although other services remained nonpriced), and face budget cuts if the use of their services declined (Cavalluzzo, Ittner and Larcker, 1998, p. 2). Cavalluzzo et al report (p. 3) that the legislation was followed by the entry or expansion of a large number of competing clearinghouses and a reduction in the Federal Reserve Bank's cheque-clearing market share. They also find evidence that, while the Federal Reserve Bank improved efficiency in priced services, they reallocated costs from priced to non-priced services, particularly from cheque-clearing to other services. These observations are consistent with complaints from commercial banks and other ACH networks that the Federal Reserve failed to report the costs of its services accurately (Cavalluzzo et al, 1998, p. 2; Electronic Payments Network, 2004, pp. 12-13). Cavalluzzo et al suggest (p. 29) that the Federal Reserve did this to keep low prices for services facing competition in order to help maintain the levels of use of these services. This evidence suggests that the Federal Reserve Banks' prices for cheque-clearing were subsidised and remained below what they would have otherwise been.

\subsubsection{Payment System Development Following the Reforms}

\section{Online versus offline debit cards}

The legal uncertainty about the importance of branching restrictions to ATMs and POS terminals, which I described in subsection 4.8.1, was reduced in 1985 when the US Supreme Court affirmed an Appeals Court decision that ATMs not owned by banks were not bank branches (Scott, 1999, p. 1337). ${ }^{73}$ The decision clarified that non-bank owned ATM networks were not limited by states' bank branch restrictions and allowed the large scale development of such networks (Scott, 1999, p. 1337; Hayashi et al, 2003,

73 Scott clarifies that US courts held that bank-owned ATMs did represent branches until that position was explicitly repealed by Congress in 1996. 
pp. 13-14). The decision was followed by a significant consolidation in ATM networks with Hayashi and Wang $(2009$, p. 3) recording a fall in the number of networks from 120 in the mid-1980s to 30 in 2006. Hayashi and Wang (2009) attribute this consolidation to the adoption of debit card POS functionality by many networks. They find that larger ATM networks were more likely to adopt debit card innovation and those networks that adopted were more likely to survive than those that did not. Caskey and Sellon (1994, p. 86) report that "[w]hile only about half of ATM terminals were shared in the mid-1980s, almost all ATM machines belonged to a regional network by 1993." They argue this meant an increase in standardisation and allowed banks to better coordinate the introduction of online debit cards.

Neither Visa's nor MasterCard's members issued online debit cards before 1987 when the two organisations attempted to create an online debit card joint-venture called Entrée, the name that had been used for Visa's first offline debit card (Balto, 2000, pp. 1392-1393). The two companies proposed to combine their debit card operations with Visa's Californian POS system, Interlink, and their interests in two national ATM networks, Plus and Cirrus. As part of the joint-venture, Visa and MasterCard agreed not to introduce debit systems that would compete with Entrée. Balto (1998, p. 1095) reports that, while the US Department of Justice reviewed the joint venture and declined to challenge it, 14 State Attorneys General did challenge the joint-venture, alleging that the credit card schemes' joint-venture would retard the development of debit cards by inhibiting the entry or growth of smaller regional ATM networks in the debit card market. Visa and MasterCard settled in 1990 and agreed to abandon Entrée with both subsequently developing online brands: Visa developed Interlink and MasterCard created a new brand, Maestro. Balto (2000, p. 1393) reports both experienced moderate growth, but, for reasons that were unclear, chose to shift their promotion of debit cards from Interlink and Maestro to their offline debit cards, Visa Check and MasterMoney, 
in the mid-90s. These made use of the companies' already established credit card networks to indirectly access card holders' bank accounts (Balto, 1998). Unlike online debit, merchants did not need to buy or rent a POS terminal to accept payments (Sienkiewicz, 2002, p. 6). The inability of companies in the industry to find a commonly accepted solution to debit cards contributed to a development of the industry that Evans and Schmalensee (2008, p. 6) describe as "fragmented", with, according to Weiner and Wright (2005, p. 304), 14 interconnected, yet distinct ATM and debit card networks providing online services and with MasterCard and Visa providing offline debit card services. Chang (2004, p. 33) points out that only some cards provide access just to online networks with most providing it to both online and offline networks (with the number only providing access to offline networks being negligible). ${ }^{74}$

The fragmented nature of the debit card industry has resulted in consumers and merchants facing a range of fees for debit card use. As for credit cards, offline debit cards attracted proportional positive interchange fees, leading merchants to be "primarily" charged proportional MSFs for offline debit transactions while PIN debit transactions have largely incurred a flat MSFs (United States Department of Justice, 2003, p. 7). According to Hayashi et al (2003, p. 52), consumers faced no pertransaction fees, except banks that occasionally charged PIN fees for online debit card transactions. Hayashi, Sullivan and Weiner (2006, p. 13) cite a 2004 Federal Reserve Board survey of households as saying that $13 \%$ of respondents were charged PIN fees and fees ranged from US $\$ 0.1$ to $\$ 2$, with an average fee of about $\$ 0.75$.

Another result of this industry structure is that networks face high costs when introducing new payment instruments. Evans and Schmalensee (2008, p. 6) say that

74 Chang says that, at the time they complete a transaction, customers can choose which network to use, depending on which their merchant accepts. 
"innovation can be slow and may be biased towards improvements that are compatible with the existing infrastructure." Consistent with this, Povey (2008, p. 356) notes that the US is "extremely visible" in its lack of adoption of the EMV security standard, in spite of its location between two countries that have adopted the standard, Canada and Mexico. One media report indicates that US merchants have concerns about the lack of the country's adoption of EMV and wonder if a lack of the standard will cause a greater misuse of cards for which they are held liable (Diaz, 2010, September 29)?

\section{Increasing competition between networks for issuers of debit and credit cards}

In the mid-1990s, Visa's Interlink and MasterCard's Maestro did not receive as much use as the online debit networks of the regional ATM networks (Balto, 2000, p. 1393). When Visa and MasterCard began promoting their offline debit cards, however, they experienced a significant increase in competition for debit cardholders. This is reflected in figures offered by Hunt (2003, p. 89) showing that, while debit card transaction volumes grew significantly during the period, the proportion that were signature debit, as opposed to PIN debit, grew from about $40 \%$ in 1993 to $62 \%$ in 2002. Balto (1998, p. 1099) and Hayashi et al (2003, p. 80) both discuss how competition from offline cards forced online debit networks to raise interchange fees to attract issuers. ${ }^{75}$ Indeed, Hayashi et al (2003, pp. 77-78, 80) say that, while the payment of negative interchange was initially common for online debit card payment systems, the institution gradually fell out of favour before ending in 1997.

During this time, it appears that positive interchange fees for credit card transactions were also increasing. For credit cards, Simon (2005, p. 367) provides a graph showing the increasing average MSFs and MasterCard and Visa interchange fees from 1994 to

75 This is also reflected in a graph provided by Simon (2005, p. 368), which shows no clear trend in signature debit card interchange fees, but an upwards trend in PIN debit interchange fees between 1994 and 2004. 
2004 in the US. In an analysis of credit card rewards programmes, which had been first introduced in 1984 by Diners Club, Hayashi (2009, pp. 39) notes that programmes became more diverse during the 1990s, consistent with increasing fees paid by merchants. Indeed, competition for card holders appeared to intensify during this time. Mann (2002, p. 1068) points to the rise of "monoline" specialist credit card issuers that use sophisticated credit scoring techniques to assess cardholders' credit risk and reports that, in 1995, only $16 \%$ of MasterCard and Visa cards issued in the US were issued to cardholders that had any relationship with the issuing bank beyond the card. Evans and Schamlensee (2005a) devote a chapter of their book (Chapter 9) to describing the complex credit card issuing environment in the US. Increased competitiveness for cardholders is likely however to be reflected in increases in the MSFs paid by merchants. Evans and Schamlensee (2005a, pp. 185-188) discuss one expression of merchant discomfort about such fees, the 1991 Boston Fee Party, which involved more than 250 Boston restaurants threatening to end their acceptance of American Express unless it was willing to flexibly negotiate MSFs. American Express eventually relented and agreed to negotiate fees with individual merchants.

\section{Further ACH developments}

In spite of the new legislation described above that required the Federal Reserve Banks to impose explicit charges for services, private $\mathrm{ACH}$ operators continued to experience problems with the pricing, as well as the quality, of the Federal Reserve's ACH services (Electronic Payments Network, 2004, pp. 12-13). In 1994, three private operators formed the private $\mathrm{ACH}$ exchange (PAX) to enable them to exchange transactions without using the Reserve Banks and incurring the interregional fees these Banks had begun to charge. In 1996, after the Reserve Banks had consolidated their ACH operations in each of the twelve districts into one platform, a new system of prices was 
introduced that one of the three private operators, Electronic Payments Network (EPN), felt put it at serious competitive disadvantage (Electronic Payments Network, 2004, p. 12). EPN complained and the Federal Reserve Board reviewed the issue, deciding in 2000 that private operators were being disadvantaged; it instructed the regional Federal Reserve Banks to implement a new schedule of prices and deposit deadlines for its ACH services (Federal Reserve System, 2000). The Federal Reserve Banks and EPN became the only $\mathrm{ACH}$ service operators, with the market share of the latter increasing from 5\% in 2000 to approximately 40\% in 2005 (ibid, p. 16; The clearing house reinvented: Gaining a foothold in the future, 2005, July 21).

Recent developments related to the $\mathrm{ACH}$ system include decoupled debit cards and funds transfer systems accessed through the internet. Transactions made using decoupled debit cards are completed using the $\mathrm{ACH}$ system, with merchants being charged much lower fees than for transactions completed using traditional debit cards (Bradford, 2007, p. 2). Bradford notes that "[w]hile having experienced some measure of success with getting retailers to accept ACH-based debit cards, success with acquiring issuers has been more modest." The development appears to have continued, however, with Crowe (2008) describing a MasterCard-branded decoupled debit system, which may be used at any MasterCard-accepting merchant. Evans and Schmalensee (2005a, pp. 307-308) discuss internet-based funds transfer systems, saying that nearly all those attempting to create new currencies for the online environment, such as Flooz and Beenz, failed, while systems using existing infrastructure, such as payment cards and bank accounts, have experienced more success. They focus on Paypal, which was acquired by online auction company eBay in 2002 and which Shy (2010, p. 24) reports to be the one successful development of person-to-person electronic payments "over the years". Paypal makes use of the ACH system to transfer funds between its accounts and the bank accounts of its customers. 
Shy (2010) reports that, during 2009, several major commercial banks in the US began introducing a new online interface to allow customers to make electronic direct entry payments to any account in the US, using the ACH system. He compares this to the German direct entry system based on the Giro. Shy concludes that development should be encouraged and proposes that the Federal Reserve increases the prices it charges for cheque processing, while maintaining prices for $\mathrm{ACH}$ transactions, in order to give users a greater financial reason for using ACH-based instruments. This argument is surprising because, if indeed $\mathrm{ACH}$ transactions are cheaper to process than cheque transactions why are they not being priced so, already. Shy also briefly considers (p. 31) whether NBFIs should be granted access to the Federal Reserve's ACH system, but argues that this would make $\mathrm{ACH}$ payment completion more difficult because NBFIs cannot open accounts with the Federal Reserve, and would invite fraud.

\section{Other payment instruments}

Attempts to introduce contactless stored-value cards in the US are ongoing, but with little sign of success. Mitchell (2007, June 11) reports that Visa had said it had issued approximately 10 million payWave contactless cards with MasterCard issuing 13 million of its Paypass cards and signing up 46,000 merchants to accept them. Hernandez (2009, June 9) also outlines US transit authorities' ongoing attempts to introduce contactless cards, which started in 2006. In spite of these efforts, however, a noted academic specialising in payments, David Evans, described contactless payments in the US as being a "debacle", saying that merchants lacked reasons to invest in the technology to accept contactless payments and without them, consumers lack a good reason to get into the habit of using them much (Evans, 2010, September 29).

\subsubsection{Interventions in Retail Payment Systems}


In 1988, having abandoned by-laws preventing the duality of issuing MasterCard and Visa in the 1970s, the two schemes faced another challenge to their rules on membership summarised by Evans and Schmalensee (2005a, pp. 279-284). In that year the department store chain Sears, issuer of the successful Discover card, attempted to become a member of Visa. Visa stymied that attempt and, in 1990, Sears attempted to become a member by buying an insolvent member of Visa, the thrift institution, MountainWest.. When Visa also stymied this attempt, Sears filed an anti-trust suit, which became known as the MountainWest case. The Federal Appeals Court decided for Visa in 1994, reversing an earlier jury trial decision. However, following the appeal decision, the Department of Justice initiated a lawsuit in 1998 alleging that rules preventing member banks from issuing three-party cards, such as Discover and also American Express, were a conspiracy to restrain trade (United States Government Accountability Office, 2009, p. 20). The case was heard in the US District Court and its decision, reached in 2001, found that Visa and MasterCard were in breach of section 1 of the Sherman Antitrust Act. The trial judge required that Visa and MasterCard end their rules preventing their members from issuing three-party cards and rescind agreements they had signed with their members that encouraged members' loyalty to the schemes (United States Government Accountability Office, ibid; Evans and Schmalensee, 2005a, p. 283). The decision was upheld by the US Court of Appeals in 2003 and the US Supreme Court refused to hear Visa and MasterCard's appeal to it in 2004 (Crenshaw, 2004, October 5). As a result of the decisions, member banks could issue any combination of Visa, MasterCard, Discover or American Express cards (Prager, Manuszak, Kiser and Borzekowski, 2009, p. 37; Balto and Grube 2002, p. 1313). ${ }^{76}$ The United States Government Accountability Office (2009, pp. 20-21) noted

76 Evans and Schmalensee (2005a, p. 283) report that the District Court judge also allowed banks to issue either or both of Visa and MasterCard debit cards, thereby allowing duality for debit cards. 
that officials from Visa had attributed an increase in interchange fees to increased competition for issuers resulting from the decision. The report made observations about rising credit card interchange fees following the decision, noting that new interchange fees announced by Visa between 2003 and 2009 had raised those fees by 18\%, on average, while MasterCard's new fee announcements over the same period had raised them by $11 \%$. Some evidence indicates that, during a similar period, MSFs for threeparty credit/charge cards were declining. In 2007, American Express Chief Financial Officer, Gary Crittenden, described the longer term trend in American Express' MSF as being negative, "due to repricing and mix changes among various merchant categories...” (American Express merchant discount rate, 2007, January 23). This suggests three-party card networks have become more similar to four-party networks.

\section{Judicial action and the Honour-All-Cards Rule}

In 1996, a group of merchants filed lawsuits against Visa and MasterCard challenging the Honour-All-Cards Rule that required merchants to accept both schemes' debit and credit cards. The lawsuits were combined into a single, consolidated action that became known as the Wal-Mart case. The case was settled, out of court, in 2001 with Visa and MasterCard agreeing to pay the merchants over US\$3 billion in damages and to rescind the Honour-All-Cards Rule (Prager et al, 2009, p. 37). As I discussed in subsection 2.4.2, Rochet and Tirole (2008) show how the rule performs a socially beneficial rebalancing effect between the interchange fees charged by two platforms (such as debit and credit cards) facing different levels of competition. They point to support for their model coming from the observation that Visa and MasterCard reduced their debit interchange fees and increased their credit interchange fees following the removal of the Honour-All-Cards Rule in the US. 
In addition to the litigation described above, several cases in the US have dealt with the setting of interchange fees. The first, known as the NaBanco case, occurred in 1984, with the Federal District Court rejecting the argument that the multilateral setting of interchange fees was a restraint of trade (Smith, Lipsky, Robinson and Rinner, 2008). However, litigation dealing with interchange continued with the US Court of Appeals for the Ninth Circuit upholding, in a decision known as the Kendall Decision, a lower court's dismissal of merchant claims that credit card companies and banks violated antitrust law by conspiring to fix interchange fees (ibid). In 2009, a number of suits brought against MasterCard and Visa by merchants were consolidated in a case to appear before the US District Court (United States Government Accountability Office, 2009, pp. 41-42).

Further regulation of interchange fees appears likely in the US. The regulations will follow the passing of the Credit Card Accountability, Responsibility and Disclosure Act of 2009 (also known as the Credit CARD Act), which was signed into law in May 2009, placing restrictions on the interest rates and fees that issuers could charge consumers (Berlau and Radia, 2009, December). In the first half of 2010, three bills proposing the regulation of credit card interchange fees were before the US Congress (Zywicki and Frank, 2010, April 6). All were introduced during 2009 and, as Zywicki and Frank outline, involved attempts to use legislation to influence the negotiation of interchange fees by banks and merchants. One of the bills, the Credit Card Interchange Fees Act of 2009, would have negated Visa's and MasterCard's use of the No-Surcharge Rule (Rosenburg, 2010). None of the three bills passed, but attempts to regulate interchange fees continued. Late in 2010, the Federal Reserve proposed to introduce a cap of US\$0.07-0.12 for the interchange fees of debit cards under Section 1075 of the DoddFrank Wall Street Reform and Consumer Protection Act (Evans, Litan and Schmalensee, 2011). Although serious questions were raised about the suitability of the 
Federal Reserve's proposals by Evans, Litan and Schmalensee (2011) and Epstein (2010, December 29), among others, the final outcome of the Federal Reserve's proposals is as yet uncertain.

\subsubsection{Data Showing Payment Instrument Adoption in the United States}

My key data source showing the adoption of debit and credit cards in the US is transaction and population data available from CPSS (2009), which provides estimates of issued transactions. For the years 2000 to 2003, I use with data from an earlier Redbook, CPSS (2006). To corroborate this information, I use two editions of the paper, Federal Reserve Payments Study, containing information on credit and debit card transaction volume for the US for the years, 2000, 2003 and 2006 (Federal Reserve System, 2004; Federal Reserve System, 2007). It is unclear whether these reports contain series showing issued or acquired transactions. Nevertheless, the data for credit and debit card transaction volumes from the Federal Reserve publications are all within $5.5 \%$ (averaging $-1 \%$ ) of the data found in the CPSS publications.

\subsubsection{Bibliography for Summaries of the United States}

American Express merchant discount rate. (2007, January 23). Payment news, Retrieved from http://www.paymentsnews.com/2007/01/american_expres_2.html

Balto, D. (1998). Can the promise of debit cards be fulfilled? The business lawyer,53, 1093-1110

Balto, D. (2000). Creating a payment system network: The tie that binds or an honorable peace? The business lawyer; 55, 1391-1408

Balto, D. and Grube, B. (2002). The VISA-MasterCard decision and its implications for high tech markets. The business lawyer, 57

Baxter, W. (1983). Bank interchange of transactional paper: Legal and economic perspectives. Journal of law and economics, 26(3), 541-588

Berlau, J. and Radia, R. (2009, December). Payment card networks under assault: how capping interchange fees will hurt consumers, charities, community banks, and credit unions, Competitive enterprise institute issue analysis, No. 6, Retrieved from http://ww.cei.org/cei_files/fm/active/0/John\%20Berlau\%20and\%20Ryan\%20Radia\%20 -\%20Payment $\% 20$ Card\%20Networks\%20Under\%20Assault.pdf 
Berle Jr., A. (1949). Banking under the anti-trust laws. Columbia law review, 49(5), 589-606

Borzekowski, R., Kiser, E. and Ahmed, S. (2008). Consumers' use of debit cards: patterns, preferences, and price response. Journal of money, credit and banking, 40(1), $149-172$

Bradford, T. (2007). The evolution of the ACH. Payments system research briefing, Federal Reserve Bank of Kansas City, Retrieved from http://www.kansascityfed.org/Publicat/PSR/Briefings/PSR-BriefingDec07.pdf

Bulmer, J. (2009). Payment Systems: The debit card market in Canada. Library of Parliament: Information and Research Service, Retrieved from http://www2.parl.gc.ca/content/lop/researchpublications/prb0909-e.htm

Caskey, J. P. and Sellon Jr, G. H. (1994). Is the debit card revolution finally here? Economic review, Fourth Quarter, Federal Reserve Bank of Kansas City

Cavalluzzo, K.; Ittner, C. and Larcker, D. (1998). Competition, efficiency, and cost allocation in government agencies: Evidence on the Federal Reserve system. Journal of accounting research, 36(1), 1-32

Chang, H. (2004). Payment card industry primer. Payment card economics review, 2 , $29-46$

Committee on Payment and Settlement Systems [CPSS]. (2006). Statistics on payment and settlement systems in selected countries. Prepared by the Committee on Payment and Settlement Systems of the Group of Ten Countries, Publications No. 74, retrieved from http://www.bis.org/publ/cpss74.htm

Committee on Payment and Settlement Systems [CPSS]. (2009). Statistics on payment and settlement systems in selected countries. Prepared by the Committee on Payment and Settlement Systems of the Group of Ten Countries, Publications No. 88, retrieved from http://www.bis.org/publ/cpss88.htm

Crenshaw, A. (2004, October 5). Visa, MasterCard lose Supreme Court appeal. Washington Post

Crowe, M. (2008). Emerging payments - the changing landscape. Presentation given to the Federal Reserve Bank of Boston, Retrieved from:

http://www.bos.frb.org/economic/cprc/presentations/2008/crowe04151708.pdf

Diaz, J. (2010, September 29). Is the United States the weakest link when it comes to credit card security? SC Magazine, Retrieved from http://www.scmagazineus.com/isthe-united-states-the-weakest-link-when-it-comes-to-credit-card-

security/article/179916/

Durkin, T. (2000). Credit cards: Use and consumer attitudes, 1970-2000. Federal Reserve Bulletin, September, 623-634

Electronic Payments Network. (2004). The Electronic Payments Network and the ACH: A history, Retrieved from http://ezpay.org/cms/documents/001743.pdf 
Epstein, R. (2010, December 29). Government price controls on your wallet ; New regulations threaten banking disaster. The Washington Times

Evans, D. (2010, September 29). Why even great payments ideas crash and burn, Pymnts.com commentary, Retrieved from http://www.pymnts.com/why-even-greatpayments-ideas-crash-and-burn/

Evans, D. S. and Schmalensee, R. (2005a). Paying with Plastic: the Digital Revolution in Buying and Borrowing, Second Edition, Massachusetts: The MIT Press

Evans, D. and Schmalensee, R. (2005b). The economics of interchange fees and their regulation: An overview. MIT Sloan Working Paper in Interchange Fees in Credit and Debit Card Industries, Kansas City: Federal Reserve Bank of Kansas City, 73-120

Evans, D. S. and Schmalensee, R. (2008). Innovation in Payments. Market Platform Dynamics, Retrieved from: http://papers.ssrn.com/sol3/papers.cfm?abstract_id=1277275

Evans, D.; Litan R. and Schmalensee, R. (2011). The economic principles for establishing reasonable regulation of debit-card interchange fees that could improve consumer welfare. Retrieved from http://ssrn.com/abstract=1769890

Federal Reserve System. (2000). Modifying Federal Reserve ACH deposit deadlines and pricing practices relative to private-sector ACH operators, Retrieved from http://www.federalreserve.gov/boarddocs/press/BoardActs/2000/20000523/attachment. $\underline{\mathrm{pdf}}$

Federal Reserve System. (2004). The 2004 Federal Reserve payments study. Retrieved from http://www.frbservices.org/files/communications/pdf/research/2004PaymentResearchR eport.pdf

Federal Reserve System. (2007). The 2004 Federal Reserve payments study, Retrieved from http://www.frbservices.org/files/communications/pdf/research/2007_payments_study.pd $\underline{\mathrm{f}}$

Hayashi, F. (2009). Do U.S. consumers really benefit from payment card rewards? Economic review, Federal Reserve Bank of Kansas City, 37-63

Hayashi, F, and Wang, Z. (2009). Product innovation and network survival: The U.S. ATM and debit card industry. The Federal Reserve Bank of Kansas City, Economic Research Department, Research Working Paper, RWP 08-14, 6 July

Hayashi, F., Sullivan, R. and Weiner, S. (2003). A guide to the ATM and debit card industry. Payments System Research Department, Federal Reserve Bank of Kansas City

Hayashi, F., Sullivan, R. and Weiner, S. (2006). A guide to the ATM and debit card industry: A 2006 update. Payments System Research Department, Federal Reserve Bank of Kansas City

Hernandez, W. (2009, June 9). Contactless cards making inroads on transit systems. American Banker, 174(109) 
Hunt, R. (2003). An introduction to the economics of payment card networks. Review of network economics, 2(2)

Jones, K. and Critchfield, T. (2005). Consolidation in the U.S. banking industry: Is the "Long, Strange Trip" about to end? FDIC banking review, 17(4),31-61

Kane, E. (1996). De jure interstate banking: Why only now? Journal of money, credit and banking, Vol. 28, No. 2, pp. 141-161

Mandell, L. (1990). The credit card industry: A history, Boston: Twayne Publishers

Mann, R. (2002). Credit cards and debit cards in the United States and Japan.

Vanderbilt law review, 55(4)

McAndrews, J. (1991). The evolution of shared ATM networks. Business review, Federal Reserve Bank of Philadelphia

Mitchell, R. (2007). No contact RFID-based contactless payment cards are fast, secure and largely unused. Smart phones may be called in to help. Computerworld, 24

Interbank introduces a debit card (1980, September 16). New York Times

Povey, I. C. (2008, June). Assessing the impact of EMV migration: A pragmatic delivery approach. Journal of payments strategy \& systems, 2(4), 349-363

Prager, R.; Manuszak, M.; Kiser, E. and Borzekowski, R. (2009). Interchange fees and payment card networks: Economics, industry developments, and policy issues, Finance and economics discussion series, Federal Reserve Board, Washington, D.C., 2009-23

Rhoades, S. A. (1997, Winter). Have barriers to entry in retail commercial banking disappeared? The antitrust bulletin, 42, 97-113

Rochet, J. and Tirole, J. (2008). Tying in two-sided markets and the Honor All Cards Rule. International journal of industrial organization, 26, 1333-1347

Rosenburg, A. (2010). Point-of-purchase bank card surcharges: The economic impact on consumers. New America Foundation: Asset building program issue brief, Retrieved from

http://assets.newamerica.net/sites/newamerica.net/files/policydocs/Surcharging_May_2 $\underline{010 . p d f}$

Schooner, H. and Taylor, M. (1999). Convergence and competition: The case of bank regulation in Britain and the United states. Michigan journal of international law, 20, 595-655

Scott, K.E. (1999). Electronic commerce revisited. Stanford law review, 51(5), 13331342

Shy, O. (2010) Person-to-person electronic funds transfers: Recent developments and policy issues. Federal Reserve Bank of Boston public policy discussion papers, No.10-1

Sienkiewicz, S. (2002). The evolution of EFT networks from ATMs to new on-line debit payment products, Discussion Papers, Federal Reserve Bank of Philadelphia, April, 
Retrieved from http://www.philadelphiafed.org/payment-cardscenter/publications/discussion-papers/2002/EFTNetworks_042002.pdf

Simon, J. (2005). Payment systems are different: Shouldn't their regulation be too? Review of network economics, 4(4), 364-383

Smith, B.; Lipsky, A.; Robinson, A. and Rinner, W. (2008). Why the market should set credit card interchange fees. Bank accounting \& finance, legislative comment, 39-44

Stearns, D. L. (2007). “Think of it as Money”: A History of the VISA Payment System, 1970-1984 (Doctoral Dissertation). University of Edinburgh, Retrieved from http://www.era.lib.ed.ac.uk/bitstream/1842/2672/1/Stearns\%20DL\%20thesis\%2007.pdf

The clearing house reinvented: Gaining a foothold in the future. (2005, July 21).

Electronic payments week

United States Department of Justice. (2003). Plaintiffs' pretrial brief: United States of America et al v. First Data Corporation and Concord EFS, Inc., 1:03CV02169 (RMC), December 10, 2003

United States Government Accountability Office. (2009). Credit cards: Rising interchange fees have increased costs for merchants, but options for reducing fees pose challenges, Report to Congressional Addressees, Retrieved on November 262009 from http://www.gao.gov/new.items/d1045.pdf

Weiner, S. and Wright, J. (2005, December). Interchange fees in various countries: developments and determinants. Review of network economics, 4(4)

Zinman, J. (2009). Debit or credit? Journal of banking and finance, 33(2), February, 358-366

Zywicki, T. and Frank, J. (2010). Regulation of payment card interchange fees. The Federalist Society for Law and Public Policy Studies, Retrieved from http://www.fedsoc.org/doclib/20100406_NFIPInterchange.pdf 


\subsection{Lessons from my Historical Summaries}

\subsubsection{Australia}

In subsection 4.1.1, I described actions associated with the Australian Federal Government that appear to have had major effects on retail payment system development. Firstly, its regulation of Australia's financial system distinguished between banks and NBFIs with banks showing an unwillingness to cooperate with NBFIs, reducing inter-network competition. Consistent with a lack of such competition, evidence suggests that the operations of Australia's bank's first credit card, Bankcard, were collusive. Secondly, an Australian Government review of the finance industry called for NBFIs to be given access to banks' centralised inter-bank transfer system, CEMTEX. Shortly after the review's publication, banks disbanded CEMTEX, instead exchanging direct entry transactions bilaterally. I argue that this reflects banks perceiving that they did not hold full property rights over the CEMTEX network. I also argue similar perceptions of property rights and issues with cooperation between banks and NBFIs were reflected in banks developing two other payment networks in a decentralised manner, EFTPOS and Bankcard. As I described in subsection 4.1.2, Australia's regulatory environment continues to distinguish between banks and NBFIs; the only successful attempt to create a centralised payment network appears to have been the bill payment service, BPAY, which I described in subsection 4.1.3.

In subsection 4.1.4, I described the serious interventions in the operations of payment networks made by the RBA. Specifically, the RBA intervened to control positive and negative interchange fees charged for credit cards and EFTPOS and remove networks' use of the No-Surcharge Rule. Furthermore, it has shown a continued interest in the network operations by regulating ATMs and indicating the possibility of regulation of 
the payment networks, BPAY and Paypal. Evidence points to the effects of the RBA's reforms:

- the fees paid for payment instrument use have been redistributed between merchants and consumers, but in ways that were not intended by the RBA ${ }^{77}$

- $\quad$ evidence suggests that, when they occur, merchant surcharges exceed MSFs for credit card transactions, showing that the RBA's efforts to allow surcharging have increased the total cost of paying by credit card and

- $\quad$ uncertainty created by the reforms appears to have resulted in a decrease in competition with evidence indicating major payment card issuers did not enter Australia markets because they prefered to enter where conditions are more stable.

Furthermore, in its conclusions to its 2007/2008 review of the effects of its regulation, the RBA announced that it might step back from regulation if banks enhanced Australia's EFTPOS network and if the RBA received voluntary assurances that positive interchange fees for credit cards would not be increased as well. In August 2009 , however, it announced that progress was not sufficient in these respects and its regulation would be retained. In spite of this continued interest in regulation, however, an opportunity appears to exist for the RBA to re-consider its approach as part of a recently announced review of innovation in Australian retail payment systems.

\subsubsection{Canada}

In subsection 4.2.1, I described the passing of the Canadian Payments Association Act in 1980 established the CPA (the Canadian Payments Association) and dictated that only certain organisations were to be members of it and participate in inter-bank

77 Specifically, Chang et al (2005) find that cardholder fees have mainly been increased through higher fixed fees, making little difference to cardholders' per-transaction fees or benefits, contrary to the RBA's stated intention of encouraging relative prices to reflect relative resource costs. 
payment networks in Canada. Quigley (1996) argues that the Act was a rejection of the idea that competition should shape the evolution of the Canadian payments system. Indeed, competition was not sufficient to encourage the CPA's offshoot, Interac, to provide a full range of services from its ATMs. Moreover, Interac's chartered members appeared unwilling to cooperate with non-chartered members, including by impeding the attempt of American Express to become a member in $1988 .^{78}$ A complaint from American Express about the matter eventually led to a review of Interac by the responsible government authority, the Director of Investigation and Research. This review resulted in changes to Interac's operations, including an expansion of its membership, a requirement that it set prices only to recover its costs and the removal of its No-Surcharge Rule. The small amount of evidence I've found indicates that the Rule's removal resulted in an increase in the total costs of Interac debit card transactions.

In subsection 4.2.2, I described the passing of the Canadian Payments Act 2001, which resulted in an expansion of the membership of the CPA. In spite of the increased membership, however, problems with cooperation between members and non-members continued: one non-member bill payment service provider, Usemybank, complained about its treatment by CPA members and the CPA went as far as to pass rules in 2003 and 2005 that impeded member/non-member cooperation. ${ }^{79}$ These events happened in spite of significant concerns about the standard of service offered for bill payments by the CPA being voiced at a Canadian Government committee meeting. The concerns led to the CPA publishing a report in which it admitted that evidence indicated $80 \%$ of bill

78 I also refer to the Express and Access ATM payment networks created in 1984/85, which did not succeed because, reportedly, they were not able to link with Interac.

79 I refer to a CPA rule passed in 2003 that prevented the processing of certain telephone-based payments called tele-cheques during clearing and one passed in 2005 that required all bill payments processed during clearing be initiated using the CPA member's own website, precluding the use of a third party's website. 
payments occurred outside of the CPA's bill payments framework. ${ }^{80}$ In spite of these issues with Canadian retail payment systems, however, further interventions in payment operations look likely. In subsection 4.2.4, I described proposals that Canadian government authorities intervene in debit and credit card operations of payment networks there.

\subsubsection{Europe}

In section 4.3, I described the influence of the European Union on the three European countries in my sample, Germany, Norway and the UK. Within the Union the European Commission can pass Regulations, which immediately become enforceable as law in member states, and Directives, which direct Union members to put particular legislative frameworks in place. The Commission has also influenced the development of retail payment systems, particularly debit and credit cards, by conducting investigations of interchange fees and network rules. I argued, however, that these investigations were beyond the scope of my thesis because they only directly affected a small proportion of transactions, those occurring cross-border, and only payment instruments that are already established (debit and credit cards).

In subsection 4.3.2, I did identify one group of European Commission decisions affecting a retail payment system that had yet to receive much development, its Directives relating to electronic money. I identified a paper describing the interest of the European Central Bank in electronic money, as well as two Directives passed in 2000 by the Commission, instructing Union members to put in place prescriptive legislative frameworks for the issuing of electronic money. 


\subsubsection{Germany}

In subsection 4.4.1, I described the structure of the German banking industry, including how it is composed of three pillars, commercial banks, cooperative banks and public banks with the latter two having less of a profit motive than the first. Additionally, each of the pillars are led by associations that can make decisions binding on their members, with a central association, the ZKA, governing all of the pillars. The industry can be characterised by a lack of inter-network competition with, for example, only one jointlyowned organisation, the GZS, conducting almost all of Germany's credit card issuing and acquiring until the 1990s.

In subsection 4.4.3, I described the introduction in 1990 by the ZKA of the Electronic Cash debit card, following lengthy negotiations. Given the delays in creating it, the MSFs charged for its use and the fact that merchants could only obtain terminals and acquiring services from the GZS, merchants were not supportive of the new system. The intervention of the Bundeskartellamt, the Federal Cartel Office, meant an open system was adopted that allowed merchants to obtain terminals and use the services of companies other than GZS. This led to the creation of the Netzbetreiber, the payment network operator, from which merchants could obtain terminals and Electronic Cash acquiring services. At the time Electronic Cash was being introduced, however, one German merchant introduced the ELV debit card payment network, which operated by using the account details on an Electronic Cash card to generate a direct debit to be paid from a customer's account to a merchant's. Although ELV operated without a payment guarantee, meaning a merchant risked not being paid for a fraudulent transaction or when a consumer had insufficient funds in their account, the instrument proved popular with merchants because MSFs were not charged for its use. In the early 2000s, ELV appears to have been more popular than Electronic Cash as a debit card payment 
instrument. Electronic Cash was renamed Girocard in 2007 and ELV was renamed, ec direct debit in 2009.

In 1997, Germany amended its banking law to restrict the issuance of electronic money to banks, in order to update its law with trends in European law. That same year, Germany's banks rolled out the Geldkarte stored-value payment instrument nationwide. The rollout was not well supported by the pillar of banks that are argued to have the strongest profit motive, the commercial banks. The development of Geldkarte does not appear to have been successful, with one Geldkarte manager admitting that the company no longer focuses on marketing the instrument at attended POS because it was "very difficult" to market the instrument there.

Finally, in subsection 4.4.5, I discussed my research to check the veracity of data showing significantly less adoption of debit and credit cards in Germany relative to the other countries in my sample. While that research does not refute the data, it does suggest that it may under-estimate the extent of debit and credit card adoption in the country.

\subsubsection{New Zealand}

In subsection 4.5.1, I described significant government controls that regulated New Zealand's financial industry, distinguishing between trading banks, trustee savings banks and other financial organisations. Retail payment system development events from that time suggest the groups of organisations were unwilling to cooperate with each other. New Zealand's central bank was required to act as arbiter when other organisations sought access to the trading banks' cheque-clearing system and the trading banks and trustee savings banks maintained separate pilots of EFTPOS systems. I described in subsection 4.5.2, new legislation passed by the New Zealand Government 
in 1986 that removed the regulatory distinctions that had existed, allowing any organisation that met explicit prudential criteria to become a 'registered bank'.

Following the creation of the new regulatory environment, New Zealand's financial organisations became more willing to cooperate with each other. Additionally, a new state of (potential) inter-network competition existed. As they re-created the formertrading banks' EFTPOS pilot, two banks reacted to competition from New Zealand's other EFTPOS pilot by creating an EFTPOS payment network that operated without charging MSFs. This approach proved robust and the former trading banks' cooperated when they merged their EFTPOS network with that of the former trustee savings banks. Inter-network competition was also a factor in the creation of New Zealand's inter-bank transfer system, ISL, when one bank, frustrated with the low level of service from the incumbent inter-bank system, set up a competing system. This caused the banking owners of the incumbent to improve the quality of its service and open access to the system. New Zealand has also seen the development of a stored-value system, through a network operated by a private provider of bus services. I have not observed any other privately-owned, public transport-based networks in my sample countries.

New Zealand's competition regulator reached settlements with MasterCard, Visa and New Zealand banks in 2009 that regulated interchange fees and ended their use of the No-Surcharge Rule. While initial evidence indicated that little surcharging was starting to occur, the regulator issued a press release not long after the settlements that suggested it believed the surcharging that was occurring was excessive.

\subsubsection{Norway}

In subsection 4.6.1, I described the heavy involvement of the Norwegian Government in the banking system in Norway following World War 2, including its control of both interest rates and investment. From the late 1970s, this control was gradually wound 
back. In the late 1980s/early 1990s, however, the Norwegian banking system experienced a serious liquidity crisis that resulted in major injections of funding by the Norwegian Government and the nationalisation of three major banks.

During this period, some retail payment system developments occurred with the creation of giro direct entry payment networks and ATMs. There was some experimentation during the 1980s with debit card payments at the POS. With some coordination from Norway's central bank, Norwegian banks cooperated to from the debit card payment network, BankAxept. The pricing structure chosen for BankAxept appears to have partly been the outcome of a political process with banks being encouraged to explicitly price payment instrument use for consumers, in the face of resistance from unions. This pricing structure did, however, prove successful at encouraging the largest number of debit card transactions in my sample countries, although this might partially be a reflection of the importance in Norway of bank overdrafts, which are accessible using a BankAxept debit card, as a source of consumer credit.

In subsection 4.6.4, I described the continued interest of Norway's central bank and other government authorities in payment network operations. Examples of this interest include a 2008 press release from the Norwegian central bank warning that reducing prices faced by consumers for many payment services or offering them free of charge was not in consumers' best interest. Another area of interest has been stored-value payment networks, caused by the introduction of intrusive electronic money legislation implementing European Union Directives. I have not identified any stored-value networks that have been successfully developed in the face of this legislation. 


\subsubsection{United Kingdom}

In subsection 4.7.1. I described the development of a number of new payment instruments in the UK, including charge and credit cards, ATMs and cheque guarantee cards. Development of one other instrument occurred more slowly, however. In spite of banks beginning to investigate options for debit card systems in 1974, it was not until 1985 that serious development started to occur. Even once it had started, however, development of the payment network that became EFTPOS UK appeared problematic. EFTPOS UK introduced an encryption standard, RSA, that was not thought to be compatible with the more commonly used standard, DES, in spite of DES being used for an EFTPOS UK member's existing debit cards. This suggests that EFTPOS UK members were not interested in the network's long term success - indeed, EFTPOS UK was wound up following an initial trial and its members subsequently developed their own debit card networks. I have not been able to document the reasons for the lack of motivation for members. One factor that does appear to play a role, however, is the involvement of the UK central bank, the Bank of England in EFTPOS UK, which caused its members to perceive they were not able to cooperate to form alternative networks.

In subsection 4.7.2, I described a new approach to the regulation of the UK's banks that involved greater formalisation regarding the role of the Bank of England and the creation of the FSA (the Financial Services Authority) to administer the country's prudential supervision. The process has, however, been described as re-regulation rather than de-regulation and concerns have continued to be expressed about the standard of competition in the UK's banking industry, including by the Cruickshank Report. This Report identified that an informal contract existed between successive UK Governments and the country's banks, which it argued contributed to competitive problems. The Report also expressed concerns about the amount of innovation in retail 
payment systems in the UK. On analysing the evidence, I relate this lack of innovation not to competition, but to perceptions that inter-bank payment network investments are non-excludable in the UK. I have not managed to document the reasons for this perceived non-excludability and it remains an aspect for further research. Evidence indicates a more obvious impact of the UK's electronic money legislation, which implemented European Union Directives, but made it prohibitively costly to use London's successful Oyster stored-value card for purchases not involving public transport.

\subsubsection{United States}

In subsection 4.8.1, I summarised the development of payment instruments in the US that was significantly affected by government restrictions on bank branching. Banks created cards that offered consumers access to a line of credit, competing with payment cards offered by several non-banking organisations. They developed associations for their credit cards in order to increase the number of merchants accepting their card and the number of consumers wishing to use it while not breaching bank branching restrictions. These associations eventually developed into the global credit card brands, Visa and MasterCard. Development of debit cards was more modest and it was not until the development of the POS terminal in the late 1970s that electronic debit card payments were technologically feasible. However, legal uncertainty about whether POS terminals constituted bank branches, for the purposes of branching restrictions in the US, appears to have stymied attempts to further develop debit cards in the US. In subsection 4.8.1, I also outlined the role of the Federal Reserve in cheque-processing that followed its creation in 1913, including the development of an electronic alternative to cheques, ACH payments, during the 1960 s and ' 70 s. 
In subsection 4.8.3, I described a 1985 Supreme Court case that reduced much of the legal uncertainty about the legal status of POS terminals. Following the decision, networks that had operated just ATMs began also offering online POS debit card services, resulting in a dramatic decline in their numbers. Visa and MasterCard attempted to use their credit card association structures to coordinate debit cards when they proposed to introduce the online debit card joint venture, Entrée. In spite of the US Department of Justice reviewing the joint venture and declining to challenge it, 14 State Attorneys General did challenge it, resulting in Visa and MasterCard abandoning the proposal in 1990. In the mid-1990s, Visa and MasterCard began successfully promoting their offline debit cards, developing them alongside the online PIN debit card networks. The mix of the two types of network has created a "fragmented" structure to the debit card payment system in the US. Concerns have been raised that this makes innovation slow and biased towards improvements that are compatible with existing infrastructure. Consistent with this, the EMV security standard has yet to be introduced in the US, in spite of it being introduced in countries either side of the US, Canada and Mexico and as well as in all of my other sample countries.

In subsection 4.8.3, I also described the developments in direct entry payments in the US. The development of electronic forms of such payments in the US appears to have been substantially affected by the actions of Federal Reserve, particularly its pricing of cheque-clearing services. Although the Federal Reserve's pricing has not entirely prevented the development of online direct entry payments between bank accounts in the US using the ACH system, a Federal Reserve employee published a paper in 2010 arguing that the Federal Reserve should encourage such developments by raising its prices for cheque-clearing while maintaining its prices for $\mathrm{ACH}$ services. That it takes an employee to publish an article arguing for changes in pricing raises concerns about the Federal Reserve's current approach to pricing. 
In subsection 4.8.4, I described serious judicial interventions in the operations of payment networks, including the end of networks' use of the Honour-All-Cards Rule and the end of by-laws preventing member banks from issuing three-party cards such as Discover and American Express. Evidence suggests that both actions resulted in an increase in the MSFs charged for credit card transactions. It may, however, be difficult to isolate the effects of each action, particularly of the second, because of increasing competition for holders of both credit and debit cards that was taking place during this time. In spite of increasing competition, further interventions look likely with the US Federal Reserve suggesting a cap be applied to interchange fees for debit cards. 


\section{Chapter 5}

\section{Analysis of Retail Payment System Development}

In this Chapter, I use the research I have conducted to create a framework for considering the development of retail payment systems. I start by outlining the nature of retail payment systems in section 5.1, before considering the demand for the instruments offered by the payment networks that are part of those systems in section 5.2. In section 5.3, I analyse the supply of instruments by these networks, using this analysis to lead into a discussion of the role of government in retail payment systems in section 5.4.

\subsection{Nature of Retail Payment Systems}

The payment networks that make up a retail payment system provide platforms, payment instruments, across which users interact to complete transactions between them. According to the process I set out in section 5.2, users will choose the instrument that allows them to interact by completing their transaction at lowest cost. Transaction costs will therefore be of a fundamental importance to the development of retail payment systems. The analysis of transaction costs is complex, however. In subsection 2.3.1, I summarised the analysis of Milgrom and Roberts (1992) who investigated the relevance of transaction costs to institutional design. They argue that transaction costs are not always being logically distinct from production costs and competition may not always be sufficient to cause transaction costs to be minimised. In response to such concerns, I start my sections covering the demand and supply of retail payment systems with a discussion of how I treat transaction costs.

While all payment instruments might aid the exchange of money between merchants and consumers, not all are merchant-based. As I explained in section 1.4, information on usage and pricing are generally available, in combination, only for card-based, 
merchant-based instruments in my sample countries. Accordingly, I focus on these when I use the available data to develop analysis of instrument demand in section 5.2. In section 2.1, however, I pointed to evidence indicating the rise of new consumer-based instruments that use mobile phones and I suggest ways in which they might be considered, using the framework I create. No similar constraints exist on data for historical events and I use this data when I turn to their supply by payment networks in section 5.3 and the role of government in section 5.4.

\subsection{Demand for Payments Instruments}

An instrument will be preferred if it reduces transaction costs associated with trading between consumers and merchants compared to other instruments. These costs I refer to as, demand-side transaction costs. As I discussed in subsection 2.3.1, I use the definition of transaction costs suggested by Dahlman (1979). Of his three categories, I argue the most relevant to instrument demand will be costs falling into the two categories of search and information costs and bargaining and decision costs. I argue that the former captures the ease with which consumers and merchants find instruments suitable for the completion of their transactions, while the latter captures the ease with which consumers and merchants use an instrument to complete those transactions (for example, the length of time it takes to complete a transaction using an instrument). In Table 1.1 in my introduction, I highlighted that the protection of private property rights was relatively strong in each of the countries I study. Accordingly, I do not further analyse policing and enforcement costs for payment instruments, although I acknowledge these will be a greater issue in countries without a similar level of protection of property rights.

The multitude and variety of merchants and consumers, no-less of the transactions between them, means that assessments of each instrument along a single dimension, 
such as price or per-transaction fees, will be insufficiently informative. ${ }^{1}$ Payment instruments will become differentiated products, assessed on their suitability for different transactions according to their attributes. In subsection 5.2.1, I analyse the characteristics over which consumers and merchants will have preferences, before further analysing the process they use to choose a merchant-based instrument to complete their transactions with. In subsection 5.2.2, I use that analysis to describe the method by which instruments are selected, before summarising the aspects of instrument demand that contribute to the importance of network effects in subsection 5.2.3. In subsection 5.2.4, I analyse aspects of newly introduced merchant-based instruments and of the pricing and adoption of debit card systems to investigate the relative importance of merchants' acceptance of, and consumers' preference for, different payment instruments. I show that it is the relative importance, firstly, of encouraging merchants to accept an instrument, rather than of consumers wishing to use it, that is key to retail payment system development.

While I assess factors that raise transaction costs for both merchants and consumers, I make no attempt to aggregate these to an index. Instead, I rely on revealed preference (which instrument gets used) to tell me which instruments are accepted by merchants and preferred by consumers because they reduce demand-side transaction costs. Because of my decision not to aggregate these costs for the two groups, I find the description, to minimise (demand-side) transaction costs, unhelpful - minimising implies demand-side transaction costs are minimised for both consumers and merchants for every transaction. Instead, I conclude that the instrument used generally reduces

\footnotetext{
As further support for this statement, I point to the work of Bolt et al (2008) who found the use of explicit payment instrument pricing in Norway accelerated the shift to electronic payment systems by approximately 20 percent, compared to adoption in the Netherlands where no explicit pricing was used. This observation indicates that factors as well as pricing are important to consumers.
} 
transaction costs for consumers and merchants because, if it did not do so, merchants would not choose to accept it at the same time that consumers chose to use it.

\subsubsection{Desired Attributes of Payment Instruments}

Consumers and merchants will prefer to use payment instruments that minimise the costs of their transactions with each other. In order to assess the causes of transaction costs, I start by investigating consumers' and merchants' preferred attributes of the instruments they use. Two papers I described in subsection 2.4.1, Borzekowski et al (2008) and Arango and Taylor (2008), indicate the attributes of utility for consumers and merchants, respectively. This subsection analyses choices between payment instruments, using these attributes and the theories I have reviewed to show how attributes affect demand and interact. I develop Table 5.1 below, which synthesises important attributes of payment instruments for consumers and merchants. Because I focus on merchant-based instruments in this section, I consider relevant attributes for merchants and consumers together. For the purposes of comparison, however, I include in Table 5.1, two payment instruments that are not merchant-based, cash and computerbased instruments.

I start with the consumer preferences given by Borzekowski et al (2008) and, in place of the preference for acceptance by merchants, use merchants' desired attributes, as indicated by Arango and Taylor (2008). Of merchants' attributes, however, I do exclude intensity of use because I believe it reflects consumer demand for instruments. Some attributes will be relevant to both consumers and merchants. I have specified where an attribute relates to just one or both of those parties. For the sake of simplicity, I assign Borzekowski et al's attributes, restraint and tracking, to the attribute of convenience. I also include a measure of the liquidity constraint associated with a payment instrument, the importance of which was indicated by Schreft (2006) when she 
described the complex, inter-temporal decisions that occur when consumers decide to use a particular payment instrument. Additionally, I have phrased the attributes to make a low rating more preferable (for example, I have used the attribute, inconvenience, rather than convenience).

I use the attribute of inconvenience to measure the inconvenience of using an instrument for POS payments and for remote payments because particular instruments are often unsuited to one of these two types of payments. The need for users to incur account fees to access a payment instrument and the need in all of the countries I have studied for merchants to buy or rent terminals means I separate financial costs (including pecuniary benefits) for merchants and consumers into fixed costs of obtaining access to a payment instrument and the marginal costs paid each time an instrument is used (pertransaction fees). I also consider the inconvenience and the liquidity constraint imposed by an instrument for merchants as well as for consumers. At this stage, I assume merchants do not surcharge or discount transactions paid for with particular instruments, an assumption I relax when considering competition over instrument attributes in subsection 5.2.2.

Table 5.1 summarises my subjective assessments of these attributes for major payment instruments that are commonly used for domestic transactions. ${ }^{2}$ It shows my snapshot, taken at the present time, of whether an instrument has a low, medium or high amount (L, M or $\mathrm{H}$ ) of a particular attribute, relative to other payment instruments. I note that these attributes are not mutually exclusive and ratings will naturally change over time. Finally, I assume both the consumer and merchant maintain one bank account into which is paid their wages and revenue.

2 I note that only credit cards and scheme-based debit cards, being based on Visa, MasterCard or similar scheme, are generally used for transactions in other countries other than the one they were issued in. 


\section{Table 5.1. Table of Commonly Used Payment Instruments' Attributes}

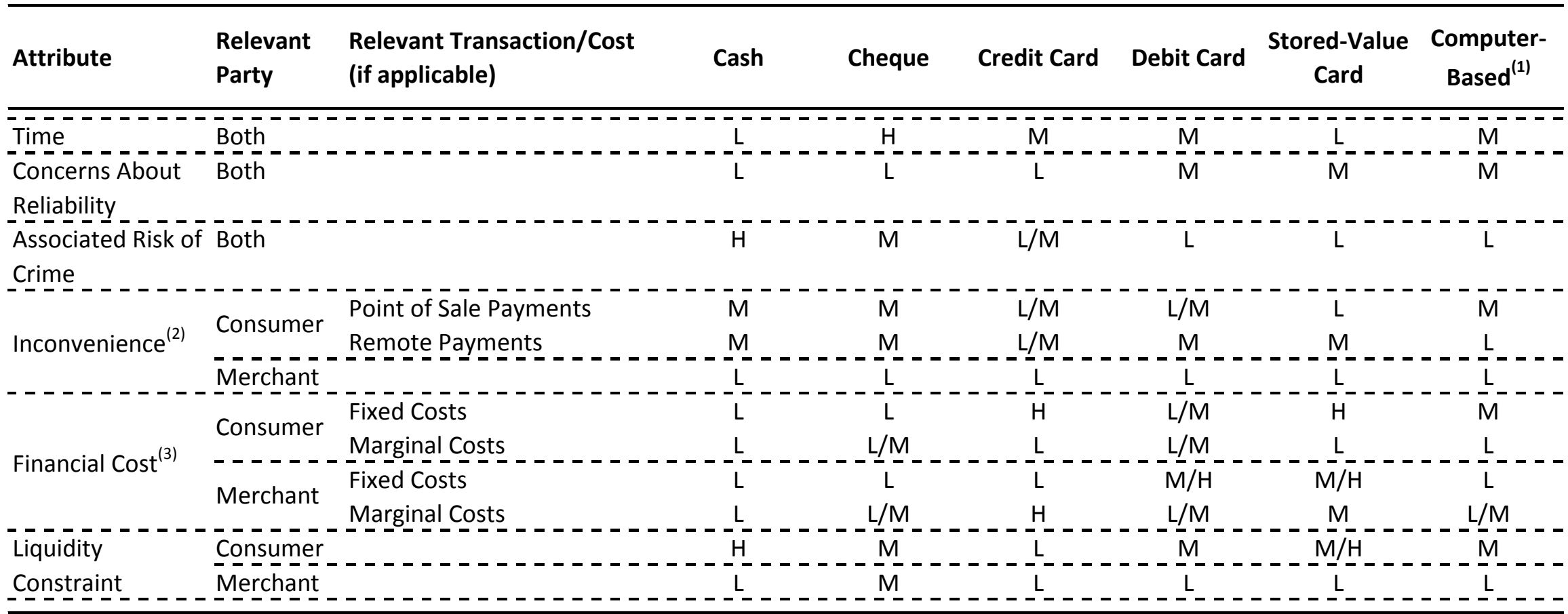

NB: Assumes consumers and merchants maintain one bank account for general purposes

(1) Includes instruments such as Paypal

(2) Includes implied interest cost

(3) Includes reward points (a negative financial cost) 


\section{Explanation of my ratings of attributes}

Table 5.1 assumes that it takes less time to process transactions made using cash or stored value cards than it does other payment instruments because those other instruments generally require the customer to use a PIN or signature for identification. ${ }^{1}$ Because cash, cheque and credit cards have been used as payment instruments for longer, I assume merchants and consumers commonly have fewer concerns about their reliability. Debit card, stored-value card and computer-based instruments are more reliant on recently developed technology and I assume that they are perceived as less reliable. $^{2}$

The crime associated with payment instruments might come from fraudulent use by other consumers (including from theft) or fraudulent use by merchants or merchants' agents. Because it is anonymous and largely untraceable, cash has the highest risk of being stolen. Reliance on signatures for customer identification means a greater risk of crime associated with cheques and, to a lesser extent, credit cards than with debit cards, which are commonly PIN-protected, or computer-based instruments, which are commonly password-protected. Stored-value cards require none of PINs, passwords or signatures for customer identification implying they may be associated with a greater risk of crime. However, because of this, consumers are more likely to limit the funds available using their stored-value cards compared to other payment instruments.

Furthermore, since transactions made using stored-value cards are more traceable than cash, they may be associated with substantially lower risk of crime. For example, the introduction of the stored-value card, Snapper, on buses in New Zealand resulted in the

$1 \quad$ Although I do not adjust my attribute rating for time for credit or debit card, I note Zinman (2009) suggests paying by debit card is less time consuming for many consumers because it does not require balances to regularly be repaid.

2 I argue concerns about reliability are distinct from concerns about the risk of crime, which I discuss below. 
dismissal of nine drivers that had been stealing bus fares under the previous cash-based ticketing system (Williamson, 2009, July 9). For these two reasons, I assign a low rating to the associated risk of crime for stored-value cards.

I have provided separate subjective measures of inconvenience for both POS transactions and remote payments, being those that are completed at locations away from the POS. Assuming most consumers carry cash, most small payments are completed easily using cash at the POS. The fact that consumers paid transaction fees to use the Norwegian and New Zealand debit card systems (at least when they were first introduced), however, suggests that consumers face a significant opportunity cost for transacting in cash. Accordingly, I assign cash a medium rating for its inconvenience for POS payments. Although writing a cheque is commonly thought of as inconvenient, a large amount of inconvenience will be associated with the time taken for processing a cheque transaction. Even so, paying by cheque will likely involve additional inconvenience at least because it requires carrying a chequebook. For this attribute, I have given cheque the same rating as cash. I assume most of my other instruments have an $\mathrm{M}$ rating for consumer inconvenience for POS payments. ${ }^{3}$ The two instruments I do not give an $\mathrm{M}$ rating are:

- $\quad$ stored-value cards, which I give a lower inconvenience because they do not require signature or PIN for user identification and

- $\quad$ computer-based payment instruments are currently unsuited to POS payments because of their greater need for computing hardware.

3 Although I give credit cards an M inconvenience rating, I acknowledge that using a credit card allows payment to be deferred, which means more interest can be earned on account balances. While this might be thought to mean a decrease in the inconvenience of credit card payments, I do not modify my attributes for inconvenience to reflect it because interest income will be negligible for the great majority of payments. 
Computer-based payment instruments are, however, more suited to remote payments, for which time is generally less of an issue and payments can be made when a consumer has access to a computer. I argue that credit cards are also suitable for remote payments, although to a slightly lesser extent than computer-based instruments because they generally require greater security checks. Cheque, debit card and stored-value card are less suited to remote payments, because cheques are costly in terms of time, transport and processing, ${ }^{4}$ and the two card-based instruments generally require the use of a terminal for the completion of payments, making them unsuited to remote payments. ${ }^{5}$ Although cash is not generally thought of as suitable for remote payments, I argue that this is a result of its high associated risk of crime, rather than its inconvenience, and I assign it the same rating that I give cheques for remote payments.

The literature I described in subsection 2.4.1 emphasises the importance of consumers' existing payment habits for their current behaviour. ${ }^{6}$ I have not, however, attempted to incorporate this into the table, which focuses on commonly-used payment instruments. I do return to the importance of habit when I discuss competition over attributes in subsection 5.2.2. Another factor not reflected in the table is that consumers will experience additional inconvenience from an instrument, if using it requires them to maintain an account separate to the one that absorbs their earnings. Common examples of instruments that require secondary accounts include credit cards, stored-value cards and the computer-based instrument, Paypal. I argue that the inconvenience that comes from maintaining a second account is consistent with the observation of Zinman (2009)

$4 \quad$ For the sake of simplicity, I do not reflect in my Table that transportation of cheques will be more costly for remote payments than for POS payments.

5 Although I do not change my ratings to reflect it, I note that debit cards have been issued under the schemes of Visa or MasterCard in all of my sampled countries and these cards can be used for remote payments (as well as internationally).

6 In particular, Guariglia and Loke (2004) investigate payment instrument use in 15 developed, EU and G10 countries between 1990 and 1998. They show that a key factor affecting the volume of non-cash transactions is consumer habit, as measured by the positive relationship between the transaction volume of a particular instrument and the lagged transaction volume of that instrument. 
that paying by debit card offers greater time savings for consumers because of no requirement to regularly repay balances.

I give instruments the same rating for their inconvenience to merchants because, with the exceptions of cash and cheque, I believe each instrument will result in the merchant receiving funds from transactions without significant additional difficulty. ${ }^{7}$ For different reasoning, I also assign cash and cheque a low rating: although cash payments require merchants to make arrangements to deposit the money at the merchant's bank, this sort of inconvenience has a relatively low marginal (opportunity) cost, but a higher average variable cost. That is, any one transaction does not create much additional cost for the merchant, but, taken together, a greater number of transactions made using an inconvenient payment instrument for the merchant puts the merchant to significant, additional cost. ${ }^{8}$ This would be the result of a greater number of trips to the bank or having more manual payments to input into an electronic accounting system, for example. This distinction is important because, for the purposes of my table, I place greater emphasis on the relatively low marginal cost by giving the attribute a low rating. I suggest that the low marginal cost of cash is the reason that, as I outlined in subsection 4.4.3, merchants labelled the financial costs of Germany's Geldkarte stored-value system as outrageous, in spite of market research showing these fees were lower than merchants' cost of handling cash,. I give cheques the same rating because each cheque will not require significant additional inconvenience.

In terms of financial costs, consumers will generally face fixed costs from the maintenance of an account at a financial institution. As discussed, I assume a

7 I acknowledge that electronic payment instruments might be more convenient for some merchants' accounting systems, although I do not adjust my ratings to reflect this.

$8 \quad$ This thinking may also apply to other instrument attributes, particularly the risk of crime associated with an instrument, but, for the sake of brevity, I chose not to analyse them in a similar way. 
consumer maintains one account for receiving his or her income. Payment instrument accounts secondary to that are considered additional fixed costs for those instruments. Of the payment instruments considered, credit cards and stored-value cards will commonly require customers to maintain a second account, in addition to the one used to receive wages, although some debit cards require an additional annual or semi-annual fee from consumers. By virtue of requiring a computer, computer-based payment instruments will require substantial fixed costs for access, but I assume, however, that consumers already have access to a computer and assign computer-based instruments a medium rating for consumer fixed financial costs. Consumers do not generally face a marginal financial cost for most payment instruments, although, in some jurisdictions, they incur fees for cheque and debit card use. Consumers may in fact face negative financial costs for using credit cards if award points they receive when using such cards are included. Such points only appear to make a small difference to prices, however. In 2003, as credit card interchange fees were becoming regulated, the Reserve Bank of Australia (2007, para. 95) reported that the standard credit cards of major Australian banks required consumers to spend $\mathrm{A} \$ 12,400$ to receive an $\mathrm{A} \$ 100$ voucher, a return of just $0.8 \%$.

Because my table relates to commonly used instruments, I assume that merchants require one bank account for their operations and thereby do not incur additional fixed costs from account-keeping. My historical summaries in Chapter 4 show, however, that merchants in all of my sample countries generally need to buy or rent terminals to accept debit cards and the evidence I've gathered on stored-value cards shows they generally require a different terminal to accept these, also. Merchants are often charged per-transaction fees when accepting transactions, known as MSFs. Although proportional in nature, I have assigned the highest rating to these for credit cards because such cards generally incur the highest MSFs of commonly used payment 
instruments. If there are MSFs for cash payments, these will be insignificant when a number of transactions are conducted using cash. MSFs will be low to medium for account-to-account payment instruments, such as cheque, debit card and computerbased instruments, but higher for stored-value cards. Because these require a separate account to be maintained, but are less able to charge users for it (since users will then be much less likely to use it), a payment network will have little choice, but to charge a higher MSF for a stored-value instrument.

Credit cards provide consumers with a source of short term credit and therefore offer the least constraint on liquidity of the instruments I consider. ${ }^{910}$ Because they commonly link to a consumer's bank account, the other instruments provide more liquidity than cash or stored value cards. All the instruments considered quickly provide merchants with funds, with the exception of cheques, which may take some days to clear into a merchant's bank account.

\section{Attributes of consumer-based instruments}

To consider consumer-based instruments, I believe elements of Table 5.1 are such that a merchant's attributes could be replaced with a payee's (assuming a consumer's attributes become those of a payer). Indeed, I discussed two instruments, cash and computerbased instruments, that may be used for transactions not involving merchants. Of course, competition over attributes will be quite different for consumer-based instruments and I expand on this point at the end of my next subsection.

9 In Norway and Germany, banks commonly provide accounts with short-term overdrafts accessible using a debit card. However, this is uncommon in the other countries I consider.

10 In their review of the literature, Garcia-Swartz et al (2007) refer to one particular reason for debit card use: debit cards represent a commitment device for individuals to constrain their spending. However, Zinman (2009) makes no reference to this reason for debit card use in his analysis of debit card/credit card decisions for consumers and I do not include it in my analysis, here. Nor do I adjust my analysis for the use of cash as a commitment device. 


\subsubsection{Competition Over Attributes}

As discussed in section 2.4.1, Rosen (1974) shows how a differentiated product may be thought of as having a vector of implicit or hedonic prices that describes the amount of characteristics each product has, including its final price. Users will choose the best product in accordance with their assessment of all of these characteristics and the valuation they put upon them. This large set of characteristics combines with the variety of transactions between merchants and consumers to mean that many payment instruments will exist in equilibrium. While such prices might guide consumers' and merchants' choices between these instruments, I provide additional analysis of the process by which consumers and merchants settle on an instrument to use to complete their transactions.

In subsection 2.4.1, I reviewed literature showing that consumers face significant sunk costs when they adopt new payment instruments, which is consistent with literature that shows the importance of habit to the ways consumers choose to pay. Consistent with Greif (2006), who argues that economic actors use institutions to economise on scare cognitive resources, ${ }^{11}$ I relate both the sunk costs of adoption and the importance of habit to the analytical complexities for consumers forming hedonic price estimates for each available instrument. The analytical complexities of using unfamiliar instruments might also explain the observation of Rysman (2006), who argued that consumers' favoured networks were often those most accepted by merchants. This leads to a key observation, consumers will be unable to form habits of using particular instruments unless those instruments are accepted by merchants. Arango and Taylor (2008) find

11 As well as cognitive resources, Greif (2006) also points to actors' need to economise on knowledge and attention as reasons underpinning the fundamental asymmetry; for the sake of brevity, I intend my reference to cognitive resources to include these two factors. As another underpinning, Greif discusses the value for economic actors of coordinating their actions with other actors. However, because I analyse both the two-sided and network effect elements of payment instrument decisions in this section, I believe I cover this underpinning elsewhere. 
that "aside from the initial decision to accept a payment method, merchants have little influence over the payment decisions made by consumers". ${ }^{12}$ They support this statement with analysis of the market shares of different retail payment instruments, which bear little relation to the attributes of utility for merchants. However, the statement belies the importance of merchants: while consumers will have a preferred instrument (based on their valuations of its characteristics), a merchant's customers will only be able to use it if it is accepted by the merchant.

Merchants will likely find some instruments provide a better service for the nature of their business than others. If, however, they refuse to accept a payment instrument proffered by their customers and those customers do not have a convenient alternative to hand, they risk causing their customers significant disutility. Not wishing to cause disutility is equivalent to the argument made by Rochet and Tirole (2006b) and others, that merchants internalise benefits for consumers. If disutility is caused, however, I argue it will be associated with the search costs caused by consumers finding an alternative payment instrument to complete a transaction or finding a product to purchase elsewhere. This disutility will make it more likely that consumers shop elsewhere for goods or, in the case that the merchant is a local monopoly, not buy goods. A further concern for merchants will be whether customers wishing to pay with an instrument are likely to purchase more than a merchant's average customer. For

12 Arango and Taylor studied merchants' retail payment system decisions in Canada, where the NoSurcharge Rule remains in force for Visa and MasterCard credit cards, although not for Interac debit card payments. I start by assuming merchants are unable to surcharge customers for, or otherwise steer them from, using a particular payment instrument, before I relax this assumption later in this subsection. 
these reasons, some merchants will decide to accept payment instruments that they would not otherwise accept. ${ }^{13}$

However, the range of options available to the merchant is commonly greater than just whether to accept a certain payment instrument. In some countries, merchants are able to accept certain instruments, but surcharge transactions made using them.

Alternatively, merchants may influence their customers' choice of instrument by refusing to accept transactions of less than a certain value. Since merchants likely incur higher transaction costs from surcharging, I focus on it, first, before returning to other methods merchants might influence or steer their customers' choice of payment instrument.

\section{Merchant surcharging}

Evans and Schmalensee (2005b, p. 93) suggest merchants are reluctant to surcharge transactions made with instruments not preferred because doing this raises significant transaction costs. Transaction costs associated with surcharging come from two major sources:

- $\quad$ Costs associated with the merchant effectively maintaining a separate price for some customers

- Costs associated with the merchants' customers deciding to shop elsewhere or, in the case a merchant is a local monopoly, deciding not to purchase a good.

These transaction costs explain a key observation about surcharging, when it is allowed, many merchants choose not to surcharge. For example, Bolt et al (2009) find that the $22 \%$ of Dutch merchants who surcharge do not do so for transactions greater than, on

\footnotetext{
13 For example, some merchants accept three-party credit and charge cards, such as American Express and Diners Club, in spite of their charging significantly higher MSFs than other payment instruments.
} 
average, 10 EUR. If a customer wishes to use a debit card for transactions greater than this size, they are less likely to have an alternative to hand, and a surcharge of that instrument will cause them greater disutility. For smaller transactions, however, customers are more likely to have sufficient cash for that to be a convenient alternative making merchants more likely to surcharge.

Two motivations explain why some merchants surcharge in spite of the transaction costs:

- A firm may be able to raise its profits by encouraging its customers to use its preferred payment instrument

- $\quad$ As indicated by Wright (2003), a local merchant monopolist might steer customers by setting surcharges excessively to extract rent from inframarginal cardholders.

These are not mutually exclusive. In fact, surcharging may encourage a merchant's customers to use another instrument, while extracting rent from those customers unwilling to do so, compensating merchants for the transaction costs they incur. For example, Bolt et al calculate that merchants who surcharged debit card transactions charged 23 euro cents on average, compared with an average MSF of 4-5 euro cents. That discounting cannot provide any compensation for transaction costs may be one reason explaining the observation of Kitch (1990) that it is even less common for merchants to discount for cash than it is for them to surcharge for more expensive instruments. $^{14}$

If the merchant is in a competitive environment, encouraging some customers to use its preferred instrument, as well as extracting greater rent from those consumers that do

14 Another reason for merchants' preference not to discount may be that difference in posted prices across firms adds uncertainty for consumers. 
not, may allow it to lower its prices, generally. However, the lack of stores that surcharge, when allowed to do so suggests transaction costs associated with surcharging commonly make this strategy unprofitable.

Should a merchant surcharge a payment instrument, the inconvenience consumers experience from using that instrument will likely increase significantly. ${ }^{15}$ This is reflected in evidence from Reserve Bank of Australia (2008, p. 18, citing confidential information) that the use of a surcharged payment instrument "declines substantially". 16,17 Yet, even if a consumer does not use a surcharged instrument, he or she still bears search costs associated with finding an alternative instrument or an alternative source as well as search costs relating to uncertainty about a merchant's prices. Surcharging raises transaction costs.

The No-Surcharge Rule is thus consistent with generally reducing transaction costs. ${ }^{18}$ If a No-Surcharge Rule is not imposed, merchants that decide to surcharge must decide surcharging is profitable because they recoup the additional transaction costs they face from consumers. The analysis of merchant surcharging I outlined in my historical country-by-country reviews in Chapter 4 that surcharges commonly exceed the size of MSFs, suggesting that merchants look to recoup the additional costs they face when surcharging. Such recoupment might occur because surcharging allows merchants to take advantage of different price elasticities of demand for consumers generally wishing

15 Although I focus on the inconvenience of using a surcharged instrument, an alternative representation that I do not use would be to increase a consumer's financial costs of using that instrument.

16 This is consistent with merchants only surcharging when customers have a convenient alternative to hand that is accepted and desirable to the merchant.

17 It is commonly argued that merchant surcharges discourage the use of payment instruments that have higher fees (for merchants) and, in this way, are efficiency improving (for example, see the Joint Study, 2000, p. 75). However, I argued in section 5.2 that payment instruments are differentiated products, indicating it is difficult to reach conclusions regarding efficiency, on the basis of relative financial fees, alone.

18 I refer to my discussion in section5.1 that the use of a payment instrument shows it generally reduces, rather than minimises, demand-side transaction costs. 
to pay with a particular instrument. Additionally, surcharging will raise transaction costs for consumers who search for an un-surcharged instrument with which to complete their transaction or become uncertain about merchants' prices. Accordingly, the imposition of a No-Surcharge Rule prevents merchants from imposing transaction costs on consumers and generally reduces demand-side transaction costs.

\section{Other steering methods}

As well as influencing consumers' choice of payment instrument by refusing to accept an instrument or by surcharging or discounting transactions made with one, a merchant may employ other methods to influence the payment instrument used. A relatively common one is that merchants refuse to accept a payment instrument for transactions below a certain amount. Additionally, a merchant may wish to accept one type of a scheme's instruments (such as a Visa or MasterCard credit card), but not another type (such as a Visa or MasterCard debit card). Some payment networks, however, involve rules that prevent merchants from taking this type of action, indicating that it may raise transaction costs for consumers, impeding an instrument's use. In particular, I refer to the Honour-All-Cards Rule that likely reduces consumer uncertainty, thereby reducing demand-side transaction costs.

\section{Competition over attributes of consumer-based instruments}

For consumer-based instruments, competition over attributes will occur in a different way. When not actually merchants, payees are unlikely to internalise the benefit a payer gets from using an instrument in the way that a merchant internalises a consumer's benefit. This will likely mean that payees cannot be charged higher fees than payers for using consumer-based instruments, as merchants are charged higher fees (than consumers) for using some merchant-based instruments (such as credit cards). Consistent with this argument, I described the work of Jack and Suri (2010) in section 
2.1, who reported (p. 7) that only payers pay a fee for transactions completed using the consumer-based instrument, M-PESA. Furthermore, since consumers may be either payers or payees during different transactions, it would seem more important for a payment network providing a consumer-based instrument to ensure participation, generally, rather than to ensure the participation of payers and payees, separately, as occurs for merchant-based instruments. A lack of data from my sample countries makes me unable, however, to make any strong observations about the competition that will occur over attributes for consumer-based instruments.

\subsubsection{Payment Instrument Demand and Network Effects}

I have discussed one key factor relating to demand for payment instruments that enhances the importance of network effects. ${ }^{19}$ The factor is that sunk costs of adoption incurred by consumers, as reported in the literature I described in section 2.4.1. In subsection 5.2.2, I related these costs to the importance of consumer's habit, but argue here that they will also mean that consumers observe the habits of those around them, before deciding to adopt a new instrument. Such a process will have parallels to Ching's (2008) dynamic learning process for the diffusion of generic drugs, which I discussed in subsection 2.4.1. It will mean that use of an instrument grows disproportionately faster, the greater the number of people using it. Because they influence the number of users, all of an instrument's attributes, such as its inconvenience and financial cost, will influence the extent of network effects. Aside from any learning process, however, I argued in subsection 5.2.1 that the significance of two instrument attributes will likely be reduced if merchants and consumers expect to make a higher number of transactions with an instrument. These two attributes are:

\footnotetext{
19 Consistent with Liebowitz and Margolis (1994), which I discussed in subsection 2.3.1, I use the term, network effect, to refer to the effect on the net value of an action of the number of agents taking equivalent actions.
} 
- The financial costs of an instrument for merchants and consumers that are fixed (they do not vary with the number of transactions), such as the cost of a terminal for merchants or the cost of acquiring an instrument for consumers ${ }^{20}$

- $\quad$ Concerns about reliability held by merchants and consumers, which will be most important when a payment instrument is first introduced and

I mention this characteristic of these two attributes because it points to a payment network's instrument being more useful to users, the greater the amount they expect to use it. This is a further argument that the significance of network effects will be reduced if payment networks have access to a greater number of potential users. While this argument might seem obvious, I use it in subsection 5.4.4 to describe why merchants needing multiple types of debit card terminals in the early 1980s reduced the use of debit cards at that time in the US. I also return to the argument when I analyse the decisions of organisations to participation in payment networks in subsection 5.3.1. Before I consider instrument supply decisions, however, I pay further attention to the operation of network effects in retail payment systems, outlining aspects to network effects for merchant-based, and then consumer-based instruments, before analysing their importance to complete this subsection.

\section{Network effects for merchant-based instruments}

A factor complicating the nature of network effects is that merchant-based payment instruments involve two distinct groups of users, consumers and merchants. Consumers' expectations, and therefore desire to use a payment instrument, depend on merchants' acceptance of that instrument while merchants' expectations, and therefore

\footnotetext{
20 For example, a consumer might incur fixed financial costs when opening an account to use a payment instrument. Although it is not strictly a financial cost, it seems appropriate to include the opportunity cost of a consumer's time in acquiring an instrument in this category, also.
} 
acceptance of an instrument, depend on consumers' desire to use an instrument. This creates what is commonly called the chicken and egg problem: why will consumers wish to use an instrument unless it's accepted by merchants and why will merchants wish to accept it, unless consumers wish to use it? For consumer-based instruments, the problem collapses into one of having a sufficient number of other users to make using an instrument worthwhile for any single user.

\section{Network effects for consumer-based instruments}

Although I argued in the previous subsection it was difficult to be explicit about competition over attributes for consumer-based instruments, evidence indicates that network effects are likely to be a major issue for these, also. Unlike for consumers, I have not found literature arguing that merchants face sunk costs of adoption of new payment instruments. When a consumer replaces a merchant as a payee for a consumer-based instrument, both sides using it will face sunk costs of adoption. This suggests network effects will be stronger for consumer-based than for merchant-based instruments. My lack of observations on this issue, however, makes me unable to reach any strong conclusions on the matter.

\section{The importance of network effects}

Network effects' importance, is highlighted by the difficulties experienced in all of my sample countries creating a successful stored-value card system during the 1990s. None of the pilots of the Mondex payment instrument introduced in all but one of my countries led to large-scale deployments. ${ }^{21}$ As I discussed on subsection 2.4.1, however, I believe concerns about network effects can be overstated: I mentioned one

21 The country that did not see a Mondex pilot was Germany, where the ZKA German banking association instead promoted the Geldkarte stored-value network, which it rolled out nationally in 1997. In 2005, a Geldkarte manager is quoted as saying that saying that the system had started only focusing on unattended points of sale because of the difficulties promoting it in other attended locations. 
author who blamed them for the failure of stored-value payment networks in the US while another pointed out that these networks had failed to convince consumers and merchants that they should use and accept such instruments. I provide further analysis of the importance of network effects when I compare merchant acceptance of payment instruments and their use by consumers in the next subsection.

\subsubsection{Comparing Merchant Acceptance with Consumer Habit}

To support my description of the process used to choose a merchant-based instrument and my description of relevant network effects, I analyse aspects to the introduction and the adoption of new payment instruments. The analysis indicates that, while the instrument that gets used will generally reduce demand-side transaction costs, that instrument will likely be the one that is acceptable to merchants, rather than being the most technologically advanced instrument.

\section{The introduction of new retail payment instruments}

Table 5.2 sets out the MSFs of selected new retail payment instruments, compared to the MSFs of what I judge to be the major competing instrument(s). The new instruments shown are, with one exception, selected as instruments that did not require merchants to incur significant additional fixed financial costs, such as through the purchase or rental of card terminals, before they were able to accept the instrument. ${ }^{22,23}$ I have also chosen not to show the introduction of credit cards in my table for the sake

22 This is, in effect, a simplifying assumption. As I identified in subsection 5.2.1, the fixed financial costs faced by merchants will make their desire to use a retail payment instrument dependent on their expectations of how much that instrument will be used. In order to allow my analysis to disregard such expectations, I focus on payment instruments where merchants do not face additional fixed financial costs.

23. I have not included new payment instruments introduced in Norway or the UK in the table, because I have not found sufficient evidence on the introduction of instruments meeting my table's criteria. 
of simplicity. ${ }^{24}$ An instrument provided for use with no MSF does not charge the merchant a fee, per-transaction; a fixed MSF refers to a per-transaction fee that does not change with a transaction's value while a proportional fee is proportional to value.

The exception I have made is a stored-value system, Snapper, being developed in New Zealand. I have included it because it demonstrates why a merchant might accept an instrument, in spite of the need to invest in a special terminal to do so. Additionally, I have included Snapper, but not other stored-value systems because, unlike London's Oyster card, it can be accepted by more than one type of merchant and, unlike Germany's Geldkarte card, it has a public transport application. The literature discussed in subsection 2.4.1 suggested this would help an instrument overcome relevant network effects. 
Table 5.2. Unregulated MSFs of Selected Newly-Introduced and Competing Payment Instruments for POS Transactions

\begin{tabular}{|c|c|c|c|c|c|}
\hline Country & $\begin{array}{c}\text { New } \\
\text { Payment } \\
\text { Instrument }\end{array}$ & $\begin{array}{l}\text { Year First } \\
\text { Introduced }\end{array}$ & $\begin{array}{c}\text { New } \\
\text { Instrument's } \\
\text { MSF }\end{array}$ & $\begin{array}{c}\text { Major } \\
\text { Competing } \\
\text { Instrument }\end{array}$ & $\begin{array}{c}\text { Competing } \\
\text { Instrument's } \\
\text { MSF }\end{array}$ \\
\hline Australia & $\begin{array}{c}\text { Scheme- } \\
\text { Based Debit } \\
\text { Card }\end{array}$ & 1982 & Proportional & $\begin{array}{c}\text { Cash } \\
\text { (Credit Card) }\end{array}$ & $\begin{array}{c}\text { None } \\
\text { (Proportional) }\end{array}$ \\
\hline Canada & $\begin{array}{c}\text { Scheme- } \\
\text { Based Debit } \\
\text { Card }\end{array}$ & 2008 & Fixed & $\begin{array}{c}\text { Interac Debit } \\
\text { Card }\end{array}$ & Fixed \\
\hline Germany & $\begin{array}{l}\text { Scheme- } \\
\text { Based Debit } \\
\text { Card }^{(1)}\end{array}$ & 2007 & Proportional & $\begin{array}{l}\text { Electronic } \\
\text { Cash }\end{array}$ & Proportional \\
\hline \multirow{2}{*}{$\begin{array}{l}\text { New } \\
\text { Zealand }\end{array}$} & $\begin{array}{c}\text { Scheme- } \\
\text { Based Debit } \\
\text { Card }\end{array}$ & 2006 & None & $\begin{array}{c}\text { EFTPOS Debit } \\
\text { Card }\end{array}$ & None \\
\hline & $\begin{array}{l}\text { Stored-Value } \\
\quad \text { Card }^{(1)}\end{array}$ & 2008 & Proportional & $\begin{array}{c}\text { EFTPOS Debit } \\
\text { Card }\end{array}$ & None \\
\hline $\begin{array}{l}\text { United } \\
\text { States }\end{array}$ & $\begin{array}{c}\text { Scheme- } \\
\text { Based Debit } \\
\text { Card }\end{array}$ & $\begin{array}{c}\text { Mid- } \\
\text { 1990s }\end{array}$ & Proportional & $\begin{array}{c}\text { Cash } \\
\text { (Credit Card) }\end{array}$ & $\begin{array}{c}\text { None } \\
\text { (Proportional) }\end{array}$ \\
\hline
\end{tabular}

(1) While scheme-based debit cards, in the form of co-badged Electronic Cash/Maestro cards were already available in Germany, Maestro cards became available in this year that did not use Electronic Cash for the completion of transactions within Germany.

(2) Contrary to my assumption discussed above, merchants do incur some additional fixed financial costs to accept Snapper stored-value card transactions, in the form of an additional terminal. I discuss this further below.

(3) Although scheme-based debit cards were first developed during the 1970s, it wasn't until this time that they were significantly promoted by the Visa and MasterCard credit card schemes.

Unless a new instrument represents a substantial improvement for merchants over the major competing instrument, they are more likely to refuse to accept the new instrument if it charges a significantly higher MSF than the incumbent instrument. In the three countries, Canada, Germany and New Zealand, where networks introduced a schemebased debit card to compete with each country's domestic debit card system, they did 
not charge merchants MSFs that were different to MSFs charged by the domestic system. This is consistent with my characterisation given that, as I described in subsection 5.2.1, scheme-based debit cards do not represent a substantial improvement for consumers and merchants over domestic debit cards for POS transactions. When scheme debit cards were introduced in Australia and the US, however, they did represent a substantial improvement over one major competing retail payment system, cash, but less so over the other, credit cards. As my characterisation predicts, the MSFs of these two instruments matched those of credit cards and were proportional, in nature.

Because it requires neither a PIN nor a signature, New Zealand's Snapper stored-value card is significantly more convenient for merchants who benefit from transactions being processed more rapidly than can be achieved with the PIN-based incumbent payment instrument, the EFTPOS debit card. Furthermore, Snapper has a lower associated risk of crime than cash by virtue of being more traceable, which is important for merchants who operate in cash rich environments, but rely on employees to operate as their agents. For these reasons, I argue some merchants are willing to accept it, in spite of incurring both fixed costs and proportional fees in order to do so.

Although I have not included it in my table, it is instructive to consider Germany's Geldkarte stored-value system. As I discuss in subsection 4.4.3, although 67 million Geldkarte cards had been issued by 2001 (following the system's nationwide introduction in 1997), only about $2-3 \%$ of these were held by active card users. ${ }^{25}$ The importance of merchant acceptance was indicated when a manager at the payment network operator admitted in 2005 that the network had ended promoting acceptance outside of unattended retail because it had found such promotion "very difficult". This

25 The Geldkarte system did not receive significant promotion from the pillar of the banking system with arguably the strongest profit motive, the commercial banks (the other pillars being the cooperative and the public banks). 
further indicates the importance of having merchants accept an instrument, but also to have consumers desire to use it.

Table 5.2 deals with all successfully introduced payment instruments I have identified that, with the exception of Snapper, did not require merchants to incur fixed costs before accepting them. That is, I have not identified any successfully introduced instruments without such costs that did not compare favourably for merchants with the incumbent instrument. In order to test the pricing for merchants of instruments that do require fixed costs, I turn to usage of debit cards.

\section{Debit card pricing for merchants}

Consumers in my sample countries were using similar payment instruments when debit cards were introduced (that is, cash supplemented by cheques, credit cards and, in two countries, giros). Following the development of the POS terminal, debit cards represented a major improvement over existing payment instruments because it allowed consumers to directly access the accounts that absorbed their earnings. ${ }^{26}$ I analyse relevant prices, being the per-transaction fees charged to consumers and merchants, and differences between countries in the adoption of debit cards. In my country-by-country summaries in Chapter 4, I reported that merchants in all of my sample countries are generally required to purchase or rent POS terminals in order to accept payments by debit card.

Table 5.3 summarises information on relevant prices for major debit card systems in the countries studied, as well as the usage of debit cards in a country, generally. Where I have reported significant trends in fees, these are given in brackets. I have also provided the year major systems were introduced.

26 Although credit cards were developed before debit cards, their use requires consumers to open an account generally additional to the one that absorbs their earnings. 
Table 5.3. Pricing and Usage of Major Debit Card Systems

\begin{tabular}{|c|c|c|c|c|c|}
\hline \multirow[t]{2}{*}{ Country } & \multirow{2}{*}{$\begin{array}{c}\text { Names of } \\
\text { Major Debit } \\
\text { Card } \\
\text { Networks }\end{array}$} & \multirow[t]{2}{*}{$\begin{array}{l}\text { Year } \\
\text { System } \\
\text { Established }\end{array}$} & \multicolumn{2}{|c|}{$\begin{array}{c}\text { Nature of Per-transaction } \\
\text { Fees of Major Networks } \\
\text { Faced By: }^{(1)}\end{array}$} & \multirow{2}{*}{$\begin{array}{c}\text { Average } \\
\text { Number of } \\
\text { Transactions } \\
\text { Per Capita, } \\
\text { 2008 }^{(2)}\end{array}$} \\
\hline & & & Merchants & Consumers & \\
\hline Australia & EFTPOS & $1985^{(3)}$ & $\begin{array}{l}\text { Fixed } \\
\text { (increasing) }\end{array}$ & Some fixed & 81 \\
\hline Canada & Interac & $1994^{(4)}$ & Fixed & Some fixed & 111 \\
\hline Germany & Ec Cash & $1990^{(5)}$ & Proportional & None & 23 \\
\hline $\begin{array}{l}\text { New } \\
\text { Zealand }\end{array}$ & EFTPOS & $1989^{(6)}$ & None & $\begin{array}{l}\text { Some fixed } \\
\text { (decreasing) }\end{array}$ & 181 \\
\hline Norway & Bank-Axept & $1991^{(7)}$ & $\begin{array}{l}\text { None } \\
\text { significant }\end{array}$ & $\begin{array}{l}\text { Fixed } \\
\text { (decreasing) }\end{array}$ & $191^{(8)}$ \\
\hline $\begin{array}{l}\text { United } \\
\text { Kingdom }\end{array}$ & $\begin{array}{l}\text { Visa Debit, } \\
\text { Maestro and } \\
\text { Solo }\end{array}$ & $1986-88^{(9)}$ & Fixed & None & 89 \\
\hline $\begin{array}{l}\text { United } \\
\text { States }\end{array}$ & $\begin{array}{l}\text { MasterCard } \\
\text { and Visa }\end{array}$ & $\begin{array}{c}\text { Mid- } \\
1990 \mathrm{~s}^{(10)}\end{array}$ & $\begin{array}{l}\text { Proportional } \\
\text { (increasing) }\end{array}$ & $\begin{array}{l}\text { Commonly } \\
\text { none }\end{array}$ & 113 \\
\hline
\end{tabular}

(1) Column refers to the current per-transaction fees for POS transactions made using major systems. None means no per-transaction fees are charged. Fixed refers to per-transaction fees that do not change in size with the size of the transaction. Some fixed refers to fees that, depending on a consumer's account, are generally either zero or fixed. Proportional refers to fees that are proportional to the transaction's value. The labels in brackets, increasing and decreasing, refer to general trends that I reported in Chapter 4 in the levels of fees charged

(2) Figures include debit card transactions completed over all networks, rather than just major ones

(3) Year from which contracts between EFTPOS networks were negotiated, allowing interconnection

(4) Year in which Interac debit card network rolled out nationally

(5) Year in which agreement reached between banks for the national roll-out

(6) Year in which agreement reached between banks creating EFTPOS network of Electronic Transaction Services Limited

(7) Year in which agreement reached between banks creating BankAxept

(8) As I discuss in subsection 4.6.5, this figure does not include transactions made with Norwegian cards in countries other than Norway, nor transactions on nonBankAxept debit cards

(9) Years in which major banks introduced their own debit card instruments, Visa and Switch debit cards

(10) Approximate date that Visa and MasterCard started promoting their Visa Check and MasterMoney offline debit cards. 
In subsection 4.4.5, I outlined my inability to fully explain Germany's low use of debit (and credit) cards, which remains important here. Ignoring Germany, Table 5.3 clearly shows that, in the two countries with the most well-used debit card systems, New Zealand and Norway, merchants are not charged significant MSFs by the major debit card system. The table shows little, if any, relationship between the year of a system's introduction and the extent of its adoption. Merchants' per-transaction fees are important to the adoption of debit cards because, once merchants have incurred the fixed cost of a debit card terminal, they will likely accept transactions of any amount. In the two countries where merchants are not charged significant fees, consumers show a preference to use their debit cards in spite of facing fixed per-transaction fees. ${ }^{27}$ When merchants are charged significant per-transaction fees for debit cards, as happens in the other five countries in my sample, they are less willing to accept smaller debit card transactions because, I argue, their customers will often have a an instrument to hand that is cheaper for them to accept, cash. As with my analysis of the introduction of new instruments, it is the acceptance of instruments by merchants that appears key to the development of retail payment systems.

The focus of Table 5.3 on just one payment instrument, the debit card, makes it difficult to draw conclusions beyond what I have already discussed. Norway's high use of debit cards, relative to New Zealand's, will be influenced by the greater use of bank account overdrafts (accessible using just a debit card), rather than credit cards, as a source of short-term consumer credit. I have not found additional information to assess the use of credit cards against bank account overdrafts in New Zealand.

27 As I discussed in subsection 5.2.1, I believe this fact indicates that consumers face significant inconvenience when completing transactions in cash. 


\section{The evolution of retail payment systems based on demand by consumers and merchants}

My analysis has shown that many payment instruments will exist in equilibrium, but that competition will occur between them to generally reduce demand-side transaction

costs. It has also indicated that a key way for instruments to reduce these costs is to first make a new payment instrument acceptable to merchants. I provide further reasoning for why I believe this is the case using an example of a payment network providing a merchant-based instrument and receiving fees from either consumers or merchants. The network needs merchants to incur fixed costs, such as the purchase or rental of a terminal, before they can accept its instrument and, if acceptance of the instrument does not offer significant benefits to merchants over alternative instruments (such as by increasing sales or allowing faster transaction completion), merchants will be less keen on a new instrument. If merchants are charged in any significant way for using the instrument, fewer incur fixed costs needed to accept it. While consumers may be more willing to use an instrument if they go uncharged, the lower level of acceptance by merchants will reduce the chances consumers have to use debit cards and develop new payment habits. In this way, acceptance precedes the forming of habits. My description is obviously static, but it provides a way of understanding a dynamic process. If merchants find a payment instrument attractive, more will incur the fixed costs necessary to accept it. This will lead to more consumers forming the habit of paying with an instrument, which will increase the pressure for other merchants to also accept an instrument. I have not seen merchants' acceptance of new instruments emphasised in this way, in the literature before.

While my conclusion about merchant acceptance preceding customer habit looks obvious, it supports my characterisation of competition over instrument attributes and 
explains why instruments based on technological improvements will have problems overcoming network effects if they do not confer benefits on merchants and merchants do not wish to accept them. However, even if merchants accept an instrument, consumers need a reason to use it and form the habit of using it. The essence of the network effects problem will remain: how do payment networks get enough merchants to accept an instrument, in order to get enough consumers to form the habit of using it to get still more merchants to accept it? Payment network choices, including pricing and interchange fee decisions and the imposition of the No-Surcharge Rule will be part of the answer, but, to properly answer the question, I investigate the supply of payment instruments by networks in the next section.

\subsection{Supply of Instruments by Payment Networks}

In this section, I analyse incentives faced by payment networks as they provide instruments to users. A profit-maximising network will attempt to maximise the difference between the fees it gets paid by users of its instrument and the costs it incurs in providing that instrument. In subsection 5.3.1, I begin my analysis of instrument supply by introducing the operations of a payment network and describing how network effects create an incentive for profit-seeking payment networks to increase their participation. In subsection 5.3.2, I analyse opportunities for a payment network to provide a new payment instrument, arguing that, in workably competitive conditions, a profit-seeking payment network will provide an instrument that gets used while it at least recoups its costs of supply from fees paid by users. I go on to argue that this indicates a process of payment networks adapting to changing circumstances. In subsection 5.3.3, I analyse the role of (potential) inter-network competition, arguing that a payment network will likely experience greater participation if, ceteris paribus, it offers an instrument that generally reduces demand-side transaction costs to a greater 
degree than competing networks' instruments and provides it with lower costs of supply. I argue that, since network effects raise the incentive for profit-seeking payment networks to increase their participation, (potential) inter-network competition promotes dynamic efficiency. I summarise my findings on payment instrument supply in subsection 5.3.4.

As well as production costs, costs relevant to a payment network include transaction costs incurred during the production of, and the provision of services for, a network's instrument. Milgrom and Roberts (1992) argue that transaction costs are only sometimes distinct from production costs, suggesting to me that an approach of defining production costs that includes transaction costs would create confusion for readers. For this reason, I define the costs of supply below.

\section{Transaction costs and the costs of supply}

In the preceding section, I discuss the relevance of demand-side transaction costs to the demand for payment instruments. While it might be tempting to define supply-side transaction costs as transaction costs occurring within a payment network, the literature I described in subsection 2.3.1 argues that transaction costs are not always distinct from production costs. I believe this is mainly an issue when transaction costs relate to the transaction at hand. Transaction costs for transactions completed during earlier stages of the production process still need to be considered, however, because they will likely raise the price members of a payment network are willing to charge instrument users. Accordingly, I define the costs of supply of a payment instrument to include the production costs a payment network incurs in offering an instrument to users and the transaction costs incurred between members of a payment network in the course of producing and servicing that instrument. 


\subsubsection{Payment Networks: Operations and Participation}

Baxter (1983) gives an account of the development in the US of four-party payment networks for the processing of cheques during the previous 150 years. Banks that otherwise competed might participate in the same payment network by accepting each other's cheques. A transaction involving such a network would see a consumer using a cheque to complete his or her transaction with a merchant. After collecting the cheque from the merchant, the merchant's bank (the acquirer) would pass the cheque on to the consumer's bank (the issuer) for settlement of the transaction. To fund an instrument's costs of supply, a payment network will collect fees from instrument users.

In subsection 5.2.3, I argued that network effects mean the use of an instrument grows disproportionately faster, the greater the number of people using it. Having more banks participating in a cheque-based payment network will generally mean a greater number of consumers proffer the network's cheques and a greater number of merchants accept them. In my discussion of network effects, I also demonstrated two particular instrument attributes that could be improved (to encourage greater instrument use) through greater participation in a payment network, those attributes being concerns about an instrument's reliability and the fixed financial cost of an instrument's use. I argue a network reaching a greater size will find it easier to convince potential users of an instrument that they are likely to conduct a greater number of transactions using it, making them more accepting of concerns about reliability and more willing to incur fixed costs before using it. Greater participation thus contributes to payment networks overcoming network effects, allowing them to raise profits by increasing their usage fees (because greater participation means cheques will be used more widely, generally reducing demand-side transaction costs, ceteris paribus) A profit-seeking payment network thus has an incentive to increase participation because it reduces the significance of the network effects faced by users of its instrument. 
An additional concern for payment networks is of course costs and cost minimisation does have some importance. For example, Baxter (1983) describes the process banks developed (prior to the intervention of the Federal Reserve) to provide services for transactions made with their cheques. Banks would set cheque processing fees collectively, which Baxter argues was efficiency-enhancing because it reduces costs associated with the negotiation of such fees. It is, however, the costs of supply that are relevant to payment networks and these include transaction costs. In work I described in subsection 2.3.1, Milgrom and Roberts (1992) argued that it was not obvious efficient organisations would minimise transaction costs, suggesting instead that sufficient competition is required before minimisation of such costs can be assumed. For this reason, I return to analysis of payment networks' costs when I consider the role of internetwork competition in subsection 5.3.3.

\subsubsection{Profitable Opportunities and Institutional Adaption}

A significant new technology for retail payment systems was the payment card, which increased the range of instruments that could be offered by payment networks and the range of organisations able to offer instruments that generally reduced demand-side transaction costs. Diners Club, the first mass marketed payment card in the US, was not offered by a bank, but by a company whose business was primarily focused on the card - by itself, it coordinated both the issuing of cards to consumers and acquiring transactions from merchants. I argue that Diners Club introduced its card because it perceived there was a profitable opportunity to offer an instrument that generally reduced demand-side transaction costs while recouping its costs of supply. Given banks' role in providing customers with funds and that cards accessing funds held at a bank will likely be an asset specific to that bank, transaction cost analysis indicates banks' interest in payment cards. In addition, Diners Club competed as a payment instrument with banks' cheques. Banks' payment cards offered consumers a line of 
credit and became called credit cards. Consistent with a preference for institutions that had previously been used - the fundamental asymmetry described by Greif (2006) banks created networks for their credit cards similar to networks used to process cheques. These early efforts at cooperation eventually developed into the national credit card brands, Visa and MasterCard, with both organisations developing a corporate structure based on a multi-party membership corporation.

The early stages of the introduction of payment cards demonstrate a dynamic process of institutional adaption as has been described by Greif with parameters useful to Greif's framework being those that influence the ability of a payment network to increase profit by offering an instrument that gets used because it generally reduces demand-side transaction costs while the network at least recoups its costs of supply from fees paid by users. ${ }^{28}$ I caveat this comment by specifying that it applies to payment networks in workably competitive conditions. I add this caveat to rule out the possibility of a monopolist failing to introduce an instrument because it would cannibalise profits from existing instruments.

Another example of institutional adaption is the stored-value payment instrument, Snapper, created by a private provider of bus services in New Zealand. Literature I described in subsection 2.4.1 indicated that a public transport application represented a way for stored-value payment networks to overcome network effects. In subsection 5.2.4, I argued that, in spite of transactions made using Snapper incurring significant MSFs (relative to what I label to be the incumbent payment instrument, the EFTPOS debit card), a stored-value instrument was acceptable to merchants because it allowed faster processing of transactions than PIN-based EFTPOS card payments as well as 
having a lower associated risk of crime than cash. Snapper's bus company owner saw a profitable opportunity to provide an instrument that benefited consumers by reducing their demand-side transaction costs.

As well as demonstrating an adaptive, profit-maximising process, the above examples demonstrate the relevant private objective for profit-seeking payment networks: in workably competitive conditions, a network will wish to increase its profits by offering an instrument that generally reduces demand-side transaction costs while at least recouping its costs of supply. This indicates a dynamic question relevant to my thesis: if opportunities appear to exist for profit-seeking payment networks to generate profit while generally reducing demand-side transaction costs, why are these not taken? The question points to the role of (potential) inter-network competition in encouraging dynamic efficiency, which is what I now turn to.

\subsubsection{Inter-Network Competition and Dynamic Efficiency}

In subsection 5.3.1, I described how network effects raise the incentive for profitseeking payment networks to increase participation. To analyse organisations' decisions about participation, I use the framework of institutional change provided by Grief (2006), which I described in section 2.3. Based on it, I find that (potential) internetwork competition promotes dynamic efficiency. Specifically, I find that, in the presence of such competition, a profit-seeking payment network will likely experience greater participation if, ceteris paribus, it offers an instrument that generally reduces demand-side transaction costs to a greater degree than competing networks' instruments and provides it at lower costs of supply.

Greif (2006) describes a process of institutional change that is based on individuals deciding how to behave, taking the behaviour of others as a given. Institutions will be self-enforcing if, given a set of parameters and the behaviour of others, individuals use 
behaviour consistent with those institutions as they decide how to behave. Taking Greif's framework and using the profit-seeking behaviour of payment networks that I argued occurs in the previous subsection, I analyse the role of (potential) inter-network competition in instrument supply decisions made by payment networks. I find that inter-network competition means a profit-seeking payment network that does not reduce demand-side transaction costs to a greater degree than competing networks' instruments and/or does not provide them with lower costs of supply will be self-enforcing under a smaller set of parameters than it will without inter-network competition. ${ }^{29}$ I demonstrate this point with two examples of retail payment system development in New Zealand and one of development in the US.

My first example is the creation of the New Zealand debit card payment system, EFTPOS, in a series of events that I describe in detail in subsection 4.5.3. In New Zealand, there were initially two separate EFTPOS networks, one known as Cashline created by the trustee savings banks and the other known as Quicksmart created by the trading bank-owned joint-venture, Databank. ${ }^{30}$ A crisis for the stability of EFTPOS followed the 1988 decision of two (former) trading banks, ANZ and BNZ, to end their involvement with the Quicksmart network. The decision came as New Zealand's banks faced financial pressure following the 1987 sharemarket crash and I interpret it to indicate that the banks no longer felt able to recoup the costs associated with Databank's EFTPOS network while still generally reducing users' demand-side transaction costs. In events I described in subsection 4.5.3, the two other owners of Databank, Westpac and National Bank, purchased the assets of Quicksmart, renamed the network Handypoint, and decided to operate it without MSFs in order to compete with the Cashline

\footnotetext{
29 I assume that a profit-seeking network will not supply an instrument unless it recoups its costs.

30 As I discuss in subsection 4.5.2, legislation passed in 1986 removed the regulatory distinctions between trading banks and trustee savings banks, allowing all who met certain criteria to become entities known as, registered banks.
} 
network. I argue this indicates that Westpac and National Bank saw this development as the most profitable way to generally reduce demand-side transaction costs.

Furthermore, I argued in section 5.2 that pricing a debit card in this way made the instrument more effective at generally reducing demand-side transaction costs. Successive events, each of which I also described in subsection 4.5.3, reinforced the institution of not charging MSFs for POS debit card transactions, further demonstrating that pricing debit cards in this way generally reduced demand-side transaction costs to a greater degree than potentially competing networks' instruments :

- the owners of the Cashline network merged it with Handy-point, while adopting a similar approach to MSFs as Handy-point, to form the jointly-owned company, ETSL (Electronic Transaction Services Limited) in 1989

- $\quad$ BNZ joined ETSL and ANZ set up a competing switch that offered merchants EFTPOS services without their incurring MSFs

- $\quad$ ANZ Bank attempted to charge MSFs for EFTPOS transactions in 1998, but was forced to end the practice after it lost significant merchant account business to other banks and

- Westpac introduced a Visa Debit Card, which did not charge MSFs for transactions at the POS, in 2006.

In my second New Zealand example, another bank, ASB, was frustrated at what it felt were poor cheque-clearing services being provided by the incumbent processing company, Databank. I argue that this frustration suggests Databank's cheque-clearing network did not reduce demand-side transaction costs to a greater degree than potentially competing networks' instruments. As I described in subsection 4.5.3, ASB responded to this situation in 1989 by creating what was described to me as a "stalking 
horse", an alternative payment network, Payment Clearing Limited. That action resulted in the four banks that owned the incumbent network improving it by providing for faster cheque processing. Databank's owners also invited other banks to become joint-owners of the Databank inter-bank transfer processing assets, which eventually became the joint-venture ISL (Interchange and Settlement Limited). I argue that this action would have reduced expectations of the costs of supply of instruments that used ISL. The institution of inclusive development of inter-bank networks was reinforced in 2010 when New Zealand's banks created a payment network to replace ISL, Payments NZ Limited.

Further evidence of the effect of inter-network competition on an instrument's costs of supply comes from analysis of the development of credit card payment networks in the US, which I described in subsection 4.8.1. Also consistent with Greif's fundamental asymmetry, Visa and MasterCard introduced structures to make use of the institutional approach to pricing developed by the Diner's Club three-party payment network - the collection of the majority of an instrument's fees from merchants. To properly approximate such an approach in a four-party network, Visa and MasterCard used an interchange fee to pass at least a portion of the MSF the acquirer collected from the merchant to the issuer. In subsection 2.4.2, I referred to literature, specifically Evans and Schmalensee (2005b), that indicated that these payment networks eventually coordinated to set interchange fees multilaterally in order to reduce their costs of supply. I argue that inter-network competition for issuers and acquirers between Visa and MasterCard caused them to adopt this approach. Evidence also shows Visa's predecessor organisation eventually adopted a corporate structure similar to MasterCard's, a multi-party membership corporation, in an effort to minimise the costs 
of supply for issuers of its instrument. ${ }^{31}$ The Visa and MasterCard schemes, including their institutions of interchange fees and corporate structures, were used repeatedly as banks introduced payment cards across the globe. The institutions allowed banks and other financial institutions to introduce payment cards to countries without needing to coordinate operations with other organisations, avoiding associated costs of supply. In support of this, I observe that the first banks to introduce credit cards in New Zealand and the UK were able to do so without cooperating with other banks in their countries. ${ }^{32}$ Rather than this observation showing cooperation is not important, I argue it shows banks in New Zealand and the UK effectively showed merchants and consumers they were cooperating with all of the other issuers and acquirers of the scheme of card they introduced.

\subsubsection{Summarising Instrument Supply by Payment Networks}

In this section, I introduced the concept of a payment network, outlining how it likely benefits from greater participation. I argued that the relevant private objective for a payment network: in workably competitive conditions, can it increase its profits by offering a new instrument that generally reduces demand-side transaction costs while at least recouping its costs of supply? I used this objective to suggest a process of institutional adaption for profit-seeking payment networks. I also demonstrated that, by influencing which institutions are self-enforcing, inter-network competition raises the incentive for a profit-seeking payment network to offer an instrument that generally

31 Visa's development started when a Californian bank, Bank of America, started licensing its payment card, BankAmericard, for it to be issued by other banks. Those other banks were, however, uncomfortable about issuing what was seen as Bank of America's card until the card's operations were taken over by a separate organization, National BankAmeriCard Inc. in 1970, which later became Visa.

32 In my country-by-country summaries in Chapter 4, I observed a greater amount of cooperation between banks in Australia, Canada, Germany and the US when credit cards were first introduced. I have not found sufficient information to assess experiences in Norway. In section 5.4, I argue that cooperation between banks in Australia and Germany was an outcome of the banking environments, specifically the state of inter-network competition, that existed in those places at the time of the introduction of credit cards. 
reduces demand-side transaction costs to a greater degree than competing networks' instruments and provide it with lower costs of supply. In this way, (potential) internetwork competition increases dynamic efficiency.

Although I have demonstrated these incentives, I have not yet explained the obvious differences that exist between countries' adoption of two payment instruments, debit cards and credit cards, which I observed in Figure 1.1. To better explain these differences, I analyse the role of government in retail payment systems in the next section.

\subsection{Retail Payment Systems and Government}

Until this point, I have analysed individuals' and organisations' dynamic attempts to solve maximisation problems (such as profit or utility) subject to external constraints. ${ }^{33}$ In this section, I add to my analysis, the role and effect of external constraints imposed by governments on retail payment systems. In subsection 5.4.1, I analyse aspects of the roles of government relevant to retail payment systems, a key role being the protection of property rights and the enforcement of contracts, but another important one being the restrictions governments impose on the freedom of contract for payment networks. In this section, I argue that restrictions on the freedom of contract of payment networks that prevent the trading of property rights risk reducing instrument demand or supply, harming dynamic efficiency.

In subsection 5.4.2, I discuss examples of the effects of these restrictions on instrument demand, arguing that they will reduce demand if the instrument that would have been used no longer generally reduces demand-side transaction costs. In order to clarify that

\footnotetext{
33 I reiterate that, while any individual will take the behaviour of others as external to their own decisions about how to behave, such behaviour will not be external to the framework of institutional change that I use in this thesis.
} 
these restrictions only risk reducing demand, I include in my discussion one example of a significant restriction on a payment network's freedom of contract that prevented the trading of property rights, but I argue has not reduced instrument demand.

In subsection 5.4.3, I introduce discussion of examples of restrictions affecting instrument supply by payment networks. I argue that restrictions on the freedom of contract of payment networks that prevent the trading of property rights risk reducing supply in two ways. In subsection 5.4.4, I investigate the first, considering examples of restrictions' effects on institutional adaption of profit-seeking payment networks. In subsection 5.4.5, I investigate the second, considering examples of restrictions' effect on inter-network competition. To clarify that restrictions on the freedom of contract of payment networks only risk reducing supply, I include in subsection 5.4.5 discussion of an example of a significant potential restriction on a payment network's freedom of contract that may have prevented the trading of property rights, but that did not likely reduce instrument supply.

Finally, I summarise the effects of government on retail payment systems in subsection 5.4.6.

\subsubsection{The Role of Government}

In Table 1.1, I summarised the extent of the protection of property rights in my sample countries. In section 5.2, I argued that their relatively strong protection in each country was a reason to not further analyse policing and enforcement costs as a source of (demand-side) transaction costs. That argument points to a fundamental role for governments in retail payment systems: protection of property rights and enforcement 
of contracts. ${ }^{34}$ I argue that fully protecting property right extends to the distinct activity of enforcing of contracts, referring to literature I discussed in subsection 2.3.1 that argues contracts underpin the transfer of property rights. If the role of protecting property rights and enforcing contracts is not adequately performed, the demand-side transaction costs associated with using recently-developed payment instruments would rise substantially and consumers and merchants would be more likely to use instruments arguably less reliant on the enforcement of contracts, such as cash.

Literature I described in subsection 2.4.3 suggests another role of government important to retail payment systems. Both Deungoue (2008) and Mann (2002) find government regulations and restrictions affect payment instrument adoption. I further analyse restrictions, acknowledging that many restrictions on payment networks' freedom of contract are likely to be beneficial for retail payment system development, for example, those that protect property rights. A smaller number of restrictions on the freedom of contract will, however, prevent the trading of property rights by restricting certain organisations from performing certain activities and not allowing those organisations to purchase the right to perform such activities. Examples of such restrictions include preventing NBFIs from issuing cheques or preventing payment networks from including the No-Surcharge Rule in their credit card acquiring contracts with merchants. I argue that these restrictions risk affecting the demand and/or the supply of payment instruments.

\section{A standard for assessment of government actions - dynamic efficiency}

In section 2.3, I described the work of Evans and Hahn (2010), who recommend that the objective of the regulation of telecommunications should be to maximise dynamic

34 Although my sample countries have a strong general protection of property rights, I argue specific examples exist when governments failed to protect the property rights of payment networks. I discuss these examples in subsection 5.4.4. 
efficiency. I follow this recommendation, analysing the effects of government regulation on payment networks' dynamic attempts to offer payment instruments that generally reduce demand-side transaction costs. In accordance with the value maximisation principle of Milgrom and Roberts (1992), my standard is a total welfare standard, one that was recommended as the appropriate standard for competition policy by Motta (2004) - it gives no weight to government efforts to redistribute rents relating to payment instruments. ${ }^{35}$

\subsubsection{Restrictions Affecting Payment Instrument Demand}

In the majority of my sample countries, restrictions exist over contracts governing the use of certain payment instruments. Indeed, governments and government authorities have directly regulated such contracts in Australia, Canada, New Zealand and the UK. Additionally, the US judicial system, applying law that had been introduced by the Federal Government, ended two aspects of Visa and MasterCard's payment networks, the Honour-All-Cards Rule and by-laws preventing their issuers from also issuing American Express and Discover cards. ${ }^{36}$ In the presence of inter-network competition, I expect payment network operations to generally reduce demand-side transaction costs. My presumption is that intervention in payment network operations will generally raise such costs, diminishing the dynamic efficiency of payment networks. Nevertheless, I analyse each of these cases below.

\section{Australia}

Starting in 2003, the RBA made a number of interventions in the operations of retail payment systems. While these interventions have had a large number of effects, I focus

\footnotetext{
35 As I discussed in subsection 2.3.1, I assume that there are no wealth effects in the operation of retail payment systems.

36 The Honour-All-Cards Rule was ended through an out-of-court settlement in 2001 and the US District Court found the by-laws in breach of the Sherman Act in 2001.
} 
here on their effect on demand-side transaction costs. Given payment networks have an incentive to I cited evidence in subsection 4.1.4 that issuers recovered $30-40 \%$ of interchange revenue lost because of the RBA's reforms by increasing fees to cardholders. Consistent with my conclusion that the No-Surcharge Rule generally reduces demand-side transaction costs, I also cited evidence showing that the surcharges chosen by merchants often exceed the marginal cost of accepting instruments. While I have found no evidence clearly showing the effects of the RBA's removal of the Honour-All-Cards Rule, I note that the RBA expressly intended to remove the Rule because it believed it gave a competitive advantage to Visa Debit over Australia's EFTPOS system. I interpret the phrase, competitive advantage, to mean the Rule generally reduced demand-side transaction cost and therefore I conclude that its removal will have likely harmed dynamic efficiency.

\section{Canada}

In subsection 4.2.1, I described a remedial order that was approved in 1996 following an inquiry into the operations of the Canadian Interac debit card payment network. That order required that merchants be allowed to surcharge Interac transactions. What little evidence I have found of merchants surcharging Interac transactions following the remedial order suggests that surcharges generally exceed the size of MSFs.

\section{New Zealand}

In October 2009, New Zealand's competition regulator, the Commerce Commission, announced it had reached a settlement with New Zealand's banks and Visa and MasterCard. The settlements, which I described in subsection 4.5.4, required banks to lower average interchange fees, offer retailers unbundled, unblended MSFs and allow retailers to surcharge for credit card transactions. I have found no evidence of the effect, in New Zealand, of lowering interchange fees or unblending MSFs for retailers. 
I did, however, find a press release made by the Commission in January 2010 that indicated its discomfort with the level of surcharges being applied by some retailers and I believe it is consistent with my explanation that the No-Surcharge Rule in fact generally reduces demand-side transaction costs.

\section{The United Kingdom}

I described evidence in subsection 4.7.4 that UK credit card payment networks were prevented from using the No-Surcharge Rule by Government Order in 1991. I have little evidence of the extent of surcharging in the UK, except that a complaint was made to the UK regulator, the Office of Fair Trading, that surcharges were generally higher than MSFs by the consumer group, Which?, in early 2011.

\section{The United States}

In the US, an out-of-court settlement reached in 2001 ended Visa and MasterCard's use of the Honour-All-Cards Rule, which had required merchants that accepted the scheme's credit cards also accept their debit cards. In section 2.4.2, I described the work of Rochet and Tirole (2008), which indicated that, before its removal, the Rule performed a socially-beneficial rebalancing effect on the interchange fees.

Additionally, I argued in section 5.2.2 that my analysis indicates the Rule reduces consumer uncertainty and its removal would likely raise demand-side transaction costs. A 2001 US court decision, which was upheld in appeals that ended in 2004, allowed US banks to issue any combination of Visa, MasterCard, Discover or American Express cards. Somewhat perplexingly, I have not found analysis relating this decision to an increase in interchange fees until a 2009 US Government Accountability Office report said that Visa officials attributed an increase in Visa's interchange fees to the increased 
competition for issuers that followed this decision. ${ }^{37}$ Evans and Schmalensee (2005a) relate greater competition for issuers to greater competition for cardholders and I argue that merchants facing higher MSFs (because of higher interchange fees) is consistent with an increase in consumer single-homing, which the seminal work of Rochet and Tirole (2003) argues reduces the ability of merchants to influence instrument choices, thereby shifting the pricing structure against them. I refer also to Rysman (2006) who argues that, although consumers often multi-home or have multiple types of cards in their wallet, they generally only use one of those cards (they effectively single-home). Although the exact reasons for why MSFs have risen are not clear, I suggest that, because it allowed banks to issue any combination of the different types of cards (against card networks' wishes), the court decision raised demand-side transaction costs and harmed dynamic efficiency.

\section{Australia's Bankcard}

The examples I have discussed so far suggest that restrictions on payment networks' freedom of contract specifically relating to instruments' provision (that prevent the trading of property rights) do reduce the demand for payment instruments. I have, however, found one example of such a restriction that I argue did not reduce and may have actually increased demand for an instrument. This example means that I argue that restrictions only risk reducing instrument demand. The example, which I first discussed in subsection 4.1.1, involves the 1980 case of an Australian regulator restricting Bankcard participants' ability to enter into contracts that controlled the prices that could be charged to merchants and consumers. If these prices were being set collusively, and my analysis suggests they were, I argue that removing participants' ability to contract

\footnotetext{
37 Some evidence indicated a long term downwards trend in merchant service fees for American Express, suggesting the networks were becoming more similar in terms of their offering to merchants and consumers.
} 
around them would not have reduced instrument demand. In fact, if it caused prices to change, I argue the action may have increased instrument demand.

\subsubsection{Introducing Analysis of Effects of Restrictions on Instrument Supply}

In section 5.3, I argued that, in workably competitive conditions, a payment network will attempt to raise its profits by offering a new instrument that get used while it at least recoups its costs of supply from fees paid by users. I went on to argue that this will cause a process of institutional adaption for profit-seeking networks. Additionally, I argued that (potential) inter-network competition raises the incentive for a profitseeking network to offer an instrument that generally reduces demand-side transaction costs to a greater degree than competing networks' instruments and provide it with lower costs of supply. These arguments suggest there are two ways government restrictions may affect the instrument supply decisions of payment networks. In subsection 5.4.4, I analyse the effects of restrictions on the institutional adaption of profit-seeking payment networks. In subsection 5.4.5, I do the same for restrictions reducing inter-network competition.

\subsubsection{Effect of Restrictions on Institutional Adaption}

In subsection 5.3.2, I argued that an adaptive process is brought on by the relevant private objective for profit-seeking payment networks: in workably competitive conditions, a network will wish to increase its profits by offering an instrument that generally reduces demand-side transaction costs while at least recouping its costs of supply. If government restrictions affect this adaption process, it follows that they will diminish the dynamic efficiency of payment networks. Nevertheless, I analyse each of cases of this occurring below. Except for the final examples that cover an Australian regulators' attempts to introduce institutions without modifying incentives, I also discuss other ways individuals have used or might have used instruments that generally 
reduce demand-side transaction costs and why I believe those attempts have not been or would not be as successful at reducing these costs. That is, I discount the possibility of inter-network competition operating to promote dynamic efficiency.

\section{Government restrictions and the costs of supply}

In this subsection, I analyse a number of examples of system development when government rules meant some firms, such as NBFIs, were restricted from performing certain business activities while others such as banks, were not. This would obviously raise the scarcity value held by the unrestricted firms and make them less willing to cooperate with the restricted firms. I argue that such restrictions result in an increase in the costs for the unrestricted firms of cooperating with restricted firms, which I represent by identifying that restrictions increase the costs of supply of instruments provided by cooperative payment networks.

\section{Debit cards in the US}

Unlike credit cards in the US, debit cards were not significantly developed beyond their first pilot in 1966 until after the development of the POS terminal in the second half of the 1970s, which allowed debit card payments to be completed immediately using a bank's ATM card at a merchant's location. At that time, US banking regulations restricted banks' size by regulating their branch locations. I argue that this raised the costs of supply of debit cards because payment networks needed to consist of a large number of different firms to overcome network effects, meaning a higher level of transaction costs. I argue that such restrictions made the costs of supply of a universal debit card prohibitive. Indeed, the multitude of different ATM networks supported by banks from the mid-1970s until approximately the mid-1980s meant that merchants needed to invest in multiple POS terminals to provide debit card services to all of their customers. In subsection 5.2.3, I argued that merchants needing multiple terminals 
would have decreased their willingness to incur the fixed financial costs to accept debit cards.

A US Supreme Court decision in 1985 that non-bank owned ATMs did not represent bank branches greatly increased the number of ATMs connected to centralised, nonbank owned networks. In turn, this reduced the number of POS terminals merchants needed to service their customers, allowing debit card payment networks in the US to overcome network effects sufficiently for debit card use to increase. Following the Supreme Court decision and the reduction in legal uncertainty, the credit card cooperative structures, Visa and MasterCard, attempted to create a joint venture to introduce the online debit card, the Entrée card, in 1987. However, the attempt was effectively blocked by a number of State Attorneys General and, in its place, Visa and MasterCard came to rely on offline debit cards that used credit card infrastructure and did not require merchants to invest in POS terminals; they did however charge merchants proportional MSFs similar to those charged for credit cards. ${ }^{38}$ The alternative to offline debit card networks are the online 'PIN' debit card services offered by non-bank owned ATM networks.

High costs of supply of new instruments caused by the fragmented structure of the debit card payment system continue to affect the pace of innovation in the US and its process of institutional adaption. In subsection 4.8.3, I reported concerns that had been expressed that the pace of innovation was slow and biased towards improvements that are compatible with the existing infrastructure. Recently, payment networks in the US have been unable to coordinate the introduction of the chip-based, EMV security

38 The large-scale use of Visa and MasterCard's offline debit cards appears to have caused a gradual increase in debit card interchange fees. 
standard. That is in spite of networks in the standard's introduction in the two countries bordering the US, Canada and Mexico, and in all of my other sample countries.

It is conceivable that inter-network competition could operate through payment networks not involving banks offering debit card instruments that better reduce demandside transaction costs. ${ }^{39}$ However, debit cards are an asset specific to bank accounts, raising the issue of transaction costs (as I discussed in subsection 2.3.1, asset specificity is a transaction cost reason that makes an activity more likely to be coordinated within, rather than outside, a firm). Were debit cards offered by organisations other than banks, it is difficult to believe demand-side transaction costs would generally be reduced.

Consistent with this, I observed above that debit cards were not greatly developed in the US prior to the invention of the POS terminal, which allowed debit cardholders to directly access their bank accounts, and evidence from Evans and Schmalensee (2005a) that three-party schemes have not been interested in issuing debit cards in the US. Moreover, I note that debit cards coordinated by organisations other than banks or NBFIs in two of the countries I study, Germany and the US (being the ELV and decoupled debit products, respectively), were only developed following merchants encountering problems with existing debit cards failing to generally reduce demand-side transaction costs.

\section{The Federal Reserve and ACH payments}

Evidence I described in subsection 4.8.2 suggests the Federal Reserve has been underpricing its cheque-clearing services. ${ }^{40}$ In a paper written by a Federal Reserve employee, Shy (2010), calls on the Federal Reserve to raise the fees on other Fed

\footnotetext{
39 While MasterCard and Visa are obviously not banks, they do not in fact issue payment instruments only their member banks do.

40 I note that the Electronic Payments Network does operate an $\mathrm{ACH}$ processing network, but that it does not appear to constrain the prices the Federal Reserve charges for ACH transactions.
} 
services (such as cheque-clearing), while leaving the fee for $\mathrm{ACH}$ transactions

unchanged. If one assumes that $\mathrm{ACH}$ payments are cheaper to process than cheques, this strongly suggests the Federal Reserve is not taking a (socially) profitable opportunity to generally reduce demand-side transaction costs and its dominance in $\mathrm{ACH}$ transaction processing appears to have restricted the ability for other payment networks to take that opportunity.

To an extent, inter-network competition operates through non-bank direct entry systems such as Paypal. Indeed, I argue that the creation and development of Paypal was an attempt to find an alternative way to generally reduce demand-side transaction costs for direct entry transactions. I believe it is unlikely to be fully effective at generally reducing such costs because it requires the maintenance of an account additional to the bank account that absorbs consumers' wages, which, as I argued in subsection 5.2.1, increases its inconvenience for consumers as a payment instrument.

\section{Stored-value cards}

I have found evidence that in Australia, ${ }^{41}$ Germany, ${ }^{42}$ Norway, ${ }^{43}$ and the $\mathrm{UK},{ }^{44}$ legislation was passed that restricted issuers of stored-value instruments. In the case of Germany, legislation appears to specifically require that the issuance of stored-value cards be performed by banks. For the other three countries, legislation has made it significantly more costly to issue stored-value instruments, unless an issuer is already

41 As I discussed in subsection 4.1.2, legislation passed in Australia in 1998 meant issuers of storedvalue instruments are a type of Authorised Deposit Taking Institutions, regulated by Australia's prudential supervisor, the Australian Prudential Regulation Authority.

42 As I discussed in subsection 4.4.3, Germany amended its banking law in 1997 to specify that electronic money issuance was the business of banks, thereby restricting others from performing it, $n$ order to update its financial law with trends in European law.

43 As I discussed in subsection 4.6.3, Norway passed the Act concerning Electronic Money Institutions in 2002 to meet EU Directives with regulations of electronic money issuers to be administered by the Kredittilsynet, the Norwegian Financial Supervisory Authority.

44 As I discussed in subsection 4.7.3, the UK introduced a regulatory framework to meet EU Directives with regulations of electronic money issuers to be administered by the FSA. 
regulated by prudential supervisors, as banks already are. That is, issuance is to some extent restricted to banks. As evidence of the costliness and inefficiency of being regulated in this way, at least in the UK, I point to the somewhat questionable argument accepted by a UK government regulator as to why EU-directed electronic money regulations did not apply to the non-bank issuer, TfL (Transport for London), of the UK stored-value instrument, the Oyster card, which I described in subsection 4.7.3. ${ }^{45}$ This stands at odds with my analysis indicating that public transport represents a promising way of generally reducing demand-side transaction costs for stored-value instruments and that, for transaction cost/asset specificity reasons, a stored-value instrument would better be owned, at least initially, by the owner of the public transport operations. Moreover, the development of Snapper in New Zealand clearly demonstrates that such an instrument can successfully be offered by a public transport operator that is not prudentially supervised. It follows that the regulation of stored-value instruments significantly reduced the profitable opportunities available to payment networks, harming dynamic efficiency.

It is possible that inter-network competition could operate through banks providing stored-value instruments for use on public transport. I have not, however, identified any such attempts that appear to have been successful. Nor has obvious success been experienced when banks issued stored-value instruments in tandem with those issued by public transport operators as occurred in the UK with the Oyster card and Barclays Bank in 2007. It is also informative to consider the possibility of banks issuing storedvalue instruments completely separate from public transport. The German banking system attempted to provide such an instrument when it rolled Geldkarte out nationally

\footnotetext{
45 The argument I label as somewhat questionable is that TfL buys services from different providers and then resells them to passengers so that the UK's electronic money legislation does not apply to it. This argument was accepted by the relevant UK regulator, the FSA.
} 
in 1997, which I described in subsection 4.4.3. In subsection 5.2.4, I argued the development of Germany's Geldkarte stored-value system was, and remains, unlikely to be successful and this is in spite of evidence that the system was "heavily" subsidised. It seems likely that the private costs and benefits faced by the organisations in Germany that decided to introduce Geldkarte did not appropriately reflect the costs and benefits for society of a payment network offering an instrument that generally reduced demandside transaction costs. I argue that this issue is reflected in the fact that the private banks, which are argued to be the pillar of the German banking system with the strongest profit-motive, did not strongly support the rolling out of the Geldkarte instrument.

I argue that more obvious cases of private costs and benefits diverging significantly from social costs and benefits come from analysis of occasions when the Australian and UK Governments appear to have failed to protect the property rights of payment networks.

\section{Profits and property rights - evidence from Australia and the UK}

In subsection 2.3.1, I surveyed literature showing the linkage between property rights and transaction costs (or the costs of supply). Because bargaining between parties is not costless and the incidence of property rights affects the ease of bargaining, it follows that a poor assignment of property rights will affect the profitable opportunities available to payment networks. I have found examples of retail payment system development in two of my sample countries being affected by governments arguably failing to protect the property rights of payment networks.

When an Australian Government review of the country's banking system, the Martin Review Group, recommended that NBFIs be given access to CEMTEX, the banks' 
inter-bank transfer system (an event I discuss in subsection 4.1.1), I argue this was a taking of a property right because it strongly suggested the removal of banks' ability to exclude others from CEMTEX. I also argue that laws that prevented NBFIs from issuing cheques prohibitively raised the costs of supply of instruments provided by networks involving both banks and NBFIs. Indeed, banks appeared to react to the Review Group's recommendation by disbanding CEMTEX, instead exchanging direct entry transaction information bilaterally. This demonstrates that they perceived they were no longer able to use CEMTEX to offer instruments that would be profitable dynamic efficiency was harmed.

Events with CEMTEX occurred at the time that Australian banks were also developing the EFTPOS debit card payment network. At odds with nearly all other debit card systems in my sample countries, the banks argued that a payment network with bilateral interchange agreements was appropriate for this. I argue that, because participants need to negotiate bilateral agreements with every other participant, this framework significantly raised the costs of supply of EFTPOS debit cards. I also argue that internetwork competition was not sufficient to improve the operation of these networks because Australia's NBFIs did not represent a large enough proportion of its financial system to compete with its banks. As I described in subsection 4.1.1, Australian NBFIs did in fact process EFTPOS and direct entry transactions multilaterally through Cashcard Australia Limited and AUSTNET. My argument implies that NBFIs' instruments would have been more successful, had they made up a larger part of Australia's financial system.

Property rights also appear to be an issue for the development of debit card and direct entry payments in the UK. In 1985, banks created a joint-venture to manage a cooperative debit card system, EFTPOS UK, an event that I discuss in subsection 4.7.3. 
The operations of EFTPOS UK suggest that EFTPOS UK's members were not concerned about participation in EFTPOS UK. For example, there was a significant debate regarding EFTPOS UK's use of the (apparently incompatible) DES or RSA encryption algorithms, with the organisation eventually deciding on the latter, in spite of the former being used more internationally and for a debit card network introduced earlier by Barclays Bank, PDQ. If this decision does show a lack of concern about the network's success, I argue that it demonstrates members did not hold appropriate property rights for EFTPOS UK - members did not benefit (sufficiently) from the network's success. I have not, however, found any other evidence of this and it remains a point for further study.

Inter-network competition for EFTPOS UK appears to have been hampered with some evidence pointing to the role of the UK's central bank, the Bank of England in this. A representative of the Bank sat on the board of EFTPOS UK and his or her presence resulted in banks perceiving they had fewer options, but to be involved in EFTPOS UK. ${ }^{46}$ With Barclays Bank leading, banks introduced their own debit card networks (and EFTPOS UK was eventually wound up in 1990). Although three banks cooperated to introduce one of the debit card networks, Switch, the banks were not able to form a fully cooperative network, such as EFTPOS UK would have been. Retailer discomfort regarding the MSFs charged for these services, particularly the proportional MSFs that Barclays Bank proposed to charge, suggests that the networks that followed the demise of EFTPOS UK were less than completely effective at offering instruments that generally reduced demand-side transaction costs. I acknowledge that the UK institution of free in-credit banking for consumers that existed at that time makes it difficult to

46 In subsection 4.7.3, I discussed Howells and Hine (1993) who quote (p. 114) one bank manager as saying, "[t]here's no way somebody like Barclays could stay out of that [EFTPOS UK], even if they wished to stay out of it. I think there would have been a lot of arm-twisting at governmental level, if you like, to persuade a major bank to participate in the new clearing system." 
know how payment networks might have been more effective at generally offering such instruments while recouping their costs of supply.

The Cruickshank government report into the UK's financial system, published in 2000, reported that banks appeared unwilling to invest in innovations improving the transmission of money (which I argue relate to direct entry payment networks). The report blamed the lack of innovation on a lack of competition between those banks. More in keeping with the framework of institutional adaption I have created, however, Ganguly and Milne (2002) blame insufficient incentives for the lack of innovation, which I relate to a lack of profitable opportunities for payment networks, particularly the recoupment of a payment network's costs. Interestingly, they argue that payment instrument innovations are a public good, thereby indicating that such innovations are non-excludable. Although I have not found sufficient evidence to confirm the relationship, I relate the non-excludability of a payment networks to its owners not holding property rights over direct payment networks. Perhaps reflecting this, the Faster Payments payment network, set up to improve on the interbank transfer system, BACS, was not created until following the Cruickshank review and, even then, only with the involvement of a government authority, the Office of Fair Trading. Other than Faster Payments, I have not observed any obvious attempts to use inter-network competition for direct entry payments.

\section{Creating institutions without modifying profitability - evidence from Australia}

On a number of occasions that I discuss in subsection 4.1.4, the regulator of retail payment systems in Australia, the RBA, attempted to encourage the creation of institutions that it perceived as being more efficient that existing institutions. When it did so, however, I argue it made no real attempt to modify the profitability of payment 
networks offering instruments. Using Grief's framework of institutional change, I argue these institutions have not (yet) become self-enforcing.

In 2003, the RBA intervened to regulate interchange fees downwards. In its 2007/2008 review of the effects of its reforms, it appeared to remain concerned that, without its regulation, interchange fees would rise once again. The RBA suggested that its concerns about Australia's credit card retail payment system might be allayed, allowing it to step back from regulation, if networks made voluntary assurances that average interchange fees would not rise beyond current levels. (Such assurances were not forthcoming and, in August 2009, the RBA announced regulation would remain.) I argue that the RBA had not modified, to any significant extent, the incentives faced by credit card networks and a rise in interchange fees was and is likely to occur, following the removal of regulation. Contrary to the RBA, however, I argue that this would be socially beneficial because it would allow payment networks to offer instruments that were more effective at generally reducing demand-side transaction costs while recouping networks' costs of supply.

In an attempt to deal with the RBA's concerns with EFTPOS interchange fees, Australian banks approached Australia's competition regulator in 2002 about modifying the EFTPOS network to end the payment of interchange fees, which the regulator eventually authorised. I argue that no real effort was made to ensure that change would allow the network to offer an instrument that generally reduced demand-side transaction costs. Indeed, it appeared to increase these costs for merchants, relative to the EFTPOS instrument that had been offered before. I argue this was reflected in a group of merchants appealing the competition regulator's authorisation to a review panel, the Australian Competition Tribunal, which upheld the appeal and set aside the regulator's decision. The RBA responded by designating the EFTPOS network and directly 
regulating interchange fees closer to zero. This decision was also appealed by a group of merchants, but this time the appeal was unsuccessful.

In its 2007/08 review, the RBA said a second way that banks might allay its concerns was if banks made enhancements to Australia's EFTPOS network. In 2009, one banking organisation announced the establishment of EFTPOS Payments Australia Limited which would have commercial responsibilities for managing and promoting EFTPOS while another announced it was restarting development of a direct entry payment network, MAMBO. In August 2009, however, the RBA announced that the industry had not made sufficient progress towards its suggestions and regulation would be retained, removing any incentive effect its approach would have had. It is not yet clear what long run influence EFTPOS Payments Australia or MAMBO will have on retail payment system development in Australia.

\subsubsection{Effects of Restrictions on Inter-Network Competition}

In section 5.3, I argued that participation was beneficial for payment networks. In the presence of potential inter-network competition, this means a profit-seeking payment network will likely experience greater participation if, ceteris paribus, it offers an instrument that generally reduces demand-side transaction costs to a greater degree than competing networks' instruments and provides it with lower costs of supply. It follows that restrictions on inter-network competition will reduce the incentive for profitseeking payment networks to offer instruments that generally reduce such costs, harming dynamic efficiency. This argument is supported by analysis of examples from a number of my sample countries.

\section{The Canadian Payments Association}

The passing of the Canadian Payments Association Act in 1980 gave responsibility for (inter-bank) retail payment systems in Canada to the CPA (the Canadian Payments 
Association), causing a substantial reduction in inter-network competition. I argue that this reduced the incentive for networks to offer instruments that generally reduced demand-side transaction costs and I argue two examples of the CPA's instruments reflect this: ${ }^{47}$

- In the period following their 1986 introduction, Interac's shared ATM services included only withdrawals and did not extend to include balance inquiries and ATM deposits and

- In 2007, testimony was made before a House of Commons Standing Committee that bill payments took an excessive amount of time to complete. That testimony led to the publication of a report by the CPA showing up to $80 \%$ of billers elected to operate bill payments outside the CPA's bill payments framework, ${ }^{48}$ demonstrating the framework was not effective for offering instruments that generally reduced demand-side transaction costs.

I argue the legislation that restricted participation in CPA payment networks to CPA members raised the costs of supply for instruments that involved cooperation between members and non-members. The examples above indicate that significant profitable opportunities existed for payment networks to offer instruments that generally reduced demand-side transaction costs. Yet, it appears that prohibitive costs of supply have prevented networks forming that involved cooperation between CPA members and nonmembers. Indeed, in subsection 4.2.3, I observed two occasions that the CPA went as far as to pass rules preventing the creation of networks involving such cooperation:

47 Not long after the creation of the CPA, the CPA's banking members used a similar governance structure to create a debit card and ATM network, Interac. The similarities in the structures, no-less in the behaviour, of both Interac and the CPA means I do not differentiate between them for the purposes of this discussion of inter-network competition.

48 The paper reports that bill payments were instead conducted with other payment instruments, such as cheques, 
- $\quad$ in 2003, the CPA banned members from processing certain telephone-based payments, called tele-cheques and

- $\quad$ in 2005, the CPA required that bill payments be initiated from members' own websites, rather than the websites of third parties.

When taken into account with the evidence of demand-side transaction costs not being generally reduced, it appears the rules were an attempt to prevent members from taking advantage of the profitable opportunities existing for payment networks that would have placed at risk the restrictions CPA members enjoyed. This clearly demonstrates that the creation of the CPA has resulted in a significant reduction in the incentive for instruments to be offered that generally reduce demand-side transaction costs.

\section{Germany's Electronic Cash}

In subsection 4.4.1, I discussed the German banking system, which consists of three pillars, each governed by an association that can issue decisions binding on its members. The three associations provide representatives to a central association, the ZKA (the Zentraler Kreditausschuss) and I conclude that profitable opportunities for payment networks not involving the ZKA, and therefore inter-network competition, would have been substantially reduced. Consistent with the centralised nature of the industry, the German banks chose to centralise the operation of the new credit card payment network giving a jointly-owned company, the GZS (Gesellschaft fur Zahlungssysteme) a monopoly of the processing of their Eurocard transactions in 1982. This was a major concern for retailers, however, and I have found information showing the creation of two retailer-owned credit cards in the time of 1990, making it apparent that demand-side transaction costs were not generally reduced. The ZKA began testing the Electronic Cash debit card system in 1983, although Germany's banks did not succeed in agreeing on a national roll out until 1990. The length of time taken to agree 
on a national roll out might also reflect the lack of inter-network competition Electronic Cash faced.

Merchant concerns about inter-network competition for Electronic Cash were reflected in several ways. Firstly, merchant complaints that they were being forced to purchase terminals from the GZS led to the intervention of the Bundeskartellamt, the Federal Cartel Office, who brought about the creation of an open system that allowed merchants, rather than dealing with the GZS, to obtain terminals and use the services of Netzbetreiber or network operators. Secondly, at the time it was introduced, one retailer responded by introducing the ELV (Elektronisches Lastschrift Verfahren) debit card network, which functioned by using information on Electronic Cash cards to generate direct debits for signature by cardholders and, in spite of not guaranteeing payment to merchants, proved a popular payment instrument in Germany. I argue, however, that these attempts did not appear to provide full inter-network competition for Electronic Cash because the response that resulted in the creation of the Netzbetreiber did not fundamentally change the terms of Electronic Cash and because the second response, ELV, did not operate with a payment guarantee.

\section{Australia's Bankcard}

Evidence I discussed in subsection 4.1.1 indicates that Australia's banks may have acted collusively when they introduced the Bankcard credit card in 1973. NBFIs were not given access to issue Bankcard themselves and an Australian regulator sought the removal of aspects to Bankcard agreements, particularly those that controlled the prices charged to consumers and merchants, in 1980. Australia's banks represented the major portion of Australia's financial system and NBFIs appeared unable to create their own payment network to compete with Bankcard; it was not until the introduction of a Visa debit card in 1982 that NBFIs offered payment cards. If the operations of Bankcard 
were collusive, it demonstrates that the constraints on inter-network competition had reduced the incentive for the Bankcard network to offer an instrument that generally reduced demand-side transaction costs.

\section{Norway's BankAxept}

The majority of the examples I discuss in this subsection suggest restrictions on payment networks' freedom of contract that prevent the trading of property rights do reduce the supply of payment instruments. I have, however, found one example of an action from a government authority that arguably restricted payment networks' freedom of contract, but that I argue did not reduce instrument supply. This example means I argue that restrictions only risk reducing instrument supply. In the mid-1980s, Norway's central bank, Norges Bank, created the Technical Reporting Committee on Payment Systems. I argue that this may have represented a restriction on payment networks' freedom of contract because it potentially, the actions of Norges Bank, would have made it difficult for Norwegian banks to reach agreement to form payment networks not involving the Norges Bank committee. In 1991, however, Norwegian banks reached an agreement to form the BankAxept payment network, which I argue indicates instrument supply was not significantly reduced.

The actions of Norges Bank do, however,continue to create concerns about the state of inter-network competition. In 2008, the Norwegian central bank, Norges Bank, made a press release complaining that some banks were now pricing payment services to consumers free-of-charge. This practice, the release argued, risked reducing investment in payment services and risked the creation of cross-subsidises, which "sends the wrong signal to customers and may result in the inefficient use of resources." I argue that the statement risks reducing inter-network competition because it indicates an instrument 
not charging consumers a per-transaction fee would not be viewed favourably by Norges Bank.

\subsubsection{Summarising the Effect of Government}

In this section, I have shown that governments play two important roles in retail payment system development. Firstly, they define property rights and enforce contracts. Secondly, they can impose restrictions on the freedom of contract for payment networks. When these restrictions prevent the trading of property rights, I have argued that they risk reducing the demand for payment instruments and their supply by payment networks, harming dynamic efficiency. Such restrictions will reduce demand if the payment instrument that would have been used no longer generally reduces demand-side transaction costs. They risk reducing supply in two ways: by impeding payment networks' attempts to offer instruments that reduce these transaction costs or by reducing inter-network competition. In summary, government restrictions on the freedom of contract have had a substantial negative effect on the development of retail payment systems. 


\section{Chapter 6}

\section{Conclusion}

In this thesis, I have created a framework I believe has not been seen in the literature before that aids the understanding of the development of retail payment systems. My framework yields insights into the incentives of (potential) users of payment instruments and of the payment networks that provide them. Additionally, it provides a means to assess the role of government in the evolution of retail payment systems.

At the beginning of this thesis, I stated that I sought an answer to the question, how have institutional arrangements affected the development of the retail payment systems that have emerged since the creation of Diner's Club in 1949? The framework I created to help answer this question utilises demand-side transaction costs to explain aspects of the demand of payment instruments and their supply by the payment networks that are part of a retail payment system. I showed that government restrictions on payment networks' freedom of contract that prevent the trading of property rights risk reducing the demand or the supply of payment instruments. I find that it is government restrictions on the freedom of contract that are the substantial cause of differences in the use of newly-developed retail payment systems between my sample countries. This finding suggests a partial answer to my research question: it is government restrictions on freedom of contract that are a key influence on the development of the retail payment systems. Such restrictions risk reducing the supply and demand of retail payment systems, diminishing innovation in payments and thereby harming dynamic efficiency.

In addition to the historical events discussed in this thesis, there will be many other important aspects to retail payment system development that I have not analysed in detail. Although the framework developed here may prove useful for answering them, 
many important research questions will remain. Included in those will be questions relating to two specific areas I identified. I have been unable to explain why Germany is a significant outlier in terms of credit and debit card transaction volume in the countries in my sample and I have been unable to document why perceptions of property rights for retail payment systems appear to be such an issue for their development in the UK. In addition, I have identified a number of countries/regions suitable for further analysis:

- I lacked sufficient information on retail payment systems in Iceland, which I calculated to have 330 debit and credit card transactions per capita during 2008, well above New Zealand's 241 and Norway's 228 transactions

- In section 4.3, I argued that a full exploration of the influence of the European Union on retail payment system development in its member countries was beyond the scope of this thesis and

- In section 2.1, I mentioned the success of mobile phone-based systems in a number of developing countries, and Korea and Japan, but argued that it was beyond the scope of my thesis and I did not fully consider evidence on these. 


\section{Bibliography for Main Body of Work ${ }^{1}$}

Ackerberg, D. and Gowrisankaran, G. (2006). Quantifying equilibrium network externalities in the ACH banking industry. The RAND journal of economics, Autumn, 37(3), 738-761

Amromin, G. and Chakravorti, S. (2009). Whither loose change? The diminishing demand for small-denomination currency. Journal of money, credit and banking, 41(23), 315-335

Anderson, R. and Rivard, B. (1999). Antitrust policy towards EFT networks: the Canadian experience in the Interac case. Antitrust law journal, 67(2), 389-452

Arango, C. and Taylor, V. (2008). Merchant acceptance, costs, and perceptions of retail payments: a Canadian survey. Bank of Canada discussion paper, 2008-12

Australian Payments Clearing Association. (2009). 2009 annual review, Sydney: Australian Payment Clearing Association, Retrieved from http://www.apca.com.au/AR2009/pdf/apca_2009_annual_review.pdf

Bakos, J. and Nault, B. (1997). Ownership and investment in electronic networks. Information systems research, 8(4), December

Bátiz-Lazo, B. (2009). Emergence and evolution of ATM networks in the UK, 19672000. Business history, 51(1), 1 - 27

Baxter, W. (1983). Bank interchange of transactional paper: legal and economic perspectives. Journal of law and economics, 26(3), 541-588, Retrieved from http://idei.fr/doc/conf/tsm/payment_card_review1.pdf

Board of Governors of the Federal Reserve System. (2010, December 16). Debit card interchange fees and routing, notice of proposed rulemaking. Retrieved from http://www.federalreserve.gov/boarddocs/meetings/2010/20101216/20101216_Intercha ngeFeeProposedRuleDRAFTFRNotice.pdf

Bolt, W.; Humphrey, D. and Uittenbogaarda, R. (2008). Transaction pricing and the adoption of electronic payments: a cross-country comparison. International journal of central banking, 4(1), 89-123

Bolt, W., Jonker, N. and van Renselaar, C. (2009). Incentives at the counter: an empirical analysis of surcharging card payments and payment behaviour in the Netherlands. Journal of banking and finance, forthcoming, 8 September 2009

Borzekowski, R., Kiser, E. K. and Ahmed, S. (2008). Consumers' use of debit cards: patterns, preferences, and price response. Journal of money, credit and banking, 40(1), 149-172

1 References used for Chapters 3 and 4 are summarised not in this bibliography, but in the bibliographies that appear at the end of each section in Chapter 4. 
Bradford, T. and Hayashi, F. (2007). Complex landscapes: mobile payments in Japan, Korea and the United States. Payments system research briefing. September, Federal Reserve Bank of Kansas City

Capie, F. (2007). Some historical perspective on financial regulation. In D. Mayes and G. Wood (Eds.). The structure of financial regulation, 69-85, New York: Routledge

Carletti, E. and Hartmann, P. (2002). Competition and stability: What's special about banking? European Central Bank working paper series, No. 146

Chakravorti, S. (2000). Why has stored value not caught on? Emerging issues series, Federal Reserve Bank of Chicago

Chakravorti, S. and Roson, R. (2004). Platform competition in two-sided markets: The case of payment networks. Federal Reserve Bank of Chicago working papers, WP 200409

Cheung, S. (1968). Private property rights and sharecropping. The journal of political economy, 76(6), 1107-1122

Cheung, S. (1969). Transaction costs, risk aversion, and the choice of contractual arrangements. Journal of law and economics, 12(1), 23-42

Ching, A. (2010). Consumer learning and heterogeneity: dynamics of demand for prescription drugs after patent expiration. International journal of industrial organization, 28, 619-638

Claessens, S. and Laeven, L. (2004). What drives bank competition? Some international evidence. Journal of money, credit, and banking, 36(3), 563-583

Coase, R. (1937). The nature of the firm. Economica, 4(16), 386-405

Coase, R. (1960). The problem of social cost. Journal of law and economics, 3, 1-44

Coase, R. (1988). The nature of the firm: Meaning. Journal of law, economics, \& organization, 4(1), 19-32

Committee on Payment and Settlement Systems [CPSS]. (2003). A glossary of terms used in payments and settlement systems. Bank of International Settlements, March, Retrieved from http://www.bis.org/publ/cpss00b.htm

Cruickshank, D. (2000). Competition in UK banking: A report to the Chancellor of the Exchequer, Norwich: Her Majesty's Stationery Office, Retrieved from http://www.hmtreasury.gov.uk/fin_bank_review.htm

Dahlman, C. (1979). The problem of externality. Journal of law and economics, 22(1), 141-162.

Davies, R. and Davies, G. (1999). A comparative chronology of money: monetary history from ancient times to the present day, Retrieved from http://projects.exeter.ac.uk/RDavies/arian/amser/chrono1.html

Deungoue, S. (2008). Will we pay in the same way? European journal of finance, 14(1), 49-67 
Dick, A. (2007). Market size, service quality and competition in banking. Journal of money, credit and banking, 39(1), February

Electronic Payments Network. (2004). The Electronic Payments Network and the ACH: A history, Retrieved from http://ezpay.org/cms/documents/001743.pdf

Emch, E. and Thompson, T. (2006). Market definition and market power in payment card networks. Review of network economics, 5(1)

Epstein, R. (2005). The regulation of interchange fees: Australian fine-tuning gone awry. Columbia business law review, 3, 551-597

European Central Bank. (2008). Glossary of terms related to payment, clearing and settlement systems, 30 September, Retrieved from http://www.ecb.int/paym/cons/shared/files/glossarypaymentclearingsettlementsystems.p df?64c737f2266fa45376af9d3127bacb59

Evans, D. (2003). Some empirical aspects of multi-sided platform industries. Review of network economics, 2(3)

Evans, D. (2008). Two-sided market definition. Forthcoming in ABA section of Antitrust Law, Market definition in antitrust: Theory and case studies, October

Evans, L. and Hahn, R. (2010). Regulating dynamic markets: Progress in theory and practice. New Zealand Institute for the Study of Competition and Regulation, Retrieved from at: http://ssrn.com/abstract=1646957

Evans, D. S. and Schmalensee, R. (2005a). Paying with plastic: The digital revolution in buying and borrowing, Second Edition, Massachusetts: The MIT Press

Evans, D. and Schmalensee, R. (2005b). The economics of interchange fees and their regulation: An overview. MIT Sloan Working Paper in Interchange fees in credit and debit card industries, Kansas City: Federal Reserve Bank of Kansas City, 73-120

Federal Financial Institutions Examination Council. (2004). IT examination handbook, retail payment systems booklet, Retrieved from http://www.ffiec.gov/ffiecinfobase/booklets/Retail/retail.pdf

Frankel, A. and Shampine, A. (2006). Economic effects of interchange fees. Antitrust law journal, 73, pp. 627-673

Ganguly, B. and Milne, A. (2002). Retail payment systems in the UK: is there a lack of competition?, published in Pringle, R. and Robinson, M, (eds) E-money and Payment Systems Review, Central Banking Publications

Garcia-Swartz, D., Hahn, R. and Layne-Farrar, A. (2006). The move toward a cashless society: a closer look at payment instrument economics, Review of network economics, 5(2), 175-198.

Garcia-Swartz, D., Hahn, R. and Layne-Farrar, A. (2007). Further Thoughts on the Cashless Society: A Reply to Dr. Shampine. Review of network economics, 6(4), 509524 
Goodhart, C. (2007). Financial supervision from an historical perspective. In D. Mayes and G. Wood (Eds.). The structure of financial regulation, 43-64, New York: Routledge

Guariglia, A. and Loke, Y. (2004). What determines the value and volume of noncash transactions? Evidence from a panel of European and North American countries. Applied economics, 36(4), 291 - 303

Greif, A. (2006) Institutions and the Path to the Modern Economy: Lessons from Medieval Trade, New York: Cambridge University Press

Guerin-Calvert, M. and Ordover, J. (2005). Merchant benefits and public policy towards interchange: An economic assessment. Review of network economics, 4(4)

Guibourg, G. (2001) Interoperability and network externalities in electronic payments. Sveriges Riksbank working paper series, 126, September

Hayashi, F., Sullivan, R. and Weiner, S. (2003). A guide to the ATM and debit card industry. Payments System Research Department, Federal Reserve Bank of Kansas City

Hayashi, F. and Weiner, S. (2006). Interchange fees in Australia, the UK, and the United States: Matching theory and practice. Economic review, Federal Reserve Bank of Kansas, Third Quarter

Heikkinen, Päivi (2007) "Regulating the payment card industry", BoF Online, Bank of Finland, Bank of Finland: Financial Markets and Statistics, 22 May

Heritage Foundation. (2010). Index of economic freedom 2010, retrieved from http://www.heritage.org/index/

Howells, J. and Hine, J. (eds) (1993). Innovative banking: Competition and the management of new networks technology, London: Routlege

Humphrey, D., Pulley, L. and Vesala, J. (1996). Cash, paper, and electronic payments: a cross-country analysis. Journal of money, credit and banking, 28(4), Part 2: Payment Systems, 914-939

Ives, B. and Earl, M. (1997). Mondex International: Reengineering money, London Business School CRIM CS97/2, Retrieved on March 5, 2011 from http://wings.buffalo.edu/academic/department/som/isinterface/is_syllabus/mondex/mon dex.html

Jack, W. and Suri, T. (2010, August). The economics of M-PESA. MIT Sloan working paper, available: http://www.mit.edu/ tavneet/M-PESA.pdf

Kasper, W. and Streit, M. (1998). Institutional economics: Social order and public policy, the Locke Institute, Cheltenham: Edward Elgar Publishing

Katz, M. (2005). What do we know about interchange fees and what does it mean for public policy? Commentary on Evans and Schmalensee. Proceedings - Payments System Research Conferences, Federal Reserve Bank of Kansas City, May

Katz, M. and Shapiro, C. (1994). Systems competition and network effects. The Journal of Economic Perspectives, 8(2), Spring, 93-115 
Kemppainen, K. (2003). Competition and regulation in European retail payment systems. Bank of Finland discussion papers, 16

Kemppainen, K. and Salo, S. (2006). Promoting integration of European retail payment systems: Role of competition, cooperation and regulation. SUERF Studies, presented at SUERF Seminar, Malta, Retrieved from http://www.suomenpankki.fi/NR/rdonlyres/5122D7E9-45D9-4436-9CFB587FA78F1797/0/SUERF_2006_Kemppainen_Salo.pdf

Khiaonarong, T. (2003). Payment systems efficiency, policy approaches, and the role of the central bank", Bank of Finland discussion papers, 1

Kitch, E. (1990). The framing hypothesis: Is it supported by credit card issuer opposition to a surcharge on a cash price? Journal of law, economics, \& organization, 6(1), Spring, 217-233

Klee, E. (2006). Families' use of payment instruments during a decade of change in the U.S. payment system. Finance and economics discussion paper, No. 2006-01, Board of Governors of the Federal Reserve System

Kravis, I. and Lipsey, R. (1982). Towards an explanation of national price levels. National Bureau of Economic Research working paper, No. 1034

Lee, J. and Kwon, K. (2002). Consumers' use of credit cards: Some credit card usage as an alternative payment and financing medium. The journal of consumer affairs, 36(2)

Liebowitz, S. and Margolis, S. (1994). Network externality: an uncommon tragedy. Journal of economic perspectives, 8(2), 133-150

Mann, R. J. (2002) Credit cards and debit cards in the United States and Japan. Vanderbilt law review, 55(4), May, 1055 - 1108

Mayes, D. (2006). The future of financial markets, New York: Palgrave Macmillan

Milgrom, P. and Roberts, J. (1992). Economics, organisation and management, New Jersey: Prentice-Hall

Monnet, C. and Roberds, W. (2007). Optimal pricing of payment services when cash is an alternative. Federal Reserve Bank of Philadelphia working paper, No. 07-26

Motta, M. (2004). Competition policy: Theory and practice, Cambridge: Cambridge University Press

Negrin, Jose L. (2005). The regulation of payment cards: The Mexican experience. Review of network economics, 4(4), December

Nyaoma, G. (2009). Regulating mobile money: The case of M-Pesa in Kenya, Draft slides for presentation, 2009, September 16, Retrieved from http://www.afi-global.org

Reserve Bank of Australia. (2004, October 14). Reasons for the decision to designate the EFTPOS payment system, Retrieved from http://www.rba.gov.au/paymentssystem/reforms/debit-card-systems/eftpos-decision.html 
Reserve Bank of Australia. (2007). Reform of Australia's payments system: Issues for the 2007/08 Review, Retrieved from http://www.rba.gov.au/payments-

system/reforms/review-card-reforms/pdf/review-0708-issues.pdf

Reserve Bank of Australia. (2008). Preliminary conclusions of the 2007/08 review, April, Retrieved from http://www.rba.gov.au/payments-system/reforms/review-cardreforms/pdf/review-0708-pre-conclusions.pdf

Reserve Bank of Australia and Australian Competition and Consumer Commission [the Joint Study]. (2000, October). Debit and credit card schemes in Australia: A study of interchange fees and access, Sydney: Reserve Bank of Australia, Retrieved from http://www.rba.gov.au/payments-system/resources/publications/payments-au/interchgfees-study.pdf

Reserve Bank of New Zealand. (2003). Payment and settlement systems in New Zealand, September, retrieved from http://www.rbnz.govt.nz/finstab/payment/3236268.pdf

Rochet, J. and Tirole, J. (2003). Platform competition in two-sided markets. Journal of the European Economic Association, 1(4), June, 990-1029

Rochet, J. and Tirole, J. (2006a). Two-sided markets: A progress report. RAND Journal of Economics, 37(3), Autumn, 645-667

Rochet, J. and Tirole, J. (2006b). Externalities and regulation in card payment systems. Review of network economics, 5(1)

Rochet, J. and Tirole, J. (2008). Tying in two-sided markets and the Honor All Cards Rule. International journal of industrial organization, 26, 1333-1347

Rosen, S. (1974). Hedonic prices and implicit markets: Product differentiation in pure competition. The journal of political economy, 82(1), 34-55

Rysman, M. (2006). An empirical analysis of payment card usage. Department of Economics working papers series, WP2006-002, Boston University

Scholnick, B.; Massoud, N.; Saunders, A.; Carbo-Valverde, S. and RodriguezFernandez, F. (2008). The economics of credit cards, debit cards and ATMs: a survey and some new evidence. Journal of banking \& finance, 32(8), 1468-1483

Schreft, S. (2006). How and why do consumers choose their payment methods? The Federal Reserve Bank of Kansas City research working papers, RWP 06-04, April

Sedlabanki Islands [central bank of Iceland]. (2010). Payment Intermediation Time Series Data, Retrieved on April 29, 2010 from http://www.sedlabanki.is/?pageid=552\&itemid=a87b93ae-9862-43f4-afb5be328588d7f5\&nextday $=13 \&$ nextmonth $=4$

Semeraro, S. (2009) The Reverse-Robin-Hood-Cross-Subsidy Hypothesis: Do credit card systems tax the poor and reward the rich? Rutgers law journal, Vol. 40, 419-450

Shampine, A. (2007). Another look at payment instrument economics. Review of network economics, 6(4) 
Shy, O. (2010) Person-to-person electronic funds transfers: Recent developments and policy issues. Federal Reserve Bank of Boston public policy discussion papers, No.10-1

Shy, O. and Wang, Z. (2008). Why do card issuers charge proportional fees? Federal Reserve Bank of Kansas City research working paper, 08-13

Small, J. and Wright, J. (2002). The bilateral negotiation of interchange fees in payment schemes. University of Auckland working paper, Retrieved from http://profile.nus.edu.sg/fass/ecsjkdw/setting_interchange_2002.pdf

Snellman, J., Vesala, J. and Humphrey D. (2001). Substitution of non-cash payment instruments for cash in Europe. Journal of financial services research, 19(2)

Stearns, D. (2007). "Think of it as Money": A history of the Visa payment system 19701984, Doctoral dissertation. University of Edinburgh, Retrieved from http://www.era.lib.ed.ac.uk/bitstream/1842/2672/1/Stearns\%20DL\%20thesis\%2007.pdf

Stigler, G. (1972). The law and economics of public policy: a plea to the scholars. The journal of legal studies, 1(1), 1-12

Trebilcock, M. (1993). The limits of freedom of contract. Cambridge: Harvard University Press

United States Government Accountability Office. (2009). Credit Cards: Rising Interchange Fees Have Increased Costs for Merchants, but Options for Reducing Fees Pose Challenges, Report to Congressional Addressees, Retrieved on November 262009 from http://www.gao.gov/new.items/d1045.pdf

Van Hove, L. (2004). Electronic purses in Euroland: Why do penetration and usage rates differ SUERF Studies, No. 2004/4, available: http://ssrn.com/abstract=575821

Van Hove, L. (2006). What future for electronic purses? in Lammer, T. Handbuch EMoney, E-Payment \& M-Payment, Physica-Verlag HD,379-405

Viscusi, K.; Vernon, J. and Harrington, J. (1995). Economics of regulation and antitrust. Second edition, Cambridge: The MIT Press

Weiner, S. and Wright, J. (2005). Interchange fees in various countries: Developments and determinants. Review of network economics, 4(4)

White, L. (2006). Market definition and market power in payment card networks: Some comments and considerations", Review of network economics, 5(1), March

Wilkinson, B. (2008) A primer on property rights, takings and compensation. Wellington: New Zealand Business Roundtable

Williamson, K. (2009, July 9). Police look into bus drivers' fare thefts. Dominion post

Williamson, O. (1979). Transaction-cost economics: The governance of contractual relations. Journal of law and economics, 22(2), 233-261

Williamson, O. (1985). The economic institutions of capitalism: firms, markets, relational contracting, New York: The Free Press 
Wright, J. (2003). Optimal card payment systems, European economic review, 47, 587612

Wright, J. (2004). One-sided logic in two-sided markets. Review of network economics, 3(1), March

Yang, B. and Ching, A. (2009). Dynamics of consumer adoption of new technology: The case of ATM cards. mimeo, University of Toronto

Zinman, J. (2009). Debit or credit? Journal of banking and finance, 33(2), February, 358-366 